\title{
Engaging with risks : citizens, science and policy in mobile phone mast siting controversies
}

Citation for published version (APA):

Hermans, M. A. (2015). Engaging with risks : citizens, science and policy in mobile phone mast siting controversies. [Doctoral Thesis, Maastricht University]. Maastricht University. https://doi.org/10.26481/dis.20150206mh

Document status and date:

Published: 01/01/2015

DOI:

10.26481/dis.20150206mh

Document Version:

Publisher's PDF, also known as Version of record

\section{Please check the document version of this publication:}

- A submitted manuscript is the version of the article upon submission and before peer-review. There can be important differences between the submitted version and the official published version of record.

People interested in the research are advised to contact the author for the final version of the publication, or visit the DOI to the publisher's website.

- The final author version and the galley proof are versions of the publication after peer review.

- The final published version features the final layout of the paper including the volume, issue and page numbers.

Link to publication

\footnotetext{
General rights rights.

- You may freely distribute the URL identifying the publication in the public portal. please follow below link for the End User Agreement:

www.umlib.nl/taverne-license

Take down policy

If you believe that this document breaches copyright please contact us at:

repository@maastrichtuniversity.nl

providing details and we will investigate your claim.
}

Copyright and moral rights for the publications made accessible in the public portal are retained by the authors and/or other copyright owners and it is a condition of accessing publications that users recognise and abide by the legal requirements associated with these

- Users may download and print one copy of any publication from the public portal for the purpose of private study or research.

- You may not further distribute the material or use it for any profit-making activity or commercial gain

If the publication is distributed under the terms of Article $25 \mathrm{fa}$ of the Dutch Copyright Act, indicated by the "Taverne" license above, 


\section{ENGAGING with RISKS}

citizens, science and policy in

mobile phone mast siting controversies

Marijke Hermans

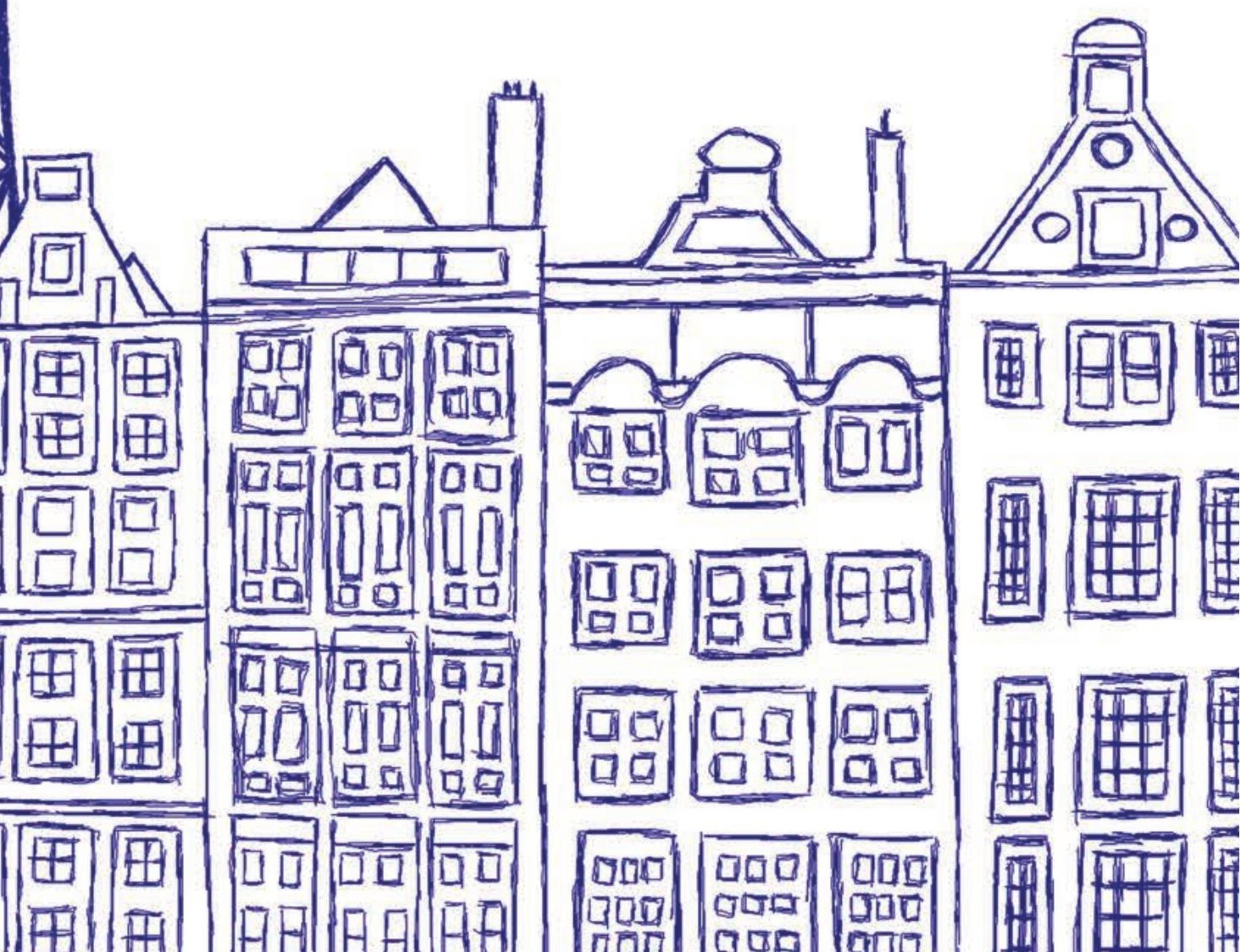


(C) 2015, Marijke Hermans | Alle rechten voorbehouden. Niets uit deze uitgave mag worden verveelvoudigd, opgeslagen in een geautomatiseerd gegevensbestand of openbaar gemaakt worden in enige vorm of op enige wijze, hetzij elektronisch, mechanisch of door fotokopieën, opname, of op enige andere manier, zonder voorafgaande schriftelijke toestemming van de auteur (of optioneel: de uitgever).

(C) 2015, Marijke Hermans | All rights reserved. No part of this publication may be reproduced, stored in a retrieval system, or transmitted, in any form or by any means, electronic, mechanical, photocopying, recording, or otherwise, without the prior permission in writing from the proprietor(s).

Cover design: Noortje Bruyninckx | www.noortjebruyninckx.be Printed \& Lay out by: Datawyse Maastricht

The printing of this dissertation has been financially supported by the Netherlands Graduate Research School for Science, Technology and Modern Culture (WTMC). 


\title{
Engaging with risks \\ Citizens, science and policy in \\ mobile phone mast siting controversies
}

\author{
PROEFSCHRIFT \\ ter verkrijging van de graad van doctor aan de Universiteit Maastricht, \\ op gezag van de Rector Magnificus, Prof. dr. L.L.G. Soete \\ volgens het besluit van het College van Decanen, \\ in het openbaar te verdedigen op vrijdag 6 februari 2015 om 10.00 uur
}

door

MARIJKE AUGUST HERMANS 


\section{Promotores}

Prof. dr ir. M.B.A. van Asselt

Prof. dr. W.F. Passchier

\section{Beoordelingsommissie}

Prof. dr. H. van Lente (voorzitter)

Prof. dr. K. Horstman

Prof. dr. ir. E. Lebret (Rijksinstituut voor Volksgezondheid en Milieu)

Dr. R. Meertens

Prof. dr. J. Petts (University of Southampton) 


\section{Contents}

Woord vooraf

Chapter 1 Introduction 9

An episode from Star Wars $\quad 11$

Setting the scene $\quad 12$

Case of mobile telephony $\quad 17$

Mast siting controversies $\quad 19$

Engaging with risks $\quad 23$

$\begin{array}{ll}\text { Research questions } & 26\end{array}$

$\begin{array}{ll}\text { Constructing health risks } & 27\end{array}$

$\begin{array}{ll}\text { Structure } & 31\end{array}$

$\begin{array}{ll}\text { The research } & 32\end{array}$

Chapter 2 Exploring wireless communication technology as a risk issue 41

Introduction $\quad 42$

Citizens \& EMF 43

Policymakers' response to EMF $\quad 54$

Conclusion and discussion $\quad 60$

My research focus in the light of the review $\quad 61$

Chapter $3 \quad$ Citizen engagement around mast siting 63

Introduction $\quad 65$

$\begin{array}{ll}\text { Early engagement } & 66\end{array}$

$\begin{array}{ll}\text { Collective engagement } & 71\end{array}$

$\begin{array}{ll}\text { Knowledge gathering } & 77\end{array}$

The argument of 'health risks'

Uncertainty and pleas for precaution $\quad 89$

The argument of 'health risks': a blind alley 96

Discussion: understanding citizen engagement in mast siting 98

$\begin{array}{lll}\text { Chapter } 4 & \text { The politics of mast siting } & 109\end{array}$

$\begin{array}{ll}\text { Introduction } & 110\end{array}$

Wireless communication technology in the public arena $\quad 111$

Wireless communication technology in the expert arena 115

Wireless communication technology in the policy arena 117

Wireless communication technology in the local policy arena 119 
Wireless communication in the industry arena

From technology push to national antenna policy

Trickling down the antenna policy

Information sessions as crucial dynamic in siting controversy

Conclusion

Chapter 5 The role of science in the antenna policy

Introduction

Science for policy

The presumed deficit of scientific knowledge

The misguided belief in science as a solution to mast siting controversies

The presumed deficit of information

Conclusion

Chapter 6 Conclusion

Engaging with siting controversies

The dynamics of citizen engagement

Governance approach to mast siting

The dynamics of controversies around technologies

Concluding remarks: moving beyond risk

Appendix 1: Overview of case studies

Appendix 2: Data collection

Appendix 3: Interview protocol case studies

Appendix 4: Atlas.ti coding scheme

Bibliography

Nederlandse samenvatting

Valorisatie 


\section{Woord vooraf}

Eindelijk is het zover! Nu ik het eindpunt heb bereikt, is het tijd om even stil te staan, terug te kijken en een ieder te bedanken die dit boek mogelijk heeft gemaakt.

Toen ik vijf jaar geleden begon aan mijn promotieonderzoek werd ik weleens geconfronteerd met (lichte) desinteresse bij mijn gesprekspartners in mijn onderwerp. Of zoals een gemeentelijke beleidsmedewerker die ik interviewde tegen me zei: "eigenlijk zijn die masten helemaal niet zo spannend ... uiteindelijk is het ook maar gewoon een metalen stok van een meter of twintig tot 40 hoog die neergezet wordt, waar ze een antennetje in hangen". Maar hoe meer ik sprak met burgers die zich inzetten om de plaatsing van zo'n mast tegen te gaan, en hoe meer ik me verdiepte in de beleidsprocessen rondom mobiele telefonie, hoe meer ik erachter kwam dat deze hele problematiek niet ging over 'een metalen stok' maar over de hedendaagse rol van actieve burgers, de omgang met onzekere wetenschap en de legitimiteit van beleidsbeslissingen - zaken die eigenlijk gaan over hoe we onze democratie willen inrichten. Als eerste wil ik dan ook alle mensen die betrokken waren bij een mastcontroverse bedanken om me te woord te staan, soms urenlang, altijd enthousiast en behulpvaardig. Ik ben op vele mooie plekken geweest in de lage landen, bij mensen thuis, in gemeentehuizen en in onderzoekscentra. Ik denk met veel plezier terug aan al die ontmoetingen.

Ik bedank mijn promotoren, Marjolein van Asselt en Wim Passchier, voor het vertrouwen dat ze in me gesteld hebben. Ik was gezegend met twee begeleiders die me de vrijheid gaven mijn eigen koers te bepalen, maar ook aanvoelden welke sturing op welk moment nodig was. Marjolein, ik bedank je in het bijzonder om me mee op sleeptouw te nemen of me op pad te sturen om alle aspecten van het academische leven te verkennen. Wim, bedankt voor het delen van al je kennis en expertise, je geduld en je doortastendheid. Ik voel me vereerd dat ik je laatste promovenda mocht zijn. Ook bedank ik Ragna Zeiss, mijn co-promotor in de eerste twee jaar van mijn promotieonderzoek, voor al haar waardevolle feedback.

Er zijn een hele hoop mensen die me hebben helpen groeien als jonge academicus. Ik wil mijn (oud-)collega's bij FASoS bedanken en in het bijzonder alle mensen van de vakgroep MWT en de onderzoeksgroep MUST. Sabine, Jacqueline en Dianne, bedankt voor jullie professionele en secretariële ondersteuning. Ook dank ik de onderzoeksschool WTMC en in het bijzonder de coördinatoren Willem Halffman en Teun Zuiderent-Jerak, alsook de FASoS Graduate School. De basis voor mijn keuze om te promoveren werd gelegd in de onderzoeksmaster CAST. Daarom bedank ik Wiebe Bijker en Erik Millstone. Ik heb ook veel te danken aan mijn BKO-coach Jessica Mesman en aan Frederic Bouder. 
Ik ben de laatste jaren als promovendus slimmer geworden, maar nog belangrijker is dat ik als mens wijzer ben geworden. Voor deze persoonlijke ontwikkeling zijn een aantal mensen onontbeerlijk geweest. Marijke Heemskerk heeft me in de beginperiode van mijn promotietraject in contact gebracht met yoga. Een nieuwe wereld ging open. Dankzij Marga Sleijser ontdekte ik mijn eigen wijsheden. De geweldige docenten bij HealthWorks fitness club in Cambridge hebben me doorheen mijn laatste schrijfjaar geholpen. Amy (in Cambrigde) en Iris (in Maastricht) slaagden er altijd in de nodige stress uit mijn lichaam te masseren. Het beste medicijn tegen de onderzoeksblues bleek dansen te zijn: bodyjammen of charleston dansen met de immer positieve Sabine (danke schön!) en mijn dansbuddy Véronique. Merci meid voor al onze dansavonturen!

Nog een speciale dank aan al mijn vrienden. Liefste Bianca, je hebt me door dik en dun gesteund, alle ups en downs meegekregen. It means the world to me! Katrien, Lotte en Claudia, wat ben ik trots op onze langdurige vriendschap, die ondanks alle drukte van verbouwingen, trouwerijen, bevallingen en promoties toch stand houdt. My CASTbuddies Constance, Koen, Livia and Julia, thank you for being there to symphatise, laugh, drink, sing and dance together! My DD-ladies Eefje and Anna, thanks for learning me the meaning of ogling, a much-appreciated distraction from PhD work. Thanks, Rike, for making my US experience a little bit more European! My colleagues of the Cbuilding, Natasja and Karlijn and office C.0.12 in particular (the coziest office around), Claudia, Ilse, Maarten, Barbara and (for a very short time) Joan, what a wonderful time we've had, thank you! Claudia, my work buddy, and now my paranymph, having you on my side (literally!) helped me so much. Tessa, mijn paranimf, sinds die eerste ontmoeting bij $\mathrm{CL}$ hebben we samen veel meegemaakt. Wat bof ik met zo'n vriendin als collega.

Ik heb het grote geluk ouders te hebben die me altijd gesteund hebben in al mijn wilde plannen. Ik mocht studeren wat ik interessant vond, zo lang ik wilde en zelfs de vele verhuizingen van het ene kot naar het andere in binnen- en buitenland waren geen punt. Als ik iets echt wilde, zou het ook lukken. Dat hebben mijn ouders mij geleerd. Zonder hun aanmoediging zou dit boek nooit geschreven zijn. Bedankt mama en papa! Joris en Niki en mijn allerliefste neefjes, bedankt voor de nodige afleiding en de ontspannende momenten. Joris, ik ben er zelfs in geslaagd om Star Wars een plekje te geven in mijn boek. Als dat geen reden is om trots te zijn op uw kleine zus! Lode, Rina, Noortje en Robby, bedankt voor jullie onvoorwaardelijke steun, advies en vooral de gezelligheid en familietradities die we intussen al bijna tien jaar delen.

Samen studeren. Samen promoveren. Samen het leven delen. Zo simpel en mooi kan het zijn. Merci, lieve Joeri, voor alles. 
CHAPTER 1

Introduction 


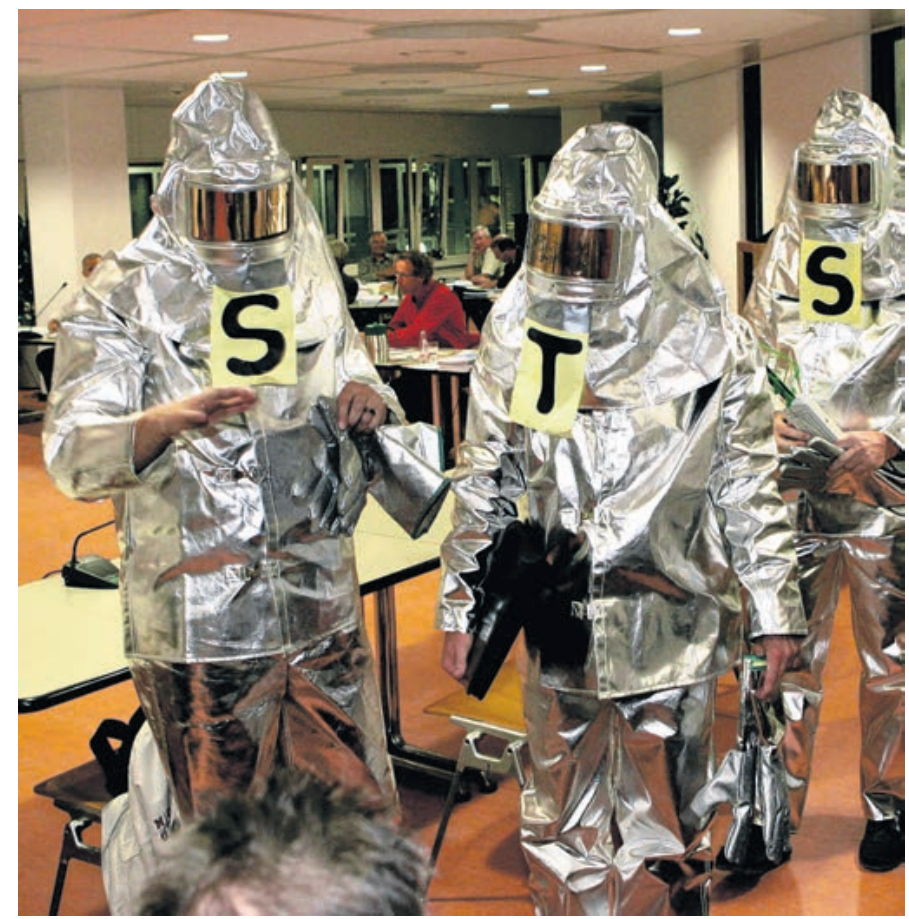

Picture 1.1. - Three members of 'Spijkenisse against Radiation' (StS). Photograph by Algemeen Dagblad. 


\section{An episode from Star Wars}

When three men from 'Spijkenisse tegen Straling' (StS, 'Spijkenisse against Radiation') entered the council chamber in their shiny protective suits in October 2005, many councillors of the city of Spijkenisse, the Netherlands, laughed. StS was there to present the results of their own investigation into health complaints due to exposure to radiofrequency electromagnetic fields (RF EMF) - or 'radiation' as they prefer to call it ${ }^{1}$ - from antennas for wireless communication. The men had orchestrated their entry with dramatic effect. They had changed their clothes for suits and helmets in the toilets, where nobody could see them. When called in, not only did they catch the councillors by surprise, but they also presented the invited press with a great story. "It looked fantastic!", one of them said (Interview S1). ${ }^{2}$ The next day already, the local papers had picked up on their stunt: "the municipality looked like an episode from Star Wars" (n.a., 2005a).

Three close neighbours had founded StS only a few months earlier. News had reached one of them that the municipality and a mobile phone operator planned the siting of a 15-meter high mast for UMTS-antennas in the park close to their homes. Upon returning empty-handed from inquiries with the municipality, he had turned to the Internet: "searching the Internet, I started to worry. Is this radiation healthy at all?" (Abels, 2006). Going from door to door, the neighbours began to share their worries and suspicions with the community. By the time the municipality organised an information meeting, the community centre was filled to the brim and the atmosphere was tense. Unsatisfied by the assurances of the municipality and the telecom operator that the mast needed to be placed in that particular spot, the neighbours of StS took matters into their own hands. With the financial aid of neighbours, the group acquired a measuring device to see what was going on, for although "I cannot smell it, I cannot see it, I do want to know it" (Interview S1) (see picture 3.10 \& 3.11 in chapter 3). They first experimented with measuring electromagnetic fields in their homes, but the men soon shifted their attention to the flat complexes on the other side of the city that had several GSM and UMTS antennas on the roof. Their presence in the flat complexes elicited coffee table stories by tenants about headaches and other health complaints, inspiring the men to tackle the issue "in a - between quotation marks - scientific way" (Interview S1). The ensuing campaign, in which StS surveyed tenants' grievances, conducted questionnaires and recorded radiation, yielded an interesting result:

\footnotetext{
${ }^{1}$ In scientific terms, 'radiation' is a correct word. But because it has a strong connotation with radiation from ionising radiation (X-rays), which is a potent carcinogen, professionals and experts prefer to use 'electromagnetic fields'. Concerned citizens however mostly use 'radiation', as in this case.

${ }^{2}$ I refer to interviews by abbreviating the location of the case study (S for Spijkenisse, M for Maastricht, $N$ for Nieuwkoop, MA for Maarkedal, D for Drongen and E for Euverem), followed by a number indicating the anonymised interviewee. For a discussion of my methods, see later in this chapter. For a list of interviews, see Appendix 2. I have translated all of the quotes from Dutch to English.
} 
[o]n the side [of the flat] where the antennas were located - where we could also measure it - a higher percentage of tenants had all sorts of weird [health] complaints. On the other side where we had hardly measured any radiation, we also did not receive many complaints back (...) We did it in a very simple but objective way. We simply categorised everything from the front and the back of the flat and now looking at these striking differences. I mean, you can't make this up! (Interview S1).

Compelled by the complaints and public pressure, the city council promised to look into the tenants' health complaints, employing a research institute to check their evidence and instructing the Gemeentelijke Geneeskundige Dienst (GGD, Community Health Services) to examine the health complaints. The research institute's report of the measurements in different parts of town concluded that the electromagnetic fields should be considered safe, because they did not exceed the exposure limits proposed by the International Commission on Non-lonizing Radiation Protection (ICNIRP) and endorsed by the Dutch government. Based on this report, the GGD advised that siting of base stations was safe in view of health effects.

Sts objected to these conclusions and questioned the safety margins of the exposure limits. The standards, referred to by the GGD, were based only on the thermal effects of EMF, they claimed, while the group had since connected with scientists claiming that RF EMF at exposure levels below the standards could also lead to DNA damage and cancer. But despite StS's objections, neither the group nor the city council had any legal means with which the mast siting could be prevented. The group continued their battle against the expansion of a mobile phone network by giving presentations in other municipalities confronted with base station siting. They also became a contact point for people claiming to suffer from electrohypersensitivity (EHS), a constellation of complaints ranging from headaches, rashes, dizziness to insomnia attributed to exposure to RF EMF (see de Graaff and Bröer, 2012 for a discussion of EHS as a new health risk). One of the members of StS ultimately set up an international NGO called the International EMF Alliance with which he continues to draw attention to the issue of health risks from RF EMF.

\section{Setting the scene}

This account of three Martians turned out to be a tale of three citizens ${ }^{3}$ trying to prevent the siting of a base station for a wireless telephone network in their neighbour-

\footnotetext{
${ }^{3}$ Throughout this thesis I use the term 'citizen' to refer to individuals and communities who have an interest or stake in the topic of wireless communication technology. I do not define 'citizen' in a narrow, legal way, i.e. as people that are eligible to vote. Neither do I talk about 'lay people' because I do not want to emphasise a distinction in their knowledge and experiences compared to experts dealing with EMF; nor do I use the concept of 'activist' since this has a negative connotation and does not cover the broad range of citizens that engage with the siting of base stations.
} 
hood. This thesis investigates more of these stories with the aim of understanding the societal dynamics of wireless communication siting controversies. 'Siting controversies' are cases where citizens respond to the local siting of a technological infrastructure, ranging from disposal, storage and production facilities to critical components, such as base stations. The search for such geographical sites often leads to opposition from the local community - often described by implementers, policymakers, public press and academics as Not In My Backyard (NIMBY) behaviour. The NIMBY concept is also an appealing and popular way to explain opposition to mast siting given the immense popularity, ubiquity and continuing development of mobile telephony. If people have a positive attitude towards the technology itself, the argument goes, then mast siting controversies arise because of citizens' selfish reasons such as landscape pollution or devaluation of property prices or because of irrational fears about negative health effects. Remarks about citizens' seemingly incongruent behaviour - engaging around a mast siting whilst also using wireless communication technology - came up regularly in my research.

In one of the cases of mast siting controversies I investigated, one engaged citizen told me during an interview that he had installed GSM-microcells in his office (which was next to his house) to enable better mobile communication for his ICT business (Interview D1). He needed it because his employees each had a mobile phone in the office to contact clients and because, apparently, the mobile phone reception was bad in the area. Yet, this citizen did not want a mast in his neighbourhood even though it would solve the connection problems for his business. Whenever I presented this story to an academic audience, they reacted with disbelief and laughter at the presumably inconsistent behaviour of this engaged citizen. Municipal officials (ambtenaren), aldermen for spatial planning (wethouders (NL) or schepenen (B) voor ruimtelijke ordening), mayors, mobile phone operators and other government officials also shared their surprise at engaged citizens' behaviour:

[o]f course, everybody wants to make calls, which then is also weird. We don't want that mast, but we want the convenience of the mast. Just like a community centre, important to have, but nobody wants it next door (Headmaster of primary school, Interview N5).

[w] think the cited arguments [of citizens] are insufficiently relevant. Nowadays, everybody uses a mobile phone, but nobody wants a pylon in his or her surroundings (The mayor of Maarkedal in Lauwerier, 2009).

[i]t remains exceptional that citizens who complain [about base stations] hardly consider the pros and cons. Participating in traffic is much more (demonstrable) risky than the radiation of GSM/UMTS. That we had similar radiation for years from television antennas, few know. Citizens do not seem to accept the consequences of their own behaviour (e.g.: no more mobile phone calls, then we don't 
need masts), but like to point at someone else (Municipal official Zutphen, personal communication, July 30, 2012).

Throughout my research, it became a recurring finding that engaged citizens were not anti-technology or anti-GSM, -UMTS or -Wi-Fi. In most cases, they surrounded themselves with the latest wireless technologies. Citizens were very aware of this paradox themselves - "we also know that everybody has a mobile phone" (Interview MA1) and wanted to assure me that they were not against progress. The engaged citizen who installed the GSM-microcells argued that society should think about technological innovation, and about its possible side effects, in order to adjust and evaluate. He believed this viewpoint represented "more than radical rejection" (Interview D1). An engaged citizen in Nieuwkoop said, "I am in favour of innovation and progress, I have a wireless network at home, I use my iPhone a lot and even have a wireless printer" (Interview N3). In Maastricht, the same reasoning was used: "[t]he population thinks that a mast for mobile connection is necessary, definitely in this digital era. This should however not lead to rejection of our objections and alternatives" (M1, 2011, notice of objection). Nevertheless, those actors in favour of mast siting used the popularity and even necessity of wireless communication technology as an argument for the NIMBY-character of mast siting controversies.

I argue that NIMBY is not the right conceptual tool to understand mast siting controversies. The NIMBY-perspective takes for granted a dichotomy between an assumed general good (in this case: the siting of mobile phone masts) and a biased self-interest of local citizens. Academics have increasingly called for a move beyond NIMBY to more critical interpretations that better comprehend the range of motives for citizen reactions to siting (Boholm, 2004; Burningham et al., 2006; Devine-Wright, 2005, 2010; Luloff et al., 1998; Pepermans and Loots, 2011). They claim that the lack of clarity about the meaning of the concept has led to uncritical assumptions of NIMBYism, in particular about citizens and their motives to engage. From this literature, and the literature on citizen involvement in scientific practices more generally (Bröer, 2006; Hannigan, 1995; Irwin and Wynne, 1996; Irwin, 1995; Murphy, 2006; Ottinger, 2013b; Tesh, 2000), I derived four focal points that form the nexus of my investigations in this thesis.

Firstly, I focus on the role of individuals: seeing them less as irrational and emotional 'laypeople' or as selfish rational decision makers but instead as citizens embedded in diverse networks of people and forms of knowledge that have an influence on their opinion. For instance, citizens in siting controversies often engage with science, such as the members of Spijkenisse against Radiation, which leads to the contestation of scientific knowledge. Secondly, I shift my attention from the individual to collectives of individuals, as citizens often set up a neighbourhood group, such as the group in Spijkenisse. Collectives of people have their own dynamics that cannot simply be understood as the sum of individuals. The support of neighbours, for example, enables 
particular types of actions: in Spijkenisse the citizen group purchased a measuring device with financial help from the neighbours in the street. Thirdly, my focus goes beyond the locality of sitings, as local characteristics are important to understand siting controversies but do not only shape the siting dynamics. Studies have increasingly argued for the influence of institutional arrangements within particular policy domains on siting controversies, as they can for example limit the opportunities for local views to be expressed or hold misplaced assumptions of broad public support for the to-be implemented technology. The decision-making context may thus generate particular citizen responses (Bröer, 2006; Futrell, 2003; Wolsink, 2000). Fourthly, the focus on the decision-making process has also led to increasing academic interest in public participation in siting controversies. In recent years, public participation has become a popular approach - almost a panacea - for policymakers dealing with public worries about new technologies. Various academics, however, are wary of assuming that more inclusive forms of decision making will necessarily resolve siting controversies (Owens and Cowell, 2002; Petts, 2004).

In this thesis, I examine one type of siting controversy with these perspectives in mind: the siting of mobile phone masts. Through local case studies, I explore responses, engagement and situated learning of the different actors involved in siting controversies, most importantly citizens. I also take into account the regional or national level in which decisions about mast siting are entangled, in particular how the issue of mast siting controversies has been dealt with in terms of a possible negative health effect. Furthermore, I build upon the insights about public participation and deliberation by focusing on such a recent Dutch initiative in which societal actors gather to discuss the issue of mobile telephony and health, the Klankbordgroep (Sounding board) of the Kennisplatform EMV \& Gezondheid (Knowledge Platform EMF \& Health). The existing literature on mast siting controversies either is concerned with eliciting individuals' opinions about mobile telephony and mast siting or with analysing the decision-making process (see chapter 2). There is little research that does both. Yet it is important that we understand the dynamics between citizens engaging with mast siting on a local level, national decision-making processes, the role of scientific knowledge and participatory processes in order to understand why siting controversies emerged and continue to emerge, and how they develop.

I start from the recognition that siting conflicts are not technical problems with social aspects, but social problems with technical aspects. It is for this reason that I believe we must first try to understand the local dynamic in which siting takes place. This dynamic depends amongst other on the local culture, the institutional setting and societal beliefs and changes (Pepermans and Loots, 2011). Yet this thesis is not just about siting controversies pertaining to wireless communication technology or siting controversies more generally. Research on siting controversies fits into a broader academic and policy development that acknowledges the need for a different view on relationships between policymaking, science/technology and society - especially 
when it comes to emerging technologies (Blankesteijn et al., 2014b; Callon et al., 2009; Jasanoff and Wynne, 1998; Ottinger, 2013b; Stilgoe et al., 2013). As a response to these calls, governments have experimented with different ways to involve and engage publics with science and technology in the form of consultation papers, focus groups, stakeholder dialogues and citizens' juries (see e.g. Irwin and Wynne, 1996; Wilsdon and Willis, 2004). These initiatives have hardly reached the impact hoped for by governments (support for scientific or technological developments, more public interest in science and technology, etc.), but have foremost shown the limits of these approaches. As academic interest soared in these engagement exercises over the last years (also because academics have often been actively involved in setting up or analysing these initiatives), we might arguably have lost sight of other ways in which citizens spontaneously try to become involved in the agenda setting, decision making, policy forming, and/or knowledge production processes regarding science and technology (Bucchi and Neresini, 2008). There is a wealth of literature on citizen science initiatives, such as patient groups demanding influence on research priorities (Callon and Rabeharisoa, 2008; Epstein, 1996) or activist scientists helping communities living in deprived areas to challenge the neighbouring industry's scientific claims (Frickel et al., 2010; Ottinger, 2013b). Yet, siting controversies are hardly investigated from the angle of citizen engagement, and the opportunities it offers for more robust decision making.

I therefore argue that there is a fundamental need for the re-conceptualisation of citizen involvement in siting practices. If one sees citizens as 'resisting', 'protesting' or 'opposing' siting (such as in the NIMBY-terminology), mast siting controversies become a story of antagonism, of citizens being against technology and even democracy, thus making their concerns illegitimate. Yet, I claim that citizens are using their democratic rights to become engaged with decisions that affect themselves and the world they are living in. To help avoid framing citizens' behaviour in mast siting controversies a priori as caused by irrational and poor individual 'risk perceptions', I suggest using the term 'engagement' when it comes to describing the behaviour of citizens in siting controversies (also see Verhoeven, 2009). Siting controversies can then be understood as potentially productive, leading to better-informed decisions that are also more fitting. Instead of seeing siting controversies as disruptive, hostile, frustrating or challenging, we could start to see them also as a healthy sign of democracy at work (see also Wilsdon et al., 2005). ${ }^{4}$ In this way, siting controversies offer us much more than just a story of engaged citizens like the one above about Spijkenisse, but afford us a view upon the governance of innovation - without doubt a major challenge for contemporary democracies.

\footnotetext{
${ }^{4}$ This paragraph is inspired by Prof. Judith Petts' commentary as panel discussant on the symposium 'siting controversies' that Marjolein van Asselt and I organised at the Society for Risk Analysis conference in Trondheim, Norway (16-19 June 2013).
} 


\section{Case of mobile telephony}

Mobile telephony can be described as the provision of telephone and data services to phones or similar instruments that do not need wires. It is an application of wireless communication technology, together with (amongst others) Wi-Fi, radio receivers, GPS and remote controls. Wireless communication technology can transport information over a certain distance without the need of wires or cables. Base stations for mobile telephones, TV, radio, radar and satellites use electromagnetic waves, or more precisely, radiofrequency electromagnetic fields (RF EMF) (see Figure 1.1.). A base station for wireless communication technology is made up of 3 elements: an antenna (or several antennas), a supporting structure such as a mast or a building and equipment to power the base station and radio equipment (see Picture 1.2. \& 1.3.). In this thesis, I mostly deal with controversy around the siting of masts: the steel pole constructions that rise to a maximum of 40 metres and can carry several antennas from different telecom operators. I refer to base stations when talking about all constructions for wireless communication technology (masts and antennas). In the beginning of 2014 in the Netherlands, there were 29851 GSM- (Global System for Mobile Communications, 2G), UMTS- (Universal Mobile Telecommunication Systems, 3G) and LTEantennas (Long-Term Evolution, 4G) (Antenneregister, 2014). The evolution in the technology has led to increased capacity and speed. Each base station covers a certain geographical area called a cell. The magnitude of the cell varies from a few dozen meters in big cities to 35 kilometres in sparsely populated areas. More masts have to be sited in the countryside where there are obstacles between the antenna and receiver. The cell-structure requires a great number of antennas that each ensures a good connection and sufficient capacity for a particular area.

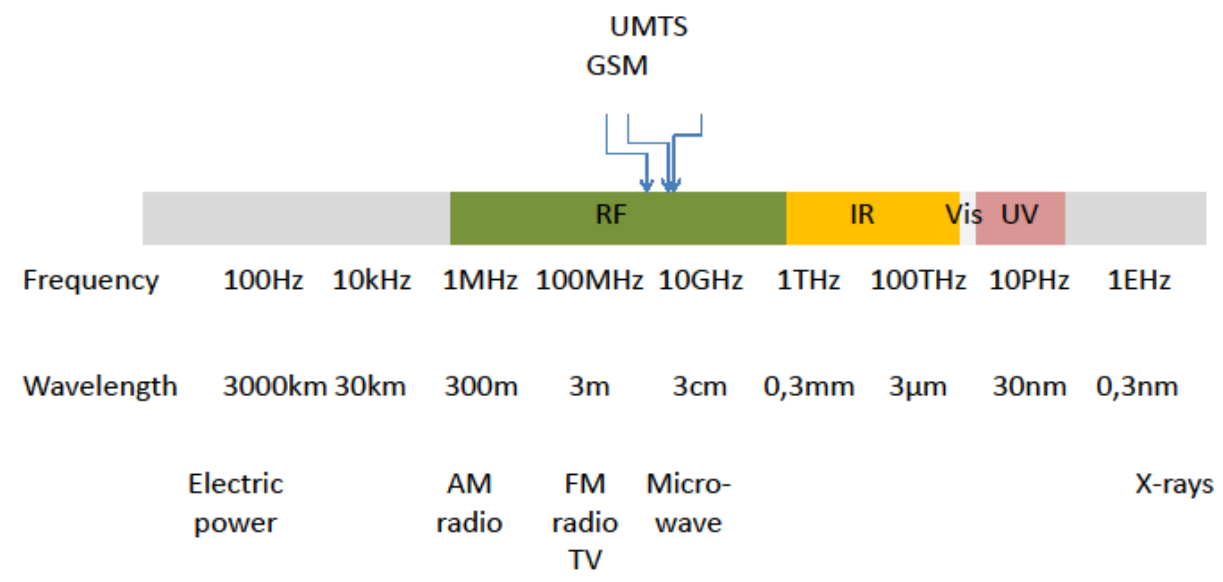

Figure 1.1. - The electromagnetic spectrum 


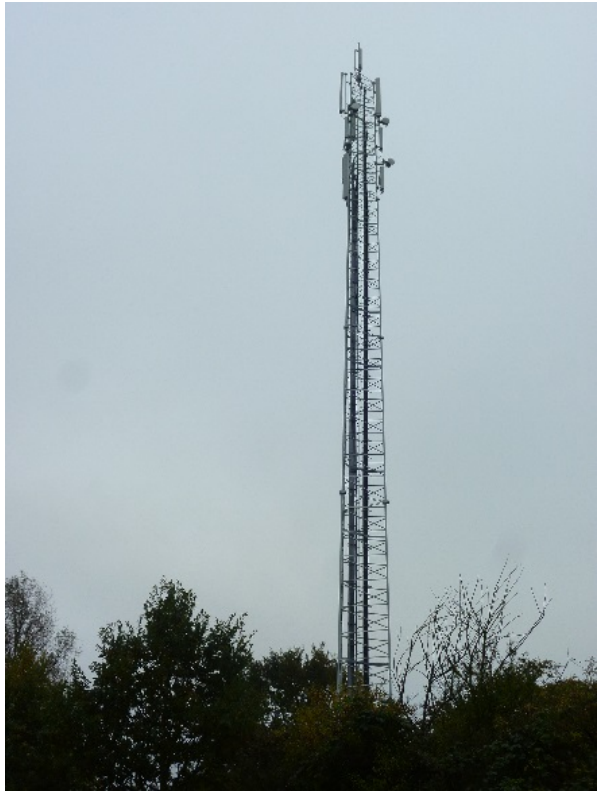

Picture 1.2. - Mast for mobile communication with several antennas in it. Photograph by author.

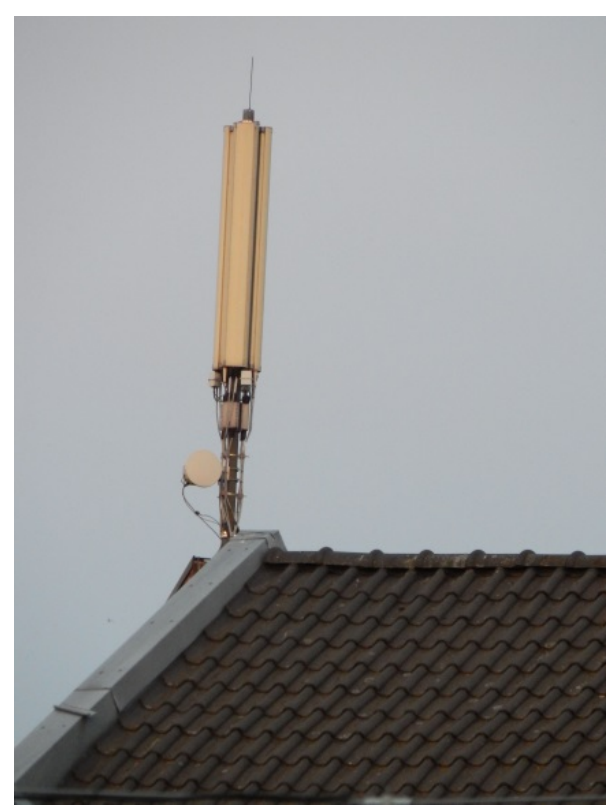

Picture 1.3. - An antenna for mobile communication on a roof. Photograph by author.

Mobile telephony has come a long way since it was heralded in the 1980s as a technology that could increase economic productivity by helping business people 'on the go' to be in constant touch with the office (Agar, 2004). It was not until the change from analogue (first generation, 1G) to digital (second generation, 2G) in the 1990s, that mobile phone use really kicked off and became affordable and available for many people. The introduction of the third generation or $3 \mathrm{G}$ transformed the mobile phone and computer industry as it enabled people to use their mobile phones as a small personal computer, the so-called smartphones and tablets. Since I started my research project, the technology has developed from the third to the fourth generation. It is very likely that by the time you read this, things will have further changed. It is astounding how swift this technology has become seamlessly integrated in our everyday lives. A life without mobile phone calls, text messaging or mobile Internet might seem quite unsettling for many of us. Even though issues of privacy, cyber-bullying and addiction received more and more attention over recent years, we as a society have not only accepted that this technology is here to stay, but we have warmly embraced it.

And yet, mobile telephony has also become a technology that triggers public reactions, especially at a local level where base stations are sited to enable the transmission and reception of mobile phone calls, messages and data. It has been on the agenda of European governments, the European Union and the World Health Organi- 
sation since the end of the 1990s. Around that time, many mobile phone operators across Europe were starting to site base stations for an increasingly popular device: the mobile phone. At the same time, citizens started to engage with the siting of these base stations. Governments and mobile phone operators started to worry as this could hamper the rollout of a mobile network - a technological innovation that was at the heart of budding ICT policies. The mast siting controversies generated strings of expert reports, policy analyses, publications and conferences, mostly focused on possible health effects from the technology. This in turn led to regulatory measures, research programmes and intensive media coverage throughout the 2000s. All these measures and actions, however, did not end the controversies around mobile telephony, but as I will argue in this thesis, reinforced it as a health issue. Within a few years, the issue of mobile telephony became firmly established as a health problem because of the dynamics between policymaking, politics, science and society.

\section{Mast siting controversies}

Mast siting controversies are instances in which citizens engage with the siting of a base station. How often do these occur? What are the reasons for this engagement? At the start of my research, I searched for an overview of cases in the Netherlands, but did not find one. As part of my research design (for a full discussion of my research design, see below.), I thus decided to map the occurrence of mast siting controversies and to investigate for each case what was the main reason for the engagement. The goal was to get an indication of the amount and diversity of mast siting controversies alongside the more in-depth analyses of several cases of mast siting controversies. We $e^{5}$ analysed half of the Dutch municipalities ( $n=211$ out of 415 ) by checking it for one or more of the following criteria: 1) the media and/or municipal officials had reported problems with siting of base stations; 2 ) there has been a judicial process about the siting; and 3) a collective of citizens rather than a single person had been actively engaged in a public discourse. The information was sought through online searches and by contacting municipal officials directly via e-mail and phone. The selection of municipalities was based on an even distribution over 12 provinces and amongst cities and countryside to account for differences in siting practices. The goal was to get an indication of the amount and diversity of mast siting controversies. The overview in Figure 1.2. shows that more than half of the researched municipalities, 129 cases out of 211, had experienced one or more mast siting controversies.

We also analysed the diversity of citizens' concerns in mast siting controversies. The analysis of mast siting controversies in the 129 Dutch municipalities indicated which concerns and arguments citizens deemed most important. Concretely this meant that we paid attention to the arguments that were mentioned most by differ-

\footnotetext{
${ }^{5}$ Elias Buchetmann assisted me with this particular research.
} 
ent sources of information such as websites or blogs from citizens involved, newspaper articles and/or municipal officials' personal communication (see Table 1.1. and Figure 1.3.). An important observation was that citizens' reactions to mast siting were generally diverse and often layered. It was hardly ever the case that citizens only mentioned one concern. In one particular case, residents handed in 20 notices of objection with several complaints stating that "the devaluation of houses, landscape pollution, health risks from radiation, other preferred locations and societal need [for mast] were contested" (Municipal official Bunnik, personal communication, June 28, 2012). Yet, figure 1.3. shows a predominance of yellow dots, which represent concerns for negative health effects from base stations. We identified 72 out of 129 cases as concerns over health effects from masts. The health concern was also often mentioned in conjunction with a concern about aesthetics, or landscape pollution, from the mast (blue, 37 cases). Other predominant reasons for siting controversies were aesthetics (9 cases, orange); democracy, i.e. citizens feel they were excluded from the decisionmaking process about the siting (4 cases, purple); devaluating of property prices (2 cases, red); technical malfunctions due to interference of radio waves (4 cases, dark green); and environmental protection (1 case, light green).

Table 1.1 - The different citizen concerns in mast siting controversies with the number of cases in which the particular concerns were expressed the most.

\begin{tabular}{llc}
\hline Concern & Explanation & $\begin{array}{c}\text { Number of } \\
\text { cases } \\
(\mathrm{n}=129)\end{array}$ \\
\hline Health & $\begin{array}{l}\text { Citizens are afraid of harmful consequences for their health caused by } \\
\text { radiation from the antenna(s) } \\
\text { In combination with aesthetics }\end{array}$ & 72 \\
& $\begin{array}{l}\text { Citizens lament being excluded from the decision-making process, they } \\
\text { feel taken by surprise and not acknowledged in their role as responsible } \\
\text { citizen }\end{array}$ & 4 \\
& $\begin{array}{l}\text { Citizens consider the base station ugly or not fitting in the environment (= } \\
\text { landscape pollution) }\end{array}$ & 9 \\
Aesthetics & $\begin{array}{l}\text { Citizens are concerned that their home will decrease in value due to the } \\
\text { close vicinity of a mast }\end{array}$ & 2 \\
$\begin{array}{l}\text { Devaluating of } \\
\text { property prices }\end{array}$ & $\begin{array}{l}\text { Citizens are concerned about technical problems of their equipment due } \\
\text { to interference of RF EMF }\end{array}$ & 4 \\
Technical & Citizens are concerned about harmful effects on flora and fauna due to \\
environmental & & 1 \\
protection & &
\end{tabular}




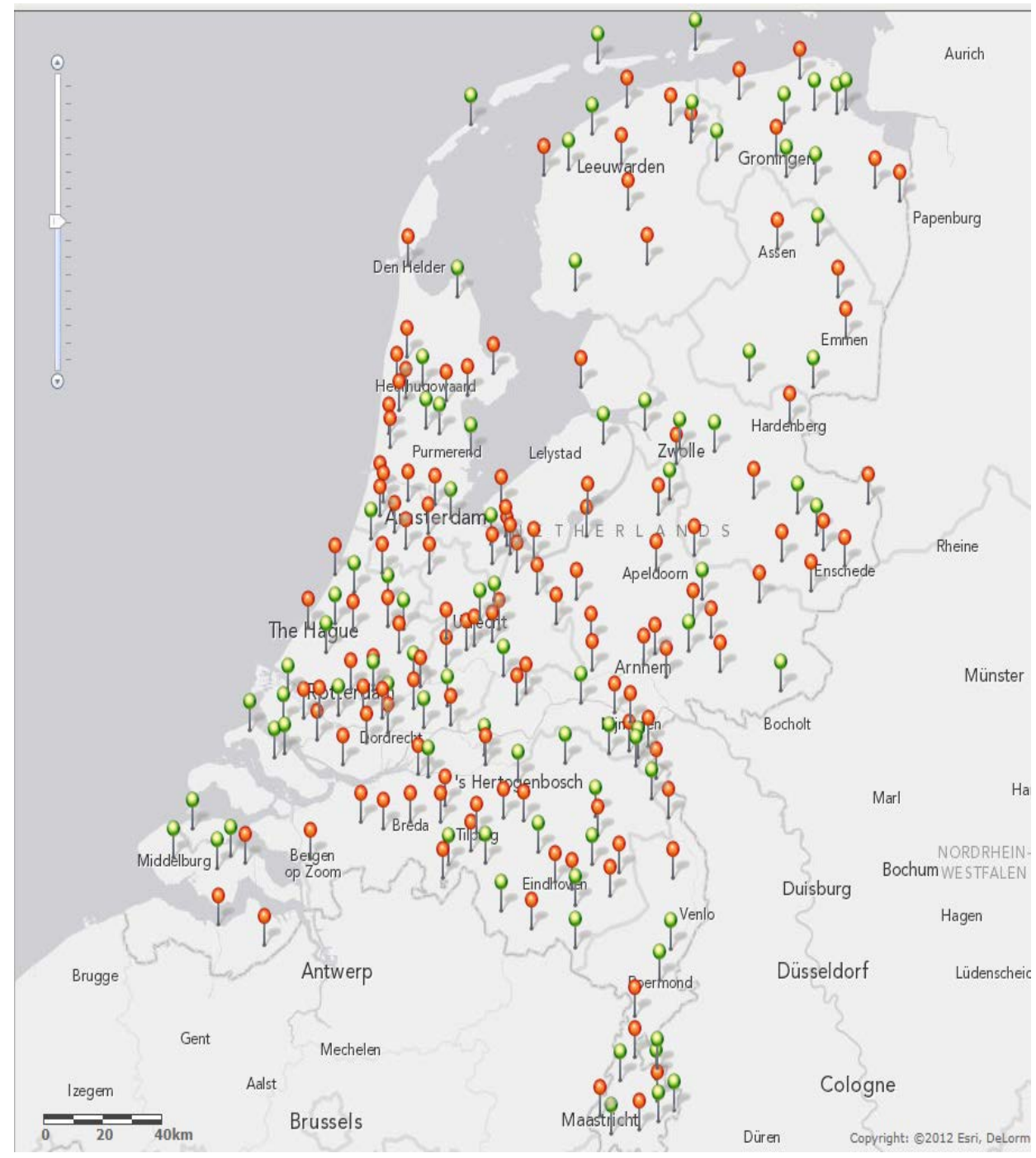

Figure 1.2. - Map of the Netherlands with an overview of 211 municipalities: 129 municipalities with siting controversies (red dots) and 82 municipalities without mast siting controversies (green dots). This map can be viewed online at http://bit.ly/KLb9lg for more detailed information (such as main reasons of concern and the year in which the controversy arose). 


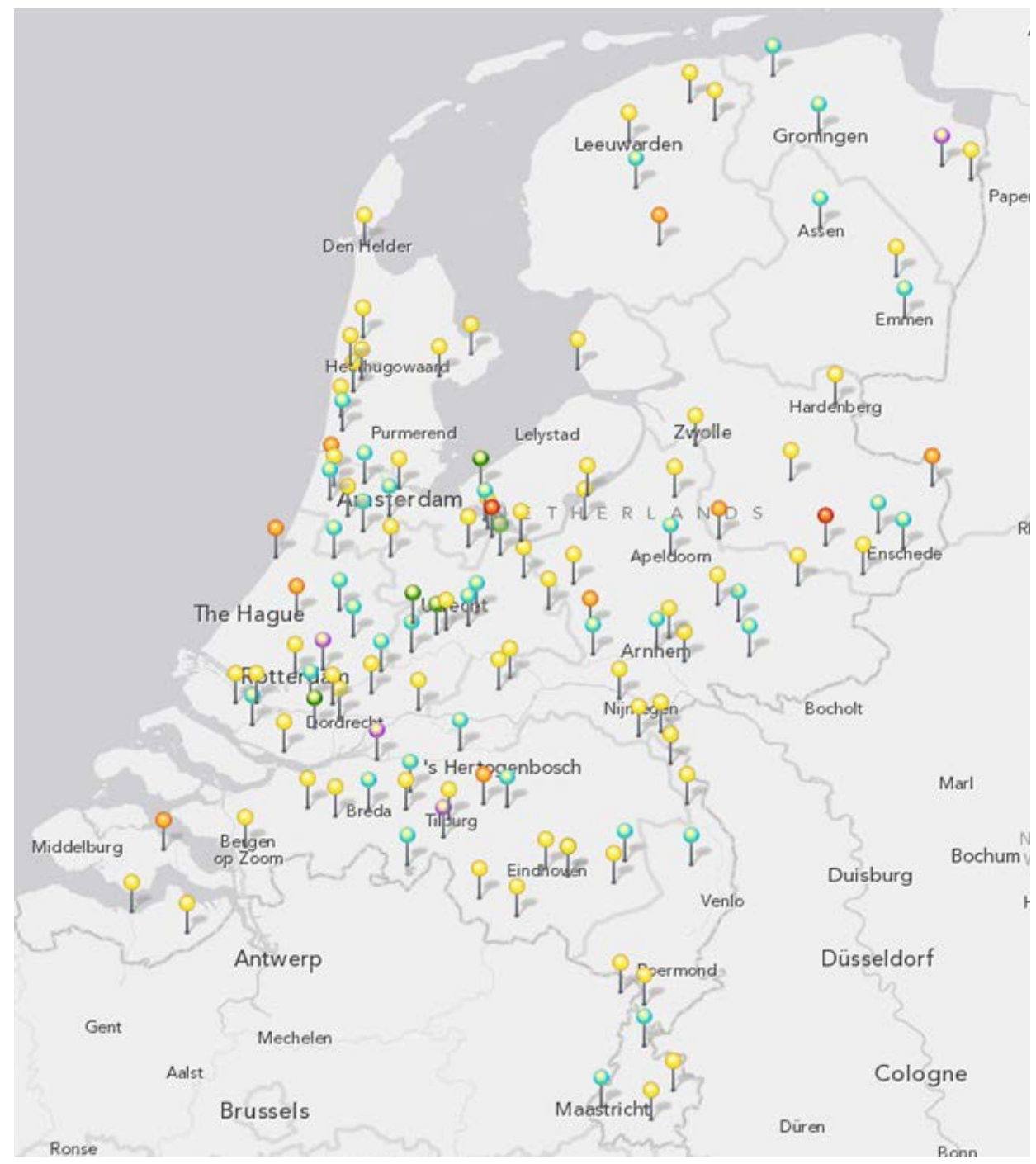

Figure 1.3. - Map of the Netherlands with an overview of municipalities with mast siting controversies. The colours represent different reasons for citizen engagement: health (yellow), democracy (purple), aesthetics (orange), devaluation of property prices (red), environmental protection (light green), technical malfunctions (dark green) and combination of arguments (blue). This map can be viewed online at http://bit.ly/1IGDHdv for more detailed information. 


\section{Engaging with risks}

Our analysis suggests that concern about health effects from base stations is the most expressed reason for citizens to become engaged with mast siting, at least in the Netherlands. Health is also the issue that municipal officials and journalists refer to most when discussing siting controversies. One municipal official, who explained the situation in his city, was surprised about the focus on health by the residents:

[o]f the known opposition against siting of masts almost $100 \%$ is attributable to perceived health aspects. We have had 1 or 2 notices of objection against the devaluation of property prices. There has hardly or never been [a notice of objection] on the basis of aesthetics or other local planning aspects. While upon those [arguments], one could be successful to ward off such facilities [masts] (Municipal official Terneuzen, personal communication, July 23, 2012).

So why is there such a dominant focus on health, even though health concerns are only one of the many issues pertaining to mast siting and more importantly, do not even seem to be a successful avenue for getting rid of the masts, according to this municipal official? Are there any known health effects?

The only established health effect is that from heating of the tissue (by a tenth part of one degree Celsius) (van Leeuwen et al., 1999). The majority view in the scientific community concerned with this issue is that there is no strong scientific evidence of any other non-thermal effects of this technology for humans (The INTERPHONE Study Group, 2010; Vecchia et al., 2009; WHO, 1993). Research into the technology can be divided into psychological (risk perception and communication), epidemiological (observe health effects in human populations), biological (human and animal experimental studies) and technical (development of measuring devices and models to understand exposure) research. A lot of the research focuses on the possibility of cancer development. Other areas of interest are physiological effects on the hormone and immune systems, neurodegenerative diseases, effects on reproduction and development (e.g. infertility), negative impacts on cognitive functions (e.g. memory and learning), and symptoms such as headaches, dizziness or fatigue (also known as nonspecific physical symptoms) (van Asselt et al., 2009). The majority of the epidemiological and biological studies have not found a correlation that can explain possible health impacts that could be attributed to RF EMF.

Informed by a review of these studies, the International Commission on NonIonizing Radiation Protection (ICNIRP) (International Commission on Non-lonising Radiation Protection, 1998) has recommended exposure limits that are based on the scientifically well-established evidence about thermal (i.e. heating) effects of EMF exposure (WHO, 1993). The issue about whether exposure below these exposure limits might still cause negative health effects is less certain and more controversial. Scientific bodies, such as the WHO, call for more research to fill the gaps in knowledge 
about the existence of possible effects below the exposure limits. There are some scientists who claim to have found effects on human health, ranging from cancer to concentration and sleeping difficulties (see e.g. Carpenter and Sage, 2007). But these latter studies are criticised for not adhering to established scientific standards of scientific research, for example, they are not according to double-blind procedures (information from the experiment is concealed from the tester, the subject or both). The positive results of these latter studies, however, get a lot of attention from those individuals and groups who (claim to) suffer from electrohypersensitivity (or EHS), a constellation of non-specific complaints that people interpret as due to an increased sensitivity they have with respect to electromagnetic fields (Baliatsas et al., 2012; Bogers et al., 2013). A biomedical explanation for EHS does not exist (at present).

Hence, according to the majority view in the scientific community, there are no clear scientific indications for negative health effects from mobile telephony. Yet, only a quick glance at the scientific literature, media reports, municipal information, citizen websites and policy papers on the topic suggests that possible health effects are, or are believed to be, at the heart of the discussions. In addition, our analysis of the mast siting controversies in the Netherlands confirms this point: even though there are many reasons for citizen engagement, in most cases (72 out of 129), concerns about health prevailed. It thus seems that most of the actors in the controversy are caught in a debate about the very existence of health effects of wireless communication technology. The key question featuring in siting controversies is 'is it safe or not?'. Policymakers have turned towards experts for information on which to base their decision making. This evidence-informed approach in policymaking is a well-rooted way of dealing with unknown technologies (Bijker et al., 2009; Hilgartner, 2000; Jasanoff, 1990; Slob and Staman, 2012; Weingart, 1999). It makes an issue - such as the siting of base stations - into a 'health risk'-issue. Once an activity is identified and accepted as a 'risk', a 'risk-based' policy approach can be applied which can be understood as "the set of standards, protocols and guidelines that define how risk objects should be assessed, evaluated, managed, communicated and monitored" (Borraz, 2011: 970). This approach requires the identification of uncertainties to turn them into 'risk-issues' that can be scrutinised by scientists, who are believed to have the authority and capacity to characterise and assess uncertainties (WRR, 2010).

In this thesis, I understand 'risk' to be a quality ascribed, through a social process, to an object (Borraz, 2008, 2011):

[r]isk is not an inherent or objective characteristic of an activity. Risk is a quality, which comes to be associated to an activity in the course of a process during which uncertainties related to the activity are converted into a risk (Borraz, 2008: 2).

I am interested in this 'conversion process' of wireless communication technology into a 'health risk'. I wonder why it is such a prevalent argument in mast siting controver- 
sies and what the effects of this framing are on the different levels of engagement and decision making. I claim that the terms 'risk', 'risk regulation' and 'risk perception' as they are conventionally used to describe the ways of dealing with or the public attitudes towards new technologies are themselves a problem. The notion of 'risk' has infiltrated our language to the extent that "risk management and risk 'talk' are all around us" (Power, 2004: 9):

[i]n recent years, 'risk' has been promoted as a universal organizing concept for improving the quality, efficiency, and rationality of governance in ways that far exceed its traditional association with the environment or health and safety (Rothstein et al., 2013: 215).

[j]ust, as a century or so ago, the idea of progress helped to name an optimistic era, so today risk, by its very pervasiveness, seems to be the defining marker of our own less sanguine historical moment (Jasanoff, 1999: 136).

In this thesis, I will examine the 'risk discourse' that has become so dominant in discussions on wireless communication technology. I am interested in whether and how different actors in the wireless communication controversy engage with this 'risk discourse'. Citizens engage with 'risks' through spontaneously becoming involved in a local mast siting decision. Their engagement around the decision to site a mast makes them familiar with the argument of health effects. Policymakers engage with 'risks' through a specific set of policy practices, i.e. by way of applying a risk-based approach that implies the need for more scientific knowledge on the issue at hand in order to make an informed policy decision. Scientists, to which both citizens and policymakers turn to, engage with 'risks' by scrutinising the technology for signs of harmfulness. In any discussion on 'risks', science thus plays a dominant role:

[t]hus the entire discussion of risk - of perception, management, and communication - is conceptually linked to the larger societal debate on the nature and role of science in our modern, industrialized civilization (Bradbury, 1989: 394).

[a]n almost diagnostic feature of risk as a topic has been the presumption that it is a fundamentally 'scientific' object (Jasanoff, 1990; Wynne, 1989), whose nature can be revealed without at the same time being 'constructed' (Felt and Wynne, 2007: 31).

I will therefore pay analytical attention to the role of scientific knowledge and uncertainties in the debates around wireless communication technology, and on the 'construction' of wireless communication technology, and the siting of base stations, as a 'risk-issue'. I will examine the pervasiveness of a 'risk discourse', in both public, politics and (social) sciences, as 'risk' seems to have become the dominant mode of explanation for the emergence of mast siting controversies and for its policy solutions. 


\section{Research questions}

My research questions thus developed out of a curiosity about the recurring observation that tensions and social dynamics that are likely to emerge in relation to new technologies are mostly understood in terms of NIMBY or 'risk'. Policymakers, scientists and the media assume that mast siting controversies arise because people do not want the infrastructure in their neighbourhood or because they are afraid of their health. It surprised me that so much social science research into this and related controversies does not question the assumption that public concerns are primarily related to health effects (see chapter 2 for a discussion of these studies). When I attended meetings about EMF at various conferences, for example, most social scientists reported the findings of their studies into the perceptions of lay people about the 'risks' of masts or mobile phones. They recommended better risk communication strategies for diminishing the concerns. I agree that it is important that authorities inform citizens properly about new technological developments and possible health risks, but I disagree with two assumptions often made by these studies: 1) that public concerns about EMF are primarily related to health concerns and 2) that the solution is to mind the gap between laypersons' and experts' views on the risks. Paradoxically, the abundance of social science research into risk perceptions of EMF, often commissioned by policymakers faced with controversy, only reinforces this view.

Instead of trying to understand why people are worried about a technology that is not considered harmful in the dominant scientific view, I would like to draw the attention to the way the issue has been dealt with by policymakers, scientists, citizens and other actors involved in siting controversies. The controversy around the 'reality' of health problems from wireless communication technology thus allows me to investigate why and how this technology has become seen as a serious 'health risk'. This question focuses on the social construction of the world through discourses and actions. Because the focus in this controversy is primarily on health, scientific knowledge about assumed health effects becomes an important resource to corroborate claims. One tactic used by the members of 'Spijkenisse against Radiation', for example, was to turn to natural scientific knowledge to find out more about an artefact - a mast for antennas - and a technology - wireless communication - they knew nothing about. It started with a simple online search on the dangers of the technology. It continued with the purchasing of a couple of measuring devices to perform their own 'research'. Eventually, they became engaged in (inter)national networks where scientists, NGOs and citizens meet to discuss health effects of this technology.

I am not concerned with judging whether a person has the 'right' knowledge about possible dangers from this technology or not, but instead I want to find out how this person deploys scientific knowledge. When I use the term 'deploy' in reference to scientific knowledge, I denote all means of acts such as mobilising, constructing, contesting or ignoring knowledge. I therefore also ask how and why different actors in the 
controversy (citizens, companies, policy bodies, scientists) deploy scientific knowledge about wireless communication technology. I answer my research questions on the basis of material gathered predominantly in the Netherlands and Flanders (Belgium).

My research questions are thus as follows:

1. How to understand the societal dynamics and mechanisms, in particular the role of scientific knowledge and uncertainties therein, that account for the emergence, sustainment and possible ending of mast siting controversies?

2. Why and how did wireless communication technology become a serious 'health risk'? Why does this 'health risk' framing dominate?

3. How do different actors in the controversy (citizens, policy bodies, scientists) use, construct, contest or ignore scientific knowledge regarding wireless communication technology?

\section{Constructing health risks}

In asking these questions about mast siting controversies - explicitly investigating the construction of the issue in terms of a 'health risk' - I ally myself with an academic community that theorises the relationships between science and society, and more specifically between society and so-called 'risk issues', from a social constructivist perspective. The idea that science is socially constructed has been the baseline of Science and Technology Studies (STS) research since the field started to investigate the 'making of science', i.e. the nature of scientific knowledge claims, in the 1970s in laboratories, zoos, botanical gardens, and research clinics (Golinski, 2008; Hess, 1997; Pickering, 1992; Sismondo, 2012). STS scholars argued that the outcome of scientific investigations is as much determined by negotiations and social processes as by assumed objective scientific methods and theory. By taking a social constructivist perspective to investigate mast siting controversies, I do not uncritically accept or deny the existence of a health problem, but instead try to unravel the social, political, cultural and scientific processes by which wireless communication technology has become defined as an (un)acceptable 'risk' and as something that needs to be acted upon (compare Hannigan, 1995; Murphy, 2006). Yet, STS is not the only research community that is engaged in research into public and siting controversies. I thus also engage with other academic communities, most importantly social scientific risk research, social movement theory research, environmental sociology and social geography.

The literature that I build upon is concerned with finding out how we assign meaning to the world around us and how we know and interact with it. It pays attention to the construction work that is needed to give meaning to particular contemporary phenomena - whether that is global warming, gay rights, youth crime or the siting of mobile phone masts. These constructionist or constructivist ideas have a long 
history in the social sciences. In the 1970s, conventional explanations for the existence of social problems were challenged by scholars (see e.g. Spector and Kitsuse, 1987) who viewed social problems not as static conditions, but as sequences of events, a process of claims making, which was believed to be more important than the task of assessing the validity of the claims themselves (Hannigan, 1995). These scholars thus focused on the 'meaning work' (Benford \& Snow, 2000, p. 613) or 'framing' (Benford and Snow, 2000; Goffman, 1974) of particular issues by individuals, groups of people such as citizens, policymakers or scientists or whole cultures or societies. This type of work has been very influential in social movement theory in which theories of framing are used to emphasise how mobilisation takes shape around and actively involves the construction of a 'problem'. Social movement scholars are interested in the ways in which activists use or even manipulate cultural frames in order to mobilise people (Tesh, 2000). Social movement literature, as well as environmental sociology, are mostly concerned with emphasising meaning and democratic processes, mostly focusing on the U.S., often taking the side of the minority groups in controversies, such as citizen groups from economically deprived areas (see e.g. Allen, 2003; Ottinger, 2013b).

Sociologists and psychologists also turned their attention to notions of 'risk' and 'danger'. They examined 'risk' as a social construct in a particular historical and cultural context. From the 1960s onwards, psychometric studies already closely examined the construction - or 'perception' in their jargon - of risk-issues by individuals. Around that time, the need to understand the public's negative reaction to emerging technologies, such as nuclear energy, increased. Psychologists accounted for these responses by looking at the complexities of the human mind. Key characteristics such as familiarity, control, catastrophic potential, equity, and level of knowledge have been proven to influence 'risk decisions' (Slovic, 2000; Slovic et al., 1982; Vlek and Stallen, 1980; see also van Asselt, 2000 for an overview of the literature). In the 1980s, anthropologist Mary Douglas and political scientist Aaron Wildavsky moved beyond the focus on the individual and her subjective estimates. They challenged the dominance of the psychometric paradigm by publishing Risk and Culture (1982) in which they introduced the 'Cultural Theory of Risk'. Cultural theorists analyse social responses to risk as being determined or constructed by cultural belief patterns that encourage individuals and social groups to adopt certain values and reject others. Cultural Theory outlines four 'ways of life' in a group/grid typology: fatalism, hierarchy, individualism and egalitarianism. The emphasis on the social construction of 'risk issues' was further explored by several risk studies scholars in their attempt to integrate the research on the public experience of 'risk' from psychology, anthropology, sociology and communication studies into an interdisciplinary framework called 'Social Amplification of Risk Framework' (SARF) (Kasperson et al., 1988; Pidgeon et al., 2003). The main thesis of SARF is that information processes, institutional structures, social behaviour and individual 
responses shape the social experience of what a 'risk' is in ways that either increase or decrease public reactions to the particular issue.

In the last decade, the concept of 'risk governance' has emerged as the critical study of complex, interacting networks in which choices and decisions are made around risks, and as a set of normative principles which can inform all relevant actors of society on how to deal responsibly with risks (International Risk Governance Council, 2005, 2007; Klinke and Renn, 2002; Stirling, 2001; van Asselt and Renn, 2011; van Asselt and Vos, 2008). Risk governance issues are related to the complexity of contemporary uncertain and/or ambiguous risks (often multi-level and multi-actor), the role(s) of science and experts in our society, and the dimensions of trust, credibility and participation (for an explanation of the genesis and analytical scope of risk governance, see Hermans et al., 2011). The notion of risk governance refers to the various ways in which many actors, individuals and institutions, public and private, deal with risk-issues. From an interdisciplinary point of view, it conceptualises policy processes as a complex web of "actors, rules, conventions, processes and mechanisms", and is concerned with "how relevant risk information is collected, analysed and communicated, and how management decisions are taken" (Renn, 2008: 9-10). Risk governance thus starts from the assumption that the possibilities of damage that society is confronted with cannot be adequately managed by existing technocratic procedures that are based on the idea that these possibilities of harm can simply be calculated.

Risk governance ideas are thus a radical shift from previous ideas on how to govern risks (see Hermans et al., 2011). Disciplines such as engineering and economics that use technical risk analyses to calculate expected benefits and monetary costs, played and still play a dominant role in the regulation of activities and substances that might pose a risk to humans and the environment. In this so-called classical or positivist risk approach, 'risk' and 'uncertainty' are believed to be predictable, even when it relates to human behaviour; and the calculation 'risk = probability $\mathrm{x}$ effect' has become the golden formula. Based on this classical risk approach, science-based governing became institutionalised as a two-way process with a clear separation between science and policy: the identification and evaluation of risk (risk assessment) and taking measures to control risks that are deemed unacceptable (risk management). The U.S. National Research Council (NRC) endorsed this model in the 1980s in a report that became known as the 'Red Book' (US NRC (National Research Council), 1983) and that was adopted by many powerful policy-making institutions in Europe. Notwithstanding this official popularity, science policy analysts and STS scholars have criticised the model for years (Hilgartner, 2000; Jasanoff and Wynne, 1998; Jasanoff, 1990; Millstone et al., 2008; Pielke, 2007; Weingart, 1999). Their critique is aimed at two assumptions. Firstly, that scientific knowledge will be readily available, is reliable and will be based on a consensus amongst scientists. Secondly, that scientific risk assessments are conducted in socially, politically and ethically neutral settings. Several dec- 
ades of social science research has indicated that there is no well-defined demarcation between 'science' and 'policy' as is typically argued. An important implication of these observations is that the development of science and technology is not simply a matter for science or government. This assertion is a key idea within risk governance. It denotes a broadening of the conventional perspective on policymaking by acknowledging that the government is not the only and perhaps not even the most important party in the organisation of society. This is particularly relevant in risk-issues that are characterised by a high degree of uncertainty and/or societal anxiety. In those instances, risk governance scholars claim that other actors need to be involved in the decision-making process.

The notion of 'uncertainty' has been of particular interest for scholars contributing to the risk governance field since they claim that traditional risk assessment tools are not adequate to deal with contemporary uncertain, complex and ambiguous risks. Many have pointed out that there is no 'real' uncertainty in public controversies and that the 'problem' of uncertainty is thus not fundamentally quantitative (Klinke and Renn, 2002; van Asselt, 2000; van der Sluijs, 2012; Walker et al., 2003). More knowledge does not necessarily mean less uncertainty and vice versa. The definition of what uncertainty is, along with other issues such as what counts as scientific evidence, what methods are appropriate, or how much evidence is enough has to be negotiated, constructed, sometimes monopolised or manipulated (Campbell, 1985). Uncertainty is thus the result of negotiations about the adequacy and relevance of current knowledge.

I adopt this broader understanding of uncertainty which encompasses both its relation to knowledge and its social dimension. I follow the definition by van Asselt: uncertainty refers to a lack of knowledge and the difficulty to predict future events, outcomes and consequences (van Asselt, 2000). The 'social dimension' thus denotes situations in which individuals, groups, communities, cultures or everyone experience, construct or ignore doubt on something that matters in view of decision making and acting, which is partly or fully possible, because (scientific) knowledge is perceived or portrayed as limited (van Asselt, 2005). Uncertainty should thus be understood as that which emerges from negotiations about the adequacy and relevance of current knowledge. The issue of mast siting, which is the focus of this thesis, is characterised by uncertainty, because at least some relevant stakeholders and scientists hold the view that there exists significant uncertainty about potential adverse health effects. As mentioned earlier, I understand 'risk' in the same way, as a quality ascribed to an object or activity through a contended social process. In situations of uncertainty, decision makers can try to convert 'uncertainties' into 'risks', or in other words, resort to a risk-based approach with which to determine the acceptability of adverse outcomes. In recent years, risk governance scholars have become increasingly interested in exploring the dynamics of risk-based governance, as risk has become a key organising concept for regulation and governance (Beck, 1992; Hood et al., 2001; Jasanoff, 
1999; Power, 2004; Rothstein et al., 2006, 2013; Stirling, 1998). Researchers raise questions such as: what makes this policy instrument so popular, what are the driving forces behind it; and what are the consequences, limitations or restrictions? Framing an object or activity as a 'risk' makes it governable by putting it in the hands of experts, but it is much less clear what the regulatory and societal effects are of this framing.

I relate myself to this diverse body of research in examining mast siting controversies. In different ways, these various research communities focus on 1) citizen engagement with science and technology: how they make sense of the world and changes around them; and how they act to counter these changes. Therefore, it is both about the discourses, hence the collective framing of an issue as a problem, and about the mobilisation in terms of socio-political processes of citizen actions. The bodies of literature also pay attention to 2 ) the engagement with science: how policy makers and citizens take a recourse to scientific knowledge by way of framing certain issues as 'risks'. A third theme in the bodies of literature is 3 ) the governance practices and the interaction between policy and citizens; in particular, how policy processes may influence (ignite, constrain, reinforce, etc.) citizens' meaning work and behaviour and how citizens' framings and actions might reciprocally influence policy decisions.

\section{Structure}

In chapter 2 Exploring wireless communication technology as a risk issue, I start with a literature review of the social science research on mobile telephony. The review explores the risk framing of the technology by focusing on two issues that are the main interests of social scientists studying this controversy: 1 ) citizens' reactions to the (siting of the) technology and its presumed health effects, and 2) policy responses to these societal concerns. The review serves as a starting point for my own investigation of the topic, as it identifies those issues that are in line with my own empirical findings, and other issues that I deem worthy of further research.

Chapter 3 Citizen engagement around mast siting starts from the perspective of the citizens who become engaged in mast siting controversies. I examine how and why they get involved, how they respond to mast siting and how their engagement develops. I thus focus on the societal dynamics around the emergence, sustainment and ending of mast siting controversies. I go through different important aspects of citizen engagements: the collective character of the engagement, the contact with grassroots support teams on the Internet, the landscape of knowledges and experiences in which citizens were embedded, the uncertainty around EMF health effects, and the appeal of the health risk framing. I discuss how citizen engagement can be understood as forms of non-orchestrated forms of citizen involvement in local politics. 
The citizens' perspective in chapter 3 leads me to consider the broader political and institutional context of mast siting in chapter 4, The politics of mast siting. I pay attention to the national and international dimensions of constructing wireless communication networks from the 1990s onwards by examining the dynamics that took place between international, national and local authorities, scientists, industry, citizens and the media. I discuss the government's risk-based policy strategy in dealing with mast siting controversies and the effects of this policy on the dynamics of citizen engagement.

I continue the analysis of the risk-based policy approach to mast siting controversies in chapter 5 The role of science in the antenna policy. I discuss how science became an important resource, not only for policy makers but also for societal actors who were critical of the government's interpretation of science. Science went from judge of a policy decision to being judged itself by societal actors. This development was particularly visible in discussions in the Klankbordgroep (Sounding Board) of the Kennisplatform EMV \& Gezondheid (Knowledge Platform EMF \& Health), an initiative of participatory governance that was established in the second half of the 2000s to discuss the topic of EMF and health with diverse societal actors.

The concluding chapter recapitalises the findings of this thesis and revisits the research questions by way of two focal points: the dynamics of citizen engagement and the governance approach to citizen engagement. I also pay attention to the practical consequences of my conclusion: what lessons can we learn from this particular controversy that help to increase our understanding of how best to govern innovations.

\section{The research}

Controversies seem at first sight a thick mesh of arguments, people, places, anecdotes and objects. Ethnographical methods have helped me in understanding the language used by the actors and objects that make up this controversy. I became acquainted with several communities that were engaging with the siting of a base station and interviewed people that were involved: citizens, mayors, local politicians, aldermen (wethouders) for spatial planning, journalists, lawyers, and spokespersons from mobile phone operators. I explored the networks and networking activities that these local actors were part of, paying explicit attention to the interaction between my actors and science, which led me in turn to spend time attending and observing public meetings and conferences on EMF. This allowed me to witness the networks between citizens, government officials, scientists and industry.

I followed in the tradition of STS ethnographies that are informed by Bloor's strong program (Bloor, 1976). The principles of the strong programme are as follows: 1) impartiality, adapt a principal of impartiality with respect to 'true' and 'false' beliefs, 2) causality, explain how beliefs or knowledge claims arise, 3) symmetry, give as 
much credence to successful or true beliefs as to unsuccessful or dissident beliefs and 4) reflexivity, be mindful about applying these same principles to your own work as a researcher (Hess, 1997). Bloor's principles served as a guidance to deal with the intricacies of researching an on-going controversy. Firstly, my analysis did not depend on the accuracy of competing claims: whether wireless communication technology is a health risk or not did not have any bearing on my explanation for the dynamics of mast siting controversies. Next, I deconstructed and problematised knowledge claims of scientific institutions, government and public groups without drawing a priori boundaries about particular knowledge claims being more legitimate than others are. Throughout my research I aimed to avoid vilifying or romanticising any of the actors involved (Burningham et al., 2006). Yet, this does not mean that I do not value a higher-level asymmetry and partiality in social science research in which scientists make claims about inequality (Allen, 2003) or the lack of certain types of scientific knowledge ('undone science') (Frickel et al., 2010; see Hess, 2001).

From the moment I started my research, I was reminded that there are many diverse interests at stake in siting disputes and that actors are keen to get you on their side. In the early stages of my project I contacted some engaged citizens who were active online in organisations that proclaimed health risks from RF EMF (in chapter 3, I call these organisations 'grassroots support teams'). The replies followed quickly. The respondents did not see any merits in investigating mast siting controversies sociologically - most of them in fact reinterpreted my project as psychological risk perception research, of which they were very critical. They did not understand why I would be interested in the social dynamics of mast siting controversies. They also did not see how this could help their cause. They wanted me to know that scientific evidence was mounting about the harmfulness of wireless communication technology: "it is by no means an innocent technology and more and more people are worried about their health" (Board member Meldpunt Gezondheid en Milieu (Dutch organisation for monitoring health and environment), personal communication, 14 \& 21 August, 2009). My research was viewed with suspicion: not only was one of my supervisors linked to a scientific advisory body ${ }^{6}$ that was critical of claims that RF EMF is dangerous, my research could also be used by the government to suppress citizens' reactions. Ethnographic handbooks warn researchers about this:

[p]eople will often be concerned with what kind of person the researcher is more than with the research itself. They will try to gauge how far the ethnographer can be trusted, what he or she might be able to offer as an acquaintance or friend, and perhaps also how easily he or she could be manipulated and exploited (Atkinson \& Hammersley, 2007 (1983), p. 65)

\footnotetext{
${ }^{6}$ Prof. Wim Passchier has worked for 22 years for the Gezondheidsraad (Health Council of the Netherlands) most of the time as the deputy executive director prior to becoming my supervisor.
} 
In a few cases, potential interviewees needed the reassurance that my research was not funded by the telecom industry. Most of the time, however, interviewees were very keen to share their knowledge and experiences of mast siting with me.

\section{Case studies}

Since I was interested in the dynamics of siting controversies and how scientific knowledge played a role in there, I decided to investigate a small number of cases of mast siting controversies in-depth. Case study research is a particularly apt method when dealing with a contemporary situation over which the researcher has little or no control and is thus required to be sensitive to the context of the object that is being studied (Yin, 1994): "[a] case study is an empirical inquiry that a) investigates a contemporary phenomenon within its real-life context, especially when b) the boundaries between phenomenon and context are not clearly evident" (Yin, 1994: 18). The aim of case study research is 1 ) to generate meaningful insights into particular cases and 2) to make analytical generalisations. I chose to investigate six cases in-depth that allowed me to make analytical generalisations, instead of more cases that would in principle have allowed me to make statistically significant generalisations. However, it was impossible to investigate more in-depth cases for statistical generalisation with the resources and within the timeframe of PhD research. Thus, case studies were best suited for answering my research questions since they enabled to examine fundamental patterns and mechanisms that helped explain the rise, the endurance and the (possible) ending of mast siting controversies.

From the start of my project, I explored several candidate case studies on the basis of visibility and potential of the case. The cases of Spijkenisse and Drongen were an early choice because of the media attention they received, the scale of the controversy (as the protagonists involved were still active in proclaiming the adverse health effects of wireless communication technology), and the accessibility of the people involved (as I had met one of these protagonists at a conference). The openess in choosing cases meant that I was flexible and could adjust to opportunities along the way. When at the end of 2010 a mast siting controversy emerged in the town were I lived, Maastricht, I could start with my empirical research right away. Also, whenever the Antennebureau (Antenna Office), the official information office for public questions about antennas, organised an information session for the neighbhourhood about the siting of a mast close to Maastricht, I tried to attend.

I selected the cases on the basis of two criteria: 1) the 'health risk' framing in the course of the mast siting controversy and 2) the impact of the controversy. The first variable is related to the question whether health effects were a dominant theme during the citizen engagement, and at which moment (or the lack of that moment) 'health risks' became an important focus point of local discussions. As noted earlier, other reasons also prevail in mast siting controversies such as governance issues, local 
and environmental planning, aesthetics, or devaluation of property prices. This criterion accounts for three sorts of cases: a) cases where the base station has been framed as a possible 'health risk' from the very beginning, b) cases where it has been framed as a 'health risk' during the course of the protest and another framing dominated (first) and c) cases where base stations have not been framed as a 'health risk'. The second variable takes into account the impact of the protest actions. Impact could mean a) whether the municipality supported the local protest actions, and/or b) whether the citizen group won a case in court and/or c) whether the mast against which the protests were aimed is sited or not. One of the six cases (Euverem) had been chosen because of a lack of controversy; in fact, citizens there were quite happy to get better mobile phone connection. This case is included to serve as a counterbalance to the investigation of siting controversies because it allowed me to take notice of productive patterns or other dynamics that account for the lack of controversy.

Notwithstanding scholarly social scientific interest in mast siting controversies (see chapter 2 for a review), there turned out to be a lack of empirical studies into multiple cases of mast siting controversies. Existing research on mast siting controversies was mostly based on single case studies. Yet, it seemed to make sense to take several cases of mast siting controversies into account. Researchers from an ActorNetwork perspective emphasize the importance of place, thus the local settings of a controversy (Venturini, 2009) since they claim that the experience of 'risk' is mediated by place. The physical and socio-demographic features of location may give clues to reasons of emerging 'risk-issues'. It is thus important to study other local issues and in particular, how the 'place at risk' is governed. Also, place offers some of the resources and motives for political action:

social movements can hardly be understood when isolated from their local context: the fact that a similar activity will give rise to protest movements all across the country, or even in different countries (as is the case with mobile phone masts) should not hide the fact that each movement also finds in its specific context both resources and motives for action (Borraz, 2008: 9).

By investigating several mast siting controversies, I explored different local settings that accounted for different outcomes, and it allowed me to identify dynamics that came back in all cases, and hence seem more fundamental than primarily contextdependent. 
Table 1.2. - Case selection. For a description of each case, see appendix 1.

\begin{tabular}{|c|c|c|}
\hline $\begin{array}{l}\text { Mast siting } \\
\text { controversies }\end{array}$ & $\begin{array}{l}\text { Health risk framing } \\
\text { in time }\end{array}$ & Impact of protest \\
\hline SPIJKENISSE (NL) & $\begin{array}{l}\text { From beginning } \\
\text { Focus: health risk }\end{array}$ & $\begin{array}{l}\text { Municipality supportive of citizen } \\
\text { engagement } \\
\text { Mast was sited }\end{array}$ \\
\hline NIEUWKOOP (NL) & $\begin{array}{l}\text { From beginning } \\
\text { Focus: health risk }\end{array}$ & $\begin{array}{l}\text { Municipality unsupportive of citizen } \\
\text { engagement } \\
\text { Mast was sited }\end{array}$ \\
\hline MAASTRICHT (NL) & $\begin{array}{l}\text { During protest } \\
\text { Focus: landscape pollution }\end{array}$ & $\begin{array}{l}\text { Municipality trying to be supportive of citizen } \\
\text { engagement } \\
\text { Mast is sited }\end{array}$ \\
\hline EUVEREM (NL) & $\begin{array}{l}\text { Not at all } \\
\text { Focus: getting mobile connection } \\
\text { for residents \& tourists }\end{array}$ & -- \\
\hline DRONGEN (FL) & $\begin{array}{l}\text { During protest } \\
\text { Focus: from landscape pollution to } \\
\text { health risk }\end{array}$ & $\begin{array}{l}\text { Municipality supportive of citizen } \\
\text { engagement } \\
\text { Court decision in favour of citizens } \\
\text { Mast is not sited }\end{array}$ \\
\hline MAARKEDAL (FL) & $\begin{array}{l}\text { During protest } \\
\text { Focus: landscape pollution }\end{array}$ & $\begin{array}{l}\text { Municipality unsupportive of citizen } \\
\text { engagement } \\
\text { Court decision in favour of citizens } \\
\text { Mast is not sited }\end{array}$ \\
\hline
\end{tabular}

I also compared four cases in the Netherlands with two in Flanders, one of the three Belgian regions in the Northern part of Belgium. Since STS have shown us that "[h]uman responses to nature and technology are culturally embedded and placespecific", it made sense to investigate local mast siting controversies in two different legislative and political cultures (Jasanoff, 1999: 68). I took an exploratory comparative approach between the Netherlands and Flanders. It was thus not my intention to make a cultural comparison between the Netherlands and Flanders (as homogeneous units) but the latter mostly served as a contrast to the former in highlighting interesting aspects (compare Mesman (2002) who made such an exploratory comparison between the Netherlands and the USA concerning prenatal care). The case studies in Flanders thus served the goal of a research 'lens' on the Netherlands, in order to better examine and understand the dynamics of the Dutch controversies. Flanders adequately served this purpose because the region had many similarities that make an exploratory comparison possible, but was divergent enough to provide this contrasting lens. The similarities with the Netherlands were firstly found in the way the scientific side of wireless communication technology was managed by a scientific advisory body: the Hoge Gezondheidsraad/Conseil Supérieur de la Santé (Superior 
Health Council) in Belgium and the Gezondheidsraad (Health Council of the Netherlands) in the Netherlands (see van Dijk et al., 2011). Both councils also worked closely together as some of its members are advisors for both councils. Yet, their opinions on wireless communication technology differed: in 2009 the Hoge Gezondheidsraad recommended the application of the precautionary principle by lowering the exposure limits to $3 \mathrm{~V} / \mathrm{m}$ (at the common frequency of $900 \mathrm{Mhz}$ ) in order to protect the population (Hoge Gezondheidsraad, 2009). The Flemish government decided to take over this recommendation for places where people spent a lot of time (Vlaamse Regering, 2011, 2012). The Netherlands followed the recommendations of the International Commission on Non-Ionizing Radiation Protection (ICNIRP) (International Commission on Non-lonising Radiation Protection, 1998) as also recommended by the European Council (The Council of the European Union, 1999). Unlike the Hoge Gezondheidsraad in Belgium, its Dutch counterpart did not call for the lowering of exposure limits.

At first glance, mast siting controversies in the Netherlands and Flanders were also very similar to each other, i.e. they tended to go through different 'arenas' (compare Mourik, 2004): the setting up of a citizen group (social movement arena), the searching for political supporters in their local municipality or beyond (political arena), going to court on different levels (legal arena) and getting in touch with the media (media arena). In addition, in the Netherlands and Flanders, mast siting controversies had only a limited number of 'protagonists' or engaged citizens involved in mast siting controversies. Nevertheless, the impacts of these engagements were often considerable in terms of social and political responses. Lastly, the same arguments against mast siting circulated in the Netherlands and Flanders: devaluation of property prices, lack of citizen involvement in the decision-making process, fears for negative health effects of RF EMF and landscape pollution. In contrast with all four cases in the Netherlands, however, the Flemish citizen groups managed to win lawsuits against the siting of a base station. In the end, in both Maarkedal and Drongen, the mast was not sited. In this way, the Flemish case studies highlighted the importance of the (national or regional) rules and regulations, and the judicial system on the dynamics of mast siting controversies.

\section{Data collection and analysis}

The empirical basis of my thesis consisted of three parts: I collected data for 1 ) analysing my cases of mast siting controversies, 2) the policy process around mobile telephony and mast siting; and 3) the emergence and existence of (knowledge) networks around mobile telephony. Below, I will detail these research activities.

As a preparation for my fieldwork, I reviewed the literature on the topic of mobile telephony and risks and mast siting controversies (see chapter 2), I did desk research on the Dutch and Flemish situation of mast siting, and I conducted several exploratory 
interviews (see appendix 2). This allowed me to 'enter' the field well informed, but still with an open mind (Atkinson and Hammersley, 2007).

I selected 4 Dutch and 2 Flemish case studies (see Table 1.2.). The key research activities to investigate each case have been: desk study, analysing media archives and relevant policy and legal documents pertaining to the case and grassroots websites, interviewing engaged citizens and local actors and transcribing and coding the interviews. I interviewed 46 people, ranging from seven to eleven persons per case, except for the case without controversy (two interviews) (see list of interviewees in appendix 2). I identified interviewees via an Internet search on the particular controversy by looking for different types of sources: Internet websites and blogs of citizens, groups or organisations involved in the controversy, municipal information in local newspapers or on official websites, media accounts in local newspapers, jurisprudence on the particular case and other written sources (such as newsletters from local associations or schools). I also used the 'snowballing technique', i.e. asking interviewees for other interviewee candidates, to find more respondents. Most respondents, however, were found through desk study.

For each case, a case study protocol (Yin, 1994) was made prior to the start of data collection which consisted of a synopsis of the case on the basis of desk research (different arenas of controversy, timetable and interesting findings of desk research), data collection procedures (data sources and interviewee planning), interview protocol and case study specific questions. The case study protocol served as a research tool to guide the interviews and thus increase the consistency throughout and between the cases. Interviews were semi-structured, evolving around a set of themes and key questions but being flexible enough to follow the interviewee in his or her own conversation and thought-processes (see interview protocol in appendix 3). The interviews took place in the interviewee's own home and were audio-recorded with prior consent. Since I was interested in the way the issue of siting had been framed by different actors, I asked open-ended questions and did not elaborate on my specific research interest:

[a] truly open-ended question does not presuppose which dimension of feeling or thought will be salient for the interviewee. (...) [I]n qualitative inquiry one of the things the inquiry is trying to determine is what dimensions, themes, and images/words people use among themselves to describe their feelings, thoughts, and experiences (Patton, 2002: 362)

In my interviews, the interviewees could construct their stories in their own terms with me only interrupting to ask for clarifications where I felt it was necessary. Since I had analysed the occurrence of events for each particular controversy using a case study protocol in preparation to the interviews, the interviews were used less for analysing what interviewees said about the controversy (the interview as resource providing 'facts' about the engagement), but more for how s/he experienced the 
engagement with mast siting (the interview as topic - taking the interviewee's account as a social event in itself in order to analyse the ways the interviewee describes the experiences) (Seale, 2004). In order to increase data validity, all interviews were transcribed and, in a reiterative process, a number of categories were produced based on an initial reading of the transcripts. Each interview was then systematically coded and analysed using these categories with the qualitative data analysis and research software Atlas.ti (see the coding scheme in appendix 4).

The second part of my empirical research consisted of analysing the international, national, regional and local decision-making process around mast siting through desk research of online sources and through attending meetings organised by official bodies. I collected policy documents (Kamerstukken (documents from the House of Representatives of the Netherlands), press releases and legislation), and media accounts (mostly from newspapers). In order to acquaint myself with the current policy perspective on mast siting, I attended three information sessions for neighbourhoods in which a mast was planned to be sited, organised by the Antennebureau (see list of participant observations in appendix 2). The Antennebureau is the official Dutch information portal for questions about mobile telephony, and one of their tasks is to organise information sessions for citizens. They also offer courses for municipal officials to learn how to deal with questions from citizens that are open to the public. I attended two of them (see list of participant observations in appendix 2). I also attended one information session for provincial and municipal officials in Flanders (see list of participant observations in appendix 2).

For the third part of my empirical research, I paid attention to the emergence and existence of networks around mobile telephony: both top-down versions, initiated by governmental bodies or research institutes and bottom-up initiatives of citizens. For the latter, I searched for websites of local and national engagement with mast siting through search engines and the Internet archive, the WayBackMachine. ${ }^{7}$ I was also interested in instances where the networks mixed: where citizens, pressure groups and activists would meet with scientists, government officials and health care professionals to discuss issues of EMF and health. I attended two conferences on the health effects of RF EMF where the various networks met (see list of participant observations in appendix 2). In 2007, the Dutch government established the Kennisplatform EMV \& Gezondheid (Knowledge Platform EMF \& Health) to combine the knowledge on EMF and health that was present in different institutions, knowledge centres and universities throughout the country. The Kennisplatform also envisioned becoming a vital link between science and society on the topic of EMF and health. It provided a forum in the form of a Klankbordgroep (Sounding Board) where societal organisations were represented that deal with the issue of EMF and health: for example, the mobile te-

\footnotetext{
7 I cited and archived web documents that I used as sources in my thesis through WebCite (www.webcitation.org). After each web document, I added "archived at [website URL]" to ensure that the web document stays accessible for readers of this thesis even after the original URL is no longer working.
} 
lephony industry, the Dutch Organisation for Medical Imaging and Radiotherapy and citizen organisations and pressure groups who plead for the safe use of the technology (see chapter 5). Throughout my research, it became clear that the Kennisplatform and Klankbordgroep played an important role in (dealing with) the societal dynamics on siting controversies. I thus decided to attend 4 meetings of the Klankbordgroep (see list of participant observations in appendix 2) and to interview 11 persons who were involved in the Kennisplatform and Klankbordgroep (see appendix 2 for a list of interviewees).

Table 1.3. below summarises my research approach.

Table 1.3. - Summary of the research approach, for more details see Appendix 2.

\begin{tabular}{|c|c|c|}
\hline Local mast siting controversies & Policy & Knowledge networks \\
\hline Drongen (BE) & (Inter)national, regional and local & Kennisplatform EMF \& \\
\hline Maarkedal (BE) & regulation of EMF and health: & Gezondheid (Knowledge \\
\hline Spijkenisse (NL) & international organisations (such & Platform EMF \& Health) \\
\hline Nieuwkoop (NL) & as WHO and ICNIRP), European & Klankbordgroep (Sounding \\
\hline Maastricht (NL) & institutes, Dutch government, & Board) \\
\hline $\begin{array}{l}\text { Euverem (NL) } \\
\text { Mast siting controversies maps } \\
\text { (see Figure } 1.2 . \& 1.3 . \text { ) }\end{array}$ & $\begin{array}{l}\text { Flemish government and } \\
\text { municipalities involved in mast } \\
\text { siting controversies }\end{array}$ & Conferences on EMF \\
\hline $\begin{array}{l}46 \text { interviews with engaged citizens, } \\
\text { mayors, local politicians, aldermen } \\
\text { (wethouders) for spatial planning, } \\
\text { journalists, lawyers, and spokespersons } \\
\text { from mobile phone operators } \\
\text { Personal communication with municipal } \\
\text { officials (through telephone and e-mail) }\end{array}$ & $\begin{array}{l}4 \text { exploratory interviews, mainly } \\
\text { in Flanders, in order to identify } \\
\text { the main policy issues in relation } \\
\text { to EMF }\end{array}$ & $\begin{array}{l}11 \text { interviews with staff } \\
\text { members of the } \\
\text { Kennisplatform EMF \& } \\
\text { Health, grassroots support } \\
\text { teams, interest groups and } \\
\text { scientists }\end{array}$ \\
\hline $\begin{array}{l}\text { Document analysis of personal } \\
\text { communications with municipal officials, } \\
\text { media reports about mast siting } \\
\text { controversies, personal folders of } \\
\text { collected information on the mast siting } \\
\text { from engaged citizens (in the case of } \\
\text { Spijkenisse and Maarkedal), official } \\
\text { municipal information, and legal } \\
\text { documents from court cases. }\end{array}$ & $\begin{array}{l}\text { Document analysis of policy } \\
\text { documents (Kamerstukken (NL), } \\
\text { press releases and legislation), } \\
\text { media accounts (mostly from } \\
\text { newspapers), scientific papers, } \\
\text { conference proceedings and } \\
\text { municipal documents about mast } \\
\text { siting. }\end{array}$ & $\begin{array}{l}\text { Document analysis of the } \\
\text { reports of Klankbordgroep } \\
\text { meetings and other official } \\
\text { communication by the } \\
\text { Kennisplatform }\end{array}$ \\
\hline $\begin{array}{l}\text { Participant observation of } 3 \text { information } \\
\text { sessions for citizens about the intended } \\
\text { siting of a mast in the neighbourhood }\end{array}$ & & $\begin{array}{l}\text { Participant observation of } \\
\text { Klankbordgroep meetings, } \\
\text { conferences and closed } \\
\text { meetings between } \\
\text { grassroots support teams, } \\
\text { scientists and staff members } \\
\text { of the Kennisplatform }\end{array}$ \\
\hline
\end{tabular}


CHAPTER 2

Exploring wireless communication technology as a risk issue 


\section{Introduction}

Scholarly interest in the health effects of wireless communication technology increased from the end of the 1990s onwards. But it was not just physicists, epidemiologists, biologists and technical scientists that took the presumed health effects of RF EMF as a starting point for their investigations. Social scientists also found the technology an interesting case to test their theories about risk perception and communication, social movement theory or public understanding of science. For many, it was intriguing that even though the technology was so well accepted and embedded in social life, people seemed to worry about the associated health effects. Part of the social science research on the controversy thus endorsed or even reproduced the scientific framing of the wireless communication technology controversy as a 'health risk'. Social scientists from a wide range of perspectives turned their attention to the controversy over health risks from wireless communication technology. In reviewing the literature, I drew on sociological and psychological studies on risk, science and technology studies, studies by policy scientists and social movement theorists. I searched six databases using several key words', applied 'snowballing' and asked contacts in the field for relevant literature. I also included non-peer-reviewed articles, such as workshop proceedings and reports. This search generated around 50 papers.

In this chapter, 1) I summarise the social science state-of-the-art research on the topic of RF EMF, with the aim of 2) sharpening my own research focus by identifying which insights from the literature are in line with my own empirical findings and which ones I further want to investigate. For this reason, I also 3) discuss insights of my own empirical research when they fit with the existing literature. In other words, in those cases where my empirical findings are in line with the literature discussed, and when these findings do not add anything significant to the literature, I will discuss these insights in this chapter as part of the review. Since these empirical insights are only relevant in relation to the review, but are not of added value in answering my research questions, I do not come back to them in the empirical chapters (chapter 3, 4 and 5). In contrast, if the literature review pointed to aspects that were of interest for my research questions, but were not analysed in-depth yet, I will not discuss my own empirical findings in this chapter, but in the following empirical chapters.

The review revealed that two research questions are central in the literature: 'Why are people concerned about wireless communication technology?' and 'How have policymakers reacted to the public concerns?'. The chapter is thus divided in two parts (Citizens and EMF and Policymakers and EMF) in which I review the literature

\footnotetext{
${ }^{8}$ Databases used were ISI Web of Science, Science Direct, Sage Journals Online, SocIndex (EBSCO), Swetswise, and PubMed. Key words used were 'electromagnetic radiation', 'microwaves', 'controversy' and 'mobile phone', 'non-ionising radiation' and 'public protest', and 'electromagnetic fields' and 'public protest'. I also found literature using the 'snowball effect' and asking my contacts in the field for relevant literature. I also included non-peer-reviewed articles, such as workshop proceedings and reports for Dutch and EU projects.
} 
that poses and answers these two questions. In Citizens and EMF, I focus on scholarly insights about citizens' perspectives on mobile telephony and mast siting; research into the role of the media in the controversies around EMF; and case study research on local mast siting controversies that point to a dominant framing of the issue in terms of a health risk. In the second part, Policymakers and EMF, I review the literature on the divergence in regulatory approaches to EMF and on the emergence of new governance forms such as participatory processes. In the last section, I recapitulate the findings from the review, and discuss which aspects of the mobile telephony controversy I find lacking in in-depth empirical investigations. I conclude by briefly discussing my research approach in the light of the review.

\section{Citizens \& EMF}

\section{Citizens' concerns about EMF}

From the mid-1990s onwards, academic interests in possible risks from wireless communication technology and in how people experience these risks increased. This type of knowledge was considered critical, not only by scholars but also by policymakers and (health) research organisations that sponsored many of these research projects. The National Institute for Public Health and the Environment (Rijksinstituut voor Volksgezondheid en Milieu, RIVM) in the Netherlands, for example, performed a preliminary investigation into concerns about base stations in 2005 , on request of the Ministry of Health, Welfare and Sports of the Netherlands (Bolte et al., 2005). It concluded that:

[t]he number of people concerned about the location of base stations is not dependent on the actual distance of these stations from residences. Concern about electromagnetic fields seems to be mainly a matter of risk perception (Ibid.: 2)

The field of risk perception and communication has dominated research into people's reactions to and perspectives ${ }^{9}$ on wireless communication technology. They have tried to find out firstly, why people are concerned about the technology and secondly, how to better communicate information about the technology in order to alleviate some of this concern.

\footnotetext{
${ }^{9}$ I use the concept of 'risk perspective' instead of 'risk perception', not because I do not agree with the outcomes of risk perception research on EMF and health, but because I want to be critical about the often implicit normative assumptions present in risk perception research about concepts such as 'laypersons' and 'risk perception'. Risk perception has been criticised for implying a distinction between 'perceived' (by 'emotive and irrational' 'laypeople') and 'real' (by 'objective' scientists) risks (Marris, et al., 2001). If not made explicit, one can interpret these findings as drawing a boundary between one superior knowledge base above another inferior one. 'Risk perspective', in contrast, is less ambiguous. I use it to refer to the multiplicity of views on risk in various arenas.
} 
Well-established insights from psychological research explain that concerned citizens make subjective judgments that might be at odds with experts' judgement. At the end of the 1960s, Starr (1969) developed a quantitative method to look at how people weigh risks and benefits. He was one of the first to show that people accept activities that are voluntary (e.g. smoking) more than those that are involuntary (e.g. living next to nuclear power plant). So-called 'psychometric studies', rooted in psychology and decision theory, have since focused on the roles of affect and emotions in influencing how people make estimates of the 'riskiness' of a particular technology. In the field of risk perception research, the siting of base stations can be seen as a 'typical risk scenario':

exposure to radiation from the masts is involuntary and without a sense of personal control, the health consequences of exposure are presently unknown but questioned by some experts, [and] technical knowledge about radiation is limited among lay persons (Nielsen et al., 2010: 505).

Studies using the psychometric paradigm showed that wireless communication technology is considered a medium dreadful and little-known hazard (Siegrist et al., 2005). A study into risk ratings of mobile phones and base stations by participants of a public hearing (Hutter et al., 2004) found out that that the highest risks were attributed to asbestos exposures, smoking and living near a nuclear power plant. Only a minority of respondents rated the risks from wireless communication technology as 'high'.

Yet, survey results from the Eurobarometer in 2007 specified that $36 \%$ of the respondents thought that mobile phone masts affected their health 'to a big extent', 40\% 'to some extent' and 18\% 'not at all' (European Commission, 2007). In the Netherlands and Belgium respectively, $12 \%$ and $32 \%$ was concerned to a big extent, $39 \%$ and $43 \%$ to some extent and $41 \%$ and $23 \%$ not at all. The Eurobarometer survey also indicated that individuals were more concerned about base stations compared to mobile phones, a finding that has also been established by risk perception research (Hutter et al., 2004; Ruddat et al., 2010; Siegrist et al., 2005) and case study research on local mast siting controversies (Drake, 2006). In Drake's case study, citizens were well aware of this paradox but felt to have more control over their mobile phone compared to base stations. Voluntariness or perceived control was an important psychometric variable:

[i]t may seem that campaigning against a mobile phone mast whilst owning a mobile phone is either irrational or based purely on self-interest. [However] (...) it is neither of these. For several of those involved there was a genuine fear that mobile phone masts could exacerbate pre-existing medical conditions. The protesters concerned about health used their mobile phones in such a way as to minimize the perceived potential health risks and maximize the benefits of mobile phone ownership. They were more concerned about the masts, not because they 
thought they posed a greater risk than the phones, but because they had no control over that risk (Slovic, 1987) (Drake, 2006: 405).

Thus, risk perception studies show that, in the view of engaged citizens, masts are sited involuntary and are thus out of control for them to 'switch off', unlike their phones.

Relation with empirical findings from my case study research - My case study research of several mast siting controversies is in line with this finding. It explains why all of the citizens I met throughout my research had a mobile phone and other wireless devices such as tablets whilst at the same time engaging with the siting of a base station. Some explicitly told me that they were not 'anti-technology' (see the Introduction). Even those citizens that claimed to get ill from EMF exposure would tell me that I could contact them on their mobile phone, but that they rationalised its use - not keeping it close to the body, calling with an ear set, using it only as an emergency line and switching it off at night (Interview N1 \& D2). The mobile phone was thus perceived as more controllable than the base station. Therefore, my experiences with engaged citizens provide further evidence of Drake's and risk perception research insights that a lack of control increases negative risk perspectives.

Risk perception researchers have theorised that negative perspectives of health risk, and the emotions that are triggered by mast siting such as fear and anger, might be explained by different appraisal dimensions: not only control, but also certainty, fairness and trust. In a large-scale survey among the Dutch population, van Dongen et al. (2013) found that a lack of trust in government policy, coupled with low perceived control over EMF-sources, increased negative risk perspectives. More evidence for a lack of trust in authorities and mobile phone operators can be found in other studies. In three studies using a case study approach (Drake, 2006; Law and McNeish, 2007; Soneryd, 2007), engaged citizens often referred to previous industry cover-ups of health related issues such as smoking, BSE, asbestos and thalidomide to make their point that one cannot trust industry-funded research results. In Ruddat et al.'s (2010) focus group study, the high-concerned group (persons who expressed strong concerns about risks) viewed the mobile phone companies as untruthful and self-interested 'villains'.

Also the relationship between trust and fairness is known to be of importance for risk perspectives (see e.g. Earle and Siegrist, 2008). Dohle et al. (2012) investigated the influence of the emotions of fear and anger on risk perspectives and concluded that "control and fairness are important antecedents of fear and anger related to mobile communication. Fear is strongly determined by control, and anger is influenced by both control and fairness" (Ibid.: 442). A heightened sense of control could thus be achieved, according to the latter authors, by increasing fairness, for example by involving the public in base station siting procedures. Contrary to their hypothesis, 
"certainty was only weakly related to fear, and no relationship was found between certainty appraisal and anger" (Ibid.: 443). The authors speculated that since the technology was so new, people were perhaps more interested in possibilities of controlling exposure from the technology instead of knowing whether it in fact entailed a negative health effect or not. Overall the results show that anger is as important as fear in understanding 'risk judgments' about base stations since - in contrast to fear anger "strongly determines the acceptance of mobile phone base stations [and] has a strong impact on benefit perception" (Ibid.: 443).

Relation with empirical findings from my case study research - My case study research also revealed that lack of trust in the ability of governments (both local and national) and mobile phone operators to make adequate decisions on the siting of base stations had a bearing on the engagement. If citizens considered the competences low, they expressed low levels of trust and demanded good governance practices (see chapter 3). I also experienced a lot of anger and frustration during the conversations with citizens. The lack of information about and involvement in mast siting decisions was the main cause of these emotions. In some cases, feelings of fairness also played a role. In Drongen, for example, citizens referred to living in areas with existing elements of landscape and noise pollution (such as railroads). In Maarkedal, citizens did not find it fair that all the neighbours had to agree to living close to a mast, but only one (not respected) neighbour reaped the financial benefits because the mast was sited on his property.

Dohle et al. (2010) also looked into public preferences regarding base station siting and concluded that out of a choice of four attributes of base station siting, the location of the base station was found most important (35\%) compared to the decisionmaking process and the choice of building ( $24 \%$ and $23 \%$ respectively), whilst the appearance of the base station was of least importance (17\%). ${ }^{10}$ In addition, respondents preferred base stations to be sited outside of the village, a conclusion that confirmed an earlier study (Cousin and Siegrist, 2010). Dohle et al.'s analysis also corroborated another finding by Cousin and Siegrist (2010), i.e. people generally have little knowledge about the technical aspects of mobile communication: "[t]he results suggest that lack of knowledge and understanding, especially about the interaction patterns between cell phones and base stations, is associated with unfavourable base station siting preferences, which would cause more exposure for the phoning population" (Ibid.: 244). The authors referred here to the fact that siting base stations far away from residential areas does not lead to lesser exposure for the residents.

\footnotetext{
${ }^{10}$ However, in a study by Cousin and Siegrist (2010) in which they also asked participants to elicit base station siting preferences on a map, visibility was an important factor.
} 
More risk research studies have looked into public knowledge about wireless communication technology, as it is felt that the lack of knowledge or the prevalence of contradicting information is problematic for citizens to form a proper judgment. In a survey of the German population, Ruddat et al. (2010) reported low levels of information acquisition by a large section of respondents. Only $17 \%$ of respondents felt sufficiently informed about possible health effects of mobile telephony. However, most respondents did not actively search for more information either. Overall, it seemed that once people had made their minds up, they ignored additional information. This survey was preceded by focus group research in which participants were divided in a 'high-concerned group' (persons who expressed strong concerns about risks), 'low-concerned group' (persons who judge health effects to be rather harmless) and 'ambivalent group' (persons who had not yet formed an opinion). People from the ambivalent and low-concerned group were confident that they could rely on their own judgements about possible risks from mobile phones and base stations. They only passively acquired information mainly through the mass media. The high-concerned group on the other hand "actively search[ed] for more and more critical information about radiation risks and explore[d] multiple information sources other than the mass media" (Ibid.: 267). In addition, the high-concerned group also expressed their desire for more than information - they wanted to share their concerns more widely to authorities in a participatory process about the siting process.

Relation with empirical findings from my case study research - Some of my case study findings fit with Ruddat et al.'s research. Only one engaged citizen, who had previously experienced health problems from exposure to EMF in the workplace, was well informed about EMF and health. All the other citizens I spoke to knew little about masts and wireless communication technology before the mast siting controversy. Yet, from the moment they heard about the intended siting, they started to look for more information through several channels: local newspapers, acquaintances (neighbours, friends, family) and the Internet (see chapter 3). Most of the engaged citizens exhibited the behaviour of the 'high-concerned group' in Ruddat et al.'s research, not necessarily, because they were highly concerned about EMF and health, but because they were highly concerned that the information the government provided was not the entire story. They thus wanted to gather as much information about EMF and health, and especially critical information that did not agree with the government's perspective. This group of engaged citizens also wanted to become involved in the siting decision (see chapter 3).

Some risk studies have further explored the extent to which communication and reception of knowledge and information about RF EMF influences citizens' risk perspectives, spurred by the empirical finding that the public is "confronted with conflicting information by representatives of politics, science, industry, the media and civil socie- 
ty" (Ibid.: 262). The issue of communication became particularly poignant in the view of two Special Eurobarometer reports on EMF (European Commission, 2007, 2010) claiming to have noticed:

a link between the feeling of being satisfied with the information about the potential health risks posed by EMF and the level of concern: those who are not satisfied with the information are also significantly more concerned over the risks (56\%) than those who say they have sufficient information on this topic (37\%) (European Commission, 2007: 13).

Moreover, in 2010, "[o]nly $20 \%$ of respondents [said] that they have received information on the potential health effects of electromagnetic fields" (European Commission, 2010: 95). Thalmann and Wiedemann (2006) investigated the impact of different styles of information, e.g. one-sided vs. balanced or emotional vs. unemotional. They stressed that concerned people, i.e. those respondents that scored high on a set of statements about the alleged harmfulness of EMF, are even more concerned after being exposed to highly emotional risk information in which reference is made to 'frightening diseases'. The group of 'unconcerned' respondents on the other hand diminished its risk appraisal after reading the same information.

Scholars are particularly interested in how precautionary information about health risks of the technology might increase public concern. These studies are still in the experimental phase and are problematic to generalise (the psychological laboratory research is mostly conducted with students), but they do raise a lot of interest as governments feel the need to inform their citizens - without unduly alarming them. Several studies (Barnett et al., 2007; Burgess, 2004; Cousin et al., 2011; Wiedemann and Schütz, 2005; Wiedemann et al., 2006) showed that the knowledge of precautionary measures can augment rather than diminish concerns even though it is often seen by authorities as a way to lower heightened concerns. Moreover, Wiedemann et al. claimed that "information about the implementation of precautionary measures has no positive effect on trust in public health protection" (Wiedemann et al., 2006: 361).

Yet, other insights from the literature complicate matters. Timotijevic and Barnett (2006) painted a more complex picture in their focus group study, claiming that:

understandings of the general public [about precaution] were not primarily framed in terms of either concerns or reassurance. People made sense of precaution by drawing on a range of evidence from their understanding and experience of the costs and benefits of the technology as well as their often-sceptical understandings of the regulatory context in which MT [mobile technology] health risks are managed and communicated (Timotijevic and Barnett, 2006: 159).

These findings about the array of understandings and experiences people related to in order to form an opinion came back in another focus group study (Collins, 2010) that 
examined the responses of participants to media representations of base station controversies. Collins also referred to the complexities of people's perspectives on risk, which he called 'rationalities': "[r]espondents used a wide range of sources including personal networks of information and contextual knowledges to make sense of the potential and perceived risks of mobile phone technology" (Ibid.: 634). Participants relied on "personal experiences, social contexts and multiple information sources" such as the advice of family members and friends, past health experiences or the involvement in local protests against a mast (Ibid.: 627).

Summary - We can summarise the social scientific insights into citizens' concerns about EMF (mobile telephony or mast siting) as follows: 1) because the siting of masts is perceived as involuntary and out of citizens' control, it is more likely to contribute to negative risk perspectives on siting. In addition, 2) fairness and anger are emotions that contribute to this process. In the general population, 3) knowledge about EMF and health is limited, and, according to Ruddat et al. there is not a lot of incentive for people to start looking for information. This is however different for the groups of 'concerned people' that some researchers differentiated in their studies. Those individuals wanted information from different sources and wanted to become involved in the decision-making process about mast siting. The citizens I spoke to in my research mostly resembled these 'high-concerned groups' found in the literature, in the sense that they were highly concerned about mast siting (which is not the same as being highly concerned about EMF health risks), and wanted more information and more involvement in mast siting. Another topic that received quite some scholarly and policy interest is risk communication of health risks from mobile telephony. However, most of these studies had limited explanatory value because of their experimental setup. Even though these latter studies showed that concerns about health risks from EMF increased after being exposed to risk information about the technology, they did not make clear how this information was digested, and how people in general made sense of the technology. The few studies using focus group research showed that risk perspectives were embedded in social and personal contexts, networks and (past) collective and personal experiences.

Hence, the scientific ways in which people's perspectives on wireless communication technology are extracted range from large-scale surveys with questionnaires to focus group research with a limited number of people but more time to go deeper into their perspectives. No matter what type of research design was chosen, I claim that it always runs the risk of endorsing or even reproducing the scientific framing of the wireless communication technology controversy as a 'health risk'. If research starts from the assumption that base station siting controversies or public concerns about wireless communication technology are about 'risks', then the aim of the research is to find out why the technology is deemed to be a 'risk', how 'risky' the technology is deemed to be and what risk communication strategies can be developed to 
remedy this discrepancy. Some of the studies thus (more often implicitly than explicitly) portrayed the social dynamics around mobile telephony as a 'problem' of public misunderstanding of EMF science and suggested as solution to put more efforts into better risk communication to change these views.

\section{The role of the media in mast siting controversies}

Various scholars paid attention to the role of the media (radio, TV and newspapers) in the mobile telephony controversy. The role of the media in heightening or amplifying risk perspectives has been the focus of risk researchers for many years, in particular those interested in the social amplification of risk framework (Petts et al., 2001; Pidgeon et al., 2003). The arguments about the media and risk perspectives range from blaming the media for igniting and sustaining citizens' concerns to understanding the media as one source amongst many others from which citizens draw to make sense of risks. Also in the few studies on mobile telephony and the media, these two perspectives were found. Burgess $(2002,2010)$ claimed that "the media have been instrumental in elevating health concerns about nearby masts" since "[t]he national media's problematization of cell phones and the local media's encouragement of campaigns against all towers combined to give considerable momentum to campaigning on the tower issue" (Burgess, 2004: 82-83). Burgess (2010) stated that media in the U.K. have taken on a "risk campaigning role" (p. 62), with the BSE crisis of the 1990s as an incentive for media to attack the denial or downplaying of risks. At the same time that the lessons of BSE were being digested, speculations over possible harmful effects from wireless communication technology arose, focused on mobile phones and base stations.

Vasterman et al. (2008) reported on the media coverage of citizen engagement around the siting of UMTS masts and antennas in the Netherlands, using content analysis and interviews. They aimed to counter the criticism that the media regularly receive about how they report risk and scientific topics: critics accuse the media of being biased, exaggerating the gravity of events or polarising the debate. The authors showed that the media always operate in a social context in which several actors define the issue. They found that the sources of the media information in the UMTS-case were predominantly residents, followed by local politicians and then telecom operators/corporate business. Residents talked about risks and negative consequences and their engagement, while local politicians addressed policy issues. News media defined the issue in terms of several frames, according to the authors: a precaution frame (defines problem as a potential negative health effect that demands government action), followed by a technocratic frame (problem can only be solved by balancing the different interests involved), a scandal frame (builds on outrage of continuing exposure without proper action being taken) and a scientific frame (states that exposure within official limits is not a problem). The content analysis showed that "media 
are positive towards action groups and citizens, negative towards property owners and telecom operators, and neutral about local politicians" (Vasterman et al., 2008: 329). The local arena, in which citizens engaged around the siting of a base station, was thus the primary interest for journalists in the Netherlands interested in UMTS masts.

Two studies, each based on case study research of one local mast siting controversy (Drake, 2006; Law and McNeish, 2007), also examined the relationship between citizen groups and the media and pointed out that the media were important in many ways. Drake noted that the citizen group largely relied on news media reports to keep informed about the issue. In both cases, local media reported about the campaigns against the base station. Even though the media were sympathetic towards the citizen group, they did not simply communicate the citizen group's message in a unilateral way. In Drake's case, the citizen group was most concerned about possible health effects, but despite several interviews with key campaigners, the local press did not emphasise the health aspect but focused mainly on the planning issue. Law and McNeish (2007) also showed how campaigners advanced their case through strategic use of the media: the citizen group undertook "a concerted effort to generate public awareness of the planning and health issues by ensuring coverage of the story in local media" (Ibid.: 448). Yet, the citizen group was also critical about the newspaper coverage, and became frustrated about "the inability to get Airwave's [the citizen group] perspective properly represented in the local press" (Ibid.: 449). The three authors agreed that the media, and especially the local media, were crucial in understanding local mast siting controversies, but that in their research there was no evidence of the local media taking on a "risk campaigning role" (Burgess, 2010) to advance arguments about possible health effects from base stations.

Relation with empirical findings from my case study research - The social scientific research on the role of the media in mast siting controversies can be summarised as consisting of two viewpoints: the media (especially local newspapers) have been instrumental in amplifying citizen engagement with mast siting; and neither the media nor citizens uncritically take over or influence each other's views on mast siting. My research findings also showed that the media, and especially the local newspapers, were an important source of information for engaged citizens, and that local journalists were very interested in talking to the engaged citizens, even to the extent that they would attend their meetings. Yet, in none of my cases did the media shape the course of the engagement. Engaged citizens were mostly very aware of the potential of the media (mostly local newspapers) as an outlet for promoting their cause, and used their personal contacts with local journalists accordingly. 


\section{Citizens in mast siting controversies}

Case study research of mast siting controversies (including interviews and document analysis) by Drake (2006), Law and McNeish (2007) and Soneryd (2007) showed that citizens expressed various concerns about the mast, but that health concerns often took precedence in the end. Drake (2006) and Law and McNeish (2007) were critical of describing mast siting controversies as cases of Not In My Backyard behaviour (NIMBY) because landscape pollution and the devaluation of property prices was debated. Law and McNeish asserted that house prices were not an issue for the core set of the citizen group they investigated, but health concerns were. The focus on the public health issue cannot easily be explained by NIMBY behaviour, they claim, because it "goes beyond the narrow confines of immediate locality" (Law and McNeish, 2007: 447). Also Drake asserted that a NIMBY explanation "ignores the issue of scale" (Drake, 2006: 405). In all cases, the planning debate was not restricted to local concerns but other issues related to the necessity of $3 \mathrm{G}$ technology, the role of the operators in funding scientific studies or general concerns about the future of the environment were also voiced. As Soneryd put it:

[i]n protests against the $3 \mathrm{G}$ development and planned masts, people can be motivated by sympathy with others, concerns from themselves, or anticipation toward the capital city, the political system, or public authorities. (...) All of these concerns can be linked to societal concerns, however, as they always begin with reflections on how we want to live and the type of society we want (Soneryd, 2007: 302-303).

The 'issue of scale' was also visible in the extent to which local citizen groups forged networks that stretched beyond the local community. One of the citizen groups (Law and McNeish, 2007) did not only lobby local elected representatives but also focused their attention towards the Scottish Parliament, joining forces with other local groups to demand a moratorium on further expansion of the wireless communication network. According to Drake and Law and McNeish, NIMBY was thus not the right analytical approach to understand mast siting controversies since citizens "rationally deployed their high levels of educational, cultural and organizational resources" to voice their concerns about health, the environment and local democracy (Law and McNeish, 2007: 452). None of the citizens represented the actions of the group as "an unthinking, zero-sum rejection of technology and science" but instead were much more concerned with raising "universal questions concerning the direction of modernization, development and the power of communities to participate in shaping their environment" (Ibid.: 451).

Drake (2006) observed that over time the mast turned from a problem of 'an inappropriate development' into a health concern. The protagonists of the citizen group were medically trained and wanted reassurance that the mast did not pose a 
health threat: "[w]hile acknowledging that there was no proof that mobile phone masts caused any health problems, the lack of proof that they didn't was enough for six interviewees to damn them" (Drake, 2006: 401). This is a very strong interpretation of the precautionary approach that is also found in other mast siting controversies (Law and McNeish, 2007). Drake and Law and McNeish observed that campaigners were "often those with scientific training, giving them the confidence to question the dominant scientific paradigm" (Drake, 2006: 398). Researched citizen groups focused on the potential for long-term health effects and non-thermal effects of radiofrequency fields. Some also demanded studies with a control group that had not been into contact with RF EMF exposure for a considerable period of time (also see Asveld, 2009). The critique on current scientific study results and international guidelines concerning RF EMF also led to calls for more research - to be done independently from the mobile phone industry.

Summary - The few case studies on siting controversies show some interesting dynamics. Firstly, they highlight the importance of networks: the engagement did not remain restricted to the local area, but citizens addressed national government and organisations to find support. Secondly, also in the arguments against siting, citizens stated a wide variety of concerns, both local and more global, about the development of wireless communication technology, the importance of the countryside and the policy process of mast siting. Thirdly, even though local concerns about the mast were wide-ranging, in all three case studies, concerns about the harmful effects of the exposure from the mast were dominant in the end. Yet, none of the authors gave a clear answer as to why the health framing dominated. One possible explanation in Drake's study was the medical training, and thus interest, of some engaged citizens. All three authors did point at the consequences of such a focus on health risks: citizens became interested in the scientific details of EMF research and criticised it for not looking into long-term or non-thermal effects.

Relation with empirical findings from my case study research - In chapter 1, I showed an overview of mast siting controversies in the Netherlands, and indicated that even though arguments against siting were diverse, health concerns were a dominant theme (see Figure 1.2. and 1.3.). This 'controversies map' thus confirms the findings of the few existing case studies. The map also showed that NIMBY is not an adequate explanation for mast siting controversies, because reasons for citizen engagement with mast siting were varied, and not only related to selfish personal arguments. The importance of the review in this section, however, is the fact that it pointed to three aspects in relation to mast siting controversies: the emergence of networks, the variety of arguments against siting yet the primary focus on health risks, and the engagement with EMF science. These issues served as starting points for my own investiga- 
tions into mast siting controversies. I will discuss my empirical findings related to these issues in detail in chapter 3.

\section{Policymakers' response to EMF}

The second key question asked by social science research on wireless communication technology addressed policymakers' responses. Scholars observed that policymakers had to manage a tricky problem:

[o]n the one hand, they must adopt levels of exposure, with a strong incentive to follow the recommendations of international expert groups; on the other hand, they must answer the doubts and worries of the populations living near base stations (Salomon and Borraz, 2007: 117).

Social scientists argued that governments responded to public concerns about mast siting primarily by resorting to scientists for advice on whether or not this technology posed a health risk (de Marchi et al., 2009; Kheifets et al., 2010; Salomon and Borraz, 2007; van Asselt et al., 2009; van Dijk et al., 2011; Walls et al., 2005). Even though 'regulatory science' (Jasanoff, 1990) is a well-embedded mechanism in democratic societies, obvious problems arise when experts do not agree (Jasanoff and Wynne, 1998). Despite the fact that scientists in all countries had roughly the same scientific evidence at their disposal, the advices of experts to their respective governments differed from country to country and even within countries, contributing to divergence in regulation of RF EMF. Some policymakers also experimented with new forms of governance to facilitate a regulatory decision about RF EMF in which other stakeholders besides experts, for example, citizens or NGOs, were involved. In this section, I will not refer to my own empirical findings about the decision-making processes around EMF, because I will discuss this in-depth in chapters 4 and 5 .

\section{Regulatory divergence}

In a comparative study of the role of scientific advisory bodies, van Dijk et al. (2011) observed a strong divergence between the advices of the health councils in the Netherlands and Belgium on regulatory exposure limits, even though they had the same scientific body of studies at their disposal. The Belgian Hoge Gezondheidsraad/Conseil Supérieur de la Santé (Superior Health Council) advised its federal government ${ }^{11}$ to take a precautionary approach in setting EMF exposure limits, while its Dutch counterpart the Gezondheidsraad (Health Council of the Netherlands) deemed such precautionary measures unnecessary and supported internationally proposed (ICNIRP) exposure limits:

\footnotetext{
${ }^{11}$ The competence for setting exposure limits for the technology has changed in Belgium from federal to regional government.
} 
there is no difference in the appreciation of the scientific evidence [by both councils]. They differ, however, with respect to the interpretation of the state-of-theart in terms of action perspectives: they value the available information and the many uncertainties differently and they arrive at different recommendations (van Dijk et al., 2011: 460).

Both councils thus agreed on the facts, but disagreed on the policy implications.

A study by Schütz and Wiedemann (2005) also showed that experts disagreed on the interpretation of scientific knowledge. The authors set up an expert dialogue ${ }^{12}$ on potential negative health effects from RF EMF in order to "make transparent how the different conclusions drawn by the experts have been brought about" (Schütz and Wiedemann, 2005: 533). The experts evaluated the existing evidence in different ways: they selected relevant studies and applied scientific quality standards with the goal of establishing a scientific overall assessment. The experts disagreed on all aspects. The authors explained this discrepancy by different orientations of the experts, i.e. precautionary principle versus danger prevention orientation, which formed the basis for their evaluations and risk assessments. For instance, a crucial point in the discussions concerned the special weight of studies that pointed to negative health effects. One expert claimed that these findings, even if they were scarce, should be considered as valid as long as they were not refuted by an identical replication study. Other experts disputed this statement. It became clear that evaluating scientific studies was based on elaborate interpretations and tacit knowledge of individual experts. Schütz and Wiedemann therefore concluded that "existing pre-assumptions (and their underlying values and attitudes) which guide the evaluation of evidence seem to be as important as the evidence itself" (Ibid.: 450)

In the past years, the publication of a few research reports on wireless communication technology triggered scientific and public controversy about the results and their correct evaluation and interpretation (Böschen et al., 2010; de Marchi et al., 2009). One example is the Biolnitiative report written by the Biolnitiative Group which is a group of scientists, researchers and public health professionals that call for precautionary measures and lowering of exposure guidelines based on their review of the literature (Carpenter and Sage, 2007). The report has been attacked by some authoritative bodies as 'unscientific' (Gezondheidsraad, 2008). The Gezondheidsraad claimed that the review of scientific literature was selective and that the analysis and peerreviewed process was unbalanced. This critique resonated with an earlier debate concerning a series of epidemiological studies conducted by oncologist and epidemiologist Hardell (Hardell et al., 2006, 2007). Hardell claimed to have shown a health risk for a certain type of brain tumour from long-term use of mobile phones. Hardell's critics countered that a weak statistical correlation cannot simply be equated with a

\footnotetext{
${ }^{12}$ The experts had been selected to reflect different orientations in science.
} 
causal connection in the absence of an underlying physiological mechanism (Böschen et al., 2010).

A number of social scientists investigated these controversial research reports (Böschen et al., 2010; de Marchi et al., 2009) and pointed out that the debate might seem to be a purely scientific one, conducted by scientists and scientific advisory bodies. Yet, the authors claimed, the methodological issues under discussion, such as 'what is sufficient evidence'; 'when is action warranted; 'what action to undertake'; and 'whose opinion should count', were in fact of an ethical and social nature, and should thus be seen as inherently political. Not only scientists have a say in the debate then. Van Dijk et al. (2011) concluded their article on the differences in expert advice between the two Health Councils in the same vein: in case of substantial uncertainty, advisory bodies should not attempt to offer unequivocal advice presented as the scientifically best policy option, but should outline various possible courses of action. Also Schütz and Wiedemann (2005) proposed a structure for a dialogue on risk assessment in which it became clear:

where the experts agree, where they disagree and what the reason[s], therefore, are (...) In this risk evaluation, which is no longer a task of science alone because political valuations are incorporated here, are decisions on the guiding principles of evaluation - for instance, on the application of the precautionary principle - to be made" (Schütz and Wiedemann, 2005: 543-544).

All authors thus agreed that divergence between experts and scientific advisory bodies about the outcome and policy implications of EMF science was the result of differences in opinions that led to different political interpretations of these results, as some countries took precautionary measures based on roughly the same scientific evidence. Many authors therefore argued that scientists alone should not discuss the issue, but that it needs a broader social debate.

The different policy choices also led to different levels of controversy. Several scholars (Bröer et al., 2010; Burgess, 2004; Salomon and Borraz, 2007) explained these differences by arguing that government policy played a substantial role in amplifying concerns about wireless communication technology. Burgess (2004) claimed that, in the UK, "it is the high profile given over to the issue that has itself been instrumental in fuelling concern and campaigning activity" (Burgess, 2004: 90). The attention from government institutions was embedded in a precautionary 'imperative' that lingered on after the BSE health scare. Burgess assumed that "what is a risk 'issue' is determined by the extent and character of government reaction" (Ibid.: 177). Also Salomon and Borraz (2007) concluded on the basis of a comparison between different European countries with mast siting controversies that:

the response of public authorities to these [public] oppositions amplified the dynamics of contestation: in other words, it is not so much the reactions of the local 
populations which constitute the problem, but rather their management by public authorities both at the national and local levels (Salomon and Borraz, 2007: 116).

Summary - To conclude this section, scholars interested in regulation around EMF focused on the regulatory divergences around EMF and the relation between public controversy and policy measures. A few social scientists closely examined scientists' reasoning and debates about controversial research reports. Instead of explaining this divergence as resulting from good versus bad scientific practices, the authors pointed to fundamental differences in the assessments of scientific evidence, i.e. in how to interpret and evaluate the outcomes of research or reviews, and how to act upon these findings. Some authors explained the regulatory divergence by differences in government styles: some took a more precautionary approach because of past policy experiences.

\section{New forms of governance}

In various European countries, new forms of governance surfaced in which public views were represented, alongside scientific deliberations. Social scientists analysed these initiatives, particularly in England, Sweden and France. As said, the initial reaction of most governments was to ask scientific advisory bodies for advice. Questions and concerns from journalists, politicians and the general public primarily had to be addressed by those advisory bodies, which made them an actor in the debate.

In the U.K., the National Radiological Protection Board (NRPB) was criticised for not adequately dealing with these public concerns (Stilgoe, 2005) which led to the establishment of the Independent Expert Group on Mobile Phones (IEGMP). Stilgoe $(2005,2007)$ argued that the NRPB constructed public concern as a problem outside their scope:

[q]uestions about the health effects of mobile phones, the adequacy of existing regulatory standards, or relative exposures from different handsets or masts were met with the response that the relevant technologies all complied with guidelines, which were supported by the best available scientific evidence (Stilgoe, 2007: 50).

For the NRPB, the issue at stake was 'scientific': the interaction of electromagnetic radiation with biological tissue. Citizens' concerns were tackled with a 'discourse of compliance', implying that all questions were met with the reply "that all mobile phone technology complied with (...) guideline levels, which had a well-established basis, so there was no reason to worry" (Stilgoe, 2005: 58). This discourse was essentially set as the endpoint for discussions with the public, even though the public questioned the adequacy of the guidelines and raised concerns about their experience 
with the technology, e.g. about electrohypersensitivity. In sum, the public was seen by the NRPB as "a formless mass of unfounded fears, as nothing more than the opposite of expertise" (Stilgoe, 2007: 57, emphasis in original). The experts viewed the public as "homogeneous, cognitively deficient or passive, demanding reassurance rather than engagement" (Ibid.: 56).

By 1999, the NRPB had lost all credibility in dealing with the public context of wireless communication technology. In the same year the government decided to set up a new advisory group, the Independent Expert Group on Mobile Phones (IEGMP), with two citizen members, which held public meetings and invited "a broad range of activists, scientists and other interested parties to give evidence" (Ibid.: 51). This is an example of what Walls et al. (2005) called a 'meta-governance' strategy, which is a reconciliation between two ideal types of governance: 'neo-liberal' and 'socialparticipative'. Also in Sweden, new forms of governance emerged in which citizens or non-experts were involved. The Swedish Radiation Protection Authority (SSI) initiated a Transparency Forum for Mobile Phone Communication in which some of the Swedish citizen groups that had voiced criticism on wireless communication technology participated (Soneryd, 2007). In the Swedish public forum on mobile communication, it became also evident that the issues raised by the public "tended to be translated by the authorities into "anxieties" and "fears" to be balanced against scientific evidence" (Soneryd, 2007: 297). The discussion that took place usually focused on the accuracy of facts and eventually ended in a deadlock in which every party rearticulated their polarised views.

Walls et al. (2005) concluded that even though citizens' perspectives were included in the IEGMP, participation was controlled to such an extent that these "views became framed and embedded in a largely scientific-technical discourse" (Walls et al., 2005: 654). Also in Sweden, Soneryd observed pressure to "speak in a particular fashion", which she qualified as "a dominating technical discourse rather than a focus on ethical concerns or on the driving forces of technological innovation" (Soneryd, 2007: 310). Moore and Stilgoe (2009) indicated that the so-called 'anecdotal evidence' from citizens submitted to IEGMP was used in the discussions to demarcate the boundaries of science, i.e. the anecdotes were equated with 'public concern' and sharply put against 'risks' discussed by scientific experts. The authors concluded that the 'anecdotal evidence' was held subordinate to epidemiological and other studies. Yet, the anecdotes were taken seriously "on grounds that they represent public concern, and on those grounds ought to be acknowledged" (Moore and Stilgoe, 2009: 671). Public involvement had some impact as it inspired alternative research programs.

On the basis of research on the wireless communication controversy in France, Borraz (2011) summarised these European-wide regulatory initiatives or 'pluralistic approaches' as covering three important, yet contested, dimensions: 1) the types of knowledge used, 2) the providers of knowledge and 3) the scientific and political procedures processing this knowledge. Borraz distinguished several types of knowledge: 
1) non-peer reviewed studies, 2) social and economic sciences and 3) 'anecdotal evidence' (also described as 'practical knowledge' or 'individual experiences'). The discussion of these different types of knowledges was a major challenge to expert-driven regulatory processes, according to Borraz, as it led to the questioning of the boundaries between science and non-science, and because it produced new uncertainties. For example, scientists did not consider anecdotal evidence as a legitimate type of knowledge. When the Stewart report included this knowledge, it was heavily criticised for it.

A second contented dimension Borraz distinguished was the question who can provide input in these policy processes. Usually, experts in different scientific domains dealing with EMF health risks provided input; they had the necessary credentials and knew how to behave and argue within the context of an expert body. There were, however, also other actors with different insights, values and worldviews that have been, or should have been, involved in expert deliberations, according to Borraz. Those were alternative experts (to provide non-peer reviewed studies, such as the Biolnitiative report discussed in the section above); sociologists, economists, political scientists or psychologists (they are often asked to perform risk perception studies, but rarely asked as experts in committees); and NGOs, patient organisations, or individuals (the Stewart Committee, for example, included two lay persons who had no specific knowledge on EMF).

The last dimension Borraz discussed were the scientific and political procedures needed to make the process more legitimate: he proposed to give more weight to uncertainties when analysing new technologies and to develop procedures that take into account political choices and values, and not just outcomes of scientific deliberations.

Summary - We can sum up the social scientific insights into new forms of governance as follows. All scholars identified the inclusion of different actors such as citizens without prior knowledge about EMF, NGOs or alternative scientists as a challenging exercise. Several insights attributed to this understanding: 1) it led to the demarcation between scientific and non-scientific knowledge, with the latter considered to be less legitimate; and 2) even if citizens expressed their wide-ranging concerns, the discussions nevertheless turned into a highly scientific and technical discourse, which restricted the policy outcomes of these deliberations. The social scientists analysing these processes concluded that it is not only necessary to include other types of knowledge, and thus other actors, in discussions of new technologies, but also to break open the procedures from a narrow focus on science to the incorporation of political and ethical values. 


\section{Conclusion and discussion}

In this review, I summarised the social scientific literature on the topic of RF EMF to find out which aspects of the wireless communication technology controversy have and have not been investigated. Scholars focused on two research questions: 'Why are people concerned about wireless communication technology?' and 'How have policymakers reacted to the public concerns?'.

Concerning the first question, there are a number of scientific insights that are thoroughly investigated, and that were in line with my own empirical findings. Firstly, scholars in risk perception studies have shown that the siting of masts is perceived as an involuntary act that is out of control of citizens. In risk perception research, perceived lack of control of a technology or activity is a well-known factor that can contribute to adverse responses to this technology or activity. Also in my research, citizens expressed their inability to influence the exposure coming from the mast - unlike the devices using RF EMF they used in the house - as a frustrating aspect of mast siting. Secondly, risk perception literature paid attention to the emotions that were triggered by mast siting, and identified anger and fairness as important factors in contributing to negative risk perspectives. My findings concurred with these insights. Thirdly, risk perception and focus group research differentiated between groups of citizens according to their levels of concern about health risks associated with RF EMF. Some of the mechanisms these scholars identified in the high-concerned groups fitted with the behaviour of the engaged citizens I encountered: they were highly concerned about mast siting and demanded more information and participation in the decisionmaking process.

I conclude that risk perception studies have been crucial in increasing scholarly understanding about how citizens perceive technology, but their focus on individual perspectives on risk also has its limits: 1) scholars start their investigation from the assumption that 'risk' is the main conceptual tool for understanding citizen 'resistance' against emerging technologies; 2) they extract opinions from people about masts and mobile phones, but leave out the context in which these opinions are formed; 3) scholars often give 'negative' explanations of the controversies that point to citizens' knowledge gaps or misunderstandings concerning the science behind EMF, or citizens' naïve belief in what charlatan scientists tell them. This explanation is known as 'the deficit model of public understanding of science' (Irwin and Wynne, 1996; Sturgis and Allum, 2004). Scholars have shown that this model does not do justice to the social reality of public understanding of science (see the section STS insight: the public understand science in chapter 5).

These limits of risk perception studies are addressed in scientific studies that study how citizens make sense of possible risks of wireless communication technology, and of the siting of masts. This implies looking beyond the individual and instead focusing on collectives of individuals that are to be found in mast siting controversies. 
What is missing in the literature thus far, I claim, is a focus on citizens and their collectives in the context of mast siting controversies. There were only a few studies focusing on collectives of citizens in mast siting controversies by way of a single case study (only 7). I therefore undertook a multi-case study approach, to advance systematic comparison between cases. Only some studies explicitly endorsed a comparative approach: Burgess (2002), Salomon and Borraz (2007), Borraz (2011) and van Dijk et al. (2011) compare regulations in different countries; Böschen et al. (2010), Moore and Stilgoe (2009), Walls et al. (2005) and Lezaun and Soneryd (2007) compared wireless communication technology with other technologies, for example biotechnology or GM food. However, what remains missing in the comparison between wireless communication technology cases is a focus on the societal dynamics in which citizens and their collectives participate.

\section{My research focus in the light of the review}

How do my research questions relate to the social scientific body of literature that focused mainly on citizens? I also analyse mast siting controversies from the perspective of citizens, but dive deeper into questions that were posited by scholars but not investigated in-depth. The questions I ask are: what makes citizens start to become engaged with mast siting?, what arguments do they use (also beyond possible health risks)?, and how does the health risk argument play a role? As the review has shown, technical or scientific expertise became a crucial resource in this particular siting conflict, and thus a contested issue. However, when it came to understanding citizens, most of the accounts did not problematise the role of science in the controversy. In the review, much of the social science research was about the impacts or acceptance of technologies and science, without taking a closer look at how knowledge was produced and used by citizens and other societal actors. I focus on the role of science and expertise in public arenas. There is always a question about what will count as knowledge in a given context and another about who will decide about what counts as knowledge (Cayley, 2006). I pay close attention to the process of social identity and problem construction in relation to scientific expertise around social issues that were also about risks.

In this thesis, the focus on citizens in mast siting controversies automatically leads to the consideration of the policy processes around RF EMF. A number of scholars focused on the research question 'How have policymakers reacted to the public concerns?', and concluded that policy makers asked scientific advice about the harmfulness of RF EMF from expert committees or advisory groups. The regulatory divergence, scholars explained, comes down to differences in opinion about the assessment of scientific data. A research focus that I deem worthy of further investigation is the dynamics between citizen engagement in mast siting controversies and the development of policies, including whether and how they resort to science and expertise. I 
thus analysed policy responses to this engagement and citizen responses to policy decisions.

Focusing on engaged citizens, and their responses to and participation in the governance of mast siting, allows me to both analyse local settings of mast siting controversies and the macro level settings of governance practices. 
CHAPTER 3

Citizen engagement around mast siting 
"Once upon a time....

No, not so long ago. Actually, it was only recently that Snow White and her dwarfs, who have been living on the Kafhoek for a long time, saw a very strange billboard (see Picture 3.1. \& 3.2.). With much effort and consulting thick books (Snow White and the dwarfs have no Internet) they found out what this sign meant. They learned that there is a company that wants to place a big mast, close to their home. Their home is in a lovely region where people live because the environment is still healthy and because the area is so beautiful.

What Snow White and the dwarfs considered even worse, was that in the area where they live, near to where the mast would come, a youth centre is located. Kids enjoy the centre throughout the year.

Even Grumpy, who is not so crazy about children because they make too much noise in his opinion, thought this was too much and did not understand. "If they still do not know that those mast-things and the radiation they emit are NOT dangerous, how can they then allow it? This I do not like!" he added.

The other dwarves totally agreed and wanted to organise a meeting. "Let us call the neighbours together and join forces. Together we are strong!", yelled Sleepy who had been woken up by all the noise.

And so that was done. On a beautiful day, a meeting was convened with the local residents. Some people had already expressed their willingness to gather signatures for a notice of objection. They set to work immediately and noticed that most of the neighbours were not keen on having a mobile phone mast either" (Heeel lang geleden..., 2009)

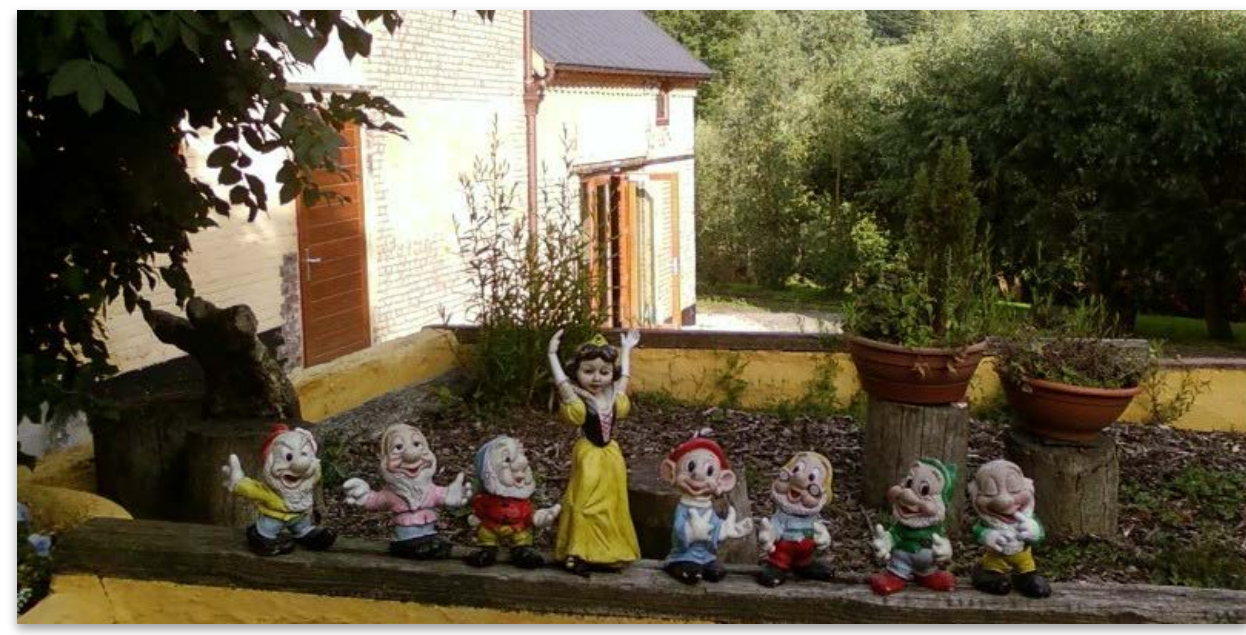

Picture 3.1. - Snow White and the Seven Dwarfs as the protagonists of a mast siting controversy in the Kafhoek, Maarkedal, Belgium. Picture taken by residents of the Kafhoek and shown on their online blog http://geensupermastopdekafhoek.blogspot.com/, entry on June 16, 2009. 


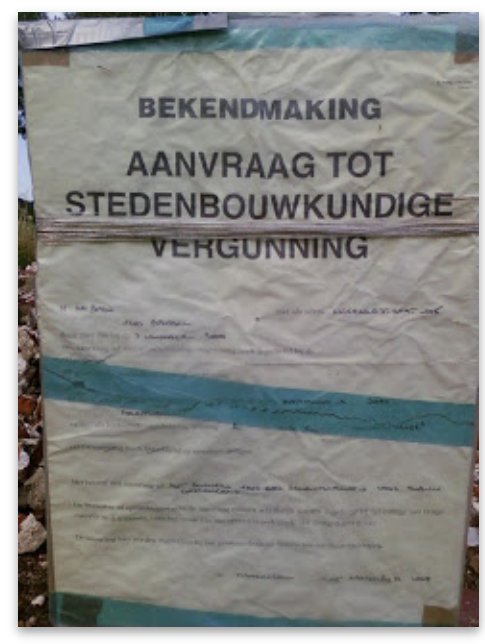

Picture 3.2. - Yellow billboard announcing the application for a planning permission to site a mast for wireless communication technology. Picture taken by residents of the Kafhoek and shown on their online blog http://geensupermastopdekafhoek.blogspot.com/, entry on June 16, 2009.

\section{Introduction}

Snow White and the seven Dwarfs feature as the main protagonists in this story of the citizens of the Kafhoek, a small rural neighbourhood of the city of Maarkedal in Flanders, who were confronted with the siting of a base station in their backyards. One of the neighbours wrote the story on a website blog called Geen Supermast in de Kafhoek (No supermast in the Kafhoek). The story illustrates why these citizens made an effort to become engaged in the decision-making process around the siting of a base station. In view of the hustle and bustle of the everyday lives we live, it can be considered striking that so many citizens spent time and effort into getting involved in mast siting controversies. It is a long, time-consuming and sometimes costly process and the outcome is very uncertain. Yet, in all of the mast siting controversies I investigated, citizens showed tremendous energy and skills in their engagement with the siting of a base station. Some members of a neighbourhood community spent several intense months, sometimes years, on planning and executing their engagement. For a few, the issue of masts and electromagnetic fields (EMF) became an integral part of their lives, a fulltime unpaid job. Why do citizens bother to get engaged? What do they think about mast siting? And how do they decide that the intended siting of a mast is something they should 'do something about' and 'make fuss about'? This chapter is based on my case study research of 6 mast siting controversies: Nieuwkoop $(\mathrm{NL})$, Spijkenisse (NL), Maastricht (NL), Euverem (NL), Drongen (FL - there were two locations of engagement, one near the station and one in the neighbourhood of Keiskant) and Maarkedal (FL). For a timeline of the engagement in each case, see appendix 1. 
In this chapter, I describe the process of citizen engagement around mast siting. The following structure (Figure 3.1.) is a schematic overview of this process.

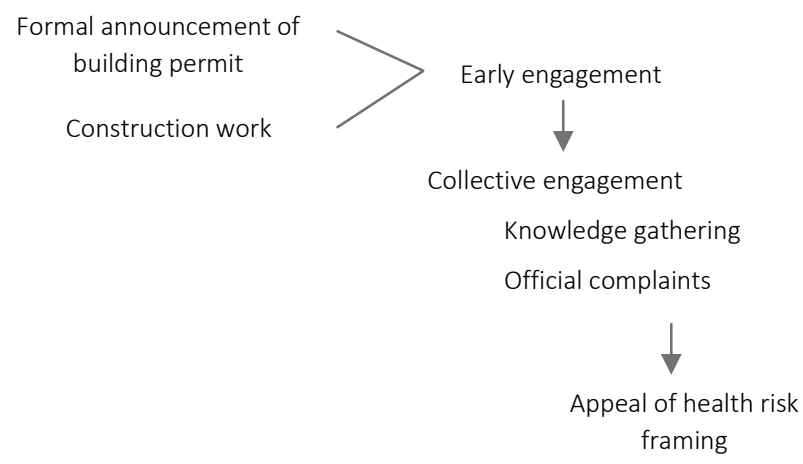

Figure 3.1. - Schematic overview of citizen engagement in mast siting

\section{Early engagement}

The moment in which early engagement became manifest was when alert citizens found out that a mast was (planned to be) sited in their direct neighbourhood. Both in Belgium and the Netherlands, the spatial planning aspect of siting masts is on par with any small project for which municipal building permission is needed (such as building a home extension or carport), so citizens needed to pay attention to actually find out that a siting was going to take place. In both countries, an exemption decision (ontheffingsbesluit) and light building permit (bouwvergunning) is needed for siting a mast, since the construction of the mast (ranging between 30 and 40 metres) is usually in conflict with the zoning plan as developed by the municipality. Municipalities in the Netherlands have to publish all requests for the mast siting in a free local paper and/or on their website. During 6 weeks, citizens have time to hand in a submission of their viewpoints (zienswijze). In Belgium, the mobile phone operator has to announce the construction on a yellow billboard that should be put on a spot where the plot of land on which the mast is to be sited intersects with a public road (see picture 3.2.). The owners of the adjacent parcels have to be notified by post. Moreover, the municipality has to publish the notification of the construction in the town hall for 30 days. During these days, anyone can appeal against the decision. In both countries, these are the normal procedures for building applications. In Flanders, the regional planning official (Gewestelijk stedenbouwkundig ambtenaar) grants or does not grant an exemption decision and building permit after receiving an advice from the municipality.

Citizens could thus be informed about the intended siting of a mast through formal, institutionalised ways of communication used by local governments and mobile 
phone operators: announcements on official billboards, in local media or through individual post. Yet, the information available through these formal channels of communication often went unnoticed. When citizens discovered the mast siting intentions, they felt caught off their guard:

[t]he municipality published [the building permit] somewhere on the back of the local newspaper. It's a good thing someone in the neighbourhood was paying attention! (Interview N3).

I also take my hat off to the correct way the municipality follows the procedure. Completely by the book. But without involving the citizens openly and honestly. The exemption decision for the mast was published in de Faam [local weekly newspaper] and made available for inspection at the town hall. That de Faam is not always and everywhere delivered in time is irrelevant. That de Faam can thus not be read by everyone: no point. And then there was an official in charge of citizen participation. Who reported soberly: look on the Internet! And what about more than half of the elderly residents who do not have a PC and let alone Internet! (Ingezonden brief, 2009).

I think there has been a lack of information to the people in this neighbourhood. The people who live directly to the mast, they had apparently been given a letter, but the radiation goes so far, has such a radius, that they should have invited the whole neighbourhood. The municipality has failed (Interview M4).

[i]t also happens during the holiday periods and then you see a little announcement somewhere in some or other local newspaper that something is going to happen and then it is assumed that people see this and react to it (Interview N1).

Citizens criticised that the announcement of the siting was inconspicuous, 'just a little note in the free newspaper', arguing that this made it hard if not impossible for most of the neighbours to actually find out about it. Or they referred to 'underhand tricks' used by the mobile phone operators: they were accused of deliberately making the announcements unremarkable or describing the site on which the mast would be sited as a 'semi-industrial zone', which did not fit the reality according to citizens as it was right next to a public sports hall (Interview D2). In Drongen, the mobile phone operator was accused of hiding the yellow billboard on which the announcement of the mast was put in the bushes: "[r]ecently we (residents of the extensive residential area) 'discovered' a very well hidden (coincidence?) yellow billboard with the announcement of a building permit of [the mobile phone operator]" (D1, 2007: 1). As a neighbour explained: "the perfidy of the company who wanted to put the mast there was so big that they almost tucked away the billboards" (Interview D1) (see Picture 3.3.). 


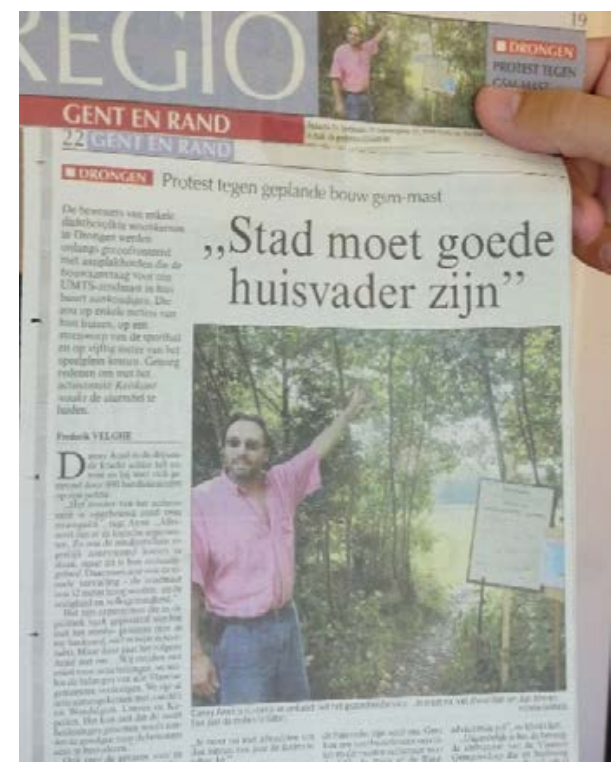

Picture 3.3. - An article about the engagement in Drongen (Keiskant) with a picture of an engaged citizen pointing to a yellow billboard that he claims was tucked away out of sight by the mobile phone operator. Photograph by author.

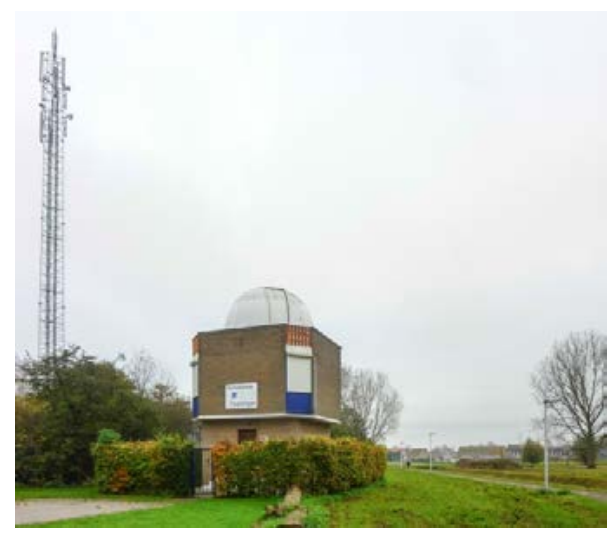

Picture 3.4. - View of the mast, observatory and Middelweg in Spijkenisse. Photograph by author.

A larger number of citizens were notified through informal networks and the local media. In all researched cases, a person acting as a mediator between the found sources of the information and citizens was necessary. In Maastricht, for example, one citizen performed this mediating role because he always paid close attention to the formal ways of municipal communication, and considered this piece of news so important that he wrote an article about it in the local newspaper, sparking citizen engagement in his neighbourhood. In Spijkenisse, the announcement of the siting of a mast on the Middelweg first went unnoticed, as nobody recognised the street name (see picture 3.4.). A journalist from the local newspaper picked up on the announcement and discovered that the Middelweg was in fact a road that crossed the middle of a park and was commonly known as the 'bus lane' in the neighbourhood. Residents became informed through his articles. A local politician explained:

[n]obody knew that this was called the Middelweg. So (...) you say 'we are going to build an antenna on the Middelweg', (...) but if there is no recognition then nobody can raise the alarm over it. Like, hey, this is close to me. So it all went well and it got approved, and when it finally was known that the Middelweg was right here, commotion broke loose (Interview S8). 
Another local politician who lived 500 metres away from the Middelweg said:

[s]o there was an announcement and probably I read it at the time, and I probably thought 'huh, the Middelweg, where is that?'. And so I didn't give it any further attention, and then say half a year later, [the siting] became an issue because obviously there had never been any objections against it. And then they talked about the bus lane all of a sudden! (Interview S7).

In the case of Spijkenisse and Drongen (station), citizens only became engaged after the municipality or local authorities had already granted the building permit for the mast and construction works had already started. In Spijkenisse, the alderman (wethouder) admitted that something had gone wrong with the communication to citizens. Because they already had granted a permit, the only option was to go to court against the mobile phone operator (Interview D6 \& S3). The municipality of Ghent (of which Drongen is a formerly independent municipality) supported the engaged citizens in their legal actions, because the regional planning official did not follow the municipality's negative advice.

Thus, early engagement started either when alert citizens picked up the news of an intended siting (Spijkenisse, Maastricht, Maarkedal and Drongen Keiskant) or when citizens were surprised by construction work (Drongen station and Spijkenisse). These alert citizens can be described as 'early engagers': they were the first individuals that noticed the (intended) siting of a base station and actively sought to become engaged in the decision-making process - a decision they believed would affect their neighbourhood. Early engagers fitted a particular profile: they were higher educated homeowners, often living in newly built or renovated houses and firmly embedded in their neighbourhoods. The fact that two of my cases, Nieuwkoop and Maastricht, were in newly built neighbourhoods is not a coincidence. Residents of new houses also use mobile phones, which may lead to a lack of capacity of the antennas in the surrounding areas. Mobile phone operators thus have to site more antennas to ensure sufficient connection. Since these new neighbourhoods are often located close to open land or countryside, high buildings for placing antennas on are scarce. Operators thus need to resort to masts for placing their antennas. Moreover, prices of the houses in these new neighbourhoods are high and people buying them are usually "young professionals with a good income. The houses, the interior decoration and the cars on the driveway tell you that", as one resident of the neighbourhood in Nieuwkoop expressed it (Interview N3). Also in Maastricht, a municipal official of the city, responsible for the antenna policy, related how the particular neighbourhood that engaged with the mast siting was a "highly educated neighbourhood where everybody protested [against the mast]. Other neighbourhoods often let themselves be walked over more easily, like 'the municipality does whatever it wants anyway'" (Interview M7).

Engaged citizens, and especially early engagers, were often active in their neighbourhood. In Maastricht and Spijkenisse, early engagers were part of the neighbour- 
hood or residents' associations (buurtplatform or bewonersvereniging) that served as intermediaries between the neighbourhood and the municipality and had the means to identify issues relevant to the neighbourhood. In the neighbourhoods without these institutionalised networks, residents shared their experiences of living in a young and vibrant area with schools, playgrounds and other amenities for children (Nieuwkoop) or living in the countryside (Maastricht). Early engagers defended their vision of their community, such as in Nieuwkoop:

[y]ou move here, knowing that your children will go to the nearby school, to sports - this is their everyday surrounding until they leave the house. That is the same for all the people [living] here. So it makes you think very differently. And those are all people who are very active in sports life, in music and theatre and that sort of thing (Interview N3).

An engaged citizen in Maarkedal explained how she had made a conscious decision to move to the countryside - showing me the view from her house of the cows in the meadow - and was thus keen on keeping the area as it was, emphasising that she did not necessarily want to sacrifice it for better mobile connection (Interview MA4). In Maastricht, one early engager conveyed why he "put forward a defence": "because it disturbs the peacefulness and quietness, there is the visual aspect in a rural area, and it is an invasion of the village character (...) All in all, it is a disturbing element" (Interview M1). Early engagers were often entrepreneurs with their own businesses in the neighbourhood. In Maarkedal, two early engagers owned a bed and breakfast in a restored historical building and an award winning youth camp respectively. As the latter said:

[w]e have renovated our [ecological] youth centre for 10 years. We received several prices for it. We have put and still put loads of energy in this project. And then they thank us with siting a giant GSM mast [next to the camp]! (Interview MA1)

In Spijkenisse, one early engager had a background in sales and marketing, which he considered very helpful in communicating his concerns about the mast to others (Interview S1). Also in Drongen, one early engager had an ICT business, situated next to his home, which had the financial benefit of being able to start a lawsuit in name of the company instead of doing it as a private person (Interview D3).

Perhaps because of the way early engagers were grounded in their neighbourhoods, many had previous experience with engaging with policy decisions. In Drongen, they had in previous years been in close contact with the municipality because of the intended construction of a highway through the neighbourhood. Back then, the community was successful in that the plans were eventually dropped. In another neighbourhood in Drongen, the Keiskant, there were two planned sitings of masts close after each other. After neighbours had been successful in stopping the 
first siting, the second one went easier because they "still had the same public support" which allowed for "the engine [to] get started more easily" (Interview D1). In Maarkedal, one of the engaged citizens had gone through a 4-year long and successful process of protesting against dumping asbestos in an abandoned sandpit in the neighbourhood. She was also a writer and knew all the local journalists. In Nieuwkoop, engaged citizens were at the time of the siting controversy also in conversation with the municipality over the safety of the roads in their newly built area. A near-accident with a little girl was the immediate incentive for a few neighbours to demand speed bumps from the municipality. But the municipality answered that the respective street did not appear on the city's list of roads with high accident incidences, causing angry frustrations from the residents (Interview N3).

Citizen engagement around the decision to site a mast could only start if alert citizens spotted the announcement of the building permit or noticed construction works of the mast. Early engagers wanted to do something against the siting, instead of "waiting at home for someone else to take care of it (...). You need to take action and not just passively watch things go by" (Interview MA4). Early engagers were active members of their neighbourhoods, with their own local businesses, functions in neighbourhood associations or as advocates of a particular lifestyle.

\section{Collective engagement}

As a next step in the engagement process, early engagers made sure that the mast siting went from being a personal issue only they were concerned about to becoming a collective problem that the whole neighbourhood - or at least a critical mass - was troubled by. Early engagers thought it was impossible to do something about the siting alone, "unless you were in politics or had lots of power" (Interview MA4). They were keen to inform their neighbours, most of whom were unaware of the intended siting: "the more people know about it, the more we were able to do something about it and to stand a chance" (Interview MA4). In Maarkedal, one of the early engagers who owned a youth centre, explained how he went to work after hearing of the intended siting:

I went to the municipality to view the building permit, to see whether it is correct. I then consulted my brother. I told him it was not good for us. Then I checked with the neighbours, what they thought (Interview MA1).

He convinced other neighbours to join. As a convinced neighbour explained: "[h]e came and warned the neighbours about what was about to happen, (...) then I said 'OK, I'm actually against it [mast] and also want to get involved with you'. That is how it started" (Interview MA4). Neighbours joined to "inform other people in the area. So everyone did particular parts of the streets. We rang the doors to inform people about what was going to happen" (Interview MA4). In Spijkenisse, three neighbours 
did the same: they decided to print some leaflets and "inform the neighbourhood" by going door to door (Interview S2). In Nieuwkoop, the main early engager had experienced health problems from exposure to a base station in his working environment. This personal experience made him quite adamant in his goal to convince his neighbours to engage with the siting of a mast, especially because it was intended to be sited in the neighbourhood of several schools. He made a 7-paged flyer to "update neighbours of the possible dangers" to their health if they would live in close vicinity to a mast. He distributed those flyers in mailboxes in his neighbourhood (Interview N1). He managed to get a few neighbours on board who became alarmed by his pamphlet, like this one:

[t]here was a small announcement in the local newspaper that they were siting a mast, a UMTS mast. At that moment I thought, OK, whatever. Then, one of the neighbours, who knew more about it, went door-to-door to distribute some information about UMTS. Then we all read it and I started to think 'oh dear, that doesn't sound very good' (Interview N2).

If a number of neighbours were willing to join the engagement against the mast, a group was established, sometimes with names like 'Spijkenisse against radiation' but more often generically called 'action group', 'working group' or 'action committee'. The groups consisted of a core of initiators - the early engagers, usually not more than 3 people - with a larger ring of supporters who were actively involved, for example, by making a website, distributing flyers, talking to press and local politicians, going door-to-door to talk to people, etc. As one core engager described it, those were "people who want[ed] to roll their sleeves up" (Interview D1). Around that set of active contributors to the collective engagement, one could draw another ring of more 'passive' citizens who also supported the engagement: those that signed petitions, read newspaper articles and blog entries, and generally listened to and sympathised with the group of engaged citizens. In Nieuwkoop, citizens collected around 200 signatures when they went round the neighbourhood, in Drongen (Keiskant) around 900. This support became also visible in other ways: one citizen leading the collective engagement in his neighbourhood told me how people approached him in the street or at a football match to ask how things were going, and to express their hope that he would make sure the mast was not sited (Interview N3).

Within this larger circle, neighbours were thus not visibly involved in the collective actions but were perceived as an important encouragement and support. If a larger number of neighbours were convinced that the siting of a mast was indeed something they should be concerned about, the group of engaged citizens was reinforced in its conviction that it was a cause worth engaging for, as expressed by this engager: 
[i]f a signature campaign at the local schools gives so much response, then you do feel that you are doing something good. And then you also know that if you then take action in a more structured way, that you will get the support. (...) You're not some loner fighting against something, but you do it for a bigger cause. And in thinking about the notice of objection, gathering these signatures, and talking to people, you realise that this is quite an important issue (Interview N3).

In all examined cases, the change of the engagement from an individual concern - "a loner fighting" - to a collective one - "a bigger cause" - was crucial in furthering the engagement (Interview N3). In most cases, the collective engagement awakened a thrill of excitement in neighbours, and a sense of power, like David being able to defeat Goliath. In their accounts of the collective engagement to me during interviews, many citizens became quite nostalgic about how it had bonded the neighbourhood, made strangers into acquaintances, or had strengthened the existing relationships made everything "a bit more social" (Interview S2). Those emotions were to be found most in my two Flemish cases (Maarkedal and Drongen) where citizens had been successful in averting the siting of the base station, and in Spijkenisse, where citizens were not successful but did get the support of the municipality. In Maastricht and Nieuwkoop the contested base stations were sited in the end and by the time I spoke to citizens, many had become embittered by their negative experiences with the engagement. Yet, even in those cases, a powerful sense of strength had been present at one stage or another in the engagement process. Because without it, citizens would not have been troubled to sit together and come up with a strategy to change a decision that they felt would negatively impact their surroundings.

Thus far, I have discussed how citizens decided whether to engage and who engaged. For early engagers, the siting of a mast was in conflict with their vision of their neighbourhood or their own business. That was their incentive to dive into the topic and figure out what was going on. They tried to convince neighbours to join the engagement, because early engagers considered a critical mass of support from neighbours crucial to legitimate their concerns. This meant that only a few citizens were very active in the engagement, with the rest of the neighbourhood sympathising with their cause and helping in little ways such as signing petitions and simply keeping the issue alive by talking about it. Once a collective of engaged citizens had been established, the next step was deciding on how to engage with the siting of the base station.

Collectives of engaged citizens came together to discuss the options in actions and procedures. In Drongen, one of them related how this went:

[a]nd then you start to think about how best to respond. What are the possibilities? When you're in a group, more than one strategy is then presented. I remember for example one person saying 'we should go to the city council, let them know how we think!'. Anger. Then it isn't always easy to keep the harmony 
in one group. If you suggest a strategy that is counterproductive, for example, to get into conflict with policymakers, then you ruin it. So it also demands some diplomacy, and strategic insights (Interview D3).

In all of my cases of mast siting controversies, citizens argued and acted alike, even though none of them mentioned it as explicitly as in the above quote. No matter how angry and frustrated citizens were, the way they engaged was always productive, i.e. they worked within the boundaries of the democratic system and the rules of law, pursuing the democratic rights they felt entitled to. Only once did it happen that something unlawful occurred when in Spijkenisse, after the construction work had started for the mast, someone had vandalised some of the material. The group of engaged citizens however was very quick to denounce any involvement in this.

Collective engagement was for and foremost targeted at averting the siting of the base station by way of existing democratic procedures in public administration law. Citizens wanted to either influence the impending decision about the mast siting or change the decision that had already been taken. In both circumstances, citizens turned their efforts towards the local decision-making authority: the municipality. Groups of engaged citizens in Nieuwkoop, Maastricht, Maarkedal and Drongen (Keiskant) set to work to compile a dossier (see Picture 3.5. \& 3.6.) that would result in filing an official complaint with the municipality against the siting of the base station which is called a notice of objection (bezwaarschrift) in Belgium or a submission of their viewpoints (zienswijze) in the Netherlands. In Drongen (station) the construction work of the mast had already started, so a few engaged citizens immediately decided to apply for a temporary injunction to halt the construction work at the court of first instance in Ghent. In Spijkenisse, construction work had also started which meant that filing a complaint with the municipality was too late. Instead, engaged citizens tried to persuade the municipality to withdraw the building permit.

Extra pressure was added by the short time available for citizens to compile their dossiers: 6 weeks in the Netherlands and 4 weeks in Belgium. In Maarkedal, for example, the group of engaged citizens came together for the first time on 10 December, and 6 days later, they handed in the notice of objection. To re-enforce their argument, groups of engaged citizens gathered signatures on the notice of objection via the Internet, door-to-door, at schools or at public events such as soccer games. They also printed ready-made notices of objection in local newspapers for others to convenientIy hand in to the municipality. It served the aim to "show the municipality that it is not just a small group but a big group of people that have comments on the proposal" (Interview M2). Engaged citizens also contacted journalists from the local media who were usually very keen on reporting on the actions, and mostly ended up supporting the engagement "because they love their neighbourhood. They try to protect it with their pen and listen to people who make a stand for something", as someone said in Maarkedal (Interview MA2). Journalists followed the developments closely (for exam- 
ple, going to meetings), included contact information on how to help the neighbours in their articles, published personal comments and generally followed up on the engagement.

Engaged citizens tried to mobilise people they assumed could make a difference, such as local politicians, the major, aldermen or headmasters of schools. In Spijkenisse and Nieuwkoop, citizens used their right to comment in the meetings of the city council and pleaded the politicians present to stop the siting. In Spijkenisse, on a cold morning, a few engaged citizens tied themselves to the base of an electricity pylon in which a mobile phone operator planned to site some antennas (see Picture 3.7.). This pylon was situated in the same park where another operator planned to site a mast, the one that had sparked the citizen engagement in the first place. But actions like these in Spijkenisse - which are more like protest actions - were rather rare, and did not occur in any of my other cases. 

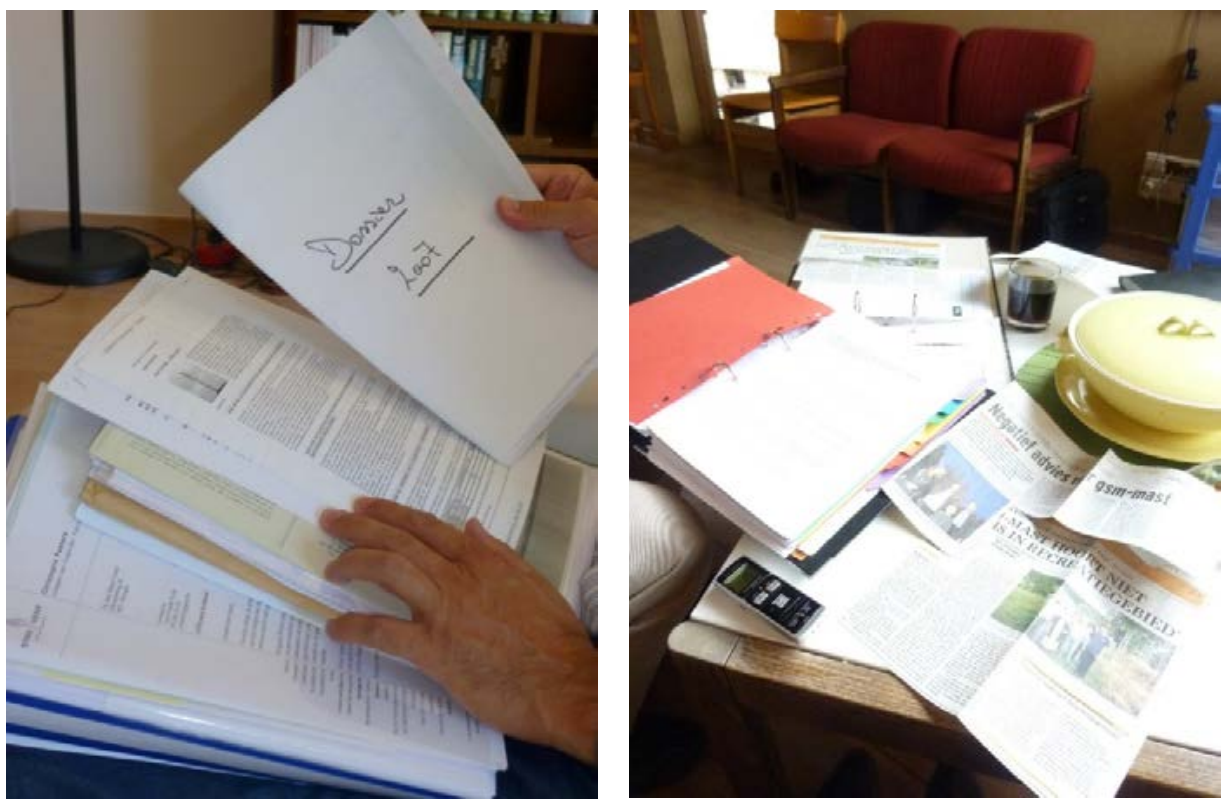

Pictures 3.5 \& 3.6. - Dossiers of engaged citizens in two mast siting controversies. Photographs by author.

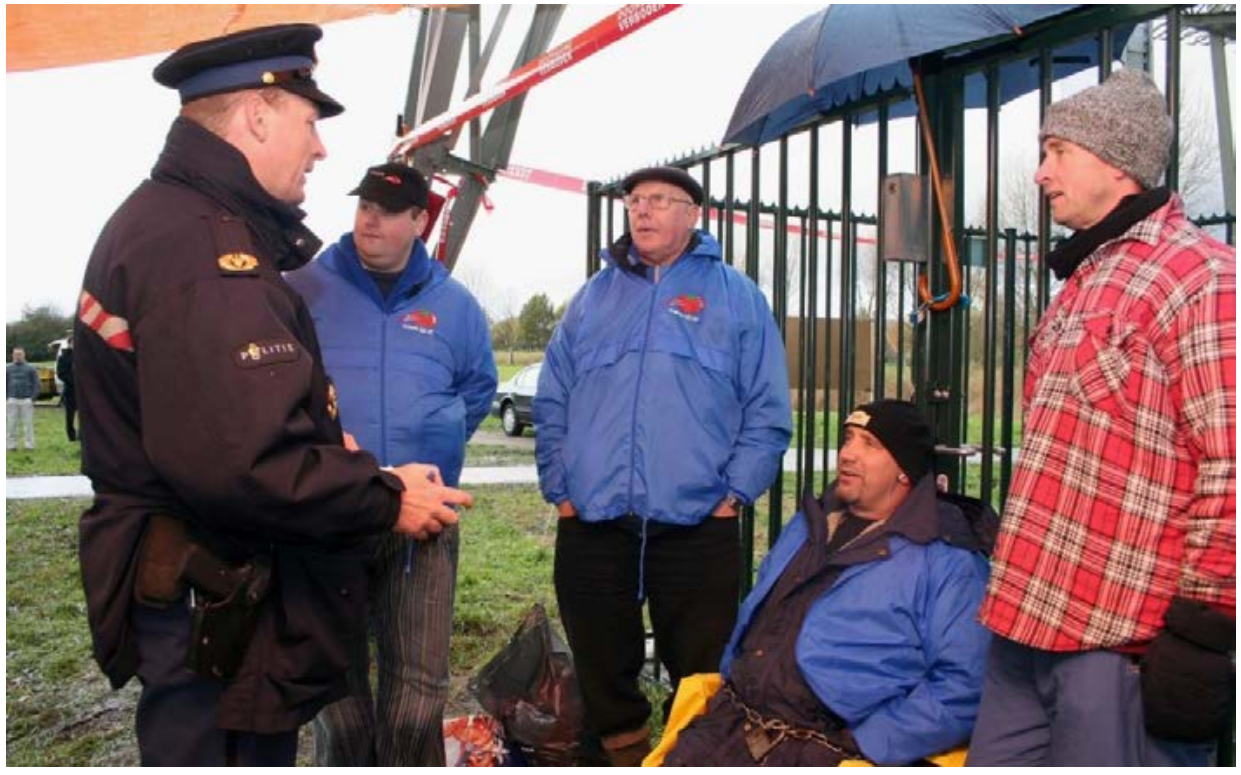

Picture 3.7. - Engaged citizens tied to the base of an electricity pylon in Spijkenisse in which a mobile phone operator wanted to install antennas. Photograph by Algemeen Dagblad. 


\section{Knowledge gathering}

Groups of engaged citizens thus tried to strengthen their notices of objection with the power of numbers, i.e. gathering many signatures and individual submissions of viewpoints, and with the power of networking, i.e. gathering the support of people of influence in their neighbourhood. They also worked hard to put the right arguments into the notice of objection. Finding more information on masts for wireless communication technology and mast siting practices was the first step, as one citizen said: "because you want to have a say in the siting process, you want to gain more and more knowledge" (Interview N3). Collectively engaging in mast siting controversies thus meant collectively gathering this knowledge. In Maarkedal, "[e]verybody contributed - in a meeting people would say like 'I read this', 'I heard that' or 'I saw this TV programme about it'. It was very much alive in the group" (Interview MA2). In any mast siting controversy, there were different reasons for citizens to engage (see Table 3.1. for an example of a submission of viewpoints by the working group in Maastricht):

[i]t's a shame for the recreation. It is not compatible with the character of the landscape. [The mast] would become one of the highest points in Flanders. It does not fit aesthetically in the landscape. And also that it is not good for our health (Interview MA1).

[t]here are three major arguments: one is health, the other has to do with how it looks in the environment, this can really bother people and another has to do with the devaluation of the houses (Interview N3).

I think [people started to engage] mostly because of the visual aspect. A lot of them did not worry about their health but about the school here a few hundred meters away. So people have considered that it might not be one hundred per cent healthy, but also NIMBY [Not In My Back Yard] plays a role. I also have a mobile phone and I know it might not be healthy (...) And the other side of the street will have done it more out of solidarity than anything else. It's a good neighbourhood here (Interview D3).

[t]here are two arguments in the neighbourhood that play a role: first one is health aspects (...) There are some studies that show it is harmful. Fine, we also named them [in the notice of objection] because this was supported by a part of the population. Personally I don't believe it. (...) The second point is that the municipality has an antenna policy with policy about base stations in the city. (...) In it is says as a first point that the visual impact should remain as minimal as possible. [The fact that the mast is so high] has offended me greatly (Interview M2).

Our analysis of 211 Dutch municipalities (see Figure 1.3. in chapter 1) already showed that various arguments circulate in mast siting controversies ranging from concerns 
about health, landscape pollution, devaluation of property prices, technical malfunctions or environmental damage to a general dissatisfaction with the lack of information or participation in the siting process or worries about the quality of the decision-making process or distrust of the mobile phone operators. The groups of engaged citizens thus set to work to collect "all arguments that the group found important against the siting" in order to "translate [these concerns] in the submission of viewpoints", as the group in Maastricht said (Interview M2).

Table 3.1. - Shortened version of the official submission of viewpoints (zienswijzen) of the working group of engaged citizens in Maastricht (Buurtplatform Vroendaal, n.d.).

- The current zoning plan does not allow the siting of the UMTS-mast

- The granting of the permission is (at least partially) is contrary to the 'Antennapolicy'

- The arguments [of mobile phone operator] and municipality are built on shaky foundations (why the mast is needed / why it has to be so high)

- The building application [of the mobile phone operator] could not be inspected publicly and can thus not be taken into consideration

- Inadequate communication of the municipality (we are not taken seriously as neighbourhood c.q. despised)

- Municipality calls visual presence of 40 metre high mast minimal (!)

- Very scant 'Natuurwaardeonderzoek' [ecological value research] (ecological research in an area of merely $10 \times 10$ metres!)

- Considering the surrounding landscape, a mast is unacceptable (no reaction from the Welstandscommissie [building inspector employed to enforce the regulations regarding the external appearance of buildings])

- The presence of a mast can lead to health complaints (if only by suggestion!)

- The mast is located next to a school, a home for elderly and residential houses (requiring a more careful procedure)

- In a mast of 40 metres [the mobile phone operator] can allow other operators (by which [the mobile phone operator] earns money)

- The technological developments go so fast that UMTS will be outdated in a few years

A municipal official in Maastricht was surprised to see that the working group got "to the bottom of these things, to see which objections they can raise (...). Sometimes this is very technical" (Interview M8). But 'being technical' was exactly the aim of the collectives of engaged citizens: a substantial part of the argument was directed at showing the inadequacy of the municipal decision to grant a building permit to build a mast in that particular spot in their neighbourhood. In order to substantiate this claim, it was felt that neighbours were needed "who are well informed or have a background in something, who can deliver substantive knowledge" (Interview M2), as an engaged citizen in Maastricht said, who had a lawyer and someone working in environmental sciences in their working group. In Nieuwkoop, the citizen that initiated the engagement was a lawyer. The group in Maarkedal also agreed that the notice of objection 
should contain technical-legal language: "[y]ou can express yourself emotionally, but you have to show numbers and facts. That's important" (Interview MA1). This was not an easy task, and felt quite daunting for the group in Nieuwkoop: "you dread this, because you have never done anything like it. But eventually you do it" (Interview N3). Also in Drongen (Keiskant), citizens agreed that writing a notice of objection was not simple, because it was almost like a legal document, but "thanks to the large support we had, there were enough people that were well-educated" (Interview D1).

Citizens showed the presumed misgoverning of the mast siting by the local authorities through scrutinising the permit decision and the spatial planning rules. The group of engaged citizens in Drongen (Keiskant) emphasised that "[i]t is important that you speak in the language of the department of spatial planning [dienst stedenbouw], since they will approve or disapprove the dossier" (Interview D1). This meant looking up the zoning plan for the area, since an argument could be made that the mast - an industrial installation - did not fit in a public area, such as close to schools (in Nieuwkoop) or sports facilities (in Drongen, Keiskant), or did not fit in a (preserved) nature area (Maastricht, Maarkedal and Drongen, station). In Maastricht and Drongen (Keiskant) the groups of engaged citizens also argued that the mast did not adhere to the strict building regulations in their neighbourhood. The group in Drongen said:

[i]t is unreasonable to enforce strict regulations for the land division as well as for porches and carports because of reasons of the landscape (...) and yet to allow a mast of 32 metres that is much more disturbing (Citizens Keiskant (Drongen), 2006).

In Maastricht, citizens also had to follow strict regulations on the external appearance of the houses they had built some years ago: "the fences couldn't be more than 60 centimetres, and the colour of the houses was supposed to be cream colour and not white" (Interview M2). They were indignant about the fact that the mast did not have to abide by any of these rules:

[s]o [years ago] you had all these discussions in the neighbourhood. Everyone is eventually very happy but it is still fresh in our memories. Next thing you know they are siting a mast right next to our neighbourhood. What's that all about? (Interview M2).

Questioning the siting of the mast on the basis of spatial planning went hand in hand with proposing alternative locations for the mast to be sited: outside of residential areas, often in nearby industrial zones.

Citizens found it very hard to believe that there was only one possibility for the mast to be sited, and they told that they were moreover very suspicious of the reasons for being so. This suspicion was raised by the perceived financial gains that the mobile phone operator would get from letting other companies use the mast for socalled site-sharing: operators that site their antennas in the same mast have to pay a 
fee to the company owning the mast. Another reason for suspicion was the lack of evidence the mobile phone operator could muster for why the mast had to be sited at all, especially when there were already other base stations in the neighbourhood and no apparent complaints were signalled about mobile phone reception by citizens in the neighbourhood. This was an argument in the submission of viewpoints of the citizen group in Maastricht, who had closely read the mobile phone operators' application for a building permit:

[i]n the page on the situation in Heer [neighbourhood in Maastricht] it says - and not constructively argued with figures - that a mast is needed and that in time it will always be needed. There is a coloured map to illustrate the current coverage. The question is on what is this coloured map based? Where are the closest masts, that are insufficient according to [the mobile phone operator]? Why is a mast of almost 40 metres high needed, one that will eventually only cover a very small area? (Zienswijze ontwerpontheffing/ontwerpbouwvergunning, 2011).

In Nieuwkoop, citizens asked around in the neighbourhood whether there were any complaints and asked for 'proof' of complaints from the mobile phone operator:

[t]hat is what we asked for, if the reception is so bad here, then you surely must have a dossier about it, that there are many phone calls about complaints from Nieuwkoop. Well, it turned out there were no complaints (Interview N2).

None of the citizens, nor the municipality, received information from the mobile phone operator that showed problems with the network and thus the need for a mast. When I talked about this issue to a representative of one mobile phone operator, who was responsible for the siting in Nieuwkoop, he informed me that the operator does not site base stations because of a lack of good reception, but because of a lack of capacity, i.e. the available antennas will not be able to take all calls at the same time (Interview N11). In those cases, he explained, there is no ostensible problem with the connectivity or signal reception yet, but the operator tries to avert problems for its particular customers in the future. As another representative of the same mobile phone operator said: "[w]e don't build for ourselves but for the customer" (Interview M8). From my interviews with mobile phone operators it became clear that they were very reluctant to share information about siting practices because of competition with other operators. ${ }^{13}$ Their default reaction to citizens demanding justification for the siting in their neighbourhood was an economical one, i.e. masts are "the last resort" for operators because they only have downsides as the building of them is a long-

\footnotetext{
${ }^{13}$ When the first base stations for the use of car telephones were sited in the Netherlands in the beginning of the 1990s by the only telecom operator PTT (Staatsbedrijf der Posterijen, Telegrafie en Telefonie), the company was secretive about the number of base stations as they saw it as "company information and thus confidential" (Van een onzer verslaggevers, March 18, 1994). Since the beginning of the 2000s, however, all of the antennas can be found online (antenneregister.nl), and mobile phone operators have to send a plan with to-be-sited antennas to the municipalities.
} 
time, intensive and expensive process (Interview M8). They informed me that, "[i]f we are willing to spend a large sum of money to site a mast, then you can be certain that we think it will pay off. In fact, there is no discussion [about whether masts are needed or not] because these masts are not cheap" (Interview N11).

Engaged citizens thus firstly tried to gather information on the spatial planning aspects of the mast siting to find reasons to criticise this decision. The perceived mismanagement of the municipality did not only remain restricted to spatial planning aspects, but was also targeted at citizen participation in the decision to site the mast. This became particularly manifest if citizens failed in their attempts to be in rapport with the municipality about the need to rethink the siting decision, which happened in Nieuwkoop and Maastricht. An engaged citizen in Nieuwkoop became frustrated by his failed attempts to get the municipality to change their decision by way of petitions, public inquiries at council meetings and conversations with the aldermen of local planning: "[n]ow you have the feeling that democracy was not followed. But the city council, the major and aldermen are there for the citizens, right? But that is an illusion" (Interview N3). He was particularly vexed by the fact that the municipality would not take seriously his views and the siting issue in general:

I think it is grossly underestimated how much [effect] the siting of a base station [has] - it is surely different from constructing a road, or drenching a ditch (...) They [the municipality] thought it was simply like 'We need a new mast, where does the operator want it to be sited? (...) The whole issue with citizens getting involved, I think they see it only as an encumbrance (Interview N3).

A neighbour echoed the same complaint: "[t]he municipality has played a submissive role towards the telecom industry; and has not felt the slightest need to account for its actions to the citizens" (Interview N1). A local politician sympathetic to the citizens' engagement thought it was the municipality's task not only to oblige the mobile phone operators' requests of siting, but also to consider the obligation to citizens to take away uncertainty, confusion, misunderstanding and concerns (Interview N8). Another member of the group in Nieuwkoop was shocked to find out during a meeting with the alderman for spatial planning how little he knew about the issue, whilst she considered it the municipality's task to be knowledgeable in order to make an informed decision (Interview N2). Also in Spijkenisse, this was felt as a serious shortcoming on behalf of the municipality:

[i]t still bothers me a bit that people [the mobile phone operator and the municipality] make decisions without being well informed, just thinking 'this will be OK'. But I think you shouldn't make decisions on the basis of not-knowing, you should first gain more knowledge (Interview S1).

In Maastricht, citizens were also surprised by the lack of participation from the municipality: 
[c]itizen involvement [in this neighbourhood] is very high, but with this decision [to site mast] all complaints have been shuffled aside. This does not match with citizen participation and neighbourhood-oriented works. Citizens' credibility in local politics has already decreased considerably and will decrease further with this decision (M1, 2011).

It is exactly this assumed lack of municipalities' knowledge, communication and citizen participation that spurred citizens in all my cases to find out more information themselves elsewhere, such as in jurisdiction and public administration law.

Still, the municipality was the first contact point for most citizens when they first heard about the intended siting. As one municipal official said: "[i]nitially, you actually get a lot of questions from people" (Interview N6). In Spijkenisse, where a resident contacted the municipality after he heard about the siting:

[b]ack then I called the municipality to ask 'who can tell me something about [the mast]?'. I didn't get an answer. Neither from the city councillors that I knew personally. They had no idea, and said that if an application for a building permit was handed in without anybody being against it, it would simply be granted permission (Interview S1).

For him, the lack of information and knowledge by the municipality, i.e. the authority that allowed the siting of the base station, was a major incentive to dive into the topic, as it was for many engaged citizens:

[t]hen it started to become alive. I thought to myself: I don't agree, one decides upon things one doesn't know anything about, nobody can explain it to me, and yet we all have to accept it. Yes, then you start to dig your heels in. I don't agree, so then I come into action. I just want to know what is going on. And I think [mast siting controversies] all over the country often start like that (Interview S1).

Informed by my case studies, I conclude that citizen engagement with the decision to site a mast was mostly shaped by the perceived inadequacy of the municipality to make an informed decision about the mast siting. Collectives of engaged citizens set to work to understand the jurisdiction and public administration law related to these siting practices in order to unpack the building permit and show flaws in its design. Other concerns about the quality of local government related to citizens' rights of participation and good information.

\section{The argument of 'health risks'}

In their search for information, citizens also came across another argument that often became a forceful reproach towards the mismanagement of the municipality: the possibility of health risks from the exposure to radiofrequency electromagnetic fields 
(RF EMF) emitted by the antennas in the mast. How did they come across the health risk argument?

\section{The Internet: the message of health risks}

In mast siting controversies, citizens made use of a wide network of people who were able to provide them with information or support for their notices of objection: the municipality, local politicians, journalists, lawyers and neighbours with expertise on spatial planning, environmental issues, local politics or previous citizen engagements. These networks were usually very local. There was also another very accessible yet not so local network, which became a source of huge amounts of information: the Internet. All engaged citizens used the Internet, even those that did not know how to use it, asked friends to help them (Interview M3): "[f]irst we searched the Internet for 'GSM mast' for hours and hours" (Interview D1). What did citizens find online?:

[y]ou run into stories that it really is not quite clear what is going on, what the effects are and there are also some frightening stories. And that you can't really argue anymore that that there is nothing the matter. And then you think, hold on a minute, we are talking about my kids (Interview N3).

[s]o I started to read a bit more about it, to get a bit deeper, and then I stumbled upon messages that contradicted each other (Interview S7).

The 'frightening stories' and 'contradicting messages' refer to accounts about detrimental health effects from exposure to RF EMF from base stations or other devices (such as mobile phones, Wi-Fi stations or DECT phones). As another engaged citizen explained about going online: "[h]ealth risks is pretty much the first hit" (Interview M2). When citizens started surfing, they came across several websites solely dedicated to the topic of base stations and health: "[t]here is also a website, a Dutch website on which all sorts of stories and studies are quoted that GSM and UMTS is indeed harmful. We read those and took them into account" (Interview M2). From the mid2000s, these websites highlighted health risks of electromagnetic fields (see Picture 3.8.). Examples of such websites are wegmetumts.nI, StopUMTS.nl, stralingsarmnederland.org (NL), stralingsrisicos.nl, stichtingehs.nl, and beperkdestraling.org (B) (see Table 3.2.). 


\section{UMTS=ZIEKTEVERWEKKER}

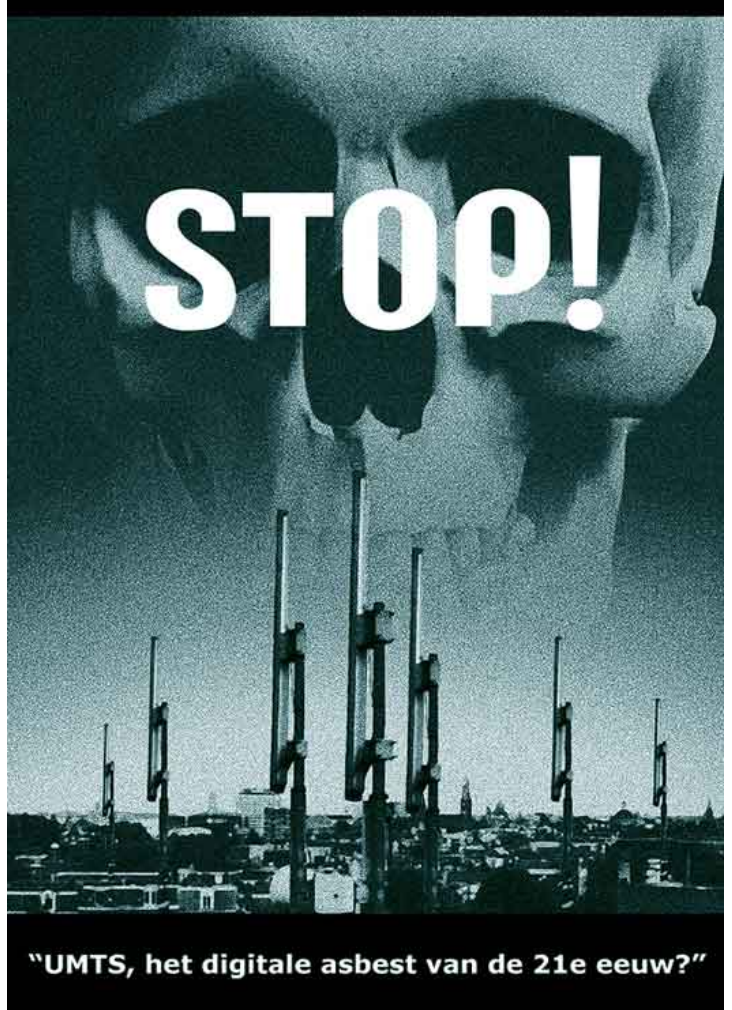

Picture 3.8. - Poster from website Wegmetumts with two slogans: 'UMTS is cause of disease' (top) and 'UMTS, the digital asbestos of the $21^{\text {st }}$ century?' (bottom). Downloaded from www.wegmetumts.nl, on June 7, 2010 (picture is no longer viewable in archived websites from Waybackmachine). 
Table 3.2. - The most important grassroots support teams and other organisations that support engaged citizens in the Netherlands and Flanders.

StopUMTS (NL)

Meldpunt Gezondheid en Milieu (NL)

Dutch Organisation for Monitoring Health and Environment

Nederlands Instituut voor Bouwbiologie en Ecologie (NIBE) (NL)

The Dutch Institute for Building Biology and Ecology

Nationaal Platform Stralingsrisico's (NPS) (NL) National Platform Radiation risks (author's translation)

Stichting Elektrohypersensitiviteit (ESH) (NL) Dutch ElektroHyperSensitivity Foundation (EHS)

Beperk de Straling (BE)

Restrict the Radiation (author's translation)

Stralings Arm Nederland (NL) Low Radiation the Netherlands (author's translation)
StopUMTS is a grassroots support team (mostly) active online. Through its website, it offers a plethora of information on EMF, with a focus on scientific studies. It is often the first point of information for engaged citizens looking for information on siting.

Environmental organisation that strove for a clean and safe environment without pollutants. It recorded cases of environment related health complaints, such as electromagnetic fields. It seized to exist in 2012. For a number of years it received financial support from the Dutch government.

NIBE is the representative of the building biology movement in the Netherlands. It is a consultancy in the area of environmentally friendly and healthy building, of which EMF are part. It also represents a growing profession of woonbiologen: those that measure EMF and other possible indoor 'pollutants' to help people with health complaints.

The NPS is a grassroots support team active online. Through its website, it provides information about EMF and health (www.stralingsrisicos.nl). It grew out of the citizen engagement in Spijkenisse. A few years ago, some of its members started a new organisation, the International EMF Alliance.

The foundation is a contact point, information centre and interest group for people suffering from EHS. Its mission is to accomplish a life as normal as possible for elektrohypersensitive people. It calls for the recognition of EHS as a disease.

Beperk de Straling is a Flemish grassroots support team active online and offline. Its aim is to create awareness about EMF and health. It grew out of the citizen engagement in Drongen.

Grassroots support team that started out as Weg met UMTS (www.awaywithumts.nl - this website does not exist anymore, but old pages can be accessed through the WayBackMachine) but soon became Stralings Arm Nederland. Its aim is to lower the level of exposure of RF EMF because of health concerns. This group is the fiercest and most aggressive in its language compared to the other grassroots support teams. 
Engaged citizens became very familiar with these websites, the most popular being beperkdestraling.org in Flanders and StopUMTS. $n /$ in the Netherlands:

[t]hen we went to look on the Internet and we came across this website of StopUMTS. And there you can read many negative reports. And that was basically the reason to launch some action (Interview S2).

StopUMTS is a site on which to find a lot of information. It collects worldwide information in this field. Both negative and positive. (...) But the important thing is that there are many messages that indicate that it is not good (Interview N1).

[I found information] through StopUMTS (...) it makes you really alarmed. It's really not nice (Interview N2).

[w] got into contact with StopUMTS rather soon. Because a lot of the information comes together there and then you also realise quite soon that this is a problematic issue that plays out with many masts (Interview N3).

These websites showed citizens that they were not the first neither the only ones engaging with a decision to site a base station for mobile communication. This could have the effect of strengthening the engagement such as in Maarkedal where one of the citizens referred to another group in Flanders that had won a lawsuit to prevent the siting of the mast: "this made us feel stronger, like, if we try our best we can also get that far" (Interview MA4). All of these websites served the same purpose, in the words of wegmetumts.nI (awaywithumts.n/): "to offer (forthcoming) activists information about how to try to halt the siting of a planned base station" (Weg met UMTS, 2009a). On that particular website, the information consisted of detailed overviews of a few mast siting controversies, with downloads to notices of objection and letters of complaint to municipalities, mobile phone operators or owners of the plots of land where the mast was (to be) sited. These websites offer a plethora of information on which courses of action to take for collectives of engaged citizens. Apart from providing concrete information on health risks and courses of action, this strengthened the idea of the engagers that it was a good cause, worth engaging with.

StopUMTS, for example, received regular emails to ask what one could do against a mast. It therefore advised several courses of action on its website since 2005, the first one being 'social action': inform neighbours about the plans for siting and about the alleged detrimental health effects. StopUMTS offered ready-made leaflets and flyers to help with that. Secondly, contact the municipality, mobile phone operators, politicians and local press. Also, refer the press to StopUMTS if they had questions one was unable to answer. Thirdly, make the mobile phone operator, the municipality and the owners of the plot of land on which the mast is sited liable for possible future health damage and devaluation of house prices. One could download a form for the insurance claim from the website. Next, convince the municipality that the mast could 
be dangerous so that they can make their own policy on the basis of the precautionary principle. And finally, if one wants to take judicial steps, a particular law firm with experience in these matters was advised, and StopUMTS insisted that it was paramount that evidence and indications in the form of full-fledged papers and studies of health risks should be delivered to the judge who is obliged to look into them. All these papers, which were regularly updated, could be downloaded from their website. $^{14}$

The websites thus proposed various courses of action, informed by the belief that exposure to base stations was dangerous for one's health. StopUMTS.nl and other websites clearly stated that their mission was to "halt the siting of literally ill-making UMTS masts" (StopUMTS, 2004a) by providing a "critical look at the health aspects of mobile communication" (StopUMTS, 2005). In 2007, one could read on the website of stralingsrisico's (radiation risks):

[a] global medical experiment is taking place. The central question in this experiment is: how does the human body react to a lifelong exposure to non-ionizing, high frequency and pulsed electromagnetic fields with weak intensity? Such a medical experiment on a global scale, carried out on hundreds of millions of citizens who are not informed about it, has never been done in the history of humankind! It is contrary with the Dutch constitution and the Declaration of Human Rights (Stralingsrisico's, 2013).

The bulk of information on these websites were scientific studies, papers or proceedings of conferences, i.e. technical documents with professional jargon that served as evidence that there are health risks from RF EMF. Other bits of information were reallife stories of people and animals presumably getting ill from EMF, news on local mast siting controversies, on jurisdiction, and on European and worldwide developments.

People who had also engaged at one point around the siting of a base station in their own neighbourhood initiated most of these websites. They wanted to share their story, help or warn other people who were dealing with the same problem. Others became involved with these websites because of experiences with illnesses that they attributed to exposure to RF EMF, amongst which base stations. The initiator of StopUMTS.n/ for example explained why he set up the website in 2004 (StopUMTS, 2004c): as a healthy person in his early twenties, he moved into a new flat, and soon afterwards started to develop all sorts of health complaints such as heart palpitations,

\footnotetext{
${ }^{14}$ That is what one citizen in Nieuwkoop did when he decided to go to court: he provided the judge and lawyers of the mobile phone operator with a list of documents. As the lawyers of the mobile phone operator told me: "[t]hey came with a pile of reports - they had printed quite a lot and submitted them with the judge. They had clearly emptied StopUMTS.nl!" (Interview N10). The lawyers did not read all of these reports, and neither would the judge, they said. One of the reports however was so recently published that the Gezondheidsraad had not taken it into account in its reviews, so that was sent to them for a quick review. But it did not change the overall conclusion from the lawyers and the judge: the studies the citizens provided were not convincing evidence.
} 
fatigue, dullness, sleeping problems and allergic reactions to food. He searched the Internet for possible explanations, and found some articles about possible effects of electromagnetic fields. This prompted him to buy a high frequency fields measuring device. Inside his flat, there were several spots where the "red lights indicating maximum" went on. He then noticed the many antennas that were on the roof of the hospital across his flat. He briefly considered asking them to shut some down, but then he realised this would be impossible. He moved back to his parents' home, where things went much better, but still he had health problems from time to time. He then also measured the EMF in the house and discovered that the DECT wireless phone was the culprit, as it "transmits 24 hours a day, whether calls are made or not, whether the phone is in the charger or not". He thus managed to find "peace of mind" again, and finished his studies. By exploring the EMF exposure further, he found out that almost all the flats in the city he used to live in had the same height of exposure, this could even be measured on the streets. He decided to come up with an "escape plan" and figured that in some sparsely populated rural areas in France, ensuring UMTS coverage would be too expensive for mobile operators. But then suddenly he had a change of mind: he wanted to "resist this forced emigration". He first contacted the responsible municipalities, but his request to end the rollout of UMTS was unsuccessful. He then decided to start the website StopUMTS.nl "to speed up the process" of "hav[ing] a country that is free of radiation". The website would assist this aim by "summing up the facts and by making accountable the responsible companies, agencies and political parties and calling them to action" (Ibid.).

So, unlike the engaged citizens in mast siting controversies, the stakes were different for the initiators of these websites: they were concerned, not about one particular mast at one particular spot, but about all masts everywhere. Also the tone of voice of the websites was unlike the approach of engaged citizens: it was much more antagonistic and opposing. The websites tried to ignite a sense of indignity and urgency that citizens should rise up against the establishment by way of exposing the scandalous nature of government and industry in mast siting practices. One could read on wegmetumts.nl:

[i]t is of the UTMOST importance that we citizens join forces and form an action movement of hundred thousands of people against UMTS. Only by the power of many people and with actions, protests and judicial measures can we prevent that we are being radiated to bits because of financial gains for a small elite group of industrials, bankers and leaders (Weg met UMTS, 2009b, emphasis in original).

Most websites showed a profound distrust of governments, industry and scientific institutions and organisations. StopUMTS, for example, alluded to the inability to trust the Dutch government when it came to health aspects, as it had also neglected the risks of asbestos and smoking in the past, and now its "hands were stained with blood" (StopUMTS, 2004b). Beperk de Straling claimed that the World Health Organi- 
sation (WHO), i.e. "the point of reference for doctors, scientists, researchers and policymakers", was unscientific because it was financed by the telecom industry (Beperk de Straling, 2008). Wegmetumts devoted one webpage to ventilating its "aversion" against one member of the Gezondheidsraad who was believed to have financial ties with the telecom industry (Weg met UMTS, 2009b). The latter also used provocative slogans such as 'UMTS = assassinator', 'UMTS is the digital asbestos of the $21^{\text {st }}$ century' (see Picture 3.8.) and 'The government: "Wir haben es nicht gewußt?"' (Ibid.). This incendiary rhetoric of conspiracy and negligence by those in power continued for many years. In 2012, a new online platform was established by one self-proclaimed 'radiation activist', called Burgerministerie voor Stralingsbescherming (Ministry of citizens for radiation protection). He proclaimed the year 2012 the year of the velvet revolution, as the call for truth became louder and louder, the lobbies behind manipulative government and telecom organisations were becoming visible and the "unmasking" was believed to be not far away (Burgerministerie voor Stralingsbescherming, 2012).

These websites thus tried to exert their influence on readers in different ways: by informing them about the assumed health risks from masts, by proposing a particular set of social actions and by exposing an overall mismanagement of mast siting. All of this information was imbued with a sense of indignation and sometimes blatent outrage (such as in the case of wegmetumts.n/). The websites served as important impetuses for engaged citizens to continue with what they were doing. It showed that there were many other people concerned about masts; it gave them more reasons to engage as it pointed to possible health risks; it gave 'evidence' for their notices of objection in the form of scientific studies showing harmful effects from exposure to RF EMF; and it fed into already prevailing ideas about the misgoverning of national and local authorities. Moreover, the people behind the websites sometimes also played a role as mentor such as in Nieuwkoop, where someone from StopUMTS.n/ contacted one of the engaged citizens to tell him that he should continue with his actions and not give up, and also gave advice for the lawsuit that the citizen was planning against the siting. Team StopUMTS also posted on the website of the working group in Maastricht: "[f]or the most current and complete information about the health aspects of mobile telephony see StopUMTS.nl" (Team StopUMTS, 2010). So it was hard for engaged citizens actively searching for information on mast siting not to bump into one of those websites and its message of health risks.

\section{Uncertainty and pleas for precaution}

But how did engaged citizens digest the knowledge available on these websites that pointed to a possibility of health risk? How did they value and make sense of it? Some citizens were already familiar with the story of possible negative health effects from mobile phones and masts and wanted to find out the truth behind it: 
[s]o I went on the Internet to find out what actually was true, but it didn't reassure me, on the contrary. I also heard every time that (...) some studies are paid by the telecom companies and then I am not sure anymore (Interview MA3).

This particular engaged citizen found it very hard to make up her mind, and she was not the only one. Citizens talked about the uncertainties in knowledge and the conflicting evidence about the harmfulness of wireless communication technology. Uncertainty and ambiguity were important reasons for them to engage with the siting of a mast:

[b]ecause I think, one is uncertain about these things, there is no certainty. One professor contradicts the other. And my principle is, if you are not sure that it is not harmful, you don't do it, especially not close to children, [hence] close to schools (Interview D4).

[a]s long as it is not indisputably proven that it cannot hurt, you should be careful. That's what it is about. And do not take unnecessary risks. Where you expose people permanently to extra radiation (Interview D8).

[e]specially that there is not much certainty about the consequences. And then I think, if we would be 10 years along the line, and would know more about the consequences and we would know that it is not harmful, then perhaps (...) (Interview MA4).

[a] lot of research has been done but there is not really a definite answer to the question whether it is actually harmful or not. And I think as long as one cannot say with certainty that it is not harmful (...) yes, then I think you better be careful (Interview MA2).

Most engaged citizens were unsure about the existence of health effects from masts, but took into account that there might be negative health effects and thus preferred to err on the side of caution. Only a few engaged citizens were really convinced about health risks. In the explanations of these 'convinced' citizens, they largely took over the rhetoric of the websites, such as StopUMTS.nl: they pointed to scandalous stories about the links between national governments, rogue scientists and industry. They were very knowledgeable on the topic of EMF health risks and conversations with me would turn quickly from a focus on the particular siting controversy in their neighbourhood to a general story about health risks of RF EMF (not only masts). They referred to the latest studies and used jargon such as 'glucoses metabolism' or 'electrocardiograms' to explain the existence of health effects (Interview N1). For most engaged citizens, however, the issue of mast siting was not framed as a definite risk, such as the websites did, but as a possible cause of illness.

Because of the uncertainty, citizens were thus interested in the likelihood of unanticipated consequences. They argued that the uncertainties should lead to pre- 
cautionary measures. The following remarks from engaged citizens in mast siting controversies or those active on blogs illustrate this:

[t]here might not be any evidence that the radiation is harmful, but there is also no evidence that it is not harmful (Engaged citizen quoted in newspaper article Onrust in wijken over UMTS-zenders. Wachten op Zürich, 2005)

[a]re there studies? Can this research show that there are NO harmful effects from this radiation? (Blog post of Swa, 2009 on a radio show about EMF and health)

I would like to reverse the argumentation (demonstrate that it cannot hurt). (Also on the longer term) (Blog post of Rieks, 2009 on a television programme about EMF and health)

Most citizens did not bother to read or understand the scientific studies found on the websites. As one of them said "I didn't read [the reports] completely, nor did I read them thoroughly. Some things are so in-depth, that I think: you can read them and you see letters on the paper but you cannot evaluate it" (Interview N3). The way people made sense of the plethora of information on health risks found online was to weave that information with other forms of knowledge and experience. Concerns about health risks were mentioned more often in mast siting controversies if people were ill or were anxious about the health of neighbours. In Maastricht and Maarkedal, engaged citizens referred to neighbours with cancer who "were not keen on living next to a mast" (Interview MA1). There was also one person concerned about the effects of the mast on his knee prosthetic (Interview M4). These arguments however remained rather marginal within the engagement process in those two neighbourhoods. In Nieuwkoop on the other hand, similar concern about another vulnerable group in society, i.e. children, became the cornerstone of the engagement against the siting. The siting of a base station close to a group of schools was mainly framed in terms of 'health risks' to the youngsters. The headmaster of the primary school explained:

[a]s long as it is not clear that there are risks linked to the siting of UMTS masts in the direct vicinity of the school, we shall forcibly advice the municipality to not site the new UMTS masts on the little plot of land 300 metres away from the school building. One must rule out each risk, especially with a building where a 1000 children get education (Interview N5).

The group of engaged citizens emphasised repeatedly that their "point remains that we are dealing with a vulnerable group, children in this case, who are knowingly exposed. According to us, you should not take that risk" (Interview N3).

The health framing in Nieuwkoop was moreover reinforced by the fact that one of the early engagers had embodied experiences of being electrohypersensitive, i.e. 
he became ill after being exposed to RF EMF. One could read dozens of stories about electrohypersensitivity online, such as the case of the initiator of StopUMTS. Yet, these stories had much more power of expression if they came from an inner circle of neighbours, friends or family. The alderman of spatial planning in Ghent had a son who had experienced health problems due to exposure to EMF sources. The alderman told me he was first sceptical, but became convinced once the source of EMF (a GPS tracker) was taken away and his son recovered completely (Interview D8). He was supportive of the citizen engagement with the siting and urged the city council to forbid base stations siting close to schools, hospitals and elderly homes. Sometimes engaged citizens also referred to professionals with practical experience, such as general practitioners, whose experiences had led them to believe that wireless communication technology might be harmful. By way of appeals (appèls), a number of general practitioners proclaimed that a growing number of patients suffers from health problems that they (partially) attribute to EMF sources. ${ }^{15}$ Citizens in Drongen felt reassured in their engagement by the support of an oncologist from a nearby hospital who became to believe in harmful effects of RF EMF through his experiences in his clinical practice: "those people are not going to put their reputation on the line for nothing. It strengthened our belief in the just cause" (Interview D1).

Information from the websites and from knowledgeable neighbours was thus triangulated with other sources of understanding that people had. Not only personal (embodied) and collective experiences of illness, but also experiences with local and national authorities played a defining role in the engagement. The citizens engaged in mast siting often had experience in engaging with their municipality, the outcome of which had an influence on their relationship with and their views of the municipality. In Drongen, for example, the engaged citizens had already won a case with the municipality about the construction of a highway in the neighbourhood and maintained good relationships with some of the aldermen (schepen). ${ }^{16}$ In Nieuwkoop, citizens were frustrated about the competences of the municipality, lamenting how they had not done a good job thus far. Even if citizens did not actively engage with the municipality yet, their views on how the municipaliy was governed seemed to play a role in their reaction towards the decision to site a mast in their neighbourhood. ${ }^{17}$ Citizens did not engage with the national authorities in the same way, but they had experiences of how governments dealt with issues that might be similar to the siting of base stations. Trust in authorities played a role in how citizens made sense of mast siting. A few citizens made comparisons with asbestos and tobacco (Interviews S1, S2, S7, N9,

\footnotetext{
15 For example, the Freiburger Appel (2002), Hofer Appel (2005) and Barneveld Appel (2006), see www.stopumts.nl.

${ }^{16}$ In Belgium, aldermen are part of the city council. In the Netherlands, they are not (since 2002).

${ }^{17}$ At an information session in Valkenswaard at which I was present, for example, some citizens sketched a very negative image of local politics and claimed that you could only get something done if you knew an alderman (wethouder) personally.
} 
D2 \& MA2). One engaged citizen in Spijkenisse said in an interview for the local newspaper: "[i]n 1968 it became known that asbestos was harmful. The Gezondheidsraad only established legal rules well over 25 years later. That is also the agency that decides now about exposure limits for GSM and UMTS" (Polder, 2005). In Drongen (Keiskant), citizens also made the comparison in their notice of objection:

[t] he comparison with the asbestos issue is clear: there were also no conclusive studies to label this material that was initially heralded as 'universal remedy' as a carcinogenic. A couple of decennia later we (unfortunately) know better! DON'T LET US MAKE THE SAME MISTAKE AGAIN! Medicines are tested as many times as it needs to know all (amongst other potentially harmful) effects. With technological innovations this is apparently not necessary. Try to understand if you can! (D1, 2007: 8, emphasis in original).

My observations yielded that equating the risks from RF EMF with asbestos and tobacco is a favourite trope for those convinced of health risks from base stations (see picture 3.8. and picture 3.9.).
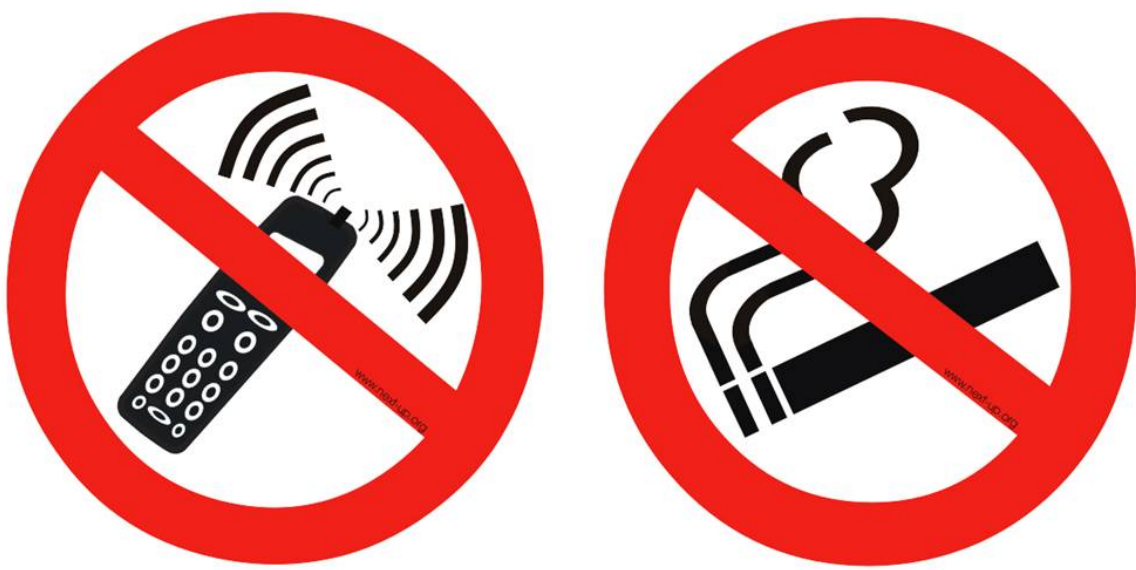

\section{PASSIEVEGSM.STRALING = PASSEEF ROKEN Houd uw afstand}

www.beperkdestraling.org - www.stopumts.nl. - www.next-up.org

Picture 3.9. - Poster from the websites Beperkdestraling.be, StopUMTS.nI and next-up.org with the slogan 'Passive GSM radiation = Passive smoking (Keep your distance)'. Downloaded from http://www.nextup.org/images/logo_passieve_gsm_straling_passief_roken.jpg\#10 on December 12, 2013 
Information about health risks was thus assimilated into a broader landscape of knowledge and experience that citizens already had. But also new knowledge was created that was held against the knowledge found online, as in the case of Spijkenisse where citizens from Spijkenisse against Radiation decided to buy a measuring device to "clarify what [the mast] actually does" (Interview S2, also see chapter 1). After reading stories about health risks online, these engaged citizens became curious to find out how the situation in their neighbourhood was at the moment, before the mast was sited. Through the Internet, they came into contact with someone who did research into environmental illnesses (Interview S1). This person advised them to buy a measuring device to measure the EMF exposure in their neighbourhood, which they promptly did because as one of them said: "I cannot smell it, I cannot see it, but I do want to know it" (Interview S1). They first experimented with measuring in their homes, where they found out that the microwave oven and the DECT phones emitted radio waves. In the streets, nothing could be measured. So they shifted their attention to the flat complexes on the other side of the city that had several GSM and UMTS antennas on the roof (see Pictures 3.10. \& 3.11.). While walking around there residents approached them to ask what they were doing. This contact prompted residents to talk about their illnesses, which they had thus far not attributed to the antennas on the roofs. But if they went to measure in the flats of those who were will, their measuring device signalled higer levels of radio waves, too high, according to the engaged citizens.

The citizens of Spijkenisse against Radiation became scared by these findings: "the stories we read [online], we observed them ourselves. When people said 'I have complaints and problems', if we measured [in their homes], there was quite a lot of radiation. How could that be?" (Interview S1). This inspired the engaged citizens to tackle the issue "in a - between quotation marks - scientific way" (S1). They decided to set up a survey with health related questions, distributed this in one of the flats, recorded radiation, and analysed the results. They were convinced that it was "fairly thoroughly done for a few amateurs" (S1). The results amazed them:

[o]n the side [of the flat] where the antennas were located - where we could also measure it - a higher percentage of tenants had all sorts of weird [health] complaints. On the other side where we had hardly measured any radiation, we also did not receive many complaints back (...) We did it in a very simple but objective way. We simply categorised everything from the front and the back of the flat and now looking at these striking differences. I mean, you can't make this up! (S1).

This newly acquired knowledge left a deep impression on these engaged citizens and convinced them that the stories that they had read elsewhere about people getting ill from exposure to RF EMF were in fact true. The scientific information on health risks was thus assimilated in this broader landscape of knowledge. 

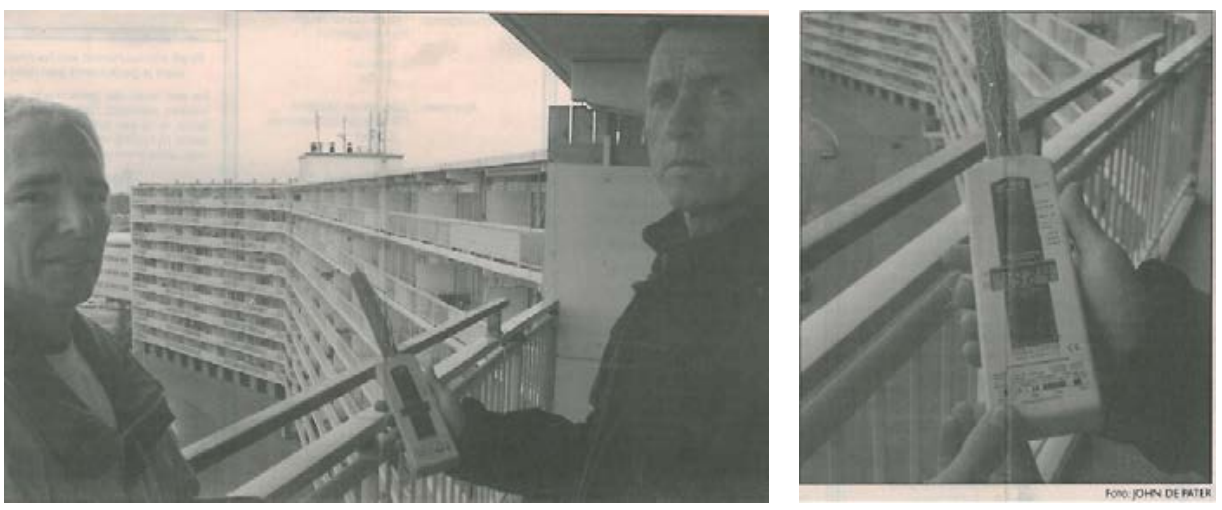

Picture 3.10. \& 3.11. - Two engaged citizens of Spijkenisse against Radiation with their measuring device in a flat in Spijkenisse (source: De Botlek, October 25, 2005. Photographs by John de Pater).

In their search for information about masts and in search for arguments to use in their notices of objections, engaged citizens indefinitely came across the argument of possible health risks. What sort of impact this knowledge had on the engagement process differed from case to case. What all cases had in common was that the notion of harmfulness from masts was appropriated in a landscape of knowledge of those particular individuals and neighbourhoods, which to a large degree shaped its impact. In Spijkenisse, citizens produced their own local knowledge that seemed to substantiate the stories about risks. This was a major incentive for the group to continue their engagement with a focus on safeguarding their neighbours from possible health effects. In Maastricht, on the contrary, several of the engaged citizens were not convinced about the risks, and the argument was thus put alongside many others (see Table 3.1.). It was the same situation in Maarkedal, where from the beginning the mast siting had mostly been framed as a destruction of the landscape and as such as a bad local planning decision. In Nieuwkoop, the personal embodied experiences of one of the early engagers had put health risks on the agenda from the start. The first thing this person did was going around the neighbourhood with a 7-page pamphlet warning his neighbours about the health risks. The fact that the mast would be sited close to several schools added to the focus on health risks. In Drongen (station and Keiskant), one of the engaged citizens became very intrigued by everything he heard about health risks and decided to dive more into the topic. This had its bearing on the engagement, as 'health risks' became a prominent argument in the notices of objection and in the court case. 


\section{The argument of 'health risks': a blind alley}

In any case, the possibility of health risks strengthened the belief for many that their engagement was worth their time and effort and that they should not give up easily. Citizens thus put together their notices of objection, networked and lobbied those in local power, and pleaded the municipality in many different ways to listen to them. Many citizens were left disillusioned when they found out that the municipality did not find their appeal convincing and was thus not inclined to change their decision. Even in those cases where the municipality was supportive of the engagement, such as in Spijkenisse and Drongen, little could be done to alter the siting decision. The possible health risks from exposure to base stations was not a topic that could be discussed with the municipality. This was, for example, evidenced during a public information evening organised by the municipality of Nieuwkoop, which one engaged citizen attended:

[t]his information meeting was very one-sided. Health, that was not under discussion, that was not an item on the agenda, and we shouldn't talk about it at all. Then the whole room lived up, like 'help, what kind of weird comment is that?'. One could only talk about constructional aspects, so about how high, how wide. And that was something we could appeal against. But we thought: whether it's yellow, green or orange, it will never be pretty, and that is also not the point. We are concerned about the health effects (Interview N2).

The municipal official for spatial planning in Nieuwkoop explained that municipalities had to follow the national policy on siting antennas and masts for wireless communication technology. When residents reacted to the siting with submissions of viewpoints that pointed to possible health risks, the municipality's hands were tied:

[w]e cannot do a lot with them because health risks is not something about which the municipality can have its own opinion. There is a clear jurisdiction by now that states that you have to follow the judgement of the Gezondheidsraad and that as a municipality you cannot make something of your own. (...) And so that's what we do (Interview N6).

Also in Maastricht, the alderman for spatial planning said that when citizens hand in notices of objection, this is something they "are quickly finished with, because we simply follow the national policy and that again is based on all sorts of international research (...) that has shown that there is no danger" (Interview M7). Concretely, he said, this meant that the mobile phone operator has to show that the installation adhered to the exposure norms established by the government in order for the municipality to grant the building permit. Another alderman for spatial planning concurred: "radiation is not a topic or item on which we can refuse the siting of a mast. That is determined nationally by The Hague [Dutch national government]" (Interview 
E1). Even if the municipality was supportive of the citizen engagement, as was the case in Spijkenisse, it did not have the means to change anything about the intended siting, as the alderman in Spijkenisse said:

[s]o we did take it seriously, but I've always tried to - like with electricity pylons to have the discussion, well it's not a discussion, because I cannot decide about this as a municipality whether it is dangerous or not. I have to take into account what The Hague thinks, which conditions I have to follow. If The Hague says 'it's safe' or 'it's safe within this distance', well, then I have to work with that (Interview S4).

In Belgium, the municipality is not even the one giving the permit for building a mast, but it gives an advice to the deciding authority, the regional public servant for local spatial planning (gewestelijke stedenbouwkunidge ambtenaar), part of the Flemish government. The municipality is obliged to organise a public inquiry upon which it determines its advice (Departement Leefmilieu, Natuur en Energie, n.d.). In the case of Drongen, the city of Ghent had made its own antenna policy based on conversations with the mobile phone operators and the Flemish region to make sure that their advices would always be followed. The city's advice about not siting a mast close to the houses near the station had not been followed, and it was therefore also supportive of the engaged citizens' legal actions against the siting decision (Interview D6). In the two Flemish cases, citizens won a court case and the base station was not sited. In Drongen, citizens attributed their legal success to the persuasiveness of the scientific studies showing health risks from the technology (Interview D2, D3 \& D7). The judge had ruled out of precaution, they contended. Yet, the legal experts involved argues that this outcome can also be explained by a nearly two-year gap in the Flemish legislation of antennas (Interview MA6, MA7 \& MA8). Mobile phone operators simply did not have any legislation about safety margins to refer to, and this was enough for the judge to rule that the siting permit was not legal (see section The antenna policy: exposure limits and calls for more science in chapter 4). Once legislation was installed in 2010, citizens were unable to win a court case again based on the argument of health risks (Interview MA7 \& 8).

For both Dutch and Flemish citizens (except for this period when there was no legislation), the focus on health risks thus seemed to be unproductive, as it ended in a blind alley. The municipalities' hands were tied, even if they supported the concerns of their citizens. It seemed that the government the citizens had turned their efforts to, was not the one making the crucial decisions. This was done in 'The Hague' (Dutch national government) or on a regional level - some other place where the engaged citizens had not tried to exert their power. In order to understand why 'health risks' had become the dominant focus and a non-issue, i.e. something that did not warrant discussion on a local level, let alone had an impact on the siting decision, we need to take a closer look at the broader political and institutional context of mast siting, 
which I will do in the next chapter. After reporting my empirical findings in the previous sections, I now continue with interpreting these findings in the remainder of this chapter. I particularly focus on three aspects that were prominent in the empirical discussion: collectives of engaged citizens, science in the public domain and the appeal of health risks.

\section{Discussion: understanding citizen engagement in mast siting}

\section{Collectives of engaged citizens}

Citizens engaging with the siting of a base station did not do this on their own. Mast siting controversies cannot be glossed over as actions from "some loner fighting" who has not yet understood that we live in the $21^{\text {st }}$ century. Engaged citizens were not anti-technology, but were well-embedded, highly educated, active and social individuals that tried to get neighbours together to change a decision that they felt would impact negatively on their living environment. This sense of "together we are strong" should not be underestimated (Interview S2). It often was the engine of the engagement. It is something witnessed by other scholars studying citizen initiatives, such as Leighninger (2006) who has worked with many public engagement efforts in the United States. He refers to the concept of 'public happiness' by Hannah Arendt to describe the "kinds of feeling people talk about when they have been involved in democratic governance" such as in setting up a street association for example (Leighninger, 2006: 35). Hannah Arendt was one of the first political philosophers to discuss happiness in relation to politics, in particular in the context of revolutions (Arendt, 1963). At the time of the American revolution (1765-1783), Arendt argued, 'public happiness' meant freedom and participation in political life: "it consisted in the citizen's right of access to the public realm, in his share in public power" (Arendt, 1963: 124). The roots of the idea of 'public happiness' went back to the second U.S. president John Adams, Arendt claimed, who described it as:

[w] herever men, women or children are to be found, whether they be old or young, rich or poor, high or low, wise or foolish, ignorant or learned, every individual is strongly actuated by a desire to be seen, heard, talked of, approved and respected by the people about him (Arendt, 1963: 119).

Arends' and Adams' definition of 'public happiness' captures the sense of collectively engaging that seems to be vital for any engagement that I witnessed in mast siting controversies to really kick off.

In the first step of the engagement process, early engagers wanted to be approved and respected by their neighbours, to know that their engagement was a collective cause worth their effort. Engaged citizens wanted for and foremost to be heard and to be taken seriously by the local authorities who they considered to be (more or 
less) in charge of the siting decision. Often citizens felt that they were not heard and taken seriously, even though they experienced themselves to be more knowledgeable on the issue than the government officials and politicians they contacted. Yet, engaged citizens did not give up easily. The initial hopes of a swift victory might have withered after some time, but in general, they spent an awful lot of time and effort trying to engage. The notion of 'public happiness' might also give us a clue as to why this is so. Leighninger claims that this type of active and engaged citizenship is more than a means to an end: "[w]hen people get together in small groups and large groups to share concerns, make decisions and solve problems, they don't just appreciate the tangible outcomes - they place a high value on the experience itself" (Leighninger, 2006: 35). Some of the cases seem to confirm this. In Spijkenisse, the main engager kept on being active in the neighbourhood and is now a member of the residents' association. In Maarkedal, the engagement sparked an annual New Year's Eve tradition where neighbours gather around a bonfire.

Siting controversies are spontaneous forms of citizen involvement in local politics. No matter which reasons prevailed for citizens to start and continue their engagement - whether it was a concern about their health, about the landscape or about their property values, they were all politically active citizens demanding a good decision-making process about the siting. They were not per se against the mast itself (as many of them did use devices that require antennas for mobile communication), but they wanted the authorities to take thorough decisions, that also weighed in the possibility of risks to health. Citizen engagement aroung the siting of base stations has to be understood as part of a changing political landscape in which democracy is more than just about elections. Traditional forms of political engagement such as voting or party membership have declined since the 1970s, at least in the Netherlands (Verhoeven, 2009; WRR, 2012). Instead, taking part in action groups or demonstrations, signing petitions, contacting media, establishing citizen groups or any other 'unconventional' form of political engagement are on the rise. In fact, by now, they have become quite conventional ways in which citizens try to voice their concerns, anger, and calls for policy change (Ibid.). The French political scientist Rosanvallon (2008) understands these sorts of practices by which society demands transparency of information, participation and political responsibility from its rulers as a new form of democracy, which he calls 'counter-democracy'. One might assume that citizens have become less politically interested, Rosanvallon claims, yet, citizens have shown their political awareness with greater "social attentiveness" that results in "counterdemocratic practices" that "give rise to informal, parallel forms of authority, or corrective powers" (Rosanvallon, 2008: 290-291). I would like to argue that citizen engagement in mast siting controversies can be understood as such a counter-democratic practice. 
Within the changing political landscape, citizen engagement can take different forms such as policy participation, social participation and social initiatives (WRR, 2012):

[i]n the first two of these, policymakers take the lead and citizens are 'allowed' to take part by having their say, for instance, or by acting as volunteers. In the third category, that of social initiatives, citizens themselves are increasingly showing enterprise (WRR, 2012: 11; English summary).

Only the latter (social initiative) is a non-orchestrated form of citizen engagement, of which mast siting controversies are an example. This may at first seem a rather troubling form of citizen engagement, as it may slow down the decision-making process and arguably hinder economic development. Yet, citizens in mast siting controversies acted within the boundaries of the established rules and regulations, such as filing an official complaint. I thus argue that citizen engagement in mast siting controversies can be typified as 'agonistic', a concept I take from Chantal Mouffe $(2000,2005)$ as used by Imrat Verhoeven (2009). Agonistic relations are different from antagonistic. In both relations, there is a 'we-against-them' divide, but in antagonistic relations, this comes down to rivalry as both sides are considered each other's enemy. In agonistic relationships - say between neighbours and the municipality that has to give a building permit for a base station - one speaks of opponents rather than enemies. In the case of mast siting controversies, citizens respected the boundaries of the political system. Opponents acknowledged sharing the same political environment. Simply put, citizens tried to change policy by respecting the rules of democracy and the constitutional state.

In all cases, the engagement was framed by deeper social, cultural and political commitments of the engaged citizens. The personal backgrounds of especially the early engagers were important in determining the course of the engagement. In Nieuwkoop, for example, the experiences of illness of the early engager immediately drew attention to possible health risks. This finding also came back in the case studies of mast siting controversies that I reviewed in the previous chapter (Drake, 2006; Law and McNeish, 2007; Soneryd, 2007), particularly Drake attributed the engaged citizens' focus on health risks to the professional background of one the early engagers. Each community that became engaged had a culture, i.e. "a sense of ongoing practices, habits, norms, identities, and relationships" that sustained engagement against a development that did not fit with this culture (Gibson, 2006: 8). In Maastricht and Maarkedal, for example, neighbours shared the same culture of living in the countryside and the desire to protect it. This sense of neighbourhood culture was critical in transforming the siting of a mast from an individual to a collective concern that the neighbourhood was bothered about.

The groups of engaged citizens that were set up in order to advance the collective engagement have many similarities with what the social movement literature calls 
'grassroots groups' (Tesh, 2000). 'Grassroots' is a term common in U.S. politics to refer to public opinion or individual members of a political party, the most basic or fundamental political level. In social movement theory (also mostly coming from the U.S.), 'grassroots groups' usually refer to a collective of citizens on a local or neighbourhood level that are formed because of some problem in the community, often environmental and planning issues such as a planned landfill or incinerator, or existing industrial activities (Tesh, 2000). ${ }^{18}$ These groups are called grassroots groups, because they are quintessentially local in their connection to a particular area, neighbourhood or a set of streets. The groups are formed by local people, and all of the work is done by them. Becoming part of such a grassroots group is not by an official membership, but by giving one's support. The structure of these grassroots groups is very informal, and people come and go as they please. Endorsement from other neighbours is very important since grassroots groups have no or little budget. In case they want to go to court, money is needed, and then the larger number of supporters literally pays off. Grassroots groups stay together and active as long as they need to, usually disbanding when the goal is achieved or not.

The citizen groups that were formed in mast siting controversies share many of the characteristics of grassroots groups: they were ad hoc, local, open, flexible and temporary. Yet, I prefer calling them 'collectives' or 'groups' of engaged citizens, because the term grassroots is so much embedded in the environmental movement, and I would not want to typify mast siting controversies as primarily environmental issues, even though it has links with the movement. ${ }^{19}$ Citizens in mast siting controversies did not always act out of the same interests, neither were their reasons always about the object itself (the mast). Despite the fact that "every person has his own story, why they think [the siting] is illogical" (Interview MA1), citizens were very much a collective of individuals engaging together.

In the review of social scientific research, we saw that several risk research studies showed a link between high perceived risk and high distrust in regulators (industry and/or government) (and vice versa) (see chapter 2). Also in my case studies, a number of citizens distrusted the (local and national) government, mobile phone operators and (sometimes) scientific institutions and organisations. In Nieuwkoop, citizens especially expressed low trust in the municipality. In all cases, citizens distrusted the mobile phone operators. The websites that engaged citizens turned to further amplified the perceptions of mistrust by relating stories of the mismanagement of the government and referring to previous health scares. According to Löfstedt (2005), 'trust'

\footnotetext{
${ }^{18}$ Also see www.grassrootsgrantmakers.org

${ }^{19}$ For example, the Stichting Milieuziektes (literal translation: Foundation Environmental Diseases) concerned itself with RF EMF as a form of 'pollution' (see section The presumed deficit of scientific knowledge in chapter 5) and Prof. Lucas Reijnders, who instigated public interest in possible health risks from RF EMF, was also active in the environmental movement (see section Wireless communication technology in the public arena in chapter 4).
} 
consists of three dimensions: fairness (defined by a view of the process or outcome as being (im)partial), competence (defined by an evaluation of the process as being (non)proficient), and efficiency (defined by an evaluation of the spending of taxpayers' money in the regulatory process). In the mast siting controversies I studied, fairness and competence were the main aspects that came up. Citizens argued that the siting process was not fair because the mobile phone operators exerted too much influence on the national government, and this ultimately prevented the government from making competent decisions. In all cases, citizens were critical about the decisionmaking process of the municipality, and considered the latter to be simply following mobile phone operators' instructions.

In conclusion of this section, I showed that the collective aspect of engaged citizens was paramount in understanding why and how citizens engaged with mast siting. I argued that mast siting controversies were forms of social and political initiatives actions of counter-democracy - of which citizens were the engine. A few individuals needed to take the initiative, but citizens engaged together and needed the approval of neighbours to justify their actions. They took matters into their own hands without top-down assistance from the state. The idea of public happiness captured the significance that engaged citizens contributed to the engagement. My research seems to imply that the extent to which citizen engagement takes shape depends on the existence of a growing or strongly established neighbourhood culture that binds citizens together.

\section{Grassroots support teams}

Other engaged citizens also played a crucial role in stimulating the collective engagement of citizens: websites of individuals or groups that supported local citizens, but also operated on regional, national and even international levels. Some case study research of mast siting controversies (Drake, 2006; Law and McNeish, 2007; Soneryd, 2007) also showed that the engagement did not remain restricted to the local area, but citizens addressed national government and organisations to find support (see chapter 2). Yet, none of the authors discussed the extent to which these organisations played a role in local controversies, and the impact it had on the engagement. In my analysis, it became clear that these networks played a crucial role in furthering the engagement. The websites did not only give information about possible health risks from RF EMF, but also proposed courses of action to take for the engaged citizens. The literature on social movements can again be helpful to understand the role of these websites. They, or more specifically the individuals behind them, roughly fit the description of 'grassroots support groups' (Tesh, 2000). In the literature on environmental movements, grassroots support groups are a relatively new phenomenon: they "exist to help local organizations" because they "provide information on mobilizing members, running meetings, using scientific data, talking with the media, pressur- 
ing policymakers, and dealing with stress" (Tesh, 2000: 3). They indeed support grassroots groups, not only with information, but also with acknowledging their struggles and fears. Yet, Tesh (2000) also describes grassroots support groups as "run[ning] periodic conferences to bring local activists together" and having "real offices and paid staff", even if it is on a small budget.

In Belgium and the Netherlands, for most of the grassroots support groups concerned with mast siting, this is not the case. The offices are usually in someone's living room or study, and as one of the founders of one the websites assured me once, it might feel like a fulltime job, but it is not a paid one. Even speaking of groups might be overstating it, since it is unclear how many people are actively involved in any of these initiatives, because of all the work that is done behind screens - quite literally in the sense of computer screens. Some of them also seem to be wary to identify themselves: one of the main figures behind StopUMTS preferred to have a telephone interview with me instead of a face-to-face one in the office to ensure the complete privacy of other members. So, it would be better to speak of 'grassroots support teams', as a team can already be more than one person. Overall, it is much more low-key but therefore not less successful. One does not need a real office in order to reach people. Nowadays, people find each other through the Internet, and this has raised the power of these online grassroots support teams immensely.

The contact with the grassroots support teams online had several impacts on collectives of engaged citizens: it informed citizens about possible detrimental health effects from masts, it proposed a particular set of social actions, it exposed an overall mismanagement of mast siting and it served as an acknowledgement of their cause. Through the contact with grassroots support teams, the engagement often became increasingly focused on possible health effects from masts. Citizens were thus interested in the likelihood of unanticipated consequences. They highlighted the uncertainties and pleaded for precautionary measures, such as not siting the masts close to schools or densely populated areas. Consequently, and contrary to the grassroots support teams, engaged citizens did not demand the ending of the siting of all base stations but focused on alternative locations where this particular mast could also be sited.

\section{Engaged citizens' understanding of risk}

The extent to which the argument of health risks from base stations, pushed forward by grassroots support teams, had a significant impact on the engagement depended on the culture of the neighbourhood and the citizens' earlier experience, knowledge and commitments. Numerous studies in the field of Public Understanding of Science (PUS) show that citizens are embedded in a diverse and shifting landscape of knowledge and experience (Grove-White et al., 2000; Irwin and Wynne, 1996; Ottinger, 2013a, 2013b; Wyatt and Henwood, 2006). When having to make a decision 
vis-à-vis technologically complex products, such as the siting of a mast, they rely crucially on judgements of others (personal or institutional, friends or other organisations) and on individual or collective experiences. This may be the experience of having a friend or relative that suffers from electrohypersensitivity, or having several cases of cancer in the neighbourhood that makes one more cautious for extra 'burdens' on the ill-ones. Tesh and Williams (1996) use a different concept, that of 'identity politics' to explain how, in their case, the environmental movement also "(...) bases demands on the lived experiences, common knowledge, and shared values of ordinary people" (Tesh and Williams, 1996: 294). Plough and Krimsky (1987) refer to citizens' own knowledges and experiences as 'cultural rationality' or 'rationality of the socialworld', to compare it with 'technical rationality', which stands for depersonalised technical and scientific explanations:

[b]eyond statistical probabilities and risk-benefit ratios, public risk perception is understood through a distinctive form of rationality, one that is shaped by the circumstances under which the risk is identified and publicized, the standing or place of the individual in his or her community, and the social values of the community as a whole. (...) It is concerned with the impacts, intrusions or implications of a particular event or phenomenon on the social relations that constitute that world (Fischer, 2005: 55).

All these scholars point to the importance of context and relations in understanding citizens' reactions to issues that might involve risks. Also in my analysis, citizen engagements could only be understood as embedded in the local context.

Researchers in PUS have taken an ethnographic approach to find out how information about a new technology and (possibly) about its negative (health) effects is woven into personal lives and how it is constructed during the course of interactions. They have challenged the idea that beliefs about technologies are simply the result of individual cognitive processes (Tulloch and Lupton, 2001; Veen et al., 2011), to be measured by large scale surveys (see chapter 2). Brian Wynne (1996) showed in his well-known case study of the Cumbrian farmers whose sheep were exposed to radioactive soil contamination, that the 'intellectual' understanding of risks (thus how citizens make sense of risk information) is a process of social identity-construction. Social identity, in turn, is a function of social relations, but is never stable since life is rife with messiness, ambivalence and contradictions. In his case study, for example, most farmers believed that the radioactive fallout on the Cumbrian hills came from the nearby Sellafield nuclear reprocessing plant and not from the radioactive fallout from Chernobyl, as government scientists claimed. This belief however was only uttered in interviews with Wynne and his colleagues and not pursued in any official way (Lash and Wynne, 1992; Wynne, 2008). Many of the farmers' family members worked in the plant, thus "to believe that Sellafield was at least partly to blame (...) was potentially to undermine local commitment to the plant and its central role in the local economy 
and society" (Wynne, 2008: 25). Through in-depth interviews with farmers, Wynne came across these different forms of 'private reflexity' (Lash and Wynne, 1992: 7), i.e. people's struggles to reconcile conflicting identities in social networks. In a similar study approach, Sally Wyatt and Flis Henwood (2006) investigated women's understandings of what constituted 'risks' regarding menopause and its treatments. They argued that this understanding changed over time and that, even though women referred to media accounts of the issue, "women's own experiences and those of their friends, neighbors, colleagues and family are often more decisive" (Wyatt and Henwood, 2006: 233). The authors found three ways in which women dealt with the uncertainties associated with health risks from menopause treatments: 1) not engaging with knowledge claims at all, 2) relying on their own embodied experiences, and 3) accepting some future uncertainty.

These studies into the public understanding of science and risk-issues show that the everyday life experiences of citizens is crucial in understanding their reactions to radiation pollution, menopause or mast siting. Mast siting controversies can only be understood, I argue, if one takes citizens' processes of reflexivity (Lash and Wynne, 1992; Wyatt and Henwood, 2006) into account. In the examined cases, the culture of the neighbourhood, the embodied experiences of EMF or other health issues and the experiences of neighbours, friends and family with EMF but also with previous engagements, largely shaped the course of the engagement. This is in line with Timotijevic and Barnett's (2006) and Collins' (2010) studies into public understanding of RF EMF health risks (see chapter 2). They pointed to an array of understandings and experiences people related to in order to form an opinion about RF EMF and possible health risks.

\section{The appeal of the 'health risk framing'}

In my case studies, especially in Spijkenisse, Drongen and Nieuwkoop, a focus on health became stronger as the engagement went on. The few case studies of mast siting controversies that I reviewed in the previous chapter also identified this mechanism, but they did not investigate this in-depth over several cases. My analysis shows, firstly, that citizens did not frame mast siting as a definite risk but as an uncertain risk, that warranted precautionary measures. They were not so much convinced that there were in fact risks related to the siting of masts, but they wanted to take the possibility of risk into account. Secondly, as discussed above, the extent to which the argument of health risk made sense to citizens depended on the neighbourhood culture, the personal views of the early engagers and the landscapes of knowledge and experience in which citizens were embedded.

Thirdly, portraying the siting of masts as an infringement on people's health had the discursive power to create a collective belief that there was a problem and that action was needed to solve this problem. It helped to frame mast siting as a cause 
worth engaging. Thus, in other words, a collective action frame was established. Collective action frame is a concept from social movement theory that denotes the framing of particular issues as problems that have to be dealt with through collective actions in the form of social movements, organised groups or NGOs (Benford and Snow, 2000; Tesh, 2000). In the literature, the organisation of collective action is foremost a discursive process in which framing of meanings plays an important role. The 'uncertain risk' framing can be understood as a rather convincing and successful frame in establishing a collective, for several reasons (compare de Bruijn, 2011). First of all, it has an inherent logic: it makes sense to believe that exposure to RF EMF might make people ill, as it is commonly known that other forms of radiation such as ionising radiation may negatively affect health. Additionally, there is a long-lasting debate about the harmfulness of low frequency electromagnetic fields from power lines, as well as microwaves from radar, ovens and other applications. Secondly, it resonates and activates shared beliefs and values of the importance of taking care of one's health and the health of one's family (especially young ones). Thirdly, it is a message that can be repeated constantly: new studies that demonstrate a link between exposure to RF EMF and illnesses are made available through networks (such as the grassroots support teams) daily, as well as stories about people getting ill and more 'evidence' that industry and government are covering up important evidence. Lastly, it uses linguistic means such as metaphors and comparisons: the comparison with asbestos and smoking are powerful tropes that do not need words in order to get the message of negligence across. It is believed to be a convincing argument towards governments.

A next reason why the focus on health dominated related to the agonistic character of citizen engagement. This had an influence on the means by which citizens tried to influence the policy-making process of mast siting. They were keen to approach the issue in a legal, technical and scientific way - thus finding 'good arguments' that the authorities or judges could not ignore. Those who started a court case, for example, referred to particular scientific studies that reported negative health effects from RF EMF and to the endorsement of the precautionary principle by the European Union. This finding is in line with social movement theory that shows that the appeal of scientific rationality in environmental conflicts is high (Tesh and Williams, 1996; Tesh, 2000). Tesh (2000) claims that even though the environmental movement can oppose pollution in a moral realm, "justified on the basis that exposure violates social values such as personal control, fairness, and community cohesion (...) [it] emphasized science since the beginning of the movement" (Tesh, 2000: 94-95). Irwin and Wynne (1996) explain the appeal of science in citizen engagement because of science's alleged objective and disinterested characteristics: "there is an assumption that science is an important force for human improvement and that it offers a uniquely privileged view of the everyday world" (Irwin \& Wynne, 1996, p. 6). Also in my case study research, I observed the appeal and power of scientific arguments, an aspect I will further explore in chapter 5 . 
To conclude, 'risk' and not least, 'health' can be a powerful concern. Even in those cases where health risks were not the main reason for engaging, citizens would incorporate it into their notices of objection, and would communicate about it to the press and other interested parties. One could claim that arguing around scientific uncertainty is more likely to have impact than trying to argue about local or even personal impacts (such as impact on house prices). In that sense, the rhetoric of 'risks' and 'uncertainty' can be seen as a political instrument used by citizens to try to put certain social problems, in this case the siting of base stations, on the public agenda (compare Borraz, 2008). 

CHAPTER 4

The politics of mast siting 


\section{Introduction}

At a quick glance, all of the mast siting controversies I studied could have been typified predominantly as cases of concern for possible health risks. Indeed, this concern was uttered in newspaper articles, on blogs and websites of groups of engaged citizens and in interviews with me in all of my cases. Yet, diving deeper into each mast siting controversy showed not only that there were many more concerns, but also that these concerns were imbued with a sense of deep dissatisfaction at how the siting had been dealt with by local authorities (see chapter 3 ). Citizens engaged collectively to influence the municipal decision to allow a mast for wireless communication to be sited on that spot. They soon figured out that municipalities in fact did not have much power. Even though municipalities are the ones that either give an exemption decision and building permit to the mobile phone operators (the Netherlands) or an informed advice about siting to the authorities in charge of the permits (Flanders), most of the rules and regulations around siting are decided by national (Dutch) or regional (Flemish) policy and mobile phone company strategies. Engaged citizens found out that it is not the municipalities but another higher authority that determines what municipalities can and cannot do and how much leeway they have in making a company site its base station somewhere else. Municipalities in the Netherlands declared to be "simply following the national policy" (Interview M7) when they refuted the engaged citizens' notices of objection against the siting of the mast, and especially the concerns about uncertain health risks: "radiation is not a topic or item on which we can refuse the siting of a mast. That is determined nationally by The Hague" (Interview E1). As we saw in the last chapter, this led to a paradoxical situation: municipalities were the authorities that citizens turned to, yet their hands were tied by national or regional policies. This meant that municipalities could not accommodate citizens' concerns, even if they wanted; and that the topic of health concerns was not an issue for discussion on this local level.

In this chapter, I discuss why and how this situation could occur by focusing on the interplay of government policies with citizen engagement around mast siting. How did national policies on the siting of antennas develop and shape local policy, and citizen engagement? Who were the main actors involved in shaping this policy, and what was their role? I zoom out from a focus on the engaged citizen and the collectives that emerged around the siting of base stations and instead pay attention to the international and national levels of dealing with the implementation of a wireless communication network: the institutional and political frames. I go back some time to the beginning of the establishment of a wireless communication network in the 1990s, to a time when the mobile world as we know it today was still in the making, and analyse the policy developments (in particular of siting) around this innovative technology. I mainly focus on the Netherlands and its international networks, but also briefly discuss the Belgian/Flemish situation as a point of reference. I discuss the de- 
velopment of wireless communication technology and associated concerns and ideas in different arenas. Firstly, I look at the public arena in the 1990s when stories about mobile telephony started to appear in the media. Secondly, I discuss the expert arena in which experts addressed questions about EMF and health. Thirdly, I analyse the Dutch policy arena in the 1990s during which the government invested in mobile telephony and the first parliamentary questions about the harmfulness of the technology arose. Fourthly, I go through the local policy arena of municipalities' first reactions to siting of base stations. Lastly, I focus on the industry arena and their reactions of corporate responsibility to increasing societal concerns about siting. In the following sections, I dive deeper into the Dutch antenna policy that was established in the beginning of the 2000s as a reaction to the discussions in the different arenas in the 1990s and early 2000s. The government interpreted these discussions, and especially those on the local policy level, as concerns about health impacts from antennas and thus focused on science-based information as a response. One aspect of this sciencebased policy was the provision of risk information to citizens, not through nation-wide campaigns, but through spokespersons such as the Antennebureau and municipalities. I conclude this chapter by summarising what these findings mean in terms of understanding the dynamics of the wireless communication technology controversy.

\section{Wireless communication technology in the public arena: concerns, but no big issue}

In the early 1990s, the development of wireless communication technology was still in its infancy. In the 1980s, it was heralded as a technology that could increase economic productivity by helping business people 'on the go' to be in constant touch with the office (Agar, 2004). It was not until the change from analogue (first generation, 1G) to digital (second generation, 2G) in the 1990s, that mobile phone use really kicked off and became affordable and available for many more people. The United States took a head start: in 1990, there were around 5 million mobile phone subscriptions, five years later this number had grown to 33 million, 10 years later to 109 million (Infoplease, 2007). From the early 1990s, there were attempts to put the issue of health risk from wireless communication technology - focusing on either mobile phones or base stations - on the public agenda. In the United States, in 1992, the topic of health risks from mobile phones first came up for discussion in a lawsuit against a mobile phone operator. Susan Reynard undertook legal action after developing a brain tumour which she believed to be caused by her frequent use of her mobile phone (Nicholson, 2001). Even though there had been cases related to EMF about broadcast towers or military and police radar, this was the first litigation in relation to a mobile phone (Burgess, 2004). 
In the Netherlands, the newspaper NRC Handelsblad ${ }^{20}$ reported briefly on the 'brain cancer lawsuit' in February 1993, with the headline 'Mobile phones cause panic in the U.S.' (Ligtenberg, 1993). The article reported that the story had scared many Americans, who were sceptical of the industry's denials of any health risks from mobile phones. It even had its repercussions on Wall Street, as shares from big companies such as Motorola dropped slowly. After Susan Reynard's husband's appearance on the popular television show Larry King Live, an industry conducted poll found that half of all Americans knew about the lawsuit (Burgess, 2004). In the Netherlands by contrast, there had not been any anxiety caused by the highly mediatised 'scary story', according to the NRC. The article reported that a spokesperson from the then only telecommunication company in the Netherlands, the PTT (Staatsbedrijf der Posterijen, Telegrafie en Telefonie), said that no questions were received about this issue (Ligtenberg, 1993). Three years earlier, the same Dutch newspaper had reported in the same soberly manner on the Americans' concerns about electromagnetic fields in an article about working with computer screens (Köhler, 1990). The journalist was very critical of the American tendency to pay 'disproportionate attention' to harm from technologies, instruments or chemicals compared to harm from human behaviour. As an example he cited the cleaning of asbestos in school buildings, which cost several million dollars but only saves one life per 100 million children: "rationally speaking the money would be better spent on swimming lessons for the American youth" (Köhler, 1990).

It is not until 1994 that we see the first public debate about health risks from wireless communication technology in the Dutch written media. An article in the newspaper Algemeen Dagblad ${ }^{21}$ (n.a., 1994) discussed the concerns of Lucas Reijnders, a professor in environmental sciences, conservationist and policy advisor of the Stichting Natuur en Milieu (Foundation Nature and Environment, author's translation), an influential Dutch environmental organisation founded in 1972 (Parlement en Politiek, 2013). His concerns were targeted at the "poles that the PTT is placing in the whole country for strengthening the network for car telephones". He warned that "radiation" from base stations can cause cancer (n.a., 1994). Reijnders seemed to have been triggered by the publication of two Swedish studies linking living close to high-voltage lines with increased chances of childhood leukaemia. The results of these studies were for Reijnders "reason enough" to argue that it was needed "to take measures now and not wait until a causal connection is proven for a 100 per cent" (n.a., 1994). Reijnders thus projected these new concerns about exposure to base stations into existing debates about possible health effects from the entire electromagnetic spectrum. Placing the activity of base station siting in a wider frame of other EMF risk issues was a way to create larger meaning around the topic. In the opinion article Reijnders alluded to new scientific evidence related to exposure to high-voltage

\footnotetext{
${ }^{20}$ The NRC Handelsblad is considered a quality newspaper in the Netherlands, (see van der Hoeven, 2012).

${ }^{21}$ Algemeen Dagblad is the second largest paying morning newspaper in the Netherlands.
} 
power lines which is part of the EMF spectrum (extremely low frequency or ELF), but is not the same as radiofrequencies from base stations.

Concerns about technologies spanning the wide spectrum of electromagnetic fields date back some time. Before the 1990s, other and older microwave technologies such as radio communication, colour television, computer screens and microwave ovens had prompted some concerns about harmful radiation (Burgess, 2004; Goldhaber et al., 1988; Murphy, 2006; Passchier, 1999; Steneck, 1984). In 1981, in the Netherlands, parliamentary questions were asked about leakages from microwave ovens (Tweede Kamer, 1981). Throughout the 1990s, the Dutch press reported repeatedly on new scientific insights related to exposure to high-voltage power lines (ELF EMF, see Figure 1.1. in chapter 1), but also on a case in which several U.S. soldiers attributed their cancer to earlier exposure to radar (Nieuwenhuis, 1998). At the end of the 1970s, concerns about ELF emerged, first in the United States and then in Europe, and were often linked to concerns about wireless communication technology (Burgess, 2004; Passchier, 1999). The one-man initiative Microwave News, for example, a U.S. newsletter devoted completely to EMF-issues since 1981, has been involved in raising awareness first about high-voltage power lines and later about mobile phones (Burgess, 2004). Also in expert circles, which I will discuss in more detail in the next section, the question of possible risks from RF EMF (such as from base stations) were assimilated into the existing knowledge on other applications of the electromagnetic spectrum, and ELF EMF had already received a lot of scientific attention in the previous years. The Dutch Kennisplatform EMV \& Gezondheid, for example, addressed both RF EMF and ELF EMF issues (see chapter 5). From a scientific perspective, there was a clear link between RF EMF and ELF EMF, even though the interaction of RF EMF and ELF EMF with matter is different. Citizens who wanted to pay attention to base station siting of mobile telephony thus tapped into this rhetoric of ELF EMF and its scientific evidence for a possible link between childhood leukaemia and exposure to electric and magnetic fields.

Eric van Rongen, doctor in radiobiology and scientific staff at the Gezondheidsraad (Health Council of the Netherlands) reacted to Reijnders' allegations (Van Rongen, 1994). Van Rongen claimed that Reijnders got the science all wrong because he mixed up two sorts of 'radiation' ${ }^{22}$ : low frequency electromagnetic fields (highvoltage power lines) and radiofrequent fields (mobile phone masts). Van Rongen stated: "it is scientifically unacceptable to contribute an alleged effect of exposure of one sort of radiation to another" (Van Rongen, 1994). Reijnders countered in another newspaper article that mobile phone masts also emit low frequency EMF and that he was thus "not sure whether we can speak about a safe situation concerning exposure to radiofrequency electromagnetic fields in the Netherlands" (Reijnders, 1994). After

\footnotetext{
${ }^{22}$ Van Rongen writes in his article that 'radiation' is not the correct term, but that he uses it to make things easier to understand.
} 
these three opinion articles, there was no further newspaper debate between the two men, neither a broader debate in the media.

Overall, in the beginning of the 1990s, there was little public attention for health risks from wireless communication technology. Reijnders can be considered the first in the Netherlands to try to put the issue of possible negative health effects from mobile phone masts on the public agenda. He tried to project the siting of base stations into a wider frame of contention, in this case the debates about possible health risk from exposure to electric and magnetic fields. Reijnders claimed to have been triggered to gain more in-depth knowledge about radiation from mobile phone masts by questions from citizens to the Stichting Natuur en Milieu such as 'can these PTT masts be harmful?' (as described by Bröer et al. (2010) on the basis of an interview with Reijnders). However, the newspaper debate did not lead to much more input from citizens. It remained a rather technical discussion between Reijnders as self-proclaimed whistleblower of possible health risks and a staff member working on electromagnetic fields from the Gezondheidsraad. The Gezondheidsraad had put the possible health effects of EMF on its agenda, by its own initiative, partly in order to update advisory reports from the 1970s, so it was not surprising that a staff member of the Gezondheidsraad reacted to Reijnders' warnings. The Gezondheidsraad is (and has been since 1902) an independent statutory advisory body that advises ministers and parliament on the state of the art concerning questions about public health. Ministers and parliament can ask for advice, but the Gezondheidsraad can also give unsolicited advice when it considers a topic of importance (for an in-depth discussion of the Gezondheidsraad, see Bijker et al., 2009). This happened with EMF and health. Its staff members thus became involved with national and international expert bodies on EMF. In fact, discussions about possible health effects from sources of non-ionising radiation were mostly restricted to the expert arena. The articles by Reijnders thus had the effect that the expert discussion on EMF became briefly visible in the public arena. For staff members of the Gezondheidsraad, the issue of health risks from wireless communication technology was assimilated into a larger international debate about the safety of applications of practices involving the exposure to electromagnetic radiation and fields, divided between non-ionising and ionising electromagnetic radiation (see Figure 1.1. in chapter 1 ).

In the Netherlands, in the 1990s, public discussions about wireless communication technology were restricted to a few opinion articles from a professor in environmental sciences who proclaimed health risks from the base stations for the budding GSM-network. The media also paid some attention to other EMF-issues such as radar or high-voltage power lines. The fact that a staff member of the Gezondheidsraad reacted to the opinion articles shows that EMF was a topic in the hands of scientists, and that RF EMF from base stations for wireless communication technology fitted into existing scientific insights about possible health risks from ionising and non-ionising electromagnetic radiation. 


\section{Wireless communication technology in the expert arena: focus on health risks of EMF}

The history of the protection from non-ionising radiation, of which radiofrequency electromagnetic fields is part, is closely tied to the history of protection from ionising radiation. In the early $20^{\text {th }}$ century, protection from ionising radiation became increasingly important after the discovery of its harmful effects. In 1925, the first International Congress of Radiology declared the need for establishing international protection standards. Three years later, the International X-ray and Radium Commission was established - the predecessor of the later International Commission on Radiological Protection - and the first safety recommendations were published (Clarke and Valentin, 2009; International Commission on Radiological Protection, 1928; Lindell, 1996). Initially, the protection of the individual was emphasised. This focus changed after the Second World War, with the nuclear weapons trials and the applications of nuclear energy for electricity production. A new profession of 'health physics' or 'specialists in radiation protection' arose around that time - the Health Physics Society, which is mainly based in the U.S., dates from 1956 - that aimed to protect humans and the environment from detrimental effects of ionising radiation. The exposure limits of the second part of the $20^{\text {th }}$ century were based on the assumption that there is no safe exposure level, thus there is no level that does not entail a risk of genetic defects.

Applications of non-ionising radiation date from the early $20^{\text {th }}$ century. As the practices with possible exposures to non-ionising electromagnetic radiation of fields increased throughout the $20^{\text {th }}$ century - think of radar, electrical appliances and the electricity networks, radio transmitters, microwave ovens, solariums, computer screens and mobile phones and antennas - the question about possible health risks from non-ionising radiation also became more relevant. It has a certain logic that scholarly interest in non-ionising electromagnetic fields mostly came from experts already working on ionising radiation. The international federation of radiation protection societies, the International Radiation Protection Association (IRPA), decided to set up the International Non-Ionizing Radiation Committee (INIRC) in 1977. This latter committee changed into the International Commission on Non-Ionizing Radiation Protection (ICNIRP) in 1992 (International Commission on Non-Ionizing Radiation Protection (ICNIRP), n.d.). Like its counterpart in ionising radiation, the INIRC also proposed exposure limits for non-ionising radiation (Duchêne et al., 1991). But unlike the norms for ionising radiation, for which it was (and still is) believed that there is no safe threshold, at least for cancer induction and genetic effects, the rationale behind the exposure limits for non-ionising is based on the assumption - common in noncancer toxicology - that there is a threshold below which no health effects are to be expected.

In the Netherlands, the Gezondheidsraad advised the government on protection from ionising radiation since 1926 (Gezondheidsraad, 1926). The interest in non- 
ionising radiation started in the 1970s when the Gezondheidsraad prepared several advices on radiofrequency electromagnetic fields, specifically micro meter radiation, optical radiation and UV-radiation (Gezondheidsraad, 1975, 1978). The focus was primarily advising the government about safe working environments. In line with what was happening internationally, some Gezondheidsraad staff working on these advices had expertise in the area of ionising radiation but became increasingly interested in non-ionising radiation. ${ }^{23}$ They were part of a network of professionals working on EMF, such as the Fachverband für Strahlenschutz, the organisation of radiation protection professionals in Germany and German-speaking Switzerland, who also had a group that was actively working on non-ionising radiation (Arbeitskreis nichtionisierende Strahlung, AKNIR). In the 1990s, some staff members of the Gezondheidsraad also had contacts with professionals in the United States carrying out research into radio frequent fields, such as possible health effects of mobile phones or effects of high-voltage lines power lines. This area of research was still in development but the U.S. took a head start. ${ }^{24}$ Informed by the international scholarly debate, the Gezondheidsraad set general exposure limits for RF EMF for the public and workers (Gezondheidsraad, 1997), but did not specifically focus on the exposure from mobile phones or base stations. Internationally, exposure limits for RF EMF were established. The ICNIRP published its recommendations in 1998 (International Commission on Non-Ionising Radiation Protection, 1998), which were endorsed by the European Union in 1999 (The Council of the European Union, 1999). The World Health Organisation (WHO) and the European Union were furthermore funding major international research projects on electromagnetic fields and health risks. In 1995, the European Commission announced the funding of an international epidemiological investigation called 'INTERPHONE', that ran from 2000 to 2005, into the link between mobile phone use and cancer. A year later, the WHO launched the 'International EMF project' that addressed all sorts of EMF, including radiofrequencies from mobile phones. Both projects referred to the rapid development of wireless communication technology and the ubiquitous presence of mobile phones around the world (European Commission, n.d.; International Agency for Research on Cancer (IARC), n.d.).

In the Gezondheidsraad, questions about possible health risks from wireless communication technology, such as the public allegations by Reijnders about harmfulness from base stations, were assimilated in an (existing) expert body of knowledge about the safety of all applications of practices involving the exposure to electromagnetic radiation and fields. Interest in the safety of RF EMF increased when wireless

\footnotetext{
${ }^{23}$ Most of the staff members of the Gezondheidsraad have a PhD degree.

${ }^{24}$ Personal communication Wim Passchier, former deputy executive director of the Gezondheidsraad. This interest in scientific research into RF EMF could have been triggered by the Reynard's lawsuit discussed earlier and by on-going controversy about a high-voltage power line between New York and the Niagara Falls. In addition, in the 1990s, the Wireless Technology Research platform was established in the U.S., sponsored by industry.
} 
communication technology became more prominent in society in the early 1990 s. Radiation protection specialists with a background in ionising radiation also began to focus on non-ionising radiation, as the establishment of the INIRC by the IRPA shows. Even though these are different physical phenomena, in policy terms, the protection against RF EMF is related to the protection against ionising radiation. A number of people and organisations such as the Gezondheidsraad that were in charge of advising the government on protection were active in both domains. I assert that, to a certain extent, the way of thinking about how to deal with applications that expose individuals or groups of people to ionising radiation framed dealing with protection from nonionising radiation. Solutions were thus sought in establishing exposure limits to protect individuals and groups in society. In contrast to ionising radiation, a threshold was identified below which (in general) no risks for health effects (for the public) are to be expected. The effect of the interaction of RF EMF is heating of tissue, which is an effect that is theoretically well understood. It is the basis for today's exposure limits. Until the end of the 1990s, there was hardly any discussion about possible 'low doses' and non-thermal effects. ${ }^{25}$

In the expert arena, the issue of possible health effects from mobile communication was placed in established scientific debates of known and unknown effects of the entire electromagnetic spectrum. Scientists projected the issue into a larger scientific question of the safety of electromagnetic fields, of which RF EMF from base stations was only a minor part. Yet, throughout the 1990s, the scientific interest grew in possible health effects from wireless communication technology and in establishing exposure limits.

\section{Wireless communication technology in the policy arena: technology push}

In the policy arena, the primary interest was in the economic potential of the technology. From the early 1990s, preparations were made for a law on telecommunication services, in pursuit of the liberalisation of the market for telecommunication networks and services (Ministerie van Economische Zaken, 1998). Debates preceding the law in parliament ${ }^{26}$ focused on licences and market competitiveness. In a deliberation of the law in 1998, a member of parliament applauded the Minister of Economic Affairs' efforts:

[l]ast year the investments in information technology and telecommunications grew faster in our country than other West-European countries. That is of great

\footnotetext{
${ }^{25}$ This changed throughout the 2000s. Concerned citizen(s) (groups) and some experts are known to criticise the exposure limits on the basis that they only protect against thermal effects. The discussion then focuses on the possible existence of low-exposure non-thermal effects (see chapter 5).

${ }^{26}$ These debates took place in the Tweede Kamer der Staten-Generaal (Lower Chamber or House of Representatives), which together with the Eerste Kamer (Upper Chamber or Senate) make up the Dutch parliament.
} 
importance, because this sector is crucial for the growth of employment and because optimal telecommunication facilities are the most important conditions for the establishment of international companies (Tweede Kamer, 1998).

The law thus provided a framework for the optimal use of this new and booming technology that was believed to bring great economic benefits to the country and to its citizens in interconnecting them all. In the policy arena, attention was thus focused on the 'goede kansen' or 'opportunities' of the technology (WRR (Scientific Council for Government Policy), 2010).

In 1997, the Vaste Kamercommissie van Verkeer en Waterstaat (Parliamentary Committee of Transport, Public Works and Water Management) asked a number of questions about the health safety and nuisance of electromagnetic fields (Tweede Kamer, 1997). The parliamentary committee explained that parliamentarians had regularly received signals from concerned citizens about the influence of radio waves from radio transmitters, GSM base stations, mobile phones and electromagnetic fields from power lines. The committee sketched a situation of scientific uncertainty, by referring to scientific studies "that mention possible effects (...) on genetic material (...) and the occurrence of cancer" and the 1997 Gezondheidsraad report that concluded that exposure to certain EMF could have a negative influence on health in certain circumstances. The committee therefore asked whether there was reason for "extra caution" (Tweede Kamer, 1997). The committee further had questions about the spatial planning aspects of base stations: what if exposure limits would become stricter in the future, how would that affect existing base stations and what policy options did the ministry have? The response of the Minister of Transport, Public Works and Water Management was one of general reassurance. It claimed that, based on the advices of the Gezondheidsraad, it was not to be expected that exposure limits had to become stricter in the short run. However, the minister also acknowledged the increasing public concern about siting practices. It announced to deal with the "increasing public interest in possible health risks" by way of intensification of interdepartmental cooperation and by 'keeping a finger on the pulse': "[w]e will keep up with the scientific developments in the area of health effects of electromagnetic radiation so that the policy can be changed in case of new insights" (Tweede Kamer, 1997).

The government thus tackled the kwade kansen or 'bad chances' (WRR, 2010) of the wireless communication technology by referring to the expert arena. The government used the Gezondheidsraad and its advices as arbitrators, i.e. the government stated that scientific knowledge would be decisive in changing its policy. The issue thus remained open as the government promised to keep an eye on new scientific developments - by means of the Gezondheidsraad. With this position, the government tied the policy arena and the expert arena together. It was, however, not the first time the government had reacted to concerns about base stations by taking re- 
course to the expert arena. In their letter, the parliamentary committee referred to public discussions in three so-called transmitter conglomerates, i.e. neighbourhoods that lived in close proximity to several radio transmitters (ANP, 1996; Ritsema, 1996; Van Dinther, 1996). Since the late 1980s, residents of one such village, Zeewolde, had complained about technical interferences with household equipment but also raised concerns about their health. By then, the government also reacted in a reassuring way: the emitted fields were within the safety standards proposed by the IRPA (Tweede Kamer, 1988a). Further scientific research into the influence of radiation on the health of the residents was not considered needed by the Dutch government (Tweede Kamer, 1988b). Yet, in 1996, in response to continuing complaints from residents in Zeewolde about headaches, concentration problems and fatigue, the $\mathrm{Ge}$ meentelijke Geneeskundige Dienst (GGD, Community Health Services) performed research that concluded the case, according to the government, as it did not show a causal connection between the health complaints and the radio frequent electromagnetic fields of the transmitters (Tweede Kamer, 1996).

I conclude in this section that, in the 1990s, the Dutch government focused on creating policies that enabled the development of wireless communication technology. When questions arose about possible health risks from RF EMF (also from other applications such as radio stations), the government responded by referring to its scientific advisory body, the Gezondheidsraad. According to the ministry, the Gezondheidsraad did not find any evidence for health risks from RF EMF, but would keep a close track of scientific developments. The government thus responded in a reassuring way and promised to keep an eye on future scientific developments.

\section{Wireless communication technology in the local policy arena: dissatisfaction with siting practices}

Despite the government's referral to increasing public anxiety about possible health risks from wireless communication technology in its 1997 responses to parliamentary questions, it was not the case that citizens were only concerned about their health in relation to base stations (see chapter 3 ). Not just citizens, but also municipalities felt taken by surprise by what they considered as questionable interventions in spatial planning. In 1995 and 1998, the government auctioned several licences for GSMfrequencies, and in 2000, for UMTS. Telecom operators thus soon began to develop their networks by siting numerous base stations. There were two incentives to do this quickly: mobile phone operators had spent a lot of money on the licenses, and they were obliged to provide nationwide coverage in a few years, or "in a punishing pace" as some media typified it (Köhler, 1999; Lammerse, 1999)_ENREF_18. One newspaper journalist compared the siting process to a war: "[i]n the fight for the billion market of mobile phones, the new providers elbow each other out of the way to occupy the country with an army of base stations" (Wittenberg, 1999). The article continued by 
explaining that in times of war, rules, etiquette, scruples, or forms of participation are impediments that slow down the march. The journalist had spoken to tenants of blocks of buildings who complained about the siting of antennas on their roofs. The telecom operators deemed high buildings a perfect location for their antennas. Moreover, antennas were attractive for flat owners, because they could "rent out the roof of their tenants for good money" However, tenants felt "taken by surprise when French and English speaking mechanics start drilling on the roof unannounced" (Köhler, 1999). In another newspaper article a tenant uttered the same complaints: "[i]t should be impossible that the landlord who is used to sending around letters about every little colour on every little door (...) now all of a sudden sends up a team of contractors up on the roof unannounced" (Köhler, 1999).

The presumed economic, profit-driven aspects of wireless communication technology - the money flat owners make, the profits of telecom operators ${ }^{27}$, and the incomes the government generated with the sale of licences - were a common theme in mast siting controversies. As one person phrased it in a newspaper article about citizen engagement in a mast siting controversy in Spijkenisse: "the reason why the government does not intervene is because of the money that is involved" (Polder, 2005). A blog post on a website dealing with a local case of mast siting called 'no mast here' was even more specific: "[t]he government has sold the UMTS-licences for about 3 million euro and cooperates with the operators to build over the Netherlands with base stations. According to that same government, there are no health risks (...) How careful! What a coincidence!" (n.a, 2009). Also in the online platform called Burgerministerie voor Stralingsbescherming (Ministry of citizens for radiation protection) the opinion reigned that "all health interests are being sacrificed to the economic development" (Burgerministerie voor Stralingsbescherming, 2012).

At the end of the millennium, the "surprise attacks" of the mobile phone operators (Wittenberg, 1999) - in the journalist's war analogy - led to feelings of discontent, mistrust and resentment amongst tenants of high buildings and municipalities. Some local authorities had become frustrated with the uncontrolled proliferation of antennas (wildgroei). They had no overview of how many base stations there were in their city, neither where or how many more to expect. Some tried to remedy this spatial planning problem by regulating the siting of base station with building permits. Other municipalities wanted to accommodate their citizens' concerns about health risks by prohibiting the siting of antennas on residential areas, hospitals, and nursing homes. In my case studies, which all occurred in the mid-2000s, the municipalities

\footnotetext{
${ }^{27}$ Indeed, the telecom industry was generally perceived as wealthy. Yet, it is important to make a distinction between the producers of mobile phones and other devices such as Apple, Samsung or Nokia and the telecom operators that provide wireless services and are responsible for siting base stations such as TMobile or KPN. In the Netherlands, the telecom industry was made up solely of these operators, who found themselves in financial difficulties throughout the 2000s (e.g. because of the purchasing of expensive licenses for the use of frequencies, see later in this chapter). This is important to note because manufacturers are not an actor in siting controversies, but telecom operators are.
} 
also tried to develop their own policy. Only one of them, the Flemish city of Ghent (of which Drongen is a formerly independent municipality) was successful in installing their own antenna policy with guidelines about siting: putting antennas together on existing masts, bridges, and electricity pylons and preventing siting close to schools, hospitals and elderly homes. This policy originated from both an urban planning (after the antennas for television were taken away, the city did not want this kind of proliferation anymore) and precautionary perspective (because of uncertainties about health risks). The policy could not be enforced, but the city made agreements with each mobile phone operator and the guidelines are usually followed (Interview D6). The city council in Maastricht and Nieuwkoop also had a local antenna policy, but this was mainly a recapitulation of the Dutch national antenna policy (see section From technology push to national antenna policy in chapter 4), with a few adaptations, for example, about how to communicate about siting to neighbours. As I will discuss later in this chapter, there was not a lot of flexibility for Dutch municipalities to make their own local antenna policies, as the national government prescribed the rules and regulations.

Nonetheless, at the end of the 1990s, when mobile phone operators started to site antennas all over the Netherlands, some municipalities sought more influence on the siting process. In 1999, the municipality of Dordrecht, for example, established an antenna policy that took into account local planning issues but also fear for health risks (n.a., 1999a). The fact that the Gezondheidsraad claimed that there was no evidence for the existence of health risks, did not take away the unrest, according to the municipal official responsible for spatial planning in Dordrecht (Municipal official Dordrecht, personal communication, August 2, 2012). A number of municipalities copied this antenna policy: Haarlem, Utrecht and Amsterdam. Also the city of Haarlemmermeer demanded that each antenna or mast needed a building permit, making around 40 base stations 'illegal' overnight. This new policy primarily aimed to tackle the increasing destruction of the landscape, which the city council considered an impairment of the enjoyment of residence for its citizens. The municipality stated that it was willing to cooperate with mobile phone operators in order to ensure nationwide coverage, but only in a responsible way taking into account urban planning and social demands (Haarlemmermeer.nl, 1999a). In addition, some landlords became more reluctant to site antennas on their roofs because of tenants' complaints. In the spring of 1999, one telecom operator was forced to take several antennas off the roof of a flat after tenants complained of health problems. The housing corporation owning the flat did not want to take any risks and ended the contract with the operator. It announced that the antennas could only be placed back on the roof if "it was conclusively proven that GSM-antennas are no danger for the national health" (Lammerse, 1999).

At the end of the 1990s, municipalities sought to influence the emerging and unregulated activity of base station sitings that took place on their territories. The 
municipalities were especially concerned about the uncontrolled proliferation of antennas and some wanted to take precautionary measures because of the possibility of health risks. It did not take long before mobile phone operators and the national government reacted to these local developments.

\section{Wireless communication in the industry arena: social responsibility}

Telecom operators became increasingly concerned that the rollout of their networks would be slowed down if more municipalities and property owners would become reluctant to allow the siting of base stations. With an average sale of 300.000 mobile phones per month, and with high competition on the market because of three new mobile phone operators, demands for qualitative national coverage were high (n.a., 1999b). The telecom operators believed that the "wild-west stories" about health risks - as one telecom operator official called it - were to a large extent responsible for the reluctance of building owners to allow base station siting (n.a., 1999b). It was thus not surprising that the operators challenged the city of Haarlemmermeer's new siting policy to declare most of the antennas in the city illegal in court. For the operators, it was astonishing that the judge in administrative law ruled in favour of Haarlemmermeer, i.e. GSM-base stations did in fact need a building permit (Haarlemmermeer.nl, 1999b). In 2001, The Council of State confirmed this judgment. For telecom operators, this ruling seemed dramatic as they retained that "municipal officials would start dictating where base stations are the be sited", leading to "great gaps in our coverage" (Lammerse, 1999).

The then five telecom operators of the Netherlands reacted by joining forces and establishing MoNet (Mobile Network Operators the Netherlands) in the summer of 1999 (MoNet - Mobiele Netwerkoperators Nederland, 2000). ${ }^{28}$ The aim of MoNet was to become a central information service about the safety of the technology. To show the industry's concern about "the nature and scale of reports that allege to health risks from GSM-antennas" (Ibid.), it set up a website and a free telephone number for inquiries about antennas, published brochures (the first one titled 'GSM-antennas for mobile communication: safety comes first') and coordinated a 'national information service brigade' that gave presentations about GSM-antennas to municipalities, residents' associations or other interested parties. With MoNet, the operators could act as one voice in contacts with the authorities. The first action was to hand over a newly agreed code of conduct about the siting and maintenance of base stations to the Minister of Transport and Public Works in which it was stipulated how the operators would work together and with the municipalities in realising sufficient coverage (MoNet - Mobiele Netwerkoperators Nederland, 1999a). MoNet also tried to convince

\footnotetext{
${ }^{28}$ The same initiatives took place in other countries such as in Germany where the Informationszentrum Mobilfunk (The IZMF Information Centre for Mobile Communications) was established in 2001.
} 
municipalities of the operators' new 'siting etiquette' by addressing them directly at conferences organised for municipal officials by the Vereniging Nederlandse Gemeenten (VNG, Association of Dutch Municipalities) (MoNet - Mobiele Netwerkoperators Nederland, 1999b).

Whatever its message, MoNet was keen to emphasise the operators' social responsibility in providing a good network. In its speech to the VNG it referred to the immense popularity of the mobile phone as a gift for mother's day, Christmas or Sinterklaas (Saint Nicolas Day) to point out that "the Netherlands chooses massively for mobile communication" (Ibid.). Throughout the 2000s, the operators continued emphasising the 'opportunities' of the technology as a societal good, sometimes even a necessity. In 2011 in Valkenswaard, a representative of the operator that was planning on siting a mast, opened her presentation at an information evening for residents with a newspaper article about the 2010 earthquakes in Haiti (participant observation Valkenswaard). A man that became trapped under the debris had been able to safe himself by looking up the necessary techniques online with his mobile (participant observation Valkenswaard). Operators also related to me during interviews that the technology "serves a great societal need to stay mobile". I was informed that emergency services, the police, the fire brigade all use it, "sometimes it is said that it harms your health, but it can in fact safe lives" (Interviews M9 \& N11).

The mobile phone operators reacted to increasing concerns about base station siting, and especially the 'restrictive' local antenna policies that a number of municipalities developed, by joining forces in MoNet. Its goal was two-fold: to increase the awareness of the perceived necessity of a wireless communication network and to convey an attitude of professionalism towards municipalities. Just as the mobile phone operators, the national government's reaction to the societal concerns about base station siting also mainly focused on the problem of lack of siting locations. It sought to remedy the problem by establishing a national antenna policy.

\section{From technology push to national antenna policy}

The government shared the operators' sense of necessity of wireless communication technology. It quickly reacted to the concerns on a local level by drafting a new policy on siting antennas and masts (Tweede Kamer, 2000). In the previous sections, I discussed how the siting of antennas raised several issues concerning local planning, health and economic investments. All of these issues needed to be addressed in the antenna policy. Different departments, with the Ministry of Economic Affairs as the initiator, drafted the policy. The focus on the economic potential of a mobile network became the starting point of the antenna policy. The Ministry of Economic Affairs was (is) responsible for handing out permits for the frequencies that are needed for wireless applications. Moreover, since 2002, the Agentschap Telecom (Radiocommunications Agency) is part of the Ministry of Economic Affairs as the safety inspector of 
antennas. The Antennebureau (Antenna Bureau) is also part of the Agency. The Ministry of Transport, Public Works and Water Management and the Ministry for Housing, Spatial Planning and Environmental Management were responsible for the spatial planning aspects of antennas (the two departments merged in 2010 to become the Ministerie van Infrastructuur en Milieu, Ministry of Infrastructure and the Environment). The Ministry of Health, Welfare and Sport was (is) responsible for the healthaspects of the antennas. The Ministry for Social Affairs and Employment was (is) also involved concerning legislation for employees who come into contact with EMFsources.

The local antenna policies that the municipalities of Dordrecht, Haarlemmermeer, Amsterdam and others had drawn up were not implemented for long, because, in the words of the municipal official responsible for spatial planning in Dordrecht:

it apparently led to a too big constriction of the rollout possibilities for the networks, because within a very short time, the government made new regulations that side-lined the municipal policy. This did not really improve the [citizens'] trust in the government (Municipal official Dordrecht, personal communication, August 2, 2012).

Early 2000, the Minister of Health, Welfare and Sport sent a letter to all the GGD'en in which he sketched the current situation of societal reactions to the siting of base stations. It addressed the media attention on possible health risks, and the change of attitude in many municipalities towards base station siting from a laissez-faire to a strict policy, according to the ministry often based on the assumption of health risks. In the letter, the minister announced the plans for a new antenna policy and its recent decision to follow the exposure limits for RF EMF as set by the European Union in 1999 (The Council of the European Union, 1999), which were based on the 1998 ICNIRP recommendations (International Commission on Non-lonising Radiation Protection, 1998). These exposure limits were in line with what the Gezondheidsraad had recommended three years earlier (Gezondheidsraad, 1997). The minister explained that "de facto this means that if the electromagnetic field strengths remain below the European recommendation, a building permit cannot be refused on the basis of health reasons" (Ministerie van Volksgezondheid, Welzijn en Sport, 2000). The minister thus ensured that municipalities were restricted in making their decisions on whether or not to give permission to site base stations.

At the end of the year 2000, the antenna policy was ready. In a letter to parliament, the Ministry of Transport and Public Works and Water Management wrote:

[t]he Netherlands is running ahead in ICT developments. To maintain and preferably consolidate this position a good wireless infrastructure is indispensable. The recent rise of antennas has, however, led to questions from administrators and the public. In specific, there is a lack of clarity about spatial planning and public 
health. At the same time, operators are confronted with a lack of places for siting (Staatssecretaris van Verkeer en Waterstaat, 2000).

The government identified several 'bottlenecks' to the siting of antennas pointing to three relevant actors: local authorities, mobile phone operators and citizens. The government assumed that municipalities did not have enough information (about the technique, health, policies, environmental planning and jurisdiction) to define their own policy. Moreover, the policy of many municipalities had arguably a very ad-hoc character, initiated by incidents and fed by societal unrest rather than based on "actual, objective information and national guidelines" (Tweede Kamer, 2000: 8). Frictions existed between the telecom operators and municipalities, according to the government, because the former were very quick in siting antennas, sometimes even before permits were given, whilst the latter often felt 'pressured' or 'taken by surprise' by the operators. There was also an increasing administrative burden on both municipalities and operators. Because some municipalities implemented a restrictive policy on siting base stations or postponed decisions, it was believed that operators were behind schedule in realising their networks, leading to economic losses. Due to the presumed lack of siting locations, there was also a lack of 'healthy' competition amongst operators which was deemed important by the government. The last bottleneck identified by the government was an increasing social unrest, which the government attributed to concerns about possible negative health effects and about the well-being of citizens living in close vicinity to antennas. According to the government, these upheavals had put great pressure on local authorities.

The new antenna policy was drafted with the objective to tackle all these problems by "stimulat[ing] and facilitat[ing] enough locations for antennas within clear frameworks of health, environment and safety" (Tweede Kamer, 2000: 10). The rollout of the technology was portrayed as an economic and even social necessity. Throughout the policy document, references were made to the "great societal need" for "a swift rollout" of wireless communication networks; citizens and companies wanted "an ever increasing communication capacity" and had "high demands for the speed by which they can communicate" (Tweede Kamer, 2000: 7, 8 \& 10). In parliamentary debates, one politician even spoke of a "moral obligation to do everything in power to rollout as quickly as possible" (Tweede Kamer, 2001b: 6). The antenna policy came into force in 2002 when the national government, the VNG and the (then) 5 telecom operators signed the antenna covenant (Staatssecretaris van Verkeer en Waterstaat et al., 2002). The covenant stipulated that 1) operators needed to provide municipalities with a 'siting plan' (an indication of where in the future the operators plan to site base stations), 2) base stations below 5 metres were allowed to be sited without building permit, 3) base stations between 5 and 40 meters needed a light building permit, 4) operators needed to work together and share masts (site-sharing) and 5) tenants had to consent to the siting of an antenna on the roof. With these new 
regulations, the government secured the swift rollout of the technology and particularly its new generation.

In parliament, the discussion on the new policy focused mostly on the rights of tenants to decide on the siting of antennas on high buildings, the need for information for local authorities and citizens and the need for more scientific research into possible health effects (Tweede Kamer, 2001b: 11). There was little discussion on the role of local authorities. One politician commented that the antenna policy referred to municipalities in a condescending way: "[t]hey don't know what they are talking about and should not get too much power because then they only mess things up" (Ibid.: 7). A representative of another party was wary of the proposal to allow antennas to be built without permit up to 5 meters, because it would take away the possibility from municipalities to guard the quality of the living environment (Ibid.: 11). The main representative of the local authorities, the VNG, seemed to have been reluctant at first about the 'below 5 meters' rule. The VNG eventually agreed to it because it also wanted to administratively unburden the municipalities as much as possible and it claimed that citizens would soon get used to sitings (as described by Bröer et al. (2010) on the basis of an interview with the VNG).

The national government drafted the antenna policy as a reaction to societal developments around base station siting, which it viewed as problematic since it hampered the rollout of a mobile telephony network. The government's point of view about the necessity of a swift rollout of the technology is crucial for our understanding of the interplay between citizens and government in mast siting controversies, because it explains the government's view on mast siting controversies. It took the perspective that citizen engagement around mast siting and municipalities' involvement in those actions was not to be tolerated. As a consequence, restraints had to be imposed. This meant that municipalities' demands about controlling the spatial planning aspects of siting were not granted. On the contrary, municipalities were restricted in their policy options. The municipalities' problems were reduced to problems of lack of knowledge on behalf of the municipal officials and citizens. To alleviate this problem, municipal official were 'unburdened' of their administrative tasks by allowing the siting of many base stations without building permits, and the Antennebureau was established.

\section{The antenna policy: calls for better public information}

The antenna policy also announced the establishment of the Antennebureau (Antenna Office), an official information portal focused on education about the technology, national policy and health policy in relation to antennas for citizens, local governments and businesses and an Antenneregister (Antenna Register) where all the antennas in the country could be traced. The need for independent public information and communication on the policy and technology had been debated and asked for in par- 
liament since 2001 (Tweede Kamer, 2001b: 7). The government briefly considered initiating a nation-wide 'Postbus 51' campaign (Ibid.: 17), which was the central information point of the government until 2012, but soon afterwards decided against it:

[I] ast year [2001] it has been researched whether citizens show interest in information about antennas. This research showed that information about base stations was only desired by individuals who are directly confronted with a base station. The Antennebureau does have brochures for citizens about antennas and health. Medio 2003 there will be a European information campaign about base stations and health (Antennebureau, 2002: 16).

Instead, it searched for an "objective information point where municipalities, citizens and operators can get information on all sorts of matters" (Tweede Kamer, 2001b: 15). In November 2001, the Antennebureau was established with a sense of urgency about the need for public information, as voiced by the State Secretary of Transport and Public Works and Water Management in her speech at the opening of the Antennebureau. She sketched the societal incentive for the establishment of the Antennebureau:

[w] ith the growth of communication networks we have to take into account that questions from society about safety and spatial planning will arise. That there will be questions and ambiguities is understandable. Occasionally, messages about health risks appear in the media. People also see how antennas change the view of their city or village (Staatssecretaris van Verkeer en Waterstaat, 2001).

The Antennebureau consisted of 12 employees at the start who were responsible for communication via a website, brochures and a helpdesk. It was intended to inform citizens, government, and businesses, as the head explained: "[t]he Antennebureau is the right place for anyone with questions about the effects of radiation on health, technical interruptions, safety, environment, rules and regulations and technique" (Boerema, 2001). 'Anyone with questions' thus had to find his or her way to the Antennebureau. A number of advertisements about its establishment in daily and weekly magazines throughout 2001-2002 had to help to make the information point visible (Ibid.).

The Antennebureau also actively sought to communicate with professionals and intermediaries. In the first year of its existence, it organised several meetings for municipal officials with the aim of informing municipalities about the changed rules and regulations of the antenna policy (Antennebureau, 2002: 5). The questions that were asked by municipal officials during the meetings were published in a report. It is reported that municipal officials asked about local concerns, i.e. 'why are residents concerned about antennas?'. The Antennebureau answered: 
[t]he concern is often caused by a lack of knowledge of the effects of a base station. The Nationaal Antennebureau is an independent bureau of the government (Agentschap Telecom, [Radiocommunications Agency]) that tries to increase the knowledge about base stations through information, and by so doing tries to take away residents' concern (Ibid.: 16).

The Antennebureau thus called upon municipal officials to refer concerned citizens with their questions and complaints to them. It also offered the opportunity to municipalities to organise an information sessions for citizens during which the Antennebureau would explain the health aspects and rules and regulations of base station siting (see section Trickling down the antenna policy below).

In the same way that the mobile phone operators established MoNet as a response to societal debates and concerns about base station siting, so did the Dutch government initiate the Antennebureau as a central information point for questions about siting. The Antennebureau was established with the rationale that local concerns about mast siting were caused by a lack of knowledge about this technology. It also assumed that informing citizens about the "effects of radiation on health, technical interruptions, safety, environment, rules and regulations and technique" would take away this concern. The emphasis on the presumed 'independent' character of the Antennebureau had to contribute to this effect. The aim of the Antennebureau was to become a central public information point with all the necessary information on the antenna policy, yet this happened all in view of: "streamlining the execution of the national antenna policy (...). The aim is clearly to have enough places for siting base stations, because the only way to reach each other now and in the future is through antennas" (Staatssecretaris van Verkeer en Waterstaat, 2001). The establishment of the Antennebureau was fitted into the government's view of wireless communication technology as the economic boost of the ICT developments that were deemed crucial at the end of the 1990s. This resonated, for example, in the opening speech of the head of the Antennebureau: "it was impossible to imagine life today without mobile communication" (Boerema, 2001).

The establishment of the Antennebureau and its focus on informing citizens and municipal officials about health-related aspects from wireless communication technology is a further step in understanding the dynamics of mast siting controversies, and in particular, why scientific knowledge became such a dominant topic in discussions about mast siting. With the antenna policy and the Antennebureau, the Dutch government moved away from the initial issues that municipalities and citizens raised in previous years: concerns about spatial planning aspects, landscape pollution and the demand to become involved. Municipal officials were taught that citizens' concerns about siting arose from concerns about negative health effects, and that the Antennebureau would take away these concerns once citizens received independent, objective information. The Antennebureau was one of the few policy options munici- 
palities had in dealing with a siting controversy and they thus became dependent on its information (see section Trickling down the antenna policy below). I argue, however, that this information was not catered to the expectations and needs of (engaged) citizens.

\section{The antenna policy: exposure limits and calls for more science}

The government did not only deal with the spatial planning aspects of the technology in the antenna policy, but also addressed the increasing concerns of citizens, attributed to worries about possible health effects from base stations. The government implemented exposure limits for base stations in an indirect way by following the recommendations of the ICNIRP from 1998 (International Commission on Non-lonising Radiation Protection, 1998), the European Commission from 1999 (Aanbeveling van de Raad van Ministers van de Europese Unie van 12 juli 1999) and the advice of the Gezondheidsraad from 2000 (Gezondheidsraad: Commissie elektromagnetische velden, 2000). The Gezondheidsraad was asked to advice the government on whether to take a precautionary approach to the siting of base stations. The Gezondheidsraad advised against it because there was no "reasonable assumption" of a health risk from non-thermal effects. The only scientifically proven effects of heating were thought to be well covered by the existing exposure limits (Ibid.). In 2001, the Gezondheidsraad set up a committee on electromagnetic fields with the aim of releasing annual reports in which it would review the existing research. It was foreseen that the committee would play a signalling role following other Health Council activities in other areas such as new health technologies (ten Velden, 1998). In its first annual report in 2001, the committee concluded that there was no new scientific evidence of harmful effects from RF EMF, but also urged the government to fund more research because of continuing "societal uncertainties" (Gezondheidsraad: Commissie ELF elektromagnetische velden, 2001). Two years earlier, the scientific staff of the Electromagnetic fields committee had declared in a newspaper interview that "research [on EMF] is being performed everywhere. The Netherlands is an exception in that regard" (Van Engelen, February 24, 1999)

These calls for more Dutch scientific research were also echoed in the political debate on the new antenna policy. During a parliamentary discussion in 2001, the president of the Committee of Transport and Public Works and Water Management said:

[w]hat still isn't clear, are the effects on the long term. Does the government want to do research into long term effects? Is the government prepared to take initiatives on the national but also international level? We attach great importance to wide-ranging research (Tweede Kamer, 2001b: 13). 
Some politicians referred to the precautionary principle, in particular the fact that it was still not proven that the technology was safe: "[c]ontinued research into the effects on health is thus called for" (Ibid.: 5). The minister reacted that the precautionary principle was taken into consideration in the antenna policy because the exposure limits already took into account a safety factor - "even of 200" (Ibid.: 9). Yet, a few members of the parliament kept on calling for more research (Ibid.: 12). They proposed a motion that requested the government to take initiatives for independent long-term epidemiological research into radiation from base stations, because there was hardly any research yet (Tweede Kamer, 2001a). In 2002, the government asked the Gezondheidsraad advice on the type of research "that would provide better insights into possible long term effects of RF EMF" (Gezondheidsraad, 2003: 47). Soon afterwards, the government funded the Netherlands Organization for Applied Scientific Research (TNO) to start a research project that directly tried to answer the questions posed in the parliamentary motion. It investigated possible complaints from living close to base stations in an experimental laboratory setting using human test subjects.

The Dutch government's decision to fund scientific research as a response to siting controversies was not an isolated case. Many European countries set exposure limits and invested in research programmes (de Marchi et al., 2009; Kheifets et al., 2010; Salomon and Borraz, 2007; van Dijk et al., 2011; Walls et al., 2005). In contrast with the Netherlands, though, some countries took a precautionary stance, i.e. they adapted lower exposure limits for RF EMF than the ones proposed by the ICNIRP or the EU (see section Regulatory divergence in chapter 2 for a discussion of these divergences). In 1999, the Dutch government had asked the Gezondheidsraad for advice on whether there was any reason, "from a scientific point of view", to apply more stringent exposure limits than the limits proposed by the ICNIRP based on thermal effects (Gezondheidsraad: Commissie elektromagnetische velden, 2000: 45-46). The Gezondheidsraad answered in the negative: the scientific evidence for harmful effects was insufficient to justify such a measure. Yet, in other countries such as the U.K., France and Belgium, scientific advisory councils did call for precautionary measures.

In 2000, the Belgian Hoge Gezondheidsraad (Superior Health Council) advised its government to take bigger safety margins than the ICNIRP ones (leading to an exposure limit of $3 \mathrm{~V} / \mathrm{m}$ at the common frequency of $900 \mathrm{Mhz}$ ) since the "INCIRP-WHO recommendations are not coherent, show lacunas and imply value judgements that are debatable, in the light of, ánd the precautionary principle, ánd sustainable development of technologies" (Hoge Gezondheidsraad: Onderafdeling III/4 Stralingen, 2002: 42). Because of industry protest, the Belgian government finally decided for a compromise and chose exposure limits between the EU recommendation and the Hoge Gezondheidsraad's proposal (Belgische Regering, 2005). The Belgian region of Brussels, however, tried to lower this norm again (Brusselse Hoofdstedelijke Gewest, 2007) and in 2009 an Institutional Court decision allowed it to do so, changing the 
Belgian antenna policy overnight, as the regions (the Walloon and Flemish Regions and the Brussels-Capital Region) were now responsible for setting their own exposure limits (Het Grondwettelijke Hof, 2009). This led to a lacuna in the Flemish law on siting antennas for almost two years: during this time, there were no exposure limits to which mobile phone operators could refer when siting base stations. During this time, groups of citizens won several court cases against mobile phone operators because of this lack of official exposure standards (Interview MA6, MA7 \& MA8). The Hoge Gezondheidsraad reconfirmed its pro-precautionary advice in 2009 (Hoge Gezondheidsraad, 2009). Flanders now follows the norm established by the Belgian federal government in 2005 (Belgische Regering, 2005) with an additional norm of 3V/m on locations where people stay for a longer time (Vlaamse Regering, 2011).

In this section, I discussed the Dutch government's dealing with public concerns about health effects from living close to base stations. Besides more information about health risks from base stations, it addressed these concerns by setting exposure limits for the antennas based on the Gezondheidsraad's advice. Even though there were brief discussions in parliament about establishing lower exposure limits as precautionary measures, the Dutch government followed the advice of the Gezondheidsraad. After such a clear position on the appropriateness of the existing exposure limits, it seems contradictory that the government also invested in more scientific research. This latter policy decision increased the focus on health risks from the technology, as I will discuss in the next chapter. Moreover, it made 'science' into an active actor in the controversy around base station siting: science became a judge that had to rule whether the siting of base stations was considered safe or not (and thus should continue or not). This had a direct influence on mast siting controversies, since the government intended to communicate this scientific knowledge to citizens who were confronted with the siting of a base station through the Antennebureau.

\section{Trickling down the antenna policy}

The antenna policy and the national government's investments in more scientific knowledge and more communication of that knowledge changed the situation for municipalities. They (or at least some of them) had been an important reason for the government to draft the new antenna policy in the first place, and it was thus not surprising that clear guidelines were established that determined how much freedom municipalities had in deciding whether and where antennas would be sited. The antenna policy stated that municipalities were not allowed to refuse the siting of antennas or masts based on health risks if the EMF exposure from the antennas did not exceed the limits recommended by the EU and endorsed by the Dutch government. Municipalities only had to give a building permit for the siting of masts (construction of pylon), and not for the antennas placed below 5 meters. On the other hand, the government urged mobile phone operators to be more open about their siting plans. 
Municipalities had to receive a map with intended sitings from each mobile phone operator every year. One mobile phone operator told me that they try to be open and cooperative towards the municipality for example by explaining the map in person if necessary, discussing how the sitings fit with the local antenna policy (if that existed) and anticipating which masts might become a problem (Interview M9 \& S6).

Yet, the relationship seems to be an unbalanced one, as one alderman for spatial planning phrased it: "providers say 'we have the assignment from the government, we have to site this. We have been given a concession and part of that is to ensure coverage within a certain time. The government is behind us" (Interview E1). So concretely this meant for the municipality that "you cannot simply say to [a provider] 'we refuse to site a mast', because if they go to court they apparently win", according to the alderman for spatial planning in Maastricht (Interview M5). The municipalities experienced that their choice of actions was limited: "if a provider shows that its installation adheres to the exposure limits, then it is fine for us", according to the a municipal official (Interview M7). The national antenna policy thus put municipalities in a twist. They were the first contact point for concerned citizens with questions about mast siting, but could not accommodate citizens' concerns because they were not the authorities in charge concerning base station siting. Sometimes municipalities lined up with engaged citizens to react against the national government's antenna policy, such as in Spijkenisse, even though municipalities had no legal rights to do so. The main means by which municipalities could address siting controversies was through organising an information session. The mobile phone operators would often advise the municipality - especially when the siting might be "sensitive" - to give information in the form of an information evening by the Antennebureau, which the mobile phone operators believed to be an independent institution (Interview M9 \& N9).

The information sessions of the Antennebureau were established from the rationale that only citizens who were confronted with a siting wanted to be informed. The national government considered such an information session as the best way to deal with local concerns. A 2005 evaluation of the antenna policy confirmed this view as it claimed that "direct, interpersonal communication in the form of, for example, information evenings is most suited to the needs of citizens for information, explanation and the feeling of "being heard'" (Tweede Kamer, 2005). The evaluation, however, also stated that "municipalities barely played a role in the communication with residents, whilst the position of municipalities, close to citizens and with knowledge of the local situation, could be used better" (Ibid.). The national government considered municipalities to be crucial actors in translating the national antenna policy to citizens. But how did this work in practice? And how did the information sessions influence the societal dynamics between citizens and the national antenna policy, citizens and the municipality, and citizens and scientific knowledge local dynamics of mast siting controversies? I attended several information sessions during my fieldwork, interviewed representatives of the Antennebureau, and asked for citizens' experiences of these 
meetings during my case study research (see section The research in chapter 1 and appendix 2).

\section{The organisation of information sessions}

Based on my interviews and participant observations, these meetings had the following structure. The Antennebureau presented the technical and policy side of siting antennas: the technicalities of antennas (how they work), the practical use of antennas (why society needs them), the national antenna policy and rules and regulations (under which circumstances siting is permitted), and the role of the Antennebureau (relationship to ministries). In addition, a representative of the mobile phone operator who wanted to site a mast or antenna, presented the reason why the base station had to be sited there. This involved showing the search areas that the radio-technical expert of the mobile phone operator had identified, i.e. areas where the network needed to be thickened or where there would be a gap because antennas had to be taken away. Within the particular area, the mobile phone operator had chosen a 'suitable' location. Another integral part of the information evenings was a presentation about the health aspects of base stations, given either by the local GGD or by the Antennebureau. ${ }^{29}$ Each presentation on health aspects was slightly different ${ }^{30}$, but overall one discussed what electromagnetic fields are, the types of research investigating the possible health risks from RF EMF and the types of effects from exposure to RF EMF such as thermal and non-thermal effects and interference with medical devices. The GGD further detailed the possible non-thermal health effects such as brain activity during sleep and cognitive functioning, and showed the evidence supporting these complaints for each possible effect. In addition, studies that circulate on the websites of grassroots support teams such as StopUMTS were mentioned, and their scientific rigour was questioned. The overall message of the GGD presentations was that the likelihood of health complaints due to exposure to RF EMF was small, but that more research efforts were needed and were on their way.

\section{Communication of risks to an engaged audience}

Information sessions are an important part of the activities of the Antennebureau on the local level, as organising an information session is considered an outstanding way to provide knowledge about wireless communication technology to engaged citizens. Yet, in cases of mast siting controversies, I assert that this assumption is problematic

\footnotetext{
${ }^{29}$ At one information evening, the representative of the Antennebureau did not want to involve the GGD, as this person believed that the Antennebureau had more up-to-date information and was thus better equipped to present.

${ }^{30}$ I observed only one presentation by the GGD during the information session in Echt (GGD Limburg Noord, 2012). However, an online search revealed several presentations with largely the same slides (for example, GGD Hollands Noorden, 2007; GGD Regio Nijmegen, 2012).
} 
for several reasons. Firstly, presenting 'clear scientific facts' to citizens is difficult since scientific facts can be contested (as we have seen in chapter 3) and (engaged) citizens debate the uncertainties within scientific knowledge. Secondly, (engaged) citizens can and do acquire knowledge elsewhere before coming to the information session. Lastly, the audience can consist of not only neighbours but also individuals from grassroots support teams or other professionals who are very critical of the information provided. I will discuss these three issues in more detail in the following sections, as they are crucial for understanding the interplay and the dynamics of siting controversies.

\section{Presenting science}

I will first discuss the issue of the Antennebureau's task of presenting the government's view on scientific knowledge. Citizens attending information meetings turned out to be more interested in the uncertainties in scientific knowledge and the broader idea of what counts as relevant knowledge than in the established scientific facts. As I outlined in the previous chapter, most engaged citizens in my cases were not so much convinced that there were in fact adverse health effects related to masts, but they had serious doubts about it. The presentations of the Antennebureau, however, did not address, let alone openly discuss, these uncertainties. They were set up as opportunities to convey the facts about the antenna policy and health aspects as understood by the government and by its experts. The only way in which the GGD alluded to uncertainties during presentations - without explicitly uttering the word - was when it referred to the need for more research into long-term effects and aspecific complaints (e.g. around electrohypersensitivity) (GGD Regio Nijmegen, 2012). The GGD mentioned that more research and keeping track of developments were also precautionary measures.

The GGD spent a large portion of the presentation on discussing particular studies that did or did not adhere to these standards. For example, a study commonly known as Naila (Eger et al., 2004) that claimed to show an increased risk of cancer when living close to a base station was highlighted as "not adher[ing] to the criteria of good scientific research", according to the GGD Noord-Limburg. The GGD thus implicitly explained the criteria for good scientific research according to the government, and presented them as established facts. The Naila study was conducted by five German physicians who ran a statistical evaluation of medical data of cancer occurrences in a radius of 400 meters from a base station in the city of Naila and found more occurrences of cancer within this area. It quickly became a popular resource for engaged citizens and grassroots support teams. In Nieuwkoop, for example, the study featured in the documents of the lawsuit that some engaged citizens started against the mobile phone operator, as an example of a study showing adverse health effects from RF EMF (N1, 2004). The study was also mentioned in my conversations with engaged citizens there. During one occasion when I walked around the neighbourhood with 
one of them, he pointed out that his house was within 400 meters of the mast, as was the football field. The 400-meter radius thus became an indicator of unsafety for him (Interview N3). Scientific and health institutes reacted to the popularity of the study amongst engaged citizens by questioning its scientific standards, such as the GGD did during information sessions. The Gezondheidsraad disqualified the study in its Electromagnetic Fields: Annual Update 2005 on EMF, even though the commission normally does not review studies that are not peer-reviewed (Gezondheidsraad, 2005: 87-89).

The GGD put a lot of effort into explaining why certain studies were not taken into account in the government's antenna policy because their scientific quality was deemed inadequate. Yet, as I will explain in detail in the next chapter, these scientific criteria can be contested, and also were contested by citizens during the information session in Echt. Citizens in the audience questioned the scientific studies presented, and were interested in how uncertainties were taken into account. One citizen commented on the "vague results" of the presented studies: "you say Wi-Fi - there is no effect on children, but how can you say that already, you cannot research this in just one year?" The representative of the GGD reacted by saying that scientists have only found an effect from heating (thermal effect) and that so far none of the studies gives a clear image of possible effects. The citizen replied: "so you draw conclusions on the basis of something uncertain?". Another citizen in the room also referred to the last slide in which it was suggested that more research was needed for children: "let's accept that there are uncertainties and let's take the precautionary principle into account". The representative of the GGD replied "as a clarification: there are large safety margins taken into account" and referred again to the precautionary measure of more research.

Communicating the scientific knowledge to citizens was not as straightforward as the Dutch government assumed: it came down to communicating the scientific knowledge that the national government deemed relevant. Any presentation thus involved explaining the government's criteria to which scientific studies had to abide in order to become considered as proof of harmfulness or safety. Citizens were presumed to rely on the information on scientific studies, and on the best siting locations, provided by the mobile phone operator, and endorsed by the government. In this 'information provision' context, there was however no room for uncertainties to be discussed (compare Grove-White et al., 2000). The scientific studies were "cast as inputs to choice, their uncertainties or limitations [become] matters for individual judgment - and not grounds on which expert claims could be criticized" (compare Ottinger, 2013b: 54). Indeed, the goal of the information sessions was to "give objective information so that [people] can make their own choice", according to the representative of the Antennebureau (Interview N9). This "objective information", however, was contested by the audience and other studies, disqualified by the government and its experts' bodies, were brought to the fore (see chapter 5 ). 


\section{Citizens' information needs}

Another reason why information sessions did not have a soothing effect on siting controversies, as the government assumed, was the discrepancy between the primary aim of information sessions, i.e. communicating information, and the actual information needs of citizens. Engaged citizens often already gained knowledge elsewhere, through their different landscapes of knowledge (see chapter 3). Part of this information came from government sources, but a large chunk originated from grassroots support teams that were very critical of many of the studies on which the government relied. Moreover, through personal networks, citizens encountered stories of people experiencing illnesses that they attributed to exposure to base stations or other EMF sources. It often occurred during meetings that people stood up and told their own personal experiences with the technology, usually about illnesses they or others have developed. "Stories of experience are very common during meetings; they are very emotional and tragic and are often received with applause", according to a staff member of the Antennebureau (Interview N9). This seems to have happened during an information session in Maastricht: "if you are convinced that such a mast has an effect on your health then you speak up", according to the municipal official in Maastricht who had been present at the meeting (Interview M8). She immediately added that "this of course brings forth a lot of emotion". The problem in her view was the ensuing dynamic with the official presenters in the meetings, those that "tried to refute this objectively": "that is very difficult, because the emotion is sometimes so deep that you cannot convince this person that it is incorrect what he thinks. That it is not scientifically proven what he says".

The whole idea of the information evenings of "giv[ing] objective information so that [people] can make their own choice", as a staff member of the Antennebureau put it (Interview N9), was at odds with the needs of engaged citizens, present at these evenings. There was a mismatch between citizens' and organisers' views of the information session: citizens wanted to discuss the situation of the upcoming siting, but the official speakers there could only convey information meant to convince individual citizens. The sessions were not designed as opportunities for public discussion, as classical town hall meetings or informal public meetings. Yet, by the time an information session was organised, citizens often already started a collective engagement against the siting. In Valkenswaard, for example, the municipality did not want any questions to be asked during the session and had provided pen and paper for questions to be written down and answered at the very end of the meeting. Citizens were not happy about this, especially when at the end of the meeting, there was not enough time and the municipal representative said they would answer the questions in written form later, much to the annoyance of the people present.

From my participant observations and interviews, I conclude that people going to such meetings mainly consisted of engaged citizens, who were part of a collective, and 
who were well informed already. A representative of a mobile phone operator claimed that those that agree with the siting do not come, and those that like to get more information are usually silent during the meetings (Interview M9). A staff member of the Antennebureau explained that she gives the information session for those who are still in doubt in order "to prevent that they are heavily influenced by the group of fierce opponents". And even if those 'doubters' are happy with the information received, "those are not the ones you hear, only the fierce group" (Interview N9). According to these actors, the information provision should mainly be catered to those individuals that have not yet formed a strong opinion, before they can be influenced by any of their neighbours. However, my analysis of mast siting controversies and information sessions shows that information sessions should 1) not just be about one-way communication, but about listening to citizens and involving them in the siting decision and 2) should primarily be catered to engaged citizens, because they are the ones who are most involved with the mast siting and who are in need of discussion.

\section{A mixed audience}

I observed that at such information evenings, also members of grassroots support teams or individuals with a clear interest in proclaiming health risks from base stations were present. They did not have a stake in this particular mast siting, but sought influence in all base station sitings, hence in the national policy. Information sessions were not only attended by residents of the neighbourhood where the mast was going to be sited but also by those who saw it as their task to warn people against possible dangers of RF EMF. In two of the meetings I observed, a man had been present who caught everyone's attention, much to the dismay of the organiser. He made his presence known as soon as he entered the building, because he wore a hat with a cloth draped over it that supposedly protected him from EMF, as I learned later. He also had several measuring devices with him that zoomed and beeped throughout the entire meeting. He identified himself as the initiator of the Flemish grassroots support team StralingsArmVlaanderen: he was electrohypersensitive and went to any information session organised within 100 kilometres from his home. He disrupted the presenters regularly with very specific and technical questions, sighed, and moaned regularly, presumably whenever something was said that he did not agree with. During one information session, he was joined by someone who identified himself as a building biologist (Baubiolog in German), meaning that he measured EMF in homes and took into account exposure limits that were "much lower" than the ones presented during the information session. He claimed that people slept better and felt better after he had reduced the exposure to EMF in the house. Also, in Spijkenisse, a man had attended the information session with a fake bird in a little cage, all the while 
proclaiming that they had these birds in the mines to warn them for gasses but that now there was no bird to warn anyone against too much radiation (Interview S7).

The presence of individuals that did not live in the neighbourhood further amplified the discrepancy between the Antennebureau's aim of providing information to those citizens who supposedly lacked it, and the reality of engaged citizens who already acquired knowledge and formed an opinion about the siting and who wanted to discuss the siting decision, or at least the specific location. Actually, through these information sessions, the local citizens personally met individuals who advanced the view that exposure to base stations makes you ill, which was at odds with the government's view.

\section{Information sessions as crucial dynamic in siting controversy}

In all of the Dutch mast siting controversies I studied, the municipality organised an information session with the Antennebureau. These meetings, however, often did not have the intended effect of appeasing the mast siting controversy. In Spijkenisse, the room in which the meeting was held was much too small for the number of people showing up. The engaged citizens had distributed flyers in the neighbourhood and had instructed people to attend the meeting en masse. The then alderman of spatial planning who organised the meeting still remembered it well after several years:

[t]there were so many people from the direct neighbourhood and there was such a tense atmosphere. Especially the opponents who made it very clear that they did not want it. And that meant that no matter which arguments were used, people did not or hardly listened (Interview S3).

Also in Maastricht and Nieuwkoop, the meetings became quite heated. In Maastricht, there was "a lot of hustle and bustle. A lot of questions, more than there was time for" (Interview M2). In Nieuwkoop, people became "so upset that they ran outside, slammed the door behind them and walked away in anger" (Interview N3). The citizens there referred to the meeting as a "good news show" (Interview N1) or "meeting of reassurance" (Interview N5) and claimed that even more neighbours became concerned after the meeting because it was purposely set up to reassure them instead of getting them involved and listening to their concerns. When the municipality organised a second meeting in Nieuwkoop a few weeks into the mast siting controversy, the engaged citizens refused to attend, which angered the alderman of spatial planning. The engaged citizens reasoned that it did not make sense to go again, since they already made their arguments clear in their notices of objection and in conversations with the municipality. The line of approach of the information session was to explain, again, that radiation is not dangerous and that it was really the best place to site the mast, all points with which they disagreed, according to one engaged citizen (Interview N3). 
I summarise the societal dynamics around information sessions as follows: 1) the audience was a critical and knowledgeable set of citizens and interested parties. They were interested in discussing the siting and expected to be heard. As it concerns information, they were not unaware of the science, but they were mostly interested in questioning the scientific knowledge by referring to uncertainties. Secondly, 2) the expectations citizens had about these meetings, especially if they already started to engage around the siting, did not fit with the official aim of the meetings, which was to convey (scientific) knowledge. The information sessions usually took place some weeks after the announcement of a siting, and often only after there had been some societal unrest (such as a lot of questions to the municipality, media attention or collectives of engaged citizens being formed), but yet the whole idea of the meetings was one of informing individual citizens who lacked information, in the form of top-down communication. Citizens, on the other hand, 3) saw the information sessions as an opportunity to voice their concerns, critique and questions. The information meetings did thus not strike with the expectations of citizens: many had the idea that there would be room for an open discussion, for example about the location of the to-besited mast.

As I discussed in chapter 3, citizens were not against the siting of all masts in the entire country, but demanded a thorough decision from the municipality on where to site this particular mast. The Dutch government, however, assumed that citizen engagement arose from a general fear of radiation, and thus citizens were cast as being against all masts anywhere. The government seemed to have reacted to the rhetoric of grassroots support teams, who were very avid in opposing all masts (see chapter 3 ). Citizens' arguments about the siting in local controversies were different: they never opposed the development of the entire technology, but were mainly concerned about the mismanagement of the local siting process and the quality of the decision-making process. Also in the information sessions, it became clear that citizens wanted to discuss the location of the mast, yet instead there was a one-way communication of generic information about health risks and national policy.

There are some positive examples from mast sitings that underline the importance of involving local residents in the decision on where to site the mast. In one of the information sessions I attended, in Euverem, there was room to discuss the location of the siting. This seemed to be the upshot of some coincidences. The mobile phone operator was present and agreed to opening up the discussion of the location. When the session was organised, the mast was planned to be sited in the village centre, close to a car park and a children's playground. Most citizens did not agree with this location. During the session, the mobile phone operator explained the alternative locations that the technical expert had identified, of which some were located in the fields surrounding the village. Citizens were in favour of one of these alternative locations. It had not previously been considered because it did not fit in the municipality's zoning plan. The council member of spatial planning agreed that the municipality 
could and would change the zoning plan after the majority of citizens present at the information session consented to this location. The mobile phone operator told me that they valued such an unanimous decision and even tried to incorporate local knowledge of citizens in some siting decisions (Interview M8). They gave an example of an information evening where they discussed four possible locations with the neighbours. The citizens came up with a fifth location, which the mobile phone operator had excluded because the owner did not cooperate. Neighbours informed them that there were new owners, who eventually agreed to the siting of an antenna on their roof.

I conclude that information sessions are vital in understanding the dynamics in mast siting controversies, because they show the tensions and discrepancies between different government levels: the national government that came up with the national antenna policy, and local government (municipalities) that have to act as spokespersons of this national policy. The national government decided in its national antenna policy that citizens were disqualified to engage, but should be informed about the policy, a responsibility that came down to municipalities with the help of the Antennebureau. During such information evenings, generic information is conveyed about scientific studies into health risks from RF EMF, the national antenna policy and the mobile phone operator's approach in finding a location. Yet, I argued that citizen engagement arose because of concerns about the local situation (chapter 3 ). Citizens that are present in these sessions are interested in their local situation and ask questions such as 'why does the mast need to be sited at that particular location?' Citizens assess the siting decision as a decision of their local government, with whom they have previous experiences and for whom they hold specific expectations. Hence, there is a mismatch between the national policy assumption about citizens and their concerns and related solutions to mast siting controversies and the local engagement of citizens.

\section{Conclusion}

In this chapter, I went through different arenas to show the range of discussions about mast siting, rules and regulations of the antenna policy, and implications of this policy.

The national government antenna policy was a re-action to societal developments around base station siting: citizens and/or municipalities started to engage around the siting of base stations. Some municipalities developed their own antenna policy that imposed restrictions on the perceived uncontrolled proliferation of base stations. The national government and the mobile phone operators viewed these developments as problematic since it hampered the rollout of a mobile telephony network. The government's antenna policy established safety margins based on the Gezondheidsraad advice. According to the government, the existing scientific 
knowledge about health risks from RF EMF gave a reassuring picture, yet the government also deemed it necessary to fund more research to keep on monitoring the situation. On the other hand, the antenna policy also ensured that neither citizens nor municipalities could disrupt the siting of base stations on the basis of possible health risks. The municipalities' problems were reduced to problems of lack of knowledge on behalf of the municipal officials and citizens. To alleviate this problem, municipal official were 'unburdened' of their administrative tasks by allowing the siting of many base stations without building permits. The government also established the Antennebureau as a central information point about the antenna policy. In different ways, the national government's policy diminished the municipalities' authority in deciding about base station siting.

The struggle between different levels of government, i.e. the national government and municipalities, about the legitimacy of mast and antenna siting led to a restriction of the policy options for municipalities and reduced them to spokespersons for the national antenna policy. The antenna policy put the municipalities in a split: they had to follow strict rules and regulations on base station siting yet could not ignore the dissatisfaction and concerns expressed by their citizens. One task of the Antennebureau was to help municipalities in dealing with local concerns by giving direct information about antennas in the form of presentations. Yet, as my previous analysis of citizen engagement showed (chapter 3), citizens wanted to become involved in the decision-making process and wanted their concerns to be taken seriously. The information sessions were set up from the premise that citizens lacked knowledge, or had been misinformed, about the health aspects from masts. They were not intended as deliberations, but as one-way information flows. Citizens attending these meetings had different expectations of the purpose of these gatherings: they wanted to discuss the siting, explore alternative locations, questioned scientific assurances and wanted to discuss uncertainty and precaution. The topic of health risks was thus not something that the municipalities ought to discuss, but rather ought to communicate, as it was a matter that was dealt with by the national government and by its advisory bodies and (inter)national scientists (see next chapter). At the same time, the arrangement in place made any reference to health risks on a local level a dead alley, which was contrary to what citizens expected (compare chapter 3 ), which further increased the tensions.

I conclude this chapter by summarising what the analysis of the political decisionmaking process means in terms of understanding the dynamics of the wireless communication technology controversy. Firstly, the prioritisation of the national level of regulation in the antenna policy led to the denial of the legitimacy of local government levels in siting decisions. Over time, municipalities only got a bureaucratic, executive role without much room for local involvement in the siting decision. The national government decided that municipalities 1 ) had to consent to the siting of most of the base stations and 2) were not (much) involved in where the base stations would be 
sited. These decisions were in the hands of the mobile phone operators. The national government thus enforced a national policy that ignored the local concerns that the initial rollout of the technology had raised. Secondly, the Dutch government's policy response of risk communication to concerned citizens reinforced the assumption that citizens' concerns about siting were solely related to health risks. This not only meant that the Dutch government ignored all the other issues that municipalities and citizens raised, such as concerns about spatial planning aspects, landscape pollution and the demand to become involved, but also led to a particular governance strategy of investing in risk research and risk communication, which I will discuss in detail in the next chapter. 
CHAPTER 5

The role of science in the antenna policy 


\section{Introduction}

The Dutch government's strategy in dealing with siting controversies consisted of investing in risk research and risk communication. This 'risk-based' policy approach tackled two presumed deficits: a deficit of scientific knowledge and a deficit of communication of that knowledge. In 2005, the Minister of Economic Affairs ${ }^{31}$ explained: we "think that every large-scale introduction of new technologies, such as UMTS, should coincide with precise communication and information and with the execution of research into possible and unintended side effects of these new technologies" (Tweede Kamer, 2005). If science could proof that siting base stations was without risk, the logic went, and if society could understand the science behind EMF health effects, there could be no legitimate opposition to siting anymore. To these ends, the government turned to science. It asked its science advisors for advice and funded scientific research into possible negative health effects of the technology. In 2002, The Netherlands Organisation for Applied Scientific Research (TNO) received funding to investigate health risks from living in close vicinity to base stations, with a particular focus on UMTS-technology. Two years later, the government partly funded another Swiss research into UMTS-technology. In 2006, again, it invested 16.6 million euro in a research programme on EMF and health. Scientific knowledge about possible health risks from exposure to RF EMF also became the basis of the government's communication plan. Since 2001, the Antennebureau ensured the communication of the national antenna policy to professionals, municipalities and other interested parties (see chapter 4). In the following years, the government also invested in a network of expertise on EMF and Health that concentrated on risk research and risk communication, the Kennisplatform EMV \& Gezondheid (Kennisplatform EMV\&G; Knowledge Platform EMF \& Health). This network also set up the Klankbordgroep (Sounding Board), i.e. a deliberation exercise with diverse societal actors, such as grassroots support teams and interest groups, to discuss the topic of EMF and health.

In this chapter, I discuss how the Dutch government relied on and used the image of science as arbiter in dealing with mast siting controversies. Because the siting of base stations invoked questions about safety margins and possible health effects, the government turned to scientists for more insights into the health aspects related to this technology. Yet, as I have argued in the previous chapters, the siting of base station was also a societal problem that had a close connection to issues of spatial planning regulation, participatory governance and rights of protection. Still, it was scientific knowledge that became centre stage in the years following the first siting controversies. In the previous chapter, I argued that the decision-making process around mast siting controversies in the Netherlands illuminated the "deeply problematic habit

\footnotetext{
${ }^{31}$ See section From technology push to national antenna policy in chapter 4 for an overview of the ministries responsible for the antenna policy.
} 
of describing public issues involving scientific questions as 'scientific issues'" (Wynne, 2006: 124; my emphasis). The government framed mast siting controversies as a problem of health risks and thus as a 'risk issue', and hence as a scientific issue. Once the activity of mast siting had been identified and accepted as a 'risk', a 'risk-based' policy approach could be applied, i.e. a "set of standards, protocols and guidelines that define how risk objects should be assessed, evaluated, managed, communicated and monitored" (Borraz, 2011: 970). The goal of a risk-based policy approach is to turn societal concerns into 'risks' that can be scrutinised by scientists, who are believed to have the authority and capacity to characterise, assess and reduce uncertainties. The Dutch government expected that the "broad array of measures and activities in the area of information, communication and research" would improve the societal acceptance of mast siting (Tweede Kamer, 2005). However, during the period in which the government invested in scientific research and communication, the number of mast siting controversies rose significantly. I argue that using science as arbiter in the political and social discussion about base station siting shifted the public debate from dissatisfaction about spatial planning regulation to a focus on health risks. It polarised the positions in the controversy and over time science went from judge to becoming judged itself.

I will first discuss the social science literature on science for policy: the type of scientific practice that is closely connected to policymaking. What do we know about the role of science in politics and policy? I use these insights to explain the decisionmaking process around mobile phone mast siting in the Netherland between 2002 and 2006, when the government funded research into health risks from RF EMF to tackle the presumed deficit of scientific knowledge. Next, I describe the critical reactions from societal actors on the government's portrayal of 'regulatory science' (Jasanoff, 1990). Science became an important resource, not just for policy makers but also for engaged citizens, grassroots support groups and other interested parties. Science went from judge of a policy decision (should we continue with the siting of mobile phone masts?) to being judged itself by public actors (is this the right knowledge on which to base decisions?). Instead of appeasing the controversy, the focus on health risk entrenched the public discussion and polarised the different views about mast siting. Notwithstanding the social and political discussion that the resort to regulatory science had generated, the government continued its communication plan of providing 'clear' scientific knowledge to society through intermediaries. In chapter 4, I discussed the communication activities of the Antennebureau. In this chapter, I focus on another arrangement, the Kennisplatform EMV\&G, which can also be considered as an attempt at deliberation. 


\section{Science for policy}

The dual steps that the Dutch government undertook in order to solve siting controversies - risk research and risk communication - could be witnessed in many European countries at the time (see section Early engagement in chapter 2). Science for policy has become common practice today in politics:

We live in a political culture that is steeped in science. When faced with dilemmas over food safety or phone masts, climate change or child vaccination, the first response of politicians and regulators is to seek refuge in 'sound science' and the advisors who produce it (Wilsdon and Willis, 2004: 13).

The calls for 'evidence-based policy' can be explained by the "the degree to which the problems that society faces have some close connection to the issues of science and technology, for example in the areas such as disease, development, terrorism, environmental impacts, adoption of new technologies, and so on" (Pielke, 2007: 31). Moreover, there is an assumption that science is a powerful ally because it is believed to provide solid proof - a vision of how science and politics could work together that is deeply engrained in our modern society. The idea that science should provide conclusive evidence that society needs - or in other words, the idea that policy should be based on objective, reliable knowledge - has a long history in Western thinking, going back at least to Plato's Republic (Millstone, 2007).

This classical or conventional account of science-based policy-making is known as 'the technocratic model' or 'linear model' (Millstone et al., 2004; Pielke, 2007). In this view, scientific consideration and expert advice are seen as the only solid basis for policy-making. Science is understood as a 'factual policy informant'. In this model, policymakers deploy science as a source of public and political authority, or as Brian Wynne (Welsh and Wynne, 2013; Wynne, 2010) has phrased it, as 'scientism'. Scientism is the engrained assumption that scientific evidence is the only authority that can justify policy action. If science is used to appease controversial political decisions, politicians and policymakers rely heavily on the image of science as research and specialist knowledge-production. In this view, science is primarily concerned with producing 'certified knowledge', a term coined by the godfather of American sociology of science Robert Merton, and signifies knowledge that is not tainted by economics, politics, religion or ideology, but that is only strictly scientifically certified (Merton, 1973). Science is thus portrayed as a tidy set of knowledge ready to be fed into policy. The only thing politicians have to do is commission research, await its results and base their policies on the outcomes of scientific research. It has often been encapsulated in the claim that policy should be based on, and only on, 'sound science': "[i]n this 'technocratic model' the politician becomes fully dependent on the expert. Politics is replaced by a scientifically rationalized administration" (Weingart, 1999, p. 154). It has been a specific guidance for the role of science in the context of decision making since 
after World War II (Pielke, 2007; Weingart, 1999). It is still very much alive today under the new umbrella of 'evidence-based policy' (Slob and Staman, 2012).

In the technocratic model, the role of science is well-defined as one of providing objective, reliable knowledge. This view of science has been criticised by scholars from science and technology studies (STS) and policy sciences who have investigated the actual role of science and expertise in policy and decision making (see for example, Funtowicz and Ravetz, 1990; Harremoës et al., 2001; Hilgartner, 2000; Jasanoff and Wynne, 1998; Jasanoff, 1990, 2005; Klinke and Renn, 2002; Millstone et al., 2008; Nelkin, 1979; van Asselt et al., 2013; van Asselt, 2005). This type of research is concerned with the relationship between science and policy processes, taking into account the intermediary layer of expertise, or 'regulatory science' (Jasanoff, 1990). Several decades of scholarship has unravelled a number of dynamics in the making of science, and in particular science for policy, each of which I will discuss in more detail in the next sections. Firstly, that science is socially constructed, i.e. the outcome of value judgments and boundary work. Secondly, that science often does not end controversy that involves political, technical and scientific questions, but may in fact reinforce it. Thirdly, that public disagreement with the judgment of science advisers is not the result of a lack of knowledge on the part of citizens (intellectual deficit), but rather the outcome of the public's ability to disagree with underlying normative assumptions in scientific advice. These findings challenge the conventional technocratic assumptions about the nature of scientific knowledge and the role of experts.

\section{STS insight: science is socially constructed}

The linear model assumes that the boundaries between science and policy are well defined and ring-fenced: science produces facts that guarantee the best policy decisions. Social science research, however, has shown that (regulatory) science is not independent from the social and political context in which it is embedded. Instead, the boundaries between science and policy or politics are constantly being renegotiated as part of a political process (Jasanoff, 1990). The social context can thus not be separated from the scientific context, but is an integral part of it. The concept of 'coproduction' is used to refer to the understanding that scientific knowledge is not independent of political context, but is co-produced by scientists and the society within which they are embedded (Jasanoff, 1996, 2004). The outcomes of scientific processes are invariably framed by value judgments such as which scientific disciplines and knowledge is relevant, what to do with dissenting viewpoints, what should count as relevant evidence and how to interpret scientific results. Analyses by social scientists (see e.g. Jasanoff and Wynne, 1998) have provided detailed evidence that indicates that "a range of prior social, cultural, institutional, and practical commitments are embedded and reproduced, usually tacitly, within technical risk assessments that typically purport to be objective" (van Zwanenberg \& Millstone, 2000, p. 259). 
Millstone and colleagues (2008), for instance, explain how scientists make upstream framing assumptions when deciding on, performing and evaluating scientific evidence for policy ends. Scientists make crucial assumptions in their work related to what kinds of objects and phenomena they are interested in, which are relevant and which should be ignored or discounted (prior ontological assumptions). Scientists make different sorts of assumptions: a) epistemological assumptions about what there is to be known, and what counts as relevant forms of knowledge and evidence; b) methodological assumptions about what are appropriate means for generating knowledge claims, and how those claims can be supported and/or challenged; and c) normative and interpretative assumptions about how the outcome of their deliberations should be reported and represented. Scientists thus disagree over what counts as relevant forms of knowledge and evidence. These disagreements become problematic when science is used to solve a political controversy. Values that are embedded in scientific knowledge for regulatory policy are then exposed to public scrutiny. The framing assumptions are part and parcel of the scientific enterprise, but crucially, determine the ways in which science for policy is framed, conducted and reported. For example, different scientists may weigh scientific uncertainties differently, as becomes apparent from different conclusions from advisory panels or expert deliberations, also on EMF and health risks (see Schütz and Wiedemann, 2005; van Dijk et al., 2011; see chapter 2, section Regulatory divergence).

Thus, a view of science as an apolitical, objective and reliable factual policy informant is problematic, since it does not strike with how science for policy actually works:

[t] he idea that science could even provide proof is a misunderstanding (or misrepresentation) of science and therefore of the role that science ever could play in policy. In all but the most trivial cases, science does not produce logically indisputable proofs about the natural world. At best it produces a robust consensus based on a process of inquiry that allows for continued scrutiny, re-examination, and revision (Oreskes, 2004: 369-370).

The insights about the socially constructed nature of science severally complicate the traditional image of science as factual policy informant, left to its own devices far away from politics. Consequently, scholars have asked how we can explain the continued authoritative role of science in policymaking, even though science is socially constructed. How can science be socially shaped and yet still be used as a technocratic instrument to end social and political controversies? Social scientists have explained this 'paradox of scientific authority' (Bijker et al., 2009) with the concept of boundary work, which relates to the social construction and demarcation of what science is and what it is not.

Scholars have particularly been interested in how scientific advisory bodies, charged with providing governments with scientific advice on matters of public health, 
draw boundaries to present their advice as sound science. Research has been done on the Gezondheidsraad in the Netherlands (Bijker et al., 2009), the U.S. National Academy of Sciences (Hilgartner, 2000) and several American advisory bodies in the area of regulation of chemicals (Jasanoff, 1990). The research shows that advisory bodies draw boundaries between science and politics, between science and non-science, between the advisory body itself and science, between scientific disciplines, and so on (Bijker et al., 2009; Hilgartner, 2000; Jasanoff, 1990). Boundary work is performed at each step of preparing a scientific advice or report: the social organisation and the constitution of committee members or panels of experts (which expertise is needed?), reviewing literature (which knowledge is relevant?), developing recommendations (oriented at science, politicians, practitioners, etc.?) and landing the report (what is the advisory body's aim?). According to Bijker and colleagues, advisory bodies produce 'serviceable truths' (Jasanoff, 1990), i.e. "truthful scientific knowledge that is deliberately aimed at serving certain, often policy, goals" (Bijker et al., 2009: 142). The work of science advisory institutes is thus both scientific and policy-oriented, it is "a hybrid activity that combines elements of scientific evidence and reasoning with large doses of social and political judgment" (Jasanoff, 1990: 229). In their work, science advisors thus construct and maintain their credibility through boundary work.

\section{STS insight: science polarises viewpoints in controversies}

The second insight from STS that helps to understand the role of science in controversies is the finding that using science for policy often has a polarising effect on controversies.

In the early days of science and technology studies, 'controversy studies' emerged out of an interest in exploring science as a human product, as something that has to be made by people. Scholars started to look at controversies both in the present (Collins and Pinch, 1982; Collins, 1985; Pickering, 1984) and in the past (Shapin and Schaffer, 1985). Controversies were productive sites to observe science, they argued, since no facts had been established yet. It was analogous to observing how ships are put in bottles: "[i]nstitutionalised beliefs about the natural world are like the ship in the bottle, whereas instances of scientific controversy offer us the opportunity to see that the ship was once a pile of sticks and strings, and that it was once outside the bottle" (Shapin and Schaffer, 1985: 7). Soon controversy studies extended their scope from disputes over knowledge that were largely restricted within the scientific community to disputes that took place outside the confines of the laboratory or field site' (for an overview, see Martin and Richards, 1995; Sismondo, 2012, chapter 11). These studies no longer solely focused on key scientists that are involved in a scientific controversy, but on a much larger number of actors such as government bodies, experts, citizen organisations, social movement groups and indus- 
try. Scholars wondered why science was often unable to end disagreements around issues of health, safety, and environment.

Dorothy Nelkin's $(1987,1979)$ pioneering work on the role of science and technology in social and political disputes showed that controversies over science and technology are not per se disputes about the everyday implications of - say a waste siting repository - but are more often disputes about political control and the capacity of citizens to influence their power. Controversies over science and technology thus "reflect broader tensions in society" such as "the disagreement over the appropriate role of government, [or] the struggle between individual autonomy and community goals" (Nelkin, 1979: xi). Nelkin observed that a better understanding of the scientific facts often does not put an end to the controversy, but might in fact reinforce value disputes and competing interests. If conflicting scientific views come together in a decision making process, then the 'truth' does not automatically pop up after a long scientific deliberative process. Rather, each side tends to elaborate more and more, leading to polarisation and entrenchment of their positions instead of a move to the middle ground. This polarisation is caused, according to Nelkin, by the values that are inherent in questions portrayed as being purely scientific such as "what is an acceptable level of risk? Who should assume responsibility for evaluating science projects when they may have an impact on public health?" (Nelkin, 1987, p. 285).

Several decades of STS and science policy research has corrobarated Nelkin's findings by showing that, in policy areas for which scientific knowledge is deemed indispensable, "the growth of considerable bodies of scientific knowledge, created especially to resolve political dispute and enable effective decision making, has often been accompanied instead by growing political controversy and gridlock" (Sarewitz, 2004 , p. 386). Scholars claim that the uncertain nature of science for policy enhances the controversy:

the competition for the latest, and therefore supposedly most compelling, scientific knowledge drives the recruitment of expertise far beyond the realm of consensual knowledge right up to the research frontier where knowledge claims are uncertain, contested, and open to challenge (Weingart, 1999: 158).

Because regulatory science mostly investigates issues that are at "the realm of yet uncertain knowledge", more scientific knowledge can in fact amplify the scientific and public discussion (Weingart, 1999: 160). Many scholars have observed that technical or scientific expertise becomes a crucial resource in controversies, not only used by policy makers but also by public actors such as engaged citizens, NGOs or other interest groups (Hannigan, 1995; Leach \& Scoones, 2007; Murphy, 2006; Nelkin, 1979; Tesh, 2000).

STS researchers have indicated that, contrary to the usual scientific myth, discussions of contradicting scientific evidence do not always produce serviceable truths. Instead, when the results of the scientific inquiry have political or economic conse- 
quences, differences in knowledge are likely to be amplified by scientists, but also by public actors (Oreskes, 2004).

\section{STS insight: the public understands science}

Social scientists interested in science for policy have also analysed the public's role in controversies involving scientific issues. The technocratic vision that these scholars criticise portrays citizens as passive recipients of scientific knowledge, who mostly misunderstand what scientists say. Public refusal to accept the opinion of science advisors thus comes down to the public's failure to understand the meaning of science, i.e. it reflects an intellectual deficit. This 'deficit model' of public understanding of science has long been discredited (see Irwin and Wynne, 1996). Moreover, the technocratic perspective views the public as a homogenous entity who reason and act alike. The field of Public Understanding of Science (PUS) has investigated the role of many heterogeneous publics in scientific and technological issues, with diverse values that can change depending on the context. It has come to several conclusions. Firstly, it indicates that the way publics make sense of science is not only through scrutinising the formal contents of science (what is said), but also through evaluating the institutions and scientists presenting this knowledge (who says it), as I already discussed in chapter 3 and 4. Secondly, Brian Wynne's well-known case study of the Cumbrian sheep farmers set the ground work for a plethora of studies that showed that members of the interested public often have expertise that relates to the problem or issue at hand, which may conflict with the experts' opinion (see section Grassroots support teams in chapter 3). Thirdly, members of the public can disagree with the normative assumptions or assumptions about the social world that are inherent in the production of scientific knowledge, but which are unacknowledged by scientists or policy makers.

According to Wynne, there are three elements of the public understanding of science: "the formal contents of scientific knowledge; the methods and processes of science; and its forms of institutional embedding, patronage, organization, and control" (Wynne, 1992: 37). When publics do not agree with the policies that depend on particular scientific knowledge, they may criticise all three aspects of science. They thus not only doubt the scientific knowledge (the formal contents of scientific knowledge), but can also analyse the ways in which the knowledge is produced (methods and processes of science), and scrutinise the institutions, organisations and political actors whose legitimacy depends on the accuracy of this knowledge (forms of institutional embedding, patronage, organisation and control). Publics can thus attribute a range of social meanings to science that may overlap and conflict. They may belief in the abilities of science to solve modern-day problems. In environmental and other public controversies, for example, the notion that science is a source of fact and theories about reality that can and should settle disputes and guide political actions 
remains a strongly held belief, also by publics (Frickel et al., 2010; Sarewitz, 2004; Murphy, 2006; Tesh and Williams, 1996). Different public social constructions of 'science' can thus easily overlap:

[p]eople are not solely disenchanted or disinherited in the face of science; rather, they discursively man[o]euvre around science in a variety of trajectories that can, on one hand, sustain the mystique and the status of science and, on the other, undermine them (Michael, 1992: 330)

Consequently, if citizens disagree with scientific findings, it is not because they do not understand science as a research culture. Rather, it has to do with the "historical process [that] has placed ever-increasing demands on public credulity and trust in institutions, practices, commitments, reassurances, promises and predicted impacts, all justified in the generic name of 'science'" (Wynne, 2006: 212). Citizens do not only judge the contents of scientific results, but also take into account the context in which the knowledge was gained (e.g. ties with industry) and the purposes of this knowledge (e.g. if it serves the goals of a particular ministry). Citizens are interested in questions that are about science, but that cannot be solved by science alone. Examples of these questions are: 'Who has the legitimacy to decide on an important issue that may impact public health?', 'Who will take responsibility for possible effects in the future?', 'Who will be in charge, and can we trust them?' or 'What is an acceptable level of risk that society should take?' (Grove-White et al., 2000; Leach, 2005). The public understanding of science is thus much more embedded in their experiences of life and is "a logical entailment of the gap between public understanding of recurrently present ignorance and uncertainty, and the exclusive focus on positive knowledge within the official information culture of transparency and openness" (Grove-White et al., 2000: 29).

STS scholars in PUS have thus convincingly argued that publics understand science in different ways, but also that they acquire and challenge knowledge.

\section{The presumed deficit of scientific knowledge}

I will come back to these three insights from STS and policy sciences about the social construction of science, the polarising effect of using science as scientism and the public understanding of science, to explain the Dutch controversy that arose over mast siting. I will first discuss the policy decision to deal with the presumed deficit of scientific knowledge, which I argue comes down to using science as scientism or presumed public authority knowledge.

In the 2000s, the government focused predominantly on possible health effects in dealing with local dissatisfaction about base station siting. It asserted that public discussions were increasingly about health risks instead of other issues such as spatial planning: 
[i]n the practice of antenna siting, it turns out that the societal discussion is nowadays less about local planning aspects than it used to be, and increasingly about (fear of) risks for health damage. There has been a slight shift of focus (Ministerie van Economische Zaken et al., 2005: 5).

[t] he Antennebureau had been established back then to answer questions about the antenna policy and about more technical issues. Since mid-2004, the number of questions and complaints about the topic antennas and health has grown strongly (Tweede Kamer, 2005).

These observations affirmed the government's risk-based approach in dealing with siting controversies. Nevertheless, by the mid-2000s, the funding of research into health risks from RF EMF had caused quite some controversy, and even deadlock. In 2005 and 2006, around 70 municipalities decided to install a moratorium on the siting of masts until science had provided more clarity on health risks. This controversial episode started in 2002, when the government decided to fund a study into UMTStechnology and health risks, the TNO study, after Parliament had demanded more research into health risks from base stations (see chapter 4).

\section{The TNO study}

The results of the TNO-research project were ready to be announced in September 2003 (Zwamborn et al., 2003). In the beginning of their research report, the researchers explained how their study was directly informed by politicians' requests for more research:

[t] he parliamentarian Wagenaar submitted a motion during the consultation of the National Antenna Policy in which the government was asked to "initiate independent scientific epidemiological research into the effects of radiation from antennas on the long-term and to research the complaints made." (...) This study can be seen as a first answer to this motion and has therefore been given the research question to investigate the subjective complaints that were attributed to GSM base stations (Ibid.: 2).

The TNO researchers reported that their study - known as the COFAM (COgnitive Functions And Mobiles) study - showed a statistically significant decrease of feeling of well-being in the test subjects such as dizziness and concentration problems after being exposed to UMTS-like exposure. The fact that the researchers focused on UMTS-like exposure and not GSM-like exposure reflected the societal debate about mast siting that had shifted to UMTS. In the media, the researchers expressed their surprise at the study results (van Uffelen, 2003). In their double-blind laboratory experiment, two groups of people were exposed to electromagnetic fields similar as those coming from UMTS-antennas. The researchers measured the effects on physical 
well-being and cognitive performance. The researchers explained that the study's results were unique in that they showed a statistically significant effect from UMTSlike frequencies. Research with a similar design but with fields comparable to mobile phones (higher $\mathrm{V} / \mathrm{m}$ ) had already shown a decrease of cognition. The authors explain:

[i]n literature, it is speculated that that the effects on the cognitive parameters may be explained by an unknown mechanism induced by thermal effects. In our study, it is shown that the thermal effects are negligible and therefore, an explanation based on thermal effects seems highly unlikely for effects on the cognitive parameters (Zwamborn et al., 2003: 62).

They thus proposed more research into this area and a replication by other scientists of their study to see whether this study was just an anomaly or 'false positive', i.e. the null hypothesis ('no effect of EMF on health') had been incorrectly rejected. In other words, the COFAM-study had shown a relationship between UMTS-like exposure and a decreased feeling of wellbeing, but in reality, there was none.

The Minister of Economic Affairs agreed that more research was needed but saw no need to stop the planned rollout of the UMTS network because of the study's results. He announced that he would support initiatives by foreign research institutes that planned to reproduce the COFAM study (Tweede Kamer, 2004b). In May 2004, the minister of Health, Welfare and Sport asked the Gezondheidsraad for advice on how to proceed with interpreting the COFAM-study results. He asked the Gezondheidsraad four questions:

- What is the Health Council's assessment of the quality of the COFAM study and what does the Council see as the best approach to replication of the study?

- Is it desirable that additional research is carried out and, if so, what particular points should that research address, bearing in mind the nature of research activities in progress elsewhere?

- Is 'perceived well-being' a sufficiently objective concept for the formulation of scientific conclusions?

- Does the diminution of 'perceived well-being' amount to a sufficiently serious effect on health to justifymitigating measures? (Gezondheidsraad, 2004: 36).

Three months later, the Gezondheidsraad informed the ministry that the design and implementation of the TNO study were of high scientific standards, but it had some comments on the interpretation of the data, including the validity of the questionnaire used to measure the participants' 'well-being'. The Gezondheidsraad also questioned the very notion of 'well-being' as a legitimate indication of an adverse health effect. The Gezondheidsraad did not find it necessary to take measures if there was a minor decrease in well-being, "for instance a certain degree of discomfort which does not lead to any mental or physical effects" (Ibid.: 11). It asserted that it depended on the definition of 'well-being', which, according to the World Health Organisation 
(WHO) is "a state of complete physical, mental and social well-being, and not merely the absence of disease or infirmity" (Ibid.: 11). The TNO researchers used this definition in their study. The Gezondheidsraad questioned this interpretation of the concept of well-being, because "based on this definition, any decrease in well-being should be considered an adverse health effect" (Ibid.: 11). The Gezondheidsraad's advice to the government as its science advisor differed: it claimed that "only when objective evidence is obtained of the generation or exacerbation of physical or mental symptoms, can it be said that a health effect is involved which requires mitigating measures" (Ibid.: 31). According to the Gezondheidsraad, the TNO study results were no reason to change the existing exposure limits since it was not possible to determine whether there was a causal connection between exposure to RF EMF and negative health impacts. It concluded its advice to the government by calling for more scientific clarity about the question whether exposure to UMTS-fields has a negative effect on wellbeing. The government followed the Gezondheidsraad's advice: it did not implement more mitigating measures, such as lowering exposure limits or halting the siting of UMTS base stations. Instead, the government agreed that more scientific research was needed and started deliberations with a consortium of Swiss universities and research institutes who would replicate ${ }^{32}$ the TNO study. A few months after the publication of the TNO-study, a new research project known as COFAM II started in Switzerland, which was partly funded by the Dutch government. ${ }^{33}$ This discussion on UMTS-antennas thus continued, while the discussion on GSM-antennas, of which there were at the time still many more compared to UMTS, quietened.

The TNO study is an example of regulatory science: it was performed with the goal of informing politics about possible health risks from wireless communication technology. Yet, the TNO study did not provide facts that could literally be translated to a policy context. It did not answer the question whether exposure to UMTSantennas was a public health risk or not. The study needed to be interpreted by policymakers. The government's reaction was one of hesitation and caution: it asked the Gezondheidsraad for an interpretation of the study results. In its request for advice to the Gezondheidsraad, the relevant ministries indicated that follow-up research was needed (Gezondheidsraad, 2004). They therefore asked advice on the best approach to replicate the TNO study and on which additional type of research should be carried out. The government also asked the Gezondheidsraad two political and value-laden questions about the objectivity of the concept of 'well-being' and the need for mitigating measures. These questions revealed the government's view of the problem, how it could be solved and which aspects were relevant. The Dutch government had

\footnotetext{
${ }^{32}$ Even though the Swiss researchers did more than just replicate the TNO study because they changed the research design, the government mostly talked about 'a replication' of the TNO study.

${ }^{33}$ COFAM I was funded by the government, the financing of COFAM II went through a Swiss institute. The academic article (Regel et al., 2006) says: "[t]he study was supported by Swiss Research Foundation on Mobile Communication grant A2004-0."
} 
classified the question of mast siting as a scientific, and not a political one, and thereby decided that scientists and scientific advisory bodies should resolve it. Even though the interpretative scope of the study was left completely in the hands of the Gezondheidsraad, the government's framing of the advice already showed that it was reluctant to accept the study's results at face value. The government approached the study with the assumption that it was a false positive. The solution was a call for more scientific research. The government thus not only relied on its experts, but also deflected its responsibilities to them, letting the Gezondheidsraad answer questions that in fact belonged to the political realm.

The Gezondheidsraad drew a boundary between what was an acceptable risk and what was not: it decided that a diminished feeling of well-being was not a serious health problem. ${ }^{34}$ The government portrayed this judgement as the best scientific interpretation of the TNO study, thereby classifying the results as not significant enough for policy interventions. However, as social scientists have argued for years, these risk assessment policy issues are value judgements that can be contested by other scientists and by public actors. The grassroots support group StopUMTS, for example, criticised the advice: "the Gezondheidsraad does not mind when people get dizzy or nauseous and get pain in the chest. The council will only revise its advice when it is objectively proven that people become medically ill or when they die" (StopUMTS, 2006b). The TNO study reinforced a value dispute about issues that were about science, in this case 'what is an acceptable level of risk for society'. Social scientists have claimed that such questions cannot and should not be solved by science alone. Yet, the Dutch government used science as scientism: scientific knowledge became the only authority that could answer policy questions. As the social science literature on regulatory science showed, the outcome of scientific research by itself does not compel policy action. In other words, it is impossible to get a clear answer to a normative question (what is the right policy decision) from a statement of fact (this study shows a decreased feeling of well-being after test subjects are exposed to UMTS-radiation). Nevertheless, the government laid its responsibility with science and science advisors.

\section{The 'Swiss' study}

By 2005 , the minister was awaiting the results of the COFAM II study, which by now had become known as 'the Swiss study', to see whether it could reproduce the positive findings of the TNO study. The government's reluctance to act upon the results of

\footnotetext{
${ }^{34}$ The Gezondheidsraad's boundary work and its position in political debates changes according to the topic, which is inherent to the council's way of operation (see Bijker et al., 2009). This means that the Gezondheidsraad could take a different approach in other advices. In an advice about the health impact of large airports (Gezondheidsraad, 1999), for example, the committee understands 'public health' to also include quality of life, in contrast to its position on the notion of 'well-being' in the TNO-study (see also Gezondheidsraad, 2010).
} 
the TNO study and to wait for the Swiss study resonated in media reports, where one could read that:

[m] inistries, municipalities, telecom operators and opponents of UMTS masts are anxiously looking forward to the Swiss research about the relation between radiation and physical well-being. (...) The ministry will determine its course concerning the siting of antennas amongst others on the basis of this research (Oirschot, 2006)

This position could also be witnessed during a documentary on mobile phones and base stations by the Dutch TV-channel VARA, in which it discussed the results of the TNO study. It asked the State Secretary of Housing, Spatial Planning and the Environment whether the rollout of the UMTS network would now be halted until more was known about possible health effects. The minister responded that he would not stop an important technological development on the basis of 'unclear views'. He awaited the results of the Swiss replication study (VARA, 2004). In parliamentary discussions and in a letter to parliament, the State Secretary had also said that the Swiss study could possibly be a basis for changing the antenna policy in the future (Tweede Kamer, 2004a, 2004b).

This rhetoric of anticipation of more answers from science was so pervasive that by the time that the results of the Swiss study were expected - spring 2006 - around 71 municipalities (out of 458 in 2006) halted all decisions on the siting of base stations, specifically for UMTS (Tweede Kamer, 2006c). In November 2005, the Minister of Economic Affairs together with the State Secretary of Housing, Spatial Planning and the Environment had already addressed the municipalities' reluctance to site UMTS base stations in a briefing to parliament. They then stated that "[t]he reason that is given for this reluctance is a lack of clarity about possible health effects of electromagnetic fields of antennas and the fact that they are awaiting the results of the Swiss replication study" (Tweede Kamer, 2005). City councillors and aldermen of municipalities all over the country considered it better to wait before making any decisions on siting permits for masts for wireless communication technology. In these discussions, the Swiss study was portrayed as providing the ultimate clarity on the issue of base stations and health.

In a meeting of the city council in Haarlemmermeer it was for example uttered that "[b]oth the industry, government and many suspicious residents are anxiously awaiting the results of a Swiss study that is expected to give more clarity" (Gemeente Haarlemmermeer, 2005). In Berkel en Rodenrijs, the city council did not want to allow new UMTS masts "before a Swiss research has proven that electromagnetic radiation from base stations is not dangerous for public health" (Eerst onderzoek, dan masten (Berkel en Rodenrijs), 2005). In Amersfoort, two political parties did not want any more UMTS masts to arise "until it is clear what the risks are for the health of the people living in the neighbourhood. (...) Research by order of the national government 
has to provide more clarity come next autumn" (Geen UMTS totdat risico's duidelijk zijn, 2005). And in Spijkenisse, one could read in the magazine of the municipality:

[e]ven though there is more and more research into health effects from radiation from GSM and UMTS antennas, a clear connection has still not been established. All eyes, also in Spijkenisse, are now turned towards a Swiss research that is currently taking place (Gemeente Spijkenisse, 2006).

Mobile phone operators accused local politicians of abusing the situation to win votes in the upcoming municipal elections. They also pointed out that, based on 2500 studies, the WHO had concluded that there was no reason for worry. The Swiss study should be put in that perspective, instead of now being seen as providing the ultimate clarity, according to the industry (de Rodij, 2006).

The long-awaited results of the Swiss study became available in June 2006. The researchers concluded:

[i]n contrast to a recent Dutch study, we could not confirm a short-term effect of UMTS base station-like exposure on well-being. (...) No conclusions can be drawn regarding short-term effects of cell phone exposure or the effects of long-term base station-like exposure on human health (Regel et al., 2006: 1270).

The State Secretary interpreted these results as discrediting the TNO study as a false positive. Because the Swiss study's design was "more detailed and more extensive", it had shown "with more power of expression that those effects [that were found in the TNO study] did not occur", according to the State Secretary (Tweede Kamer, 2006d). The State Secretary's feeling of relief by the Swiss study's results shone through his press release: "[n]ot the slightest effect of UMTS radiation on health" (Ministerie van VROM, 2006). In reactions in the written press, the minister spoke with certainty: "dozens of studies showed that UMTS radiation is safe on the long term" and "moreover, there is no scientific ground for doubt" (n.a., 2006a). The State Secretary did not ask the Gezondheidsraad to review the Swiss study, nor did he ask for more replications of the same study design. In the government's view, the Swiss study had proven that UMTS was safe and this was announced as such in a political statement to parliament:

I conclude that the current state of science, taking into account the results of the Swiss research, supports my viewpoint that the siting of UMTS-antennas is justified from a health perspective. After all, the preconditions of public health, environment and safety are fulfilled (Tweede Kamer, 2006b: 3-4).

The Swiss study became a cornerstone in the government's decision to continue with the siting of base stations, or at least, it was portrayed as such. The government portrayed the Swiss study as the ultimate judge to the question of the existence of health risks from RF EMF. There was no room for doubt, according to the minister: "the Swiss 
study ends all uncertainty and it shows no effect, not even a little" (Tweede Kamer, 2006d).

During my field research several years after the publication of this study, the 'Swiss study' was still mentioned by municipal officials for whom it represented proof of the legitimacy of the antenna policy. A municipal official in Maastricht, for example, said, "the famous Swiss study has shown that there is no danger" (Interview M7). The municipality of Westmaas informed its citizens that it agreed with the government's standpoint that "refers to a Swiss study into the radiation of UMTS masts. This study shows that the preconditions of public health, environment and safety are fulfilled" (Municipal official Binnenmaas, personal communication, June 28, 2012). Municipalities thus echoed the words of the State Secretary that were very clearly communicated after the publication of the Swiss study: the Swiss study had adequately demonstrated that the siting of base stations was harmless (if the siting conformed to the existing exposure limits).

Yet, the government also tapped into another image of science: that of science as a continuous quest for evidence. The image of science as arbiter stood alongside the image of science as vigilant guardian. This became evident in the government's repeated rhetoric of 'keeping a finger on the pulse' ('vinger aan de pols houden') by which was meant that it would keep track of scientific developments. The government intended to stay informed about new scientific developments that might point to possible health risks by way of its scientific advisors and institutions:

[t]he Gezondheidsraad and RIVM [National Institute for Public Health and the Environment] keep a close eye on the publication of new research results that might affect the assessment of safety of citizens. Through the previously announced research programme with ZonMw, for which I am currently preparing the assignment, I can emphatically keep a finger on the pulse for developments in this field (Tweede Kamer, 2006b).

In this statement, the government referred to its decision to fund ZonMW (The Netherlands Organisation for Health Research and Development) with 16.6 million euro to set up a multi-year research programme on EMF and health. The government often used the discourse of vigilance in the context of discussions about the antenna policy. Already in 1997, during the first political discussions about the antenna policy, the government had said, "[w]e will keep up with the scientific developments in the area of health effects of electromagnetic radiation so that the policy can be changed in case of new insights" (Tweede Kamer, 1997) (see Wireless communication technology in the local policy arena section in chapter 4). In parliamentary debates about the interpretation of the Swiss study, the State Secretary responded to critical questions, "the interpretations [of scientific studies] are not from the State Secretary himself, but based on the statements by the WHO and the Gezondheidsraad, who for that matter constantly keep a finger on the pulse" (Tweede Kamer, 2006c). 
After the government dismissed the TNO study as a false positive and decided to contribute to a replication of the study, the importance attributed to the Swiss study rose significantly. The government claimed that its results would directly influence policy decisions about base station siting. The public debate about mast siting turned to discussing the policy implications of scientific studies of health risks from RF EMF. Municipalities considered it better to wait for decisions on mast siting until the results of the Swiss study were known. The Swiss study became more than just another scientific investigation of possible health risks from exposure to wireless communication technology. It became the ultimate judge that decided on the continuation of an important national policy. When the Swiss study did not find a decreased feeling of wellbeing in its test subjects, the government claimed that the siting of base stations could continue. Others, however, disputed this decision.

\section{Disputing the TNO and Swiss study}

At first sight, the risk-based policy approach of the Dutch government to deal with the increasing public dissatisfaction with the siting of base stations - tackling the deficit of scientific knowledge - seemed to achieve the government's goal of continuing with the siting of base stations. However, it did not have a stabilising effect of ending the societal concern about siting that the belief in evidence-based policy implies. In fact, I argue that the risk-based policy approach led to a shift in the societal debate on mast siting because it facilitated the deepening of a focus on negative health effects. Public actors such as engaged citizens and grassroots support teams did not accept the science that the government posited as public authority knowledge, but disputed it. Using science as scientism led to a polarisation of the debate. Whilst the government continued to insist that its policy decision was based on the best available scientific evidence and that it kept track of the newest scientific insights, critical voices emerged about the way the Dutch government had portrayed the Swiss study as proof of safety.

The representatives of the GGD'en (Community Health Services) considered it necessary to remind the minister that the health complaints and concerns of citizens should be taken seriously - whatever the Swiss study's results (n.a., 2006b). In addition, the Swiss researchers themselves sent out a press release prior to the publication of their study to assert that their results were not a sufficient basis for policy decisions on the exposure to long-term RF EMF. Their study was only targeted to finding out about the effects of UMTS-like radiation on the well-being and cognitive functioning of test subjects exposed for short periods of time (45 minutes), the Swiss researchers said (n.a., 2005b). In the ensuing political debate, also some parliamentarians questioned the carefulness of the State Secretary's statement that "the Swiss study ends all uncertainty and it shows no effect, not even a little" (Tweede Kamer, 
2006d). A number of political parties emphasised the remaining uncertainties in scientific knowledge, such as the Green Party:

the limitations of the Swiss research are not explained. (...) Common sense compels to say that there is not a lot known yet about the effect of radiation. Internationally and on a scientific level, there are lively debates about long-term exposure (Tweede Kamer, 2005).

These parties called for precaution to be taken into account: "it seems sensible to $\mathrm{Mr}$ van Dam [Dutch Labour Party] to practice precaution by rolling out a network with less masts and less field strengths" (Ibid.). The Green Party also "expected from the government to express uncertainties and deal with them prudently" (Ibid.). They referred to other European countries that had decided to lower their emission standards. These actors thus challenged the government's depiction of scientific certainty. Creating doubt about the Swiss study was an achievable goal because of the government's use of the Swiss study as public authority knowledge, i.e. when "science goes beyond supplying the facts to defining the public meaning of problems" (Wynne, 2010: 441). The antenna policy was reduced to a question of whether the science was right or wrong. The politicians did not dispute the facts of the Swiss study, but the interpretation of it by the government. The Swiss study was disputed because the more the government tried to get robust scientific advice from its experts, the more it revealed the socially constructed nature of this knowledge and the inherent uncertainties.

Other societal actors besides politicians highlighted scientific uncertainties in the Swiss study. One month after the release of the Swiss study, the municipality of Spijkenisse - one of the most engaged municipalities - decided to continue with the restrictive siting policy and not hand out any building permits for UMTS base stations because "it was not clear what the health risks are for the long term. The much talked about Swiss study only gives a decisive answer about exposure to radiation over a very short period" (Gemeente Spijkenisse, 2006). The city council had asked the group of engaged citizens in Spijkenisse to give their view on the Swiss study. 'Spijkenisse against Radiation' criticised the Swiss study on several grounds: the methodology did not take into account the real-life continuous, long term and ubiquitous exposure to RF EMF and they considered it suspicious that the full results of the study were not disclosed (Interview S1). For these engaged citizens, the Swiss study represented the government's negligence of all those other scientific studies that did show health effects (Interview S1 \& N8). Even many years later, during my field research, the Swiss study was still cited. For example, in a newspaper article about a group of engaged citizens in Rijen (NL), the journalist quoted one of them as saying: "[the mast] involves health risks. Various studies have shown that, but the municipality hides again behind those studies that speak to their advantage, like the Swiss study. That study is totally unsound" (Huijben, 2008). A representative of the Antennebureau also mentioned that the Swiss study often came up during information sessions as an accusation of 
the government's narrow-mindedness concerning the broad array of evidence for health risks (Interview N9). The GGD also discussed the TNO and Swiss study in its presentations during information sessions for citizens (see section Trickling down the antenna policy in chapter 4).

The critique of politicians, municipalities and engaged citizens on the Swiss study echoed the opinion of grassroots support teams. StopUMTS (2006a), the best known grassroots support team in the Netherlands (see chapter 3), commented on the Swiss study by first of all stating that the study was irrelevant - a "simple provocation study" - since only epidemiological studies (study of disease patterns in human population) could answer the question whether exposure to RF EMF is harmful on the long term. Yet, taking a closer look at the Swiss study also revealed numerous other defects, according to StopUMTS. Firstly, it was thought "surprising" that the scientists did not use a UMTS base station in the laboratory, but a frequency generator that generated a signal only "resembling" that of a base station. This situation was far from similar to reality in which movies, conversations and websites "fly through the air", the argument continued, leading to a much less dense signal compared to a real-life situation. Secondly, the research did not take into account the participants' exposure to radiation prior to coming to the lab. This was believed to be problematic, since before the test, "when participants walk through the university building where they for example develop heart palpitations due to exposure to radiation from WLAN transmitters, they then will probably still have these during the research in the laboratory" (StopUMTS, 2006a). In fact, the Swiss society for electrohypersensitivity Gigaherz asked its members to come forward if they participated in the research. The society claimed that four participants reported that they all became so ill that they had to withdraw from the study. Thirdly, the research only asked participants who "did not smoke, drank little coffee and alcohol, slept well, were not fat, left-handed or younger than twenty or older than sixty and were not ill" (Ibid.). The results could thus only account for a minority of the population. StopUMTS concluded the review by stating that "the high standards that the Gezondheidsraad imposes on telecom critical studies were apparently not applicable to the Swiss study, which nevertheless has played a decisive role in the political acceptance of the UMTS rollout and still has in surrounding jurisprudence" (Ibid.)

The same points of criticism on the scientific standards were already voiced in 2004 by another grassroots support team called Stichting Milieuziektes (literal translation: Foundation Environmental Diseases), active online and through a newsletter (Stichting Milieuziektes, n.d.). Since 2001, the Stichting focused on diseases from the environment, be that electromagnetic fields or any other 'polluter' in the water or air. In 2003, it devoted several pages of its newsletter to scrutinising the TNO study. Even though the TNO study found a negative effect on health (in terms of well-being), and thus backed up the Stichting's goal, the organisation nevertheless found a number of 'technical problems' that could be summarised in one overarching critique: the study 
was not representative of the real-life conditions that people are exposed to. Like the comments of StopUMTS on the Swiss study, the Stichting also commented on the fact that the scientists used a frequency generator, whose signal was not comparable to a normal base station signal, or that the data traffic that takes place in normal circumstances (videos, conversations, etc.) was not taken into account. The Stichting deemed it important to simulate a real practical situation that takes into account the exposure in everyday life, for example in big cities, where people are exposed to a mixture of technologies, such as GSM, UMTS and Wi-Fi. The TNO study did not take into account this cumulative effect of long-term exposure to RF EMF, concluded the Stichting.

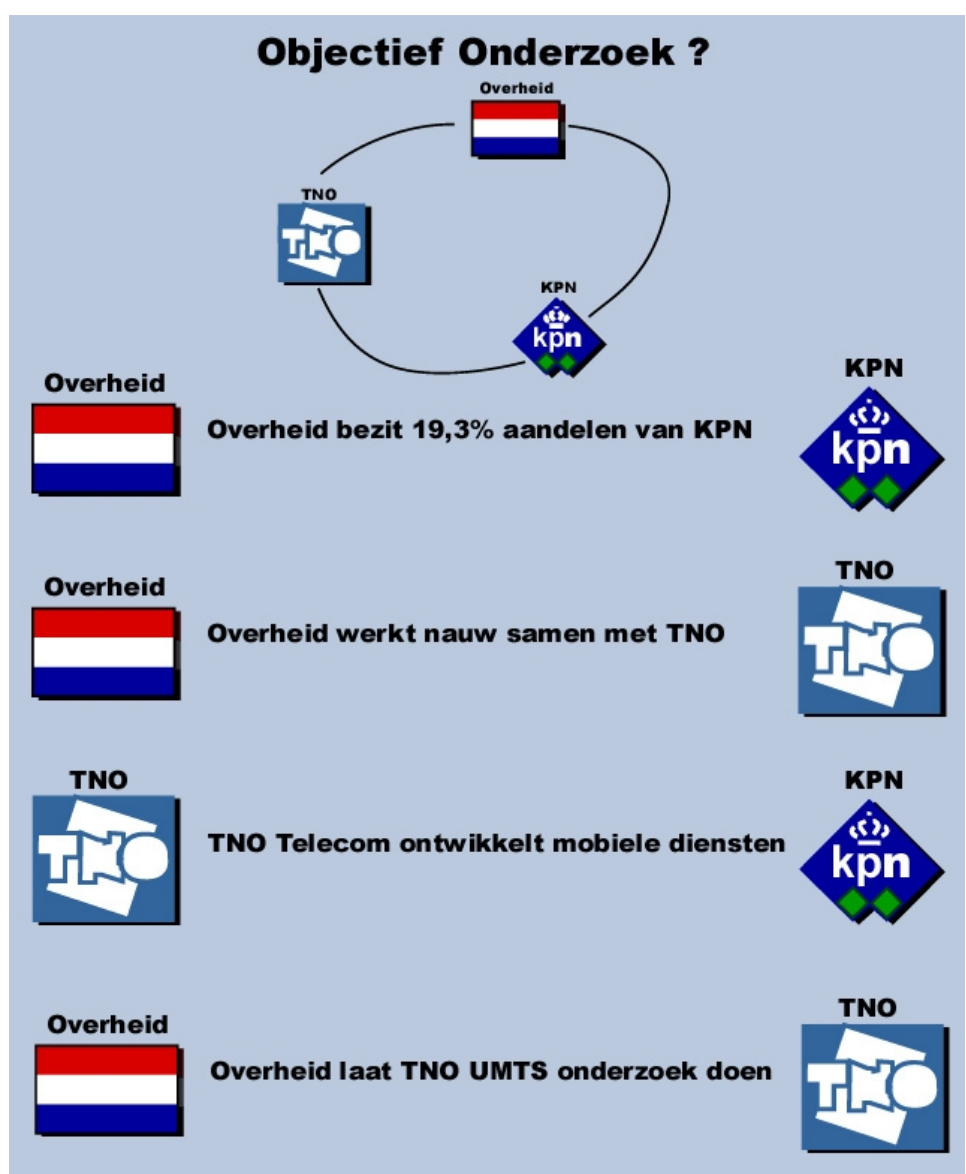

Figure 5.1. - "Conflict of interest government, TNO and providers?". The title reads "Objective Research?". The government is portrayed by the Dutch flag, the research institute TNO by its light blue logo and the mobile phone operator KPN by its dark blue logo. It reads from top to bottom: "Government has $19.3 \%$ shares in KPN", "Government works closely together with TNO", "TNO Telecom develops mobile services", "Government instructs TNO to conduct UMTS research" (StopUMTS, n.d.) 
The grassroots teams' analysis did not stop there. Another part of their comments focused on the alleged impartiality of the institutions performing the research. StopUMTS accused TNO of conflict of interest because of its presumed shared interests with the government and a mobile phone operator (KPN) (see Figure 5.1.). In their self-explanatory picture, StopUMTS reasoned that the study had to be discredited since 1) the government held shares in the telecom company, 2) the government collaborated closely with TNO, 3) TNO developed mobile services for the telecom company and d) the government funded TNO to do a study into RF EMF. In the following years, the members of StopUMTS also tried to discredit certain members of the Gezondheidsraad's committee that prepared reports on RF EMF, asserting that some had close ties with industry, delegitimising their advisory role in the council - and thus undermining the authority of the Gezondheidsraad's advises on wireless communication technology. The same rhetoric of the untrustworthiness of government, industry and scientific institutions resonated in StopUMTS' reaction to the publication of the Swiss study. A law firm closely related to StopUMTS appealed against the ministry's decision and demanded the full disclosure of the data on which the Swiss study's results were based. The ministry replied that the information was already publicly available, as a peer-reviewed publication in the academic journal Environmental Health Perspectives. In further correspondence, it replied that the Swiss research consortium owned the property rights of the raw data and other scientific information on the study. The project leader of the Swiss study only allowed access to fellow researchers within a scientific context. ${ }^{35}$ The same suspicion and surprise at the lack of openness was still uttered years later during the interviews I had with engaged citizens that affiliated with similar grassroots support team as StopUMTS (Interview S1). The ties between science and industry were also a recurring theme in mast siting controversies (see chapter 3).

The fact that the government insisted on portraying particular studies as evidence of the harmlessness of wireless communication technology encouraged public actors to dive deeper into the scientific aspects of mast siting. The TNO and Swiss study became iconic studies on the websites of grassroots support teams, as they were considered to represent the government's mismanagement of the antenna policy. Interest groups, such as the Stichting ElektroHypersensitiviteit (Dutch ElektroHyperSensitivity Foundation (EHS)) and grassroots support teams, such as International EMF Alliance (see Table 3.2. in chapter 3), also started to interact with academics, for example, by attending academic conferences on the topic of EMF. ${ }^{36}$ As

\footnotetext{
${ }^{35}$ All the documents and correspondence on the disclosure of the data of the Swiss study can be found at http://www.StopUMTS.nl/doc.php/Reacties/1293, archived at http://www.webcitation.org/6Q6ZxRI6t.

${ }^{36}$ At the conference Low frequency electromagnetic field exposure and modulation of cellular functions, organised by the University of Wageningen (NL) and ZonMw in September 16, 2010, there was at least one person from a grassroots support team present. Also at the mini-symposium Modern health worries and idiopathic environmental intolerance in relation to symptoms. Research, assessment and treatment options, organised by the RIVM in Utrecht, February 1, 2011, people from Foundation EHS, Werkgroep Hoogspan-
} 
I discussed in chapter 3, grassroots support teams backed up citizens' engagement around mast siting, amongst others, by providing a plethora of information on their websites. In the period of the public and political discussion on the Swiss study, engaged citizens took over their criticism on the government's interpretation of particular studies (as was the case in Spijkenisse). The comments of these groups on scientific studies reflect the STS-insights about the public understanding of science. Public actors did not misunderstand what the Swiss study (or any other study) had researched. Their criticism did not originate from a lack of intellectual capacity to understand science. Rather, these different publics criticised those aspects of public science that they deemed equally important as the actual content of the knowledge itself, more specifically, the context in which the knowledge was made, the purposes of this knowledge and the policy interpretations of this knowledge. As the STS-literature on public understanding of science has shown, public actors evaluated the outcomes of science in the light of their own knowledge and experiences. Some had access to experiential knowledge about the effects of exposure from wireless communication technology on people's health. Some also took a critical look at the institutions, scientists and advisory bodies that presented and interpreted this knowledge.

The formulation of the Swiss study as proof of safety shifted the public debate to one about the merits of scientific studies. The government aimed for a rational approach to base station siting that was based on scientific evidence. This became especially evident in its relation to the municipalities that had postponed all building decisions for UMTS-masts between the publication of the TNO and Swiss study. The government told them that there were no grounds anymore to ban the siting of base stations. In a newspaper article, the government was quoted as saying: "[w]e don't live in a banana republic and the national government determines the rules on this domain" (n.a., 2006a). In June 2006, after parliament debated the Swiss study, the government parties also gave their full support to the responsible ministries for the continuation of the antenna policy. They did not consider it appropriate for citizens and municipalities to continue to engage with the siting of the technology. As one Member of Parliament put it in the newspaper, "[w]e can understand that people are concerned. But at a certain moment one must accept that there are studies whose outcomes may be considered reassuring" (VNG, 2006b). Government parties agreed that municipalities - and especially those that continued to refuse siting base stations - had to reconcile themselves to the facts and the democratic decisions taken, which were informed by those facts: "[h]ard scientific facts show that there is no reason for concern. Municipalities must reason from these facts and take away the societal concern instead of feeding it" (Tweede Kamer, 2006c).

ning (working group high tension (ELF)) and International EMF Alliance were there. Moreover, interviewees that were involved in grassroots support teams would travel often to attend international conferences. 
The government reasoned that science had been the judge, and had decided that nobody should be concerned about health risks. For the government, this meant that mast siting controversies were not to be tolerated. The government reinforced its position as the authority in charge and condemned municipalities that did not follow its policy. I discussed in the previous chapter that the antenna policy did not allow much involvement of local authorities in siting decisions (see chapter 4). Some municipalities had temporarily reclaimed their rights of deciding on local planning of masts by arguing that they had to wait for scientific clarity about possible health effects from UMTS-exposure. In the view of the government, the Swiss study had provided this answer and it thus gained the upper hand again in the dispute with the local authorities. At the end of the 1990s, when the rollout of the wireless communication network had just begun, the disagreements between the local and national governments about siting antennas focused largely on urban and country planning aspects. Municipalities were concerned that the proliferation of antennas would lead to landscape pollution (see chapter 4). During the episode of the TNO and Swiss study, this focus shifted to a question of public safety: did the antennas harm citizens' health? Some municipalities now used scientific arguments to question the antenna policy. Engaged citizens did the same. Other reasons for engaging retreated into the background. All actors in the controversy now focused on one issue that had become pivotal in the antenna policy, i.e. the existence of health risks. Counter-expertise to the government's view on science came from the contact with societal actors who were not engaging against the siting of a particular base station, but who engaged against the proliferation of wireless communication technology in general: the grassroots support teams (see chapter 3). This shift in the societal debate about base station siting polarised the different positions. Moreover, in the public debate, the position of the more radical grassroots support teams moved to the foreground, whilst the local citizen collectives, and their concerns, moved to the background.

\section{The misguided belief in science as a solution to mast siting controversies}

I discussed the (co-)funding of the TNO and Swiss study as products of the government's risk-based approach in dealing with mast siting controversies. The government depicted mast siting controversies primarily as instances of citizens' fear for health risks. From this perspective, its investment in more scientific knowledge seemed to be a "logical reflex", as someone from the GGD phrased it in an interview with me (Interview K7). It might seem rather innocent to ask scientists to try to find out what is going on so that politics and society can get more clarity on the issue. However, as the STS and policy science literature has indicated, it becomes a real problem when scientific knowledge is used as scientism or as public authority knowledge (Wynne, 2008). Also in the controversies I studied, the resort to science had effects. The government represented the Swiss study as knowledge that had the authority to decide on the 
legitimacy of the public controversy of mast siting. Yet, using science as an arbiter did not appease the controversy, but led to fundamental disagreements about the interpretations and implications of scientific results. I argue that the risk-based approach of the government shifted the discussion about base station siting from dissatisfaction with local siting regulations to a polarised debate about the existence of health risks from RF EMF. Science went from judge to being judged. Critics of the government's policy highlighted uncertainties, contested the scientific interpretations and accused scientific advisory bodies and scientists of bias.

The government assumed that more science would provide solid knowledge on which to base policy decisions. Moreover, it also assumed that science would end the public debate. Yet, my analysis of mast siting controversies and the use of regulatory science revealed several flaws in using and portraying science as the solution to mast siting controversies. Firstly, I showed that public concerns about base station siting were not just concerns about health risks (see chapter 3 ). The government thus did not address all of the underlying issues of mast siting controversies. The public discussions about mast siting involved questions about risks (and thus science), but it was not a purely risk nor scientific issue. Many non-scientific aspects contributed to citizen engagements: the question of citizen involvement in the decision, the question of adequate local planning, the question of landscape pollution, etc. The ability to have a say in whether and where the mast would be sited remained a prime concern for citizens (see chapter 3 and 4 ). On the other hand, in this chapter, I demonstrated that science-informed arguments became much more central in public discussions on mast siting and wireless communication technology throughout the 2000s. I argue that the risk-based approach of the government contributed to this narrowing of the public debate on mast siting.

Secondly, in this chapter I discussed how science as scientism led to increased critique on scientific practices, scientists and scientific advisory bodies. These discussions meant a further polarisation of the views on mast siting. Science became the battlefield to argue for or against mast siting. Policy solutions to this situation were sought in better explaining the scientific aspects of wireless communication technology, which further reinforced the debate on the science involved. Again, the policy solution to mast siting moved further away from the other issues that triggered siting controversies. The problem was thus extracted from its local context. The local mast siting controversies had become a national problem of scientific knowledge, foregrounding grassroots support teams.

\section{The presumed deficit of information}

Next to investing in scientific knowledge, the Dutch government also announced to tackle the increasing number of mast siting controversies with more communication about health risks from exposure to base stations. During and after the discussions 
about the Swiss study, all political parties (Tweede Kamer, 2006c), the representative organisation of the Dutch municipalities (VNG) (VNG, 2005) and mobile phone operators (Tweede Kamer, 2006a) criticised the government for its lack of good communication about the antenna policy to the public and municipalities. In parliamentary debates, "insufficient communication" was believed to be "one of the causes of public concern" (Ibid.). Parliamentarians wanted "the societal unrest [to] be addressed with sincerity" (Tweede Kamer, 2006c). The government agreed that communication was a point of improvement. When the Swiss study was published in June 2006, the State Secretary of Housing, Spatial Planning and Environment said, "the recent societal controversy about health aspects of antennas shows that there is a need for clear information" (Tweede Kamer, 2006b). Some months later, the Minister of Economic Affairs reiterated this point in VNG Magazine: "better knowledge with municipal officials and better information to citizens could avoid problems" (VNG, 2006a).

According to the Minister of Economic Affairs, the problem of public understanding of science was twofold: people not only had difficulty finding, but also understanding 'correct' information about EMF and health:

[i]t is important that people who get involved in base station siting can easily find accurate information about this topic. The relationship between electromagnetic fields and (un)known possible effects thereof on health is a complex matter. Trust in the source of information plays a big role with regard to conviction and credibility (Ministerie van Economische Zaken et al., 2005: 5).

The minister's referral to the "trust in the source of information" points to the third problem of public understanding of science that the government identified: the arguably dubious quality of information about health aspects from RF EMF that public actors read. In the second evaluation of the antenna covenant in 2005, the different parties (ministries, VNG and mobile phone operators) said, "during the last period a lot of information has been published on the Internet. The quality of this information is however varying, absolutely anything mixed together. This can lead to confusion and concern" (Ministerie van Economische Zaken et al., 2005: 7). This incited the convenant parties to "remain active in providing and making accessible realistic information" (Ibid.). The general secretary of the Kennisplatform EMV \& Gezondheid (Kennisplatform EMV\&G; Knowledge Platform EMF \& Health) also used the notion of "realistic knowledge" in describing the goal of the Kennisplatform (Interview K1), another arrangement that was established in the aftermath of the political discussion about the TNO and Swiss study.

This broad knowledge platform on EMF and health was established as an information and communication point to ensure that "scientific knowledge [would] be made accessible in a swift, objective and independent manner and [would] be communicated to the different societal actors, amongst which the media" (Tweede Kamer, 
2005). ${ }^{37}$ It was an initiative of the National Institute for Public Health and the Environment (RIVM), the research organisation TNO, the GGD (Community Health Services), the Netherlands Organisation for Health Research and Development (ZonMw), the energy consulting and testing and certification organisation (KEMA) and the Radiocommunications Agency Netherlands (Agentschap Telecom). The Gezondheidsraad had an advisory role. It started in 2007 (with refunding for the years 2011-2014) and was linked to the government's 16.6 million euro investment in a research programme on EMF and health (see 5.3.2.). In its letter to parliament after the publication of the Swiss study results, the State Secretary of Housing, Spatial Planning and Environment referred back to the Kennisplatform after mentioning that the siting of base stations was "justified from a health perspective": "I deem it my duty to inform society. The previously announced independent Kennisplatform Elektromagnetische Velden en Gezondheid can play an important role in that" (Tweede Kamer, 2006b).

The establishment of the Kennisplatform fitted into the government's assumptions about the need for risk communication, i.e. public actors had a hard time understanding EMF science and public actors mostly had access to biased sources of knowledge:

[t]he backgrounds of electromagnetic fields and the interpretation of the results of scientific studies on EMF are usually too complex for laypersons to be able to form a thorough opinion. In addition, to an increasing degree there is information available on the Internet, of which the quality and reliability is difficult to assess for those interested without scientific expertise in this area. An additional problem is that in a number of cases, qualitative reliable information is provided with scientifically not justified and thus (unintentionally) misleading interpretations (Kennisplatform Elektromagnetische Velden en Gezondheid, 2008c: 9).

Even though the government intended to "inform society", it did not address citizens directly, but acted through what it called 'intermediaries' such as municipalities, GGD'en, mobile phone operators, housing corporations and other professionals coming into contact with citizens. They formed the 'frontline' of the government's plan of better information provision. As I discussed earlier, according to the government, these intermediaries (especially municipalities) also suffered from an information deficit, and thus contributed to citizens' confusion about the existence of health risks.

\footnotetext{
${ }^{37}$ See www.kennisplatform.nl. When speaking about the Kennisplatform, I will use the past tense for reasons of readability, even though the Kennisplatform still existed at the time of writing (June 2014). Its future, however, was then uncertain. The analysis of the Klankbordgroep and Kennisplatform are based on interviews and participant observations of several meetings, see section The research in chapter 1 and Appendix 2.
} 


\section{Risk communication through intermediaries}

At the end of 2005, the government's strategy was to provide the local actors standing in direct contact with citizens, and thus receiving questions from them, with the 'right' knowledge to communicate through the Antennebureau and the Kennisplatform EMV\&G. All municipalities received a letter to explain the antenna policy in detail and special one-day courses for municipal officials dealing with the latest scientific insights, the exposure limits and the communication concerning the exposure to EMF were organised in 2005-2006 (Tweede Kamer, 2005). The government wanted municipalities to have the official information at their disposal to ensure that "the feelings of unrest" of the citizens asking questions would be "addressed and channelled" (Ibid.). In order to "help municipalities to discuss this topic in a rational and balanced way" (Ibid.), the government decided to strengthen the Antennebureau's role to make sure that it could continue with offering municipalities the possibility of organising an information session. Such sessions were perceived as "most suited to the needs of citizens for information, explanation and the feeling of "being heard'" (Tweede Kamer, 2005; see previous chapter for a discussion on the information sessions provided by the Antennebureau).

In the previous chapter, I argued that these information sessions did not fit with citizens' expectations. They wanted to discuss the local siting of a base station in their neighbourhood, but the meetings were set up as opportunities for information provision about health aspects from siting to citizens. The sessions fitted in the government's assumption of a lack of knowledge on the part of citizens. Yet, as I argued in chapter 3, most citizens did not lack information, on the contrary, they managed to find plenty of knowledge about mast siting with which to make an informed decision. The information sessions were organised as opportunities of information dissemination to either an ignorant or a misinformed public (see chapter 4).

Despite the identified need of citizens for "direct and interpersonal communication", the government's overall communication strategy about the antenna policy was not targeted at individual citizens. It did not invest in a national information campaign because of the idea, expressed in 2002, that "information about base stations was only desired by individuals who are directly confronted with a base station" (Antennebureau, 2002: 16; see section The antenna policy: calls for better public information in chapter 4). In 2006, the government still found that a public campaign would "raise more questions than give answers" (Tweede Kamer, 2006c: 6). The two bodies in charge of communicating about EMF, the Antennebureau and the Kennisplatform, did not directly target communication to citizens, but to intermediary professionals. The Kennisplatform wanted to "contribute to social debate by providing clarity" by making sure that the agencies and authorities who had daily contacts with concerned citizens received regular information on the publication of scientific studies 
and other developments in the field of EMF and health (Kennisplatform Elektromagnetische Velden, n.d.).

In the government's view, communication about EMF and health to 'the public' meant ensuring that local authorities and local partners did not suffer from an information deficit. Citizens only needed to be informed when they asked questions to these actors, or when they were confronted with the siting of a base station. The government wanted to have a rational discussion about scientific facts, through intermediaries who targeted specific citizens. The establishment of the Kennisplatform fitted in this dual strategy of a purposive rational discussion. 
Table 5.1. - A list of organisations that accepted the invitation by the Kennisplatform for the first Klankbordgroep meeting

Stichting Elektrohypersensitiviteit (ESH)

Dutch ElektroHyperSensitivity Foundation (EHS)

Meldpunt Gezondheid en Milieu

Dutch Organisation for Monitoring Health and

Environment

MoNet (Mobiele Netwerkoperators Nederland)

Dutch Mobile Network Operators

TenneT

Nederlands Instituut voor Bouwbiologie en Ecologie (NIBE)

The Dutch Institute for Building Biology and Ecology

Nationaal Platform Stralingsrisico's (NPS)

National Platform Radiation risks
The foundation is a contact point, information centre and interest group for people suffering from EHS. Its mission is to accomplish a life as normal as possible for elektrohypersensitive people. It calls for the recognition of EHS as a disease.

Environmental organisation that strove for a clean and safe environment without pollutants. It recorded cases of environment related health complaints such as electromagnetic fields. It seized to exist in 2012

MoNet is a collaboration between the three Dutch mobile phone operators to collectively defend their interests in discussions with the government, municipalities and other societal actors. It is also involved in information provision.

TenneT is the national electricity transmission system operator of the Netherlands (the Klankbordgroep also discusses low frequency electromagnetic fields)

NIBE is the representative of the building biology movement in the Netherlands. It is a consultancy in the area of environmentally friendly and healthy building. It does research, advises and designs buildings that live up to these standards. Electromagnetic fields are also part of the built environment. It also represents a growing profession of woonbiologen: those that measure EMF and other possible indoor 'pollutants' to help people with health complaints.

The NPS is a grassroots support team that wants to bring the negative health effects from EMF to the attention of the Dutch public and government. It wants to contribute to a public discussion.

The NVMBR is the professional association for people who work in hospitals with radiation in any form (radiology, radiotherapy, ultrasound and MRI). It develops guidelines concerning safety of working with EMF.

StopUMTS is a grassroots support team active online. Through its website, it offers a plethora of information on EMF, with a focus on scientific studies. 


\section{Participation of societal actors}

The Kennisplatform, however, did not only communicate to intermediaries but also asked a specific group of public actors to participate in its Klankbordgroep or Sounding Board (see pictures 5.2 \& 5.3). The Sounding Board provided "societal groups and representatives of interest groups with the opportunity to share their questions and concerns related to electromagnetic fields" (Kennisplatform Elektromagnetische Velden, n.d.). This meant that the Klankbordgroep hosted several societal actors with different and conflicting goals and interests, such as mobile phone operators and MoNet (Mobile Network Operators the Netherlands), radio amateurs, the interest group of people with electrohypersensitivity (EHS), the institute representing building biologists and ecologists (Nederlands Instituut voor Bouwbiologie en Ecologie, NIBE), and a few grassroots support teams (such as StopUMTS and Nationaal Platform Stralingsrisico's, NPS) (see Table 5.1). The Kennisplatform aimed to become "wellinformed about [societal] questions and concerns and, thus, (...) to contribute to a clear social debate on the most relevant subjects" (Kennisplatform Elektromagnetische Velden, n.d.). A staff member of the Kennisplatform explained the Klankbordgroep as "(...) a means to start a dialogue with all concerned parties, with the field; to hear what is going on, what are the questions, how are messages received and understood?" (Interview K6).

The Kennisplatform primarily invited organisations that dealt with health issues of EMF in different ways: "[i]n particular, those organisations [were] invited that have a relation to the health aspects of electromagnetic fields" (Kennisplatform Elektromagnetische Velden en Gezondheid, 2008c: 27). Local citizens thus moved to the background. The Klankbordgroep was portrayed as a way to learn how to deal with risks in society, according to its secretary. In his view, scientific knowledge played a crucial role in this process: it was important to see what society thought about these risks, and to take those insights to science, instead of the other way around (Interview K1). The Klankborgroep actors were thus supposed to represent the "voice of society" or the "social conscience" in the Kennisplatform (Kennisplatform Elektromagnetische Velden en Gezondheid, n.d.). Yet, I would argue that these actors only represented a small part of society, i.e. those that were highly concerned about the negative health impacts from RF EMF, and hence those that felt at ease with the health risk framing. It was not society speaking to the Kennisplatform but societal groups with particular interests in curtailing the development of wireless communication technology.

As the title of the Kennisplatform already suggested (kennis translates as knowledge), the main theme under discussion in the Klankbordgroep was scientific knowledge about possible health risks from RF EMF (and ELF EMF). During a typical meeting, scientists from the ZonMw programme on EMF and health presented their on-going work, and interest groups or grassroots support teams presented recent 'societal developments' such as scientific studies that show negative effects from RF 
EMF, policy changes in other countries and experiential stories of electrohypersensitives. Klankbordgroep members were encouraged to keep the discussion on a scientific level. If members wanted to spent time on a topic, the board would say, "we can pay attention to it if you give new scientific viewpoints". I argue that the lengthy discussion of scientific knowledge in the Klankbordgroep had two effects. Firstly, it reinforced the dichotomy between two groups of actors: 'the believers' and 'nonbelievers' of health risks, or 'opponents' and 'proponents' of wireless communication technology, as the actors involved labelled these groups (Interview K3 \& K7). Secondly, it exposed the underlying political and value-laden aspects of scientific knowledge, which were a challenge for the Kennisplatform to manage. The Kennisplatform created a boundary between science and politics. It positioned itself as only dealing with the scientific issues, and not with politics.
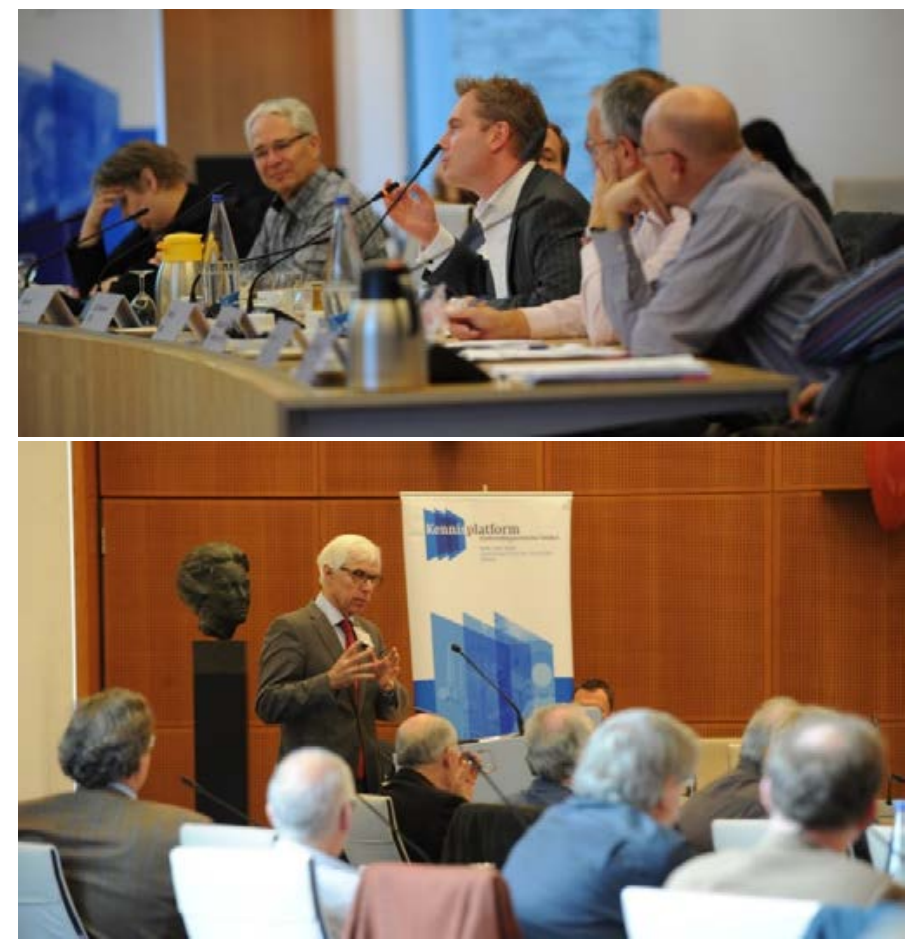

Pictures 5.2 \& 5.3 - A meeting of the Klankbordgroep (Sounding Board) of the Kennisplatform EMV \& Gezondheid (Knowledge Platform EMF \& Health). Photographs by the Kennisplatform EMV \& Gezondheid. 


\section{Debating science in society: reinforcing the dichotomy}

After a few years into the existence of the Klankbordgroep, it seemed to be stuck in a ritual in which those convinced of the negative health effects of RF EMF tried to convince those who did not agree. The discussion on science with a wide range of societal actors had led to the entrenchment of the contradicting views on science and EMF. A staff member of the Kennisplatform explained:

[y]ou see that that it creates more and more distance between each other. They [members of Klankbordgroep] listen less to each other and are less driven by arguments. If they already have very strong beliefs [and] there is new information, they pick the things that fit their beliefs and use them to strengthen their own opinions (...) Scientific information about the causes [of negative health effects] is never going to bring people closer together, because it can always be interpreted in different ways (Interview K7).

My analysis shows that the disagreement between the different positions on the existence of health risks came down to different interpretations of science, in particular on what sort of scientific research should be done, how it should be interpreted, and how society should act upon the scientific insights gained (compare Brown et al., 2006; see Table 5.2). The discussions in the Klankbordgroep showed that far from being an apolitical activity, discussing science in society revealed normative choices and commitments that were commonly defined as 'scientific' and thus perceived as being the privilege of scientists alone. Discussing 'science' went right to the heart of political and normative issues such as 'Who decides when to take precautionary measures?', 'At what cost should we protect vulnerable groups in society?', and 'How to deal with gaps in knowledge?'

Societal actors wanted scientists to investigate 'real life' situations instead of controlled experimental settings, which they claimed were unsuited for electrohypersensitives (belongs to the scientific process of 'doing scientific research', see Table 5.2.). Societal actors also argued that the uncertainties in scientific knowledge should be the basis for precautionary measures, whilst the government argued that precaution was taken by funding more scientific research (belongs to the scientific process of 'acting on science'). In the setting of the Klankbordgroep, the same issues were raised by grassroots support teams and other societal actors critical of the government's view on EMF science. Instead of voicing these concerns online or in newsletters, they could now address scientists directly. As a result, ZonMw scientists often ended up defending the methodologies and interpretations of their studies after receiving critique from the societal groups. Most scientists were very open and willing to discuss the social relevance and implications of their work, even though on occasion, the societal groups' critique was hostile and depreciatory. This was especially the case with psychological research projects that looked into people's perceptions of health 
risks from mobile telephony. Societal organisations did not consider these studies to be relevant, because researchers assumed that EHS was a psychological problem. The societal organisations participating in the Klankbordgroep refuted this and demanded more studies into the causal mechanism of health complaints from exposure to RF EMF.

Table 5.2. - The table displays the differences in opinion about the processes of science, in particular related to doing scientific research, interpreting scientific research and acting on science.

\begin{tabular}{|c|c|}
\hline SOCIETAL VIEWS & EXPERT VIEWS \\
\hline $\begin{array}{l}>\text { represented by grassroots support teams \& interest } \\
\text { groups }\end{array}$ & $\begin{array}{l}\text { > represented by ZonMw scientists, the } \\
\text { Gezondheidsraad \& the Kennisplatform }\end{array}$ \\
\hline \multicolumn{2}{|l|}{ I. Doing scientific research } \\
\hline $\begin{array}{l}\text { Experiential knowledge of electrohypersensitives is } \\
\text { the basis of research projects }\end{array}$ & $\begin{array}{l}\text { Scientific research needs clear parameters, design } \\
\text { and tools. Cases of EHS are too messy. }\end{array}$ \\
\hline $\begin{array}{l}\text { Investigate 'real life' situations of people being } \\
\text { exposed to EMF }\end{array}$ & $\begin{array}{l}\text { Provocation studies in a (double-blind) controlled } \\
\text { experimental laboratory setting are the best way to } \\
\text { find out whether people react to exposure or not }\end{array}$ \\
\hline \multicolumn{2}{|l|}{ II. Interpreting scientific research } \\
\hline $\begin{array}{l}\text { Grey literature (which is understood as non-peer- } \\
\text { reviewed scientific documents such as conference } \\
\text { proceedings and reports) is included in scientific } \\
\text { deliberations }\end{array}$ & $\begin{array}{l}\text { Strict protocols for meta-analysis of scientific studies } \\
\text { ensure scientific quality (peer-reviewed is one of } \\
\text { them) }\end{array}$ \\
\hline $\begin{array}{l}\text { Weight of evidence: false negatives (Type II error) } \\
\text { should be avoided (failure to reject a false null } \\
\text { hypothesis) }\end{array}$ & $\begin{array}{l}\text { Weight of evidence: false positives (Type I error) } \\
\text { should be avoided (the incorrect rejection of a true } \\
\text { null hypothesis) }\end{array}$ \\
\hline \multicolumn{2}{|l|}{ III. Acting on science } \\
\hline $\begin{array}{l}\text { Recognise the extent of knowledge gaps and act upon } \\
\text { uncertainties by taking precautionary measures. } \\
\text { Scientists should communicate these uncertainties in } \\
\text { their advice to policy makers. }\end{array}$ & $\begin{array}{l}\text { Knowledge gaps are filled with more scientific } \\
\text { knowledge and clear communication of the scientific } \\
\text { facts and uncertainties. Questions of precaution are } \\
\text { a political matter, not a scientific one. }\end{array}$ \\
\hline
\end{tabular}

I found that scientists often bore the brunt of the societal actors' frustration with a lack of influence on the course of the Kennisplatform. Because science was under discussion in the Klankbordgroep, scientists seemed the obvious choice of discussant with societal actors. Yet, I argue that a pure discussion of science, as the Kennisplatform seemed to want it, was impossible. Discussing science equalled discussing the moral and political implications of scientific knowledge. Most of the scientists did not deal with these underlying issues, and thus deflected any criticism with a reference to the scientific values of their studies. This, however, only widened the gap between 
what societal actors wanted (policy changes) and what scientists could offer (more extensive scientific knowledge).

Discussing science thus did not automatically lead to an agreement on the best scientific practices, the best ways to interpret science and the best ways to act upon science. STS scholars have argued that a better understanding of the scientific facts and different viewpoints on science often reinforces value disputes and competing interests. Such polarisation could result from the disagreement about the values that are inherent in scientific deliberations. In the Klankbordgroep, the problem was not so much that the opposing positions on the existence of health risks became more entrenched throughout the discussions, but that the Kennisplatform did not address fundamental ethical and political issues that came up during the debates.

\section{Challenging and maintaining the boundaries between science and politics}

All three aspects of science - performing, interpreting and acting on science - were topics of discussion in the Klankbordgroep. The discussions about the best practices of scientific research led to some significant changes in doing science. Societal actors were able to put their stamp on the ZonMw programme on EMF and Health. Scientists involved in this programme were very willing to accommodate some of the societal actors' views. New and on-going ZonMw research projects tried to involve the experiential knowledge of individuals claiming to suffer from EHS. In 2011, because of the on-going discussions on EHS in the Klankbordgroep, ZonMw issued a call for research proposals on 'a diagnostic tool for electrosensitivity', in which Stichting EHS was involved. This research seemed to be an example of what Nowotny and colleagues call 'socially robust knowledge production' (Nowotny et al., 2001): society was involved in the creation of scientific knowledge since the idea for the research came from societal organisations and non-scientists were involved in the research project. Yet, this outcome also further reinforced the assumption that more and better (in this case, socially robust) science was the best solution to deal with possible health risks from wireless communication technology.

In discussing science - and especially the interpretation and implications of science - societal actors also called for policy changes beyond performing scientific research. The Kennisplatform, however, did not act upon the discussions about the interpretation and policy implications of scientific knowledge. It argued that it was not part of its mandate. These issues, however, continued to polarise the positions in the Klankbordgroep. The discussions on the precautionary principle particularly showed how the Kennisplatform evaded dealing with ethical and political issues. From the first meeting in spring 2008 (Kennisplatform Elektromagnetische Velden en Gezondheid, 2008b), the Nationaal Platform Stralingsrisico's (NPS, see Table 5.1.) called attention to precautionary measures that were proposed in a publication called the BioInitiative Report (Carpenter and Sage, 2007). A group of scientists, researchers and 
public health professionals published the Bio-Initiative Report, and called for precautionary measures and lowering of exposure guidelines based on their review of the scientific literature on possible health effects from RF EMF. The Dutch government asked the Gezondheidsraad to review the report, as it "play[ed] an increasingly prominent role in the debate on electromagnetic fields and health" (Gezondheidsraad, 2008: 1). It concluded that the Bio-Initiative Report was "not an objective and balanced reflection of the current state of scientific knowledge. Therefore, the report does not provide any grounds for revising the current views as to the risks of exposure to electromagnetic fields" (Gezondheidsraad, 2008: 4). The Kennisplatform also wrote a Kennisbericht (Knowledge Note) that had the same reasoning: the report was not a balanced evaluation of the available scientific knowledge. It also added, "it is a political and not a scientific assessment whether the exposure limits should be changed and whether that involves the application of the precautionary principle. It is not the task of the Kennisplatform to make such a pronouncement" (Kennisplatform Elektromagnetische Velden en Gezondheid, 2008a: 3). ${ }^{38}$ The Kennisplatform drew a line between the political and scientific realm, positioning itself in the latter.

This boundary work did not withhold societal groups from wanting to talk about precaution and changes in policy more generally in the Klankbordgroep. During the second Klankbordgroep meeting, the NPS referred again to the Bio-Initiative Report and incited a debate on precaution. The NPS explained that this report asked a different question compared to the Gezondheidsraad or the WHO, that is, 'is there enough evidence for harmful health effects to take measures to reduce the risks?'. The Gezondheidsraad asked the question 'are harmful health effects proven?', and answered it in the negative, the NPS continued. StopUMTS agreed that the report should not be criticised because of a few imperfections and weaknesses but that one should look at the sum of all the indications of health effects which led to the conclusion that "it is high time that something is done in the Netherlands" (Kennisplatform Elektromagnetische Velden en Gezondheid, 2009a: 31). The discussion in the Klankbordgroep then focused on how much evidence was needed to take action. The chairperson pointed out that precaution was the government's task and was not in the hands of the Kennisplatform. StopUMTS reacted that this political choice was made based on information that the Kennisplatform and Gezondheidsraad supplied to the government. The chairperson of the ZonMw programme commission deemed it important that when there is a lack of science, better and new research should be done. He argued that the question about precaution was not a scientific question, but a societal question that needed political deliberation. Yet, these deliberations could be based on science, he added. A scientist from the TU Delft who was present in the audience,

\footnotetext{
${ }^{38}$ The European Parliament, on the other hand, embraced the Bio-Initiative study (European Parliament, 2008).
} 
replied that when one is dealing with societal risks, one should more often take into account the percentages of false negatives in the decision-making process (Ibid.).

Throughout the existence of the Klankbordgroep, members continued to use any opportunity to voice their opinion on the need for policy measures, often condensed in the language of precaution. This regularly happened, for example, when scientists from the ZonMw programme on EMF and Health presented their research in the Klankbordgroep. A discussion on the scientific details of a study would then turn into the meaning of the study for 'everyday life', as in, for those people suffering from EHS for example. In one case, the scientist in question answered that it was a political issue whether one takes vulnerable groups in society into account (Kennisplatform Elektromagnetische Velden en Gezondheid, 2009b). Whenever the discussion turned in the direction of implications of science for policy, scientists, ZonMw representatives and the Kennisplatform would emphasise the importance of more research, of bettertailored research questions, and of better communication, but there would be no talk of policy changes. Whenever the Stichting EHS demanded not only the recognition of EHS but also the establishment of treatments and so-called white areas where EHS patients can get away from all EMF sources, the chairperson of the ZonMw programme would answer that more research into EHS was important and that ZonMw welcomed research proposals on this topic (Kennisplatform Elektromagnetische Velden en Gezondheid, 2008b).

In the Klankbordgroep discussions, the Kennisplatform positioned itself as a scientific organisation that was separate from politics. Societal actors criticised the lack of a link between the platform and politics: "you are in the club, and people talk to you, they listen to you politely, but influence? Nil" (Interview K4). They called the Klankbordgroep a "lightning rod" that "has to grind the sharp edges from the dispute" (Interview K3). The platform countered this critique by arguing that the responsible ministries received the agenda and reports of the meetings, and that representatives were always present (see for example Kennisplatform Elektromagnetische Velden en Gezondheid, 2013: 6). These representatives, however, hardly ever spoke during meetings. I conclude that, even though the Klankbordgroep discussed science, only the discussion about one aspect of science - the best type of scientific research - had produced concrete results. Other issues that the discussion about 'science' had raised were duly debated, but did not lead to any important changes. Throughout the years, the Klankbordgroep paid attention to issues of uncertainty (how to deal with uncertainty, how best to communicate uncertainty), precaution, and the protection of vulnerable groups in society. Another topic that was regularly on the agenda was the perceived need to help those claiming to suffer from EHS. Despite the valuable insights these discussions produced, the Kennisplatform had problems translating these insights into policy actions.

Without a clear link between the Klankbordgroep discussions and politics, and without a clear communication strategy beyond targeting citizens via intermediaries, 
it might seem surprising that the Dutch government was enthusiastic and positive about the Kennisplatform, as was shown by the recent initiation of two other Kennisplatformen, around wind energy and cattle breeding. Most of the interviewees I talked to about the Klankbordgroep were positive about the exchange of knowledge and the respect for the diverging opinions that grew significantly since the early days of the Klankbordgroep. It became common, for example, to switch off mobile phones completely during meetings out of respect for those electrohypersensitives that were present. Those that were initially very critical of the existence of health risks from mobile telephony gradually became more comfortable talking about EHS and electrohypersensitives without always using the disclaimer that it was not a scientifically proven illness, such as 'complaints people attribute to EMF' or 'presumed EHS'. The growing recognition of EHS as a serious health problem in the Klankbordgroep gave the idea that this issue was what 'society' was most concerned about when it came to wireless communication technology. Society was concerned about health risks from RF EMF, and even more specifically, about EHS. Other Klankbordgroep members, such as the representative of the mobile phone operators, complained that the narrow focus on health risks was not representative of the societal situation. In his view:

[t]hose health aspects (...) are just a small part of a bigger thing. Because there is not so much protest in the country. And only a small part is about health. We should not magnify it as if it is in fact a societal problem. But it does look like it is a societal problem in the Klankbordgroep. If I talk to people in the streets, they have no clue (Interview K8).

Recently, also the Kennisplatform tried to move the discussion to other issues besides EHS, such as children and mobile telephony, in particular issues of cyberbullying, addiction to social media, safety online and concentration problems (Kennisplatform Elektromagnetische Velden en Gezondheid, 2013).

Summing up, even though the Klankbordgroep had the potential to become an interesting arrangement to deal with societal debates about new technologies, it nevertheless reinforced the focus on health risks and on scientific knowledge as the best way to deal with the issue. 'Society' was represented by a small group of actors who were convinced of possible health risks from the technology but who did not represent engaged citizens or any other societal publics who wanted to engage in mast siting decisions. The inclusion of a wider range of evidence and the engagement with a larger set of stakeholders and scientific disciplines turned out to be a major challenge to expert procedures on which the rationale of the Kennisplatform was based (see the second column of table 5.2.). It seemed unable to consider the broader issues that were about science, but could not be solved by science. It maintained a strict boundary between its own work, which it positioned as only concerned with assessing and communicating science, and politics, from which it distanced itself. As a 
result, the Kennisplatform mainly focused on executing the Dutch government's communication strategy of offering "realistic" information.

\section{The misguided belief in information as a solution to mast siting controversies}

The Antennebureau and the Kennisplatform were both means to the government's aim of better communicating its antenna policy and the science around EMF health risks. These initiatives were a direct reaction to mast siting controversies and more generally, to the assumed public deficit of understanding of EMF science. The government assumed that publics lacked scientific information and were misinformed by grassroots support teams. Moreover, it assumed that there were only certain types of publics that were interested in this information, i.e. citizens who had a personal interest in EMF science and those who were confronted with the siting of a base station in their neighbourhood. Communication to citizens thus went indirectly, via intermediaries such as municipalities and GGD'en. Also in the Klankbordgroep, the perspective of 'society' was restricted to the viewpoints of those societal actors that were convinced of the harmful health effects of RF EMF. The concerns of citizens engaged in local mast siting were left out of consideration. All of these assumptions about communicating EMF science reinforced the risk framing of the societal problem of wireless communication technology. The actual societal problems of mast siting, that I analysed in chapter 3, moved to the background.

My analysis of mast siting controversies showed that the government's assumptions about the public understanding of science were misguided. Most of the societal actors that the government's communication strategy targeted did not lack knowledge on wireless communication technology (see chapter 3). Engaged citizens were well equipped to gather information about the technical, legal and scientific aspects of mast siting long before they received information from government sources. In fact, most citizens, in particular the early engagers, were more knowledgeable than the intermediaries they came in contact with. The information citizens found online was assimilated in a landscape of knowledge and experiences of these citizens (see chapter 3 ). Citizens did not only make sense of science through evaluating the contents of the knowledge, also the context in which the knowledge was generated, its purpose and the normative assumptions embedded in the knowledge were evaluated. The government's conceptions of what kind of knowledge citizens lacked did not strike with the needs for information that citizens actually had. Moreover, the government's belief that better communication of science would lead to acceptance of base station siting ignored the fact that concerns about health risks were just one reason for citizens to engage (see chapter 3). These aspects, however, remained unacknowledged in the information provision context of the government's communication scheme. 
During the 2000s, as the public debate about health risks from base stations progressed, grassroots support teams tried to convince engaged citizens of the presumed flaws in the government's opinion about EMF science. Yet, grassroots support teams and citizens did not want the same thing. The government assumed that grassroots support teams represented engaged citizens in the Klankbordgroep, but I argue that there is an important difference. The strategy of grassroots support teams was twofold: recognition of the existence of health impacts from wireless communication technology and the implementation of policy measures that reduce exposure to RF EMF in society. Engaged citizens, on the other hand, were interested in gaining influence on the local siting situation. They did not want to reduce exposure in society, but were concerned about the uncertain nature of health risks and wanted to get the guarantee that a thorough decision had been taken on the local siting. More reassuring communication about health risks by the Antennebureau did not meet these citizens' needs (see chapter 4). Nor did their supposed representation by grassroots support groups in a knowledge platform reflect their concerns. Engaged citizens wanted to discuss the specific siting of base stations in their neighbourhood.

\section{Conclusion}

Throughout the 2000s, the Dutch government reacted to the increasing public dissatisfaction with the siting of base stations by tackling two deficits: a deficit of scientific knowledge and a deficit of communication of that knowledge. The government's focus in dealing with siting controversies lay predominantly with possible health effects of exposure to RF EMF. By resorting to a technocratic policy approach, the government relied on the image of science as a source of public and political authority. It used science as an arbiter in deciding about the legitimacy of the siting of base stations. Yet, the resort to science made things worse because it led to a shift in the public discussion from a mix of arguments against siting (choice of location, mismanagement local authorities, landscape pollution, need for technology) to a polarised debate about the existence of health risks. Science became judged in different ways: societal actors, especially grassroots support teams, criticised the content of scientific knowledge and the interpretation by scientists and science advisory bodies, and called for attention to the social implications of scientific knowledge. The government reacted to the growing societal discussion by investing in risk communication. Its communication strategies, including the initiative of the Klankbordgroep, started from the conviction that health risks were at the heart of the societal debate about mast siting and mobile telephony. It thus reasoned from a deficit model of public understanding: citizens were ignorant about the scientific facts and would stop being concerned once they received the right information. I argued that this was not a case of misunderstanding science: citizens were not the laypersons that the government took them to be. Moreover, the societal groups that were supposed to represent society in the 
Klankbordgroep further entrenched the focus on health risks as the main societal concern. I argued that societal concerns were much broader than a concern about health and that discussing science in the Klankbordgroep led to a polarisation between those who believed in health risks and those who did not.

I conclude this chapter by summarising what the analysis of the risk-based governance strategy of the Dutch government means in terms of understanding the dynamics of the wireless communication technology controversy. Firstly, by investing in risk research and communication, the government further framed the societal issues around the siting of the technology as health issues. This reasoning justified the investment in science as the only legitimate answer to the societal controversy. Science, however, was not able to make a judgement about the legitimacy of mast siting. This led to a discussion about science that continues to this day. It is very unlikely that more scientific knowledge will ever provide the conclusive answer that wireless communication is or is not a health risk. The goal of finding the answers in science is further hampered by the fact that research can only address yesterday's technology (see e.g. von Gleich, 1999). Secondly, the risk-based governance approach legitimated the position of those actors who also relied on scientific knowledge. During the episode of the TNO and Swiss study, for example, many municipalities used scientific arguments to postpone making a policy decision on mast sitings. Engaged citizens also invested in understanding EMF science to use it in their notices of objections or court cases. Especially those citizens who went to court were convinced that an in-depth analysis of particular scientific studies would be a convincing argument. It also explains why the Kennisplatform only invited those societal actors who had become convinced of detrimental health effects of RF EMF and could be considered 'experts' on EMF science. Thirdly, the risk-based policy approach turned out to be an intensive, yet unsuccessful policy strategy that did not have any relationship with the concerns of citizens about mast siting. Concerned citizens, however, were the main reason for the risk-based policy approach of the government. Along the way, the initial reasons for citizen engagement with mast siting were lost out of sight. Mast siting controversies are not solved by investing in more science and communication. As I have argued in this thesis, citizens wanted to engage with mast siting because they wanted the government to prudently deal with a new technology for which there were scientific uncertainties. The government never considered discussing the best ways to site base stations, taking into account these societal concerns about precaution. Instead, it asked science to answer a different question: are there health risks from exposure to RF EMF? 

CHAPTER 6

Conclusion 


\section{Engaging with siting controversies}

The siting of infrastructures for old and new technologies is a never-ending story: the more people, the more infrastructure for waste management, energy production (wind energy, hydraulic fracturing, electricity, nuclear energy, etc.), industrial activities and communication technologies (radio, wireless communication, etc.) are needed. Citizens who are confronted with the siting of an infrastructure in their neighbourhood may not agree with the policy decisions and engage. Politicians, policy makers, and social scientists usually find these reactions difficult to understand, especially when it comes to technologies that show a high public demand or approval, such as masts for mobile telephony or windmills. Siting controversies are therefore generally understood as disruptive, unpleasant, challenging and delaying progress. Concepts such as Not In My Backyard (NIMBY) have contributed to the image of citizens as opposing policy decisions because of irrational and emotional concerns. Especially when there are concerns about possible health risks, for which there is no scientific evidence, citizens' concerns are cast away as 'risk perceptions' that do not concur with the experts' views.

In this dissertation, I have traced the societal dynamics of one type of siting controversies: the siting of mobile phone masts in the Netherlands and Flanders (Belgium). At the centre of these mast siting controversies have been collectives of citizens engaging with the siting of base stations, networks of organised groups supporting citizens in their engagement, municipalities threading a minefield of conflicting interests, national policymakers and mobile phone operators trying to solve the deadlocks that arose over the siting controversies, and scientists infusing their knowledge into policy. I have asked how we can understand the societal dynamics and mechanisms that account for the emergence, sustainment and possible ending of mast siting controversies? One type of dynamic I was particularly interested in was the role of scientific knowledge and uncertainties: how do different actors in the controversy (citizens, policy bodies, scientists) use, construct, contest or ignore scientific knowledge regarding wireless communication technology? I started my research from the observation that health risks were a dominant theme in discussions on the technology, and especially on siting. Why and how did wireless communication technology become a serious 'health risk'? I explored the dynamics between engaged citizens, different levels of decision making, scientific knowledge about health risks from radiofrequency electromagnetic fields (RF EMF) and attempts at deliberation.

In this concluding chapter, I go back to my research questions and describe the insights that my research generated about the societal dynamics of emerging technologies and of mast siting in particular. I argue that the emergence, sustainment and ending of mast siting controversies has to be understood as a dynamic interplay between citizen engagement around mast siting and governance approaches to this engagement. The interaction between different levels of administration accounted for 
the dominant focus and entrenchment of health risks. Referring to health risks became 1) a politicised argument by citizens (the state should protect its citizens from harm), 2) an explanatory factor for mast siting controversies used by the national government (citizen engagement arises because of fear of radiation), and 3) the driving force of a particular policy mode (a risk-based approach). I will explain and empirically substantiate these findings in more detail in the next sections. I begin by discussing the different patterns that typify citizen engagement. In the next section, I discuss the risk-based policy approach of the Dutch government as response to this citizen engagement. In the third section of this chapter, I recapitulate the different dynamics that explain why the siting of base stations for wireless communication technology became a serious policy problem. I argue that these dynamics can explain the rise of controversies around other (emerging) technologies. I end by emphasising the need for acknowledging and reconceptualising the democratic role of citizens in siting controversies.

\section{The dynamics of citizen engagement}

\section{The collective and local character of engagement}

I typified the individuals engaging around the siting of a base station as collectives of engaged citizens who tried to change a local decision they disagreed with (see chapter 3). Engaged citizens were not anti-technology, but they were against the siting of a mast on a particular location in their neighbourhood. Citizen engagement with mast siting started when alert citizens discovered that a mast was going to be sited or when they discovered that construction works on a mast were going on. The official notifications of exemption decisions (ontheffingsbesluit) and building permits (bouwvergunning) often went unnoticed, and a large number of citizens heard the siting news through informal networks and the local media. In any case, a vigilant person was needed to spot the announcement and to spread the news in order for the engagement to begin. In all cases, these alert persons - or early engagers as I called them fitted a certain profile: 1) they were higher educated, 2) more than average interested in political decision making and 3) well-embedded in local networks (such as a local business owner, member of a residence associations or reporter for the local newspaper).

Even though early engagers were already convinced that the planned siting was a negative development, they put considerable effort into exploring whether the neighbourhood wanted to act with them. My research demonstrated that the support of neighbours was a precondition for further engagement: if support was secured, the mast changed from an individual concern to a local issue that deserved the attention of the whole neighbourhood. Once the siting of a mast had become a shared concern, the commitment deepened. In most cases, citizens established a group of neighbours. 
The early engagers, usually not more than three people, were the most active members of this group and started to build a dossier with technical, legal, political and health-related information. Yet, in all case studies, they considered it necessary to inform the neighbourhood regularly, to ensure the continued support. These groups thus shared a lot of the characteristics of what the environmental and social movement literature calls 'grassroots groups' (Tesh, 2000): they were tied to a neighbourhood, informal, open, temporary and flexible.

After the support of neighbours was secured and a grassroots group was established, engaged citizens set to work to make a plan to get involved in the siting decision. My case study research showed that most groups of engaged citizens drafted an official complaint for the municipality: a notice of objection (bezwaarschrift, Belgium) or a submission of their viewpoints (zienswijze, the Netherlands). This shows that citizen engagement was agonistic (Mouffe, 2005): citizens questioned the policymaking decisions around mast siting, but did this within the boundaries of a political system. They perceived the mobilisation of different viewpoints on siting as a form of active responsibility. Engaged citizens incorporated a wide range of arguments in these complaints, representing the diverse views of the group of neighbours. Yet, often the emphasis of the complaints was put on those arguments that the early engagers found most important and that usually also represented the 'culture' of the neighbourhood (compare Gibson, 2006), i.e. the values, practices and norms that attributed to a certain identity of a neighbourhood. Young neighbourhoods with children mostly focused on the possibility of health risks and neighbourhoods close to or in the countryside focused on the landscape pollution of the mast.

I argued that citizen engagements are forms of bottom-up social initiatives that fit into a new vision on politics and society. Scholars assert that traditional forms of political engagement are in decline, but citizens get involved in politics on their own accord, without the top-down invitation of the government (Rosanvallon, 2008; Verhoeven, 2009; WRR, 2012). Citizen engagement in mast siting controversies can thus be understood as such a counter-democratic practice (Rosanvallon, 2008), even though the idea of 'counter' seems to be at odds with Rosanvallon's meaning of the term: he refers to the rising societal demands for participation, involvement and transparency. The engaged citizens I met in my research demanded an opportunity to voice their constructive criticism, to be taken seriously, and to have a say in an important local decision. Engaged citizens strove to achieve, in more or lesser degree, what Arendt (1963; also see Leighninger, 2006) called 'public happiness': the feeling of participating in politics, of being part of an invaluable experience.

\section{Dependence on networks}

Next to the collective and local character of citizen engagement, my research also showed the importance of networks for citizen engagement. Neighbours, friends and 
family living in the vicinity were the closest source of support. Engaged citizens also turned to local politicians, the municipality and journalists to further the engagement. In their quest for information about masts on the Internet, engaged citizens encountered what I call the 'grassroots support teams' whose purpose was to inform citizens about negative health effects from exposure to EMF. These websites of grassroots support teams turned out to be crucial for the engagement in all of my cases (see chapter 3 and 5). The contact with the grassroots support teams online had several impacts on collectives of engaged citizens: it served as an acknowledgement of their cause, it informed citizens about possible detrimental health effects from masts, it proposed a particular set of social actions, and it exposed an overall mismanagement of mast siting by government and industry. The grassroots support teams supported local citizen engagements, but also operated on regional, national and even international levels.

The grassroots support teams were eager to convince engaged citizens that RF EMF emitted by antennas is a serious health concern. However, the extent to which the argument of health effects of masts made sense and was picked up by citizens, depended on the resonance of it with the culture of the neighbourhood and citizens' own experiences, knowledge and commitments. I have argued that citizens were embedded in a diverse and shifting landscape of knowledge and experience (chapter 3). They thus relied on opinions of others (personal or institutional, friends or other organisations) and on individual or collective experiences in order to make a judgment about the harmfulness of the mast. These experiences could relate to health risks (such as knowing a person who claims to be electrohypersensitive), but also to the local political situation. Citizens' perspectives of mast siting were thus shaped by what is known in the literature on public understanding of science as 'processes of reflexivity' (Lash and Wynne, 1992; Wyatt and Henwood, 2006) that extend far beyond a simple right or wrong understanding of the risks associated with the technology.

The argument of possible health risks often played a role in mast siting controversies, but citizens put the argument in the context of a mismanagement of siting practices, with the local government as the main culprit. Unlike the grassroots support teams who wanted to end the siting of all masts in the entire country (and even beyond), engaged citizens argued that the siting on that particular spot in their neighbourhood was a bad decision. The grassroots support teams argued in a 'definite risk frame', i.e. there are health risks. Engaged citizens pointed to an 'unknown risk frame', i.e. there are too many uncertainties in the scientific knowledge to rule out the possibility of risk. Both frames call for different policy actions: the former calls for the restriction of the technology and the acknowledgement of health risks; the latter calls for a thorough local planning decision on whether and where to site a mast. 


\section{The appeal of health risk framing}

Neither the national government, nor many social scientists studying the issue acknowledged this difference. In chapter 2, I reviewed the existing social science literature on mast siting controversies and wireless communication technology. This showed an overall focus within academia, especially within risk studies, on citizens' understandings or perceptions of health risks associated with the technology. The conclusions of these studies often pointed to a need for better communication of the risks. I criticised these studies for having limited value to understanding siting controversies. Firstly, they portray citizens as individuals with predetermined or unchangeable ideas about the technology, whilst citizens acted as collectives in siting controversies and made sense of the technology through landscapes of knowledge and experience (chapter 3). Secondly, these studies start from the unsubstantiated assumption that citizens were afraid of the radiation from base stations and for that reason, were not willing to allow the siting of one in their neighbourhood. This supposes that the controversy was best understood as a 'risk-issue', and thus as a problem of (misunderstood) scientific knowledge.

However, my analysis of the case studies (chapter 3), and the representative analysis of Dutch municipalities (chapter 1 ) showed that mast siting controversies arose for divergent reasons. The controversies cannot simply be labelled as 'risk issues'. I divided the concerns into five categories: concerns about 1) possible health risks, 2) lack of involvement in the decision-making process, 3) landscape pollution, 4) devaluation of property prices and 5) impact on flora and fauna (see Figure 1.3. in chapter 1 ). In many cases, however, citizens voiced a combination of arguments. If one argument prevailed, it was mostly related to health concerns or concerns about landscape pollution. The interviews with engaged citizens in the different mast siting controversies also showed a profound resentment towards the municipality: citizens accused the municipality that it did not properly manage the siting process and looked after the mobile phone operator's interests instead of its citizens.

Despite the multitude of arguments against the siting of base stations that citizens put forward in mast siting controversies, the argument about health risks was a theme in all of my cases. My research showed that citizens considered the risk framing a rather convincing and successful frame (chapter 3 ). It seemed to strike a sympathetic chord: unlike arguments about lowering of housing prices, landscape pollution or more or less personal grudges against the municipality, the idea that neighbours' health should be protected was an argument that was hard not to sympathise with. Moreover, portraying the siting of masts as an infringement on people's health had the discursive power to create a collective belief that there was a problem and that action was needed to solve this problem. The argument of health risks also made sense to engaged citizens because it fitted with other, non-scientific sources of understanding people had, such as personal (embodied) and collective experiences of ill- 
nesses attributed to RF EMF exposure. It resonated and activated shared beliefs and values: taking care of one's health and the health of one's family (especially young ones) was considered to be of paramount importance. In addition, citizens were familiar with other forms of environmental exposures, whose (possible) harmfulness strengthened the belief in the negative health effects from RF EMF. Ionising radiation is known to negatively affect health, but also the possibilities of harmfulness of low frequency electromagnetic fields from power lines, as well as microwaves from radar, ovens and other applications have been duly debated in the past and present.

Citizens engaged with the health risk framing of the issue - i.e. as a problem of unknown health effects from exposure to RF EMF - because it strengthened their cause. They used the language of risk as a political instrument that gave them the power to demand policy changes. They considered it an argument that could not be neglected by (local) governments, politicians and media. Yet, the national government's approach to mast siting did not match with the expectations and views of citizens. Moreover, the resort to health risks turned out to be a blind alley in the Netherlands, in contrast to my cases in Flanders. In the next section, I discuss the riskbased approach to mast siting with the aim of showing the discrepancy between engaged citizens' and the national government's perspectives on mast siting.

\section{Governance approach to mast siting}

\section{Disqualifying citizen engagement}

In chapter 4 and 5, I discussed the developments and implications of the Dutch government's policy on wireless communication technology and mast siting. After the sale of GSM- and UMTS-frequencies (o.a. extended GSM in 1998 and UMTS in 2000) to mobile phone operators, the Dutch national government was concerned with safeguarding the swift rollout of a wireless communication network. When citizens and municipalities started to question the siting of base stations, the government (and the mobile phone operators) classified these developments as sources of possible delays to the progress of the formation of a network. The government questioned neither the need for such a network, nor the urgency of its establishment. From such a starting point, the government understood citizen engagement as a form of protest or resistance to a technology that it believed to be in the nation's best interest. The government's national antenna policy (2000) had to secure the formation of a network and ensure the ending of the controversies. It wanted to achieve these goals by changing the regulation on siting: antennas up to 5 metres could be sited without a building permit and constructions up to 40 metres needed a light building permit from the municipality.

The national antenna policy curtailed the local government's means to have a significant vote on whether and where siting would occur. Municipalities could deny 
the siting of masts based on a conflict with the local zoning plan, but the Dutch antenna policy prescribed that concerns about health risks were not a legitimate reason to refuse the siting of a base station. If the operation of the antennas did not violate the exposure limits that the government implemented, such operation had to be considered safe for public health. The decision on the locations for siting was left entirely to the mobile phone operators who approached municipalities whenever they needed to build a mast. These policy decisions put municipalities in a difficult position: they were the first contact point for engaged citizens with questions and concerns about siting, because citizens considered the municipality to be the authority in charge. Yet, municipalities had very few legal means with which to negotiate the siting of base stations on their territory. My analysis showed that the decision-making process emphasised the national interests and not the local level. Municipalities had no formal room for local involvement in base station siting, only an administrative, bureaucratic role.

I characterised the decision-making process around mast siting as a narrow debate about the chances and risks of wireless communication technology (chapter 4 and 5). The government enforced national policy, thereby passing over local policy and ignoring the societal debate that had started after the first base stations were sited. The antenna policy had major consequences for citizen engagements. The national government disqualified the legitimacy of citizens as stakeholders in siting decisions by limiting the municipalities' power in choosing the location of base stations and thus denying a local democratic decision-making process. The government did not see citizen engagement as forms of spontaneous participation in local politics, but dismissed citizen involvement as unfounded concerns about health risks. In political discussions on the antenna policy, citizens were portrayed either as consumers of a much-needed technology or as ignorant protesters against the necessity of the development of wireless communication technology. Concerns about health thus became the government's explanation for mast siting controversies. This understanding of mast siting controversies also became the driving force of a risk-based policy approach.

\section{Risk-based policy approach}

Another strategy of the government to deal with mast siting controversies was the removal of the issue from the policy domain to that of scientific expertise. It transformed the issue from a political question with many uncertainties to a narrow scientific question for which expert advice was deemed indispensable. The national government's risk-based regulatory approach was rooted in 1) the denial of the legitimacy of citizen engagement in mast siting practices; 2 ) the understanding of mast siting controversies as the outcome of unfounded fears for health risks from the antennas; and 3 ) the assumption that mast siting controversies could be dissolved by investing in scientific knowledge about health risks and risk communication. A risk-based ap- 
proach thus became the government's policy for understanding and dealing with siting controversies. It offered an explanation for the controversies, i.e. the public misunderstands the risks, and offered solutions, i.e. invest in more research and explain risks more clearly. I recapitulate my analyis of the previous chapters by looking at the 1) deficit of scientific knowledge about possible health risks from antennas, 2) deficit of communication of this scientific knowledge and 3) the most recent government initiative in dealing with mast siting controversies: the participation of 'society' in a sounding board.

\section{Risk science: from judge to being judged}

The government used science as scientism (Welsh and Wynne, 2013; Wynne, 2010) or as an arbiter or judge, as I called it (see chapter 5). Scientism is the engrained assumption that scientific evidence is the only authority that can justify policy action. Scientific knowledge had to decide whether the rollout of a wireless communication network was legitimate or not. I showed that even though framing a societal issue in terms of 'risk' might seem to depoliticise the debate because of the presumed impartiality and authority of science as the unchallengeable source of knowledge, it in fact made the controversy worse because science became the battlefield to argue for or against siting. I argued that regulatory science could never provide policy answers, even if it was asked to. The government left the necessary policy interpretation of scientific studies to its scientific advisory body the Gezondheidsraad, who drew a boundary between what was an acceptable and unacceptable risk. Societal actors, however, disputed the Gezondheidsraad's judgement. The risk-based policy approach led to a shift in the public debate on siting from a diverse discussion about the desirability of base stations and the spatial planning aspects of base station siting to a polarised debate about the existence of health risks. Critics of the government's policy contested the scientific interpretations, accused scientific advisory bodies and institutes of partiality and highlighted uncertainties in the scientific knowledge. They exposed the inherent values that were embedded in regulatory science and drew attention to such value-laden questions as 'How to deal with disagreements among experts?', 'What to do with uncertainties in scientific knowledge?' and 'Who is responsible for the possibilities of nasty surprises from the technology?'. Because of the riskbased policy approach, the issue of base station siting became scientised. An outcome of this scientisation was that science itself - and scientists - went from judge(s) to being judged themselves. Because science-informed arguments became central, public actors such as grassroots support teams also shifted their attention from the local to the national decision-making level as the arena where they hoped to be able to influence policy.

The risk-based policy approach thus had the effect of relabeling the issue of mast siting from a spatial planning question to a scientific question about health risks. As I 
have argued throughout this thesis, the public discussions about mast siting involved questions about risk, but it was not purely a scientific problem. The problem was extracted from its local context and the actual local concerns that mast siting had triggered were lost out of sight. The government portrayed science as an ultimate judge, ascribed with the power to evaluate whether the rollout of the technology was legitimate or not. The belief that siting controversies were about health risks, and thus science, became deeply entrenched. So much so, that there was no possibility for other policy solutions anymore.

\section{Risk communication: reinforcing the deficit model}

A second aspect of the government's risk-based approach was the development of stronger communication programmes. The communication programmes were developed from two assumptions: 1) only a limited part of the public was in need of information, i.e. citizens who were confronted with the siting of a base station and those who asked questions to intermediaries such as the municipalities, GGD'en (Community Health Services) and mobile phone operators and 2) those publics lacked scientific information about health risks and were misinformed by untrustworthy information from the Internet. I argued that the second rationale is known as the 'deficit model of public understanding of science' and has been discredited by social scientists for years, but is still a strongly held belief in risk management (Irwin and Wynne, 1996; Short and Rosa, 2004; Sturgis and Allum, 2004). Since municipalities were perceived as important intermediaries or even spokespersons between the national government and citizens, the government expected that the availability of more and bettertailored communication to municipalities would lead to less siting controversies.

In the early 2000s, the government established the Nationaal Antennebureau to help municipalities to deal with local concerns about mast siting (chapter 3 and 4). Organising an information session during which the Antennebureau, local GGD and mobile phone operators explained the regulatory, technical and health aspects of base station siting was considered the preferable way by which municipalities could address citizen's concerns. These meetings were based on the assumption that more knowledge on mast siting, and especially on health effects, would appease existing siting controversies or prevent new ones. In chapter 4, however, I argued that the information sessions were not attuned to the political and societal needs around mast siting. It suppressed the possibility of citizen engagement with local politics and the possibility for local politics to play an accommodating role towards citizens. The information sessions provided generic information on the antenna policy, but citizens were interested in the local situation, i.e. they wanted to discuss the local siting, as I showed in chapter 3 . The sessions were not set up as deliberations, but focused on reassuring citizens that there was nothing to worry about in scientific terms. This unidirectional scientific information did not cater to the needs of the audience, who 
mostly consisted of collectives of engaged citizens who questioned the scientific studies presented and who pointed to scientific uncertainties.

I argued that the government's assumption about the public deficit in knowledge ignored three aspects of mast siting controversies that my analysis yielded. Firstly, public discussions of EMF were not just epistemic issues, but touched upon broader societal questions of technology innovation, spatial planning, citizen engagement in local politics and property rights (chapter 3). Secondly, the societal actors that the communication was targeted to, such as engaged citizens in mast siting controversies, were not deficient in knowledge, but usually gathered information on diverse aspects of base station siting prior to receiving the government's information and considered themselves more knowledgeable than municipal officials (chapter 3). Thirdly, citizens made sense of scientific information by fitting it into their landscape of knowledge and experience and by judging its content, context and purpose (chapter 3). It was thus not a case of misunderstanding science but a case of public disagreement with the implicit normative assumptions that using science as scientism implies.

The assumption that communication should only go through intermediaries diminished the role of municipalities to one of risk communicators. Municipalities, however, tried to influence the local siting policy in alternative ways, such as supporting citizen engagements, postponing the policy decision on mast siting until the national government provided more scientific clarity or starting a lawsuit against the mobile phone operator (chapter 5). From a risk management perspective (Löfstedt, 2005), the local support of the national policy by political actors is considered crucial for any policy to be successful, because citizens are not likely to trust a national policy decision if the municipality is critical of this decision. Better communication about the lack of health risks from wireless communication technology, however, did not involve local authorities in the antenna policy, but reduced them to spokespersons of a policy that many of them criticised.

\section{Participation of 'society': entrenching the health risk framing}

In 2007, the government's plan of communicating to citizens via intermediaries continued with the establishment of the Kennisplatform EMV \& Gezondheid (Knowledge Platform EMF \& Health, see chapter 5). The Kennisplatform gathered all the professional knowledge and expertise on EMF and health in the Netherlands in order to provide the latest information to intermediaries who stood in close contact with citizens. Even though all of this information was accessible via a website, the Kennisplatform did not put any efforts into publicising this information to a wider public audience. The idea remained that people who wanted information would also be able to find this information. The Kennisplatform claimed to listen to the 'voice of society' by entering into conversation with a particular public group who represented those that were convinced of harmful effects from RF EMF, i.e. grassroots support teams and 
interest groups for electrohypersensitives. This conversation took place in the Klankbordgroep (Sounding Group).

In chapter 5, I argued that the invitation of these actors reinforced the national government's understanding of, and dealing with, the societal problem of mast siting as a health risk issue and hence a scientific problem. The position of more radical grassroots support teams became foregrounded, while the concerns of local citizen collectives disappeared in the background. The discussions of scientific knowledge in the Klankbordgroep, however, did not lead to a mutual agreement on how to deal with EMF and health in society. Besides the growing respect for the different opinions and the start of a research project in which societal actors were involved, the Klankbordgroep primarily exposed the fundamental differences in opinion about the political nature of EMF science. I distinguished between three processes of science that were under discussion (compare Brown et al., 2006; see Table 5.2. in chapter 5): doing scientific research, interpreting scientific research and acting on science. The Kennisplatform encouraged discussions of the first aspect - doing scientific research between the grassroots supports teams and interest groups and ZonMw scientists. The grassroots supports teams and interest groups, however, also wanted to discuss the interpretation of scientific results, and the implications of these results. They demanded policy changes, but the Kennisplatform drew a sharp boundary between its scientific task of evaluating and communicating science, and politics. In recent years, the Klankbordgroep tried to focus on broader issues of EMF and health (beyond the narrow focus on electryhypersensitivity) and continued its efforts to provide clear communication to intermediaries.

I concluded that the Klankbordgroep had the potential to become a productive forum where diverse groups - experts, policy makers, health care professionals, societal organisation, and industry - could discuss wireless communication technology in society. Yet, from the start, the societal issue of wireless communication technology was framed as a scientific issue. The initiative of involving 'society' only arose at a point when the political and public debate about wireless communication technology had already indurated to a health risk question. The outcomes of these discussions thus also focused on science: involving particular societal groups, who represented people's concerns about health risks, in scientific research programmes and more clearly communicating the diverse views on science that came up during the discussions. For this reason, I argued that the Kennisplatform and Klankbordgroep were another dynamic in understanding why wireless communication technology became a serious health risk, even though the siting of base stations evoked a diverse range of reactions. It reinforced the deployment of scientific knowledge as scientism in public discussions on EMF. This led to the contradictory situation that health risks were dismissed as legitimate arguments on a local level (objections against base stations could not be made on the basis of health aspects), but were nevertheless debated on a national level by societal actors who supposedly represented 'society'. 
The health risk framing became central in the national discussions of mast siting. The diverse local concerns of municipalities and engaged citizens did not feature in these deliberations. The risk-based policy approach of the government, and especially the establishment of the Kennisplatform, removed engaged citizens and their concerns from the table. This, however, did not mean that these concerns ceased to exist: siting controversies continued to emerge until today. The gap between the local and national level widened throughout the years, as the national government entrenched the focus on health risks as the best way to deal with mast siting controversies. In this thesis, I argued that the local perspective on the governance problem of mast siting was one of incapacity to influence a local policy decision: local actors wanted to be involved in deciding where the mast would be sited. The national perspective on the governance problem of mast siting controversies, on the other hand, was one of deficits - of science and of communication. This mismatch between the local and national levels attributed to the continued emergence and sustainment of mast siting controversies.

Citizen engagement was mostly without concrete results. It ended either when the mast was sited or when a judge ruled in favour or against the siting. Deeply convinced of the harmfulness of RF EMF, the most ardent engaged citizens established groups that extended far beyond the localities of the neighbourhood and municipality (such as in Spijkenisse and Drongen). They wanted to change policy on national, European and international levels, which turned out to be policy arenas where one could actually discuss health risks. The issue then moved beyond the locality of the neighbourhood. Most engaged citizens, however, did not continue on this path. During the interviews I had with them (sometimes years later) about the engagement, they expressed their frustration and resentment at not having been able to influence local policy-making processes. Some could not understand how their goodwill to become engaged could have been so easily cast aside.

\section{The dynamics of controversies around technologies}

In chapter 1, I argued that my research on siting controversies fitted into a broader academic and policy debate about how society should deal with (emerging) technologies (Blankesteijn et al., 2014a; Boholm and Lofstedt, 2013; Callon et al., 2009; Hess and Coley, 2012; Jasanoff and Wynne, 1998; Ottinger, 2013b; Stilgoe et al., 2013; Verhoeven, 2009). My analysis of the interaction between society, science and policymaking in mast siting controversies adds to this growing body of literature. This thesis points to several dynamics and patterns that show the conditions under which controversies can arise over technological innovations. Some dynamics only relate to the local implementation of technologies, and others can also be witnessed in public and political debates about innovations that do not need to be sited. The discussion of 
these dynamics also shows how the issue of mast siting controversies could have been dealt with differently, in other words, how it could have been otherwise.

I first discuss three local dynamics that are important in understanding why the siting of a particular technology might become controversial:

The lack of public options to become involved in decisions about siting of the technology and/or the lack of choices about siting

The citizens that I encountered in my research, and several city councils, were disappointed and frustrated that they were not able to participate in the siting decision. I argued in this thesis that this lack of involvement was an incentive for citizens to start to engage. It is striking that in those cases where citizens could decide between different siting options, there was no controversy, such as in one of my case studies, Euverem, and in a few municipalities where neighbours could chose different locations that the mobile phone operator had picked out (see section Information sessions as crucial dynamic in siting controversies in chapter 4). Even though I do not have enough empirical evidence to fully support this hypothesis, I am inclined to state that more mast siting controversies might have been solved if citizens and municipalities would have been involved in the location choice. This fits with my consistent observation that citizens wanted to be taken seriously, and wanted to engage. If they felt that they were not, the engagement deepened.

The dynamics of the local community: the embeddedness of public concerns about siting in their neighbourhood culture and in a history of contestation about local or national issues (for example, previous disagreements about spatial planning or the experiences of national health scares)

It was a recurrent finding in my research that the local character of the neighbourhood largely influenced whether citizens started to engage, which arguments were used and what actions were undertaken. The decision-making process around mast siting, however, did not value or take into account the cultural, historical or social dimensions that shaped the main qualities of a neighbourhood. In those cases where citizens highly valued the protection of their landscape and urban surroundings, the siting of mast was seen as an invasion of this character. All of the mast siting controversies I investigated took place in neighbourhoods with a strong identity, which was particularly embodied by the early engagers. 
The enforcement of a national policy without taking local considerations into account and without acknowledging a decisive role for local authorities

The Dutch government's antenna policy negated the authority of local governments to influence the local siting processes. In order to encourage the rollout of wireless communication technology, the government decided that most base stations could be sited with only the permission of the building owner and without a building permit. Mobile phone operators only needed a building permit for the construction of masts: they chose the location to which municipalities could object only based on a conflict with the local zoning plan. This industry-supported policy strategy never questioned the need or the urgency of a nationwide network. The government even added to the urgency by legally enforcing all mobile phone operators to provide such a network in a few years. From such a position, mast siting controversies became perceived as even more problematic. My analysis showed that it would have made a lot of sense to question the limited role of local actors in the antenna policy: why could municipalities and citizens not have any rights to decide on base station siting? Moreover, the urge by which the government pushed for the expansion of a wireless communication network denied a broader discussion on the implementation of the technology. There was no debate possible about technical solutions to base station siting, such as investing in the development of alternative base stations (e.g. smaller or less visible in the surrounding) or obliging mobile phone operators to camouflage base stations (antennas and masts). Neither was there any thorough discussion about the perceived need for multiple mobile phone operators who all had to site base stations simultaneously, beyond the demand to 'site-share' (allowing the siting of antennas from other mobile phone operators on one mast).

Next, I also noticed several other dynamics that can be witnessed in more general public and political debates about technologies:

The exclusive framing by policymakers of public issues in scientific terms, even though the societal debate is multifaceted, with a diversity of interests and touches upon important themes in society

My analysis showed that the public discussion on wireless communication technology was complex, multi-layered, and was related to economics, the environment, health, community involvement, spatial planning and the social need for the technology. I argued that the public debate on wireless communication was much broader than just a question of health risks from antennas or mobile phones. The introduction of wireless communication technology had a major influence on the way people communi- 
cate with each other, and thus on the functioning of society. Especially around the time of the UMTS-generation in the mid-2000s, citizens involved in mast siting controversies worried about this social aspect of wireless communication technology. By now, this discussion has moved to the background because hardly anybody doubts the benefits of wireless communication technology anymore. Instead, other social problems related to the technology have emerged, such as privacy issues, addiction to mobile phones, cyber bullying and concentration problems due to intensive use of mobile phones and tablets. I argued that the risk-based policy approach of the government narrowed the broad discussion on the technology to a focus on 'EMF and health'. In the Klankbordgroep, this focus was further condensed to a discussion about possible health effects of RF EMF exposure, and especially electrohypersensitivity.

The existence of and easy access (through the Internet) to a strong counterexpertise network consisting of grassroots support teams and interest groups who politicise uncertainties and expose values embedded in scientific knowledge

The contact with grassroots support teams was a crucial aspect of citizen engagement. In some cases, this contact changed the focus of the engagement to an argument about health risks. The involvement of grassroots support teams in mast siting controversies and in the public debate on wireless communication technology also had another important effect on the dynamics of siting controversies: the national government equated societal concerns about mast siting with the arguments about health risks from these grassroots support teams. Consequently, when a deliberative platform was established that wanted to hear the opinion of 'society', i.e. the Klankbordgroep, these groups were invited as the representation of societal concerns about the technology. However, I argued that there were important differences between grassroots support teams and engaged citizens. The former wanted to convince the government of the harmfulness of health risks and were thus eager to engage in conversation with scientists about the question whether there are health risks from RF EMF. Engaged citizens, on the other hand, were not convinced of the harmfulness of RF EMF, but of the existence of uncertainties that warranted a prudent approach to siting base stations. They thus asked the question whether this was the best place to site base stations, in view of the precautionary approach.

The execution of a risk-based policy response that dismisses any health-related concerns and precautionary arguments by using scientific studies and scientific advisory bodies as arbiters who draw boundaries between what is an acceptable and unacceptable risk 
'Risk' became the dominant mode of explanation for the emergence of mast siting controversies and for its policy solutions. The central role of science in understanding and acting upon mast siting controversies performed a particular citizen who was not supposed to become involved in the siting practices but who needed to be educated about science. The government portrayed science as an ultimate judge, ascribed with the power to evaluate whether the rollout of the technology was legitimate or not. As I have argued throughout this thesis, the public discussions about mast siting involved questions about risk, but it was not purely a scientific problem.

\section{Concluding remarks: moving beyond risk}

My analysis has made apparent the negative consequences of dealing with a multifaceted societal issue only in terms of a risk-issue. It made siting controversies into a problem of science and communication, and a challenge that needed to be overcome, according to the government. My findings relate to an increasing academic interest in the use of a risk-based policy approach, as a presumed powerful and legitimate way of dealing with emerging technologies and siting controversies (Borraz, 2008; Hood et al., 2001; Jasanoff, 1999; Power, 2004; Rothstein et al., 2006, 2013; Stirling, 1998). The prevalence of contemporary risk discourses seems to lie in a paradox (Borraz, 2008). On the one hand, risk serves as a political instrument by which social problems gain access to the public agenda, i.e. it is a means of politicising new forms of vulnerability by calling onto the state for more protection and security. On the other hand, risk is a means of transforming governing practices, through recourse to sciencebased approaches, i.e. risk serves as a technocratic instrument by which sensitive issues are depoliticised. Siting controversies are instances where these different framings and understandings of risk co-exist. Multiple actors can use the same language, but can mean opposite things. Sometimes, the vocabulary of risk might even be used as a substitute for other non-risk related concerns. In this thesis, I have analysed the risk debates around mast siting as outcomes of a social process by which uncertainties that were raised by the siting of base stations - related to the authority of municipalities, spatial planning, or involvement of citizens - were converted into questions of risk, and hence scientific issues. I would like to argue that a thorough analysis of the power of risk, both as a legitimising and delegitimising force, in siting and technological controversies adds significantly to understanding the social, political and scientific dynamics that play out in these controversies.

Social scientists have to be careful not to resort to well-established risk explanations in their attempts to explain siting controversies. As I argued in chapter 2, some scholars in risk perception research do not question whether the issue is in fact best understood as a risk issue, and thus impose a particular understanding of the problem on their respondents. That is why I chose to use the notion of engagement in this 
thesis: as a constant reminder that citizens are not passive laypersons who suffer from deficits, but are active social beings. As long as we continue to portray siting or technological controversies as cases of the result of cognitive discrepancies between socalled laypersons and experts, and as long as the only solution is one of better risk communication, controversies will remain problems. In this thesis, I have argued that policymakers, industry, academics and society should start to see siting controversies as spontaneous, non-orchestrated forms of citizen involvement in local politics, and thus as political demands for participation. This reconceptualisation opens up a new array of possibilities in dealing with societal conflicts - not necessarily easier, cheaper or more effective - but more tailored to the essence of the problem.

Engaged citizens were usually well-embedded, active and social individuals who were part of a neighbourhood. I argue that they are the kind of citizens that the Dutch government has recently started to identify as possible engines of its doe-democratie (do-democracy) or vitale samenleving (vital society) (Ministerie van Binnenlandse Zaken en Koninkrijksrelaties, 2013). According to the Minister of the Interior and Kingdom Relations, the doe-democratie relates to the "changing relations between government, citizen and market [that] demand from 'the' government that it actively trusts and enables societal initiatives in the public domain, thereby increasingly letting go of its steering role and handing over its authority" (Ibid.: 9). In recent years, several governmental advisory bodies urged the government to involve citizens in political decisions and to use the expertise and knowledge that citizens have (see e.g. Raad voor het Openbaar Bestuur, 2012; Sociaal en Cultureel Planbureau, 2012; WRR, 2012). In its reaction to these calls, the government emphasised its desire to contribute to such a transition to a doe-democratie. The government, for example, tries to encourage citizens to become involved in their own neighbourhoods (see Noorderhaven and Timmers, 2009; Tonkens, 2010 for a discussion of two local citizen initiatives). However, the Wetenschappelijke Raad voor het Regeringsbeleid (The Netherlands Scientific Council for Government Policy) (2012), one of the advisory bodies that put the issue of citizen engagement on the agenda, observed that the government simultaneously under- and overestimated citizens about their possibilities for active engagement.

My analysis of mast siting controversies as forms of spontaneous citizen initiatives showed that the government underestimated the need for citizen involvement in base station siting. Instead, it portrayed the engagement of citizens with mast siting as a problem of deficits. How can we get siting controversies out of the negative limelight? We need to turn the focus on citizens in siting controversies upside down: see them as engagers in siting decisions with legitimate views, instead of 'protesters'. Citizen engagement should be taken seriously, instead of casting it aside as 'misunderstandings of science', 'resistance to change', or 'subjective risk perceptions'. If policy makers welcome citizen engagement as a form of genuine critique, siting controversies can be viewed as a healthy sign of democracy at work. This opens the path to more democratic solutions to siting controversies - solutions that move beyond risk. 


\title{
APPENDIX 1:
}

\section{Overview of case studies}

\author{
SPIJKENISSE \\ $\mathrm{NL}$ \\ 2004 \\ Municipality of Spijkenisse gives building permit to KPN [mobile phone company] to site a \\ October \\ mast with UMTS-antennas in Park Waterland. \\ 2005 \\ June \\ August \\ KPN starts construction work. \\ Neighbours notice construction work and ask the municipality questions about it. \\ The municipality organises an information session in which it and KPN explain the need for \\ the mast. \\ Citizens start to engage with the siting and establish Spijkenisse tegen Straling (Spijkenisse \\ against Radiation). \\ Local building corporation Maasdelta announces that it will not permit the siting of antennas \\ on any of its buildings.
}

October

November

December

2006

February

June

July

2007

March

April
The municipality asks KPN to wait with the siting of the mast. KPN halts the works.

Spijkenisse tegen Straling measures the electromagnetic fields in a flat complex in the city and investigates residents' health complaints.

KPN informs the municipality that it will resume the construction works shortly.

Spijkenisse tegen Straling and other neighbours prevent the siting of antennas in an existing electricity pylon in Park Waterland by tying themselves to the pylon.

The biggest political party in Spijkenisse (Onafhankelijk nieuw Spijkenisse) asks KPN to abandon the plan for mast siting. KPN sees no reason to do that.

Municipality withdraws the building permit of the mast. It awaits the results of a scientific study in Switzerland that will examine health effects of exposure to UMTS-like radiation. KPN appeals in court against the decision to withdraw the building permit.

By order of the municipality, research bureau TNO EPS measures the electromagnetic fields strengths on several roofs of flats in the city.

TNO EPS concludes research: the EMF strengths are far below the European exposure limits. On the basis of these measurements, the GGD (Community Health Services) reports that there is no health risk from living close to a base station.

The municipality examines the recently released results of the so-called 'Swiss study' that showed no adverse health effects from exposure to UMTS-like EMFs.

The three biggest political parties in Spijkenisse hand in a motion that calls for a temporarily halt of building permissions for the construction of UMTS-masts. It is adopted. KPN takes legal action.

The judge rules in favour of KPN: the UMTS-mast can be sited. KPN and the municipality slowly start to communicate again.

Spijkenisse against Radiation measures the EMF close to two schools and claims the exposure is too high. The school's headmasters are surprised and do not agree with these findings. By order of the municipality, research bureau TNO EPS repeats the measurements. 
May KPN starts the construction works on the UMTS-mast in Park Waterland.

June \& The construction site is vandalised

October

2008 The municipality ends its restrictive policy against UMTS-masts as one of the last Dutch March municipalities.

MAASTRICHT

$\mathrm{NL}$

\begin{tabular}{ll}
\hline 2010 & Neighbours are notified about the intended siting of a UMTS-mast in Heer, a neighbourhood \\
March & in Maastricht. The neighbourhood association (buurtplatform) initiates a working groups \\
& called 'UMTS-mast' and start to engage with the siting. \\
& The municipality organises an information evening. Some neighbours complain that they did \\
& not receive an invitation. The municipality decides to organise a second information evening \\
& in April.
\end{tabular}

April Second information session. Neighbours have questions about the choice of location. The municipality decides to investigate alternative options.

Neighbours hand over their submission of viewpoints (zienswijzen) with around 300 signatures from neighbours to the alderman for spatial planning (wethouder). The neighbours also have a private talk with him.

May until The municipality investigates the submission of viewpoints of the citizens to see whether September

2011

September The municipality informs the neighbourhood that it does not have any legal grounds to object to the siting of the base station. It argues that the neighbours cannot be accepted as claimants and thus their arguments have to be dismissed, but that it, nevertheless, has investigated some of the claims. The municipality investigated the height of the mast (39.9 meters), alternative locations and impact on protected wildlife.

October The working group of the neighbourhood association decides not to start a legal procedure against the municipality because they do not think to have much chance to win. The costs and efforts are considered to be too great.

... The mast is sited

\section{DRONGEN}

BE

2005

May

2006

January

May
NMBS (National Railway Company of Belgium) asks the municipality's permission to build a mobile phone mast for emergency communication next to the station in Drongen. The municipal advice to the regional planning official (Gewestelijk stedenbouwkundig ambtenaar, who is in charge of building permits) is negative because of visual pollution. The regional planning official gives a building permit to NMBS arguing that the societal need for railroad emergency communication outweighs visual pollution.

NMBS starts construction work on the mast. Neighbours were not informed and start to engage with the siting. They take immediate action and apply for a temporary injunction (kortgeding) in local court. They set up a neighbourhood group that will become known as 'Beperk de Straling' (Restrict the Radiation) and still exists today (2014). 
June

September

2007

April

June

October

November

December

2010

July

August
Several neighbours hand in a notice of objection (bezwaarschrift) with the municipality and appeal for cassation of the building permit with the Council of State (Raad van State).

The verdict on the temporary injunction is in favour of the neighbours.

The mobile phone operator Belgacom-Mobile applies for a building permit for the construction of a mast for mobile telephony next to a sports complex in the Keiskant in Drongen, a neighbourhood south of the station. The operator does not get a permit.

NMBS restarts construction work on the mast near the station in Drongen. Neighbours apply for a second temporary injunction (kortgeding) in local court.

The verdict on the temporary injunction is again in favour of the neighbours. NMBS cannot start works on the mast near the station. The company lodges an appeal against this decision in higher court.

Belgacom-Mobile again applies for a building permit near the sports complex in Keiskant, Drongen.

Neighbours of the Keiskant hand in notices of objections with the municipality against the siting of a mast with over a 1000 signatures.

NMBS starts to work again on the mast near the station, against the judge's ruling.

NMBS loses appeal in higher court and stops working on the mast.

Judgment of the First Auditor of the Council of State (who assesses the case and presents an opinion in open court): the mast cannot be sited because of lack of motivation concerning the health risks (at the time, there were no exposure limits in place because of the absence of Flemish regulation).

The regional planning official (Gewestelijk stedenbouwkundig ambtenaar) decides to withdraw the building permit for the mast close to the station in Drongen based on the report of the First Auditor of the Council of State

The mast is not sited

MAARKEDAL

BE

2008

November

December

2009

February

March
Neighbours of the Kafhoek, a neighbourhood in Maarkedal, receive notice from mobile phone operator Base that an existing radio mast will be replaced with a GSM-mast.

A few neighbours start to engage with the siting and go round the neighbourhood to invite others to a meeting in which they decide to draft a notice of objection that is submitted to the municipality a week later.

The owners of the youth centre next to the field where the mast will be sited receive an eco-award from the Flemish government. The owners take this opportunity to talk to the minister's representative about the mast.

The municipality gives a positive advice to the siting of the GSM-mast. Neighbours contact the regional authority in charge of the granting of the building permit and give their objections. They also contact several ministers.

Neighbours find out that there is no building permit for the existing radio mast and report this offence. 
June The regional authorities grant a permit to build the GSM-mast. A few neighbours start a legal procedure by appealing for cassation of the building permit with the Council of State (Raad van State).

September The neighbours organise a dinner to pay for the legal costs.

December The Council of State reverses the regional authorities' building permit on the basis of a lack of formal rules by which to assess the health effects of the electromagnetic fields from the antennas. At this time, there is no Flemish legislation on exposure limits. The mast is not sited

\section{NIEUWKOOP}

$\mathrm{NL}$

2008

May

September

December

November

2009

June

September

December

2010

March
The mobile phone operator KPN asks permission from the municipality to build two masts in Nieuwkoop, one close to the school and recreation terrains called de Dulen. The municipality starts the exemption procedure (vrijstellingsprocedure) for the siting of base stations.

Citizens and the primary school start to engage and collect notices of objection (zienswijzen) for the municipality.

The municipality organises an information evening for the neighbourhood. Engaged citizens collect signatures at the school gates for the notices of objection.

The local political party Midden Partij Nieuwkoop (MPN) submits a motion that calls for the establishment of a local antenna policy before allowing the siting of UMTS-antennas. The motion is adopted.

Engaged citizens hand over more than 120 notices of objection to the alderman for spatial planning (wethouder)

The municipality agrees with the mobile phone operator to postpone the exemption procedure until local antenna policy is provided.

The concept nota of the local antenna policy is ready. It is deposited for inspection at the city hall for 9 weeks.

The municipality receives 4 comments on the concept nota, all focused on possible health risks due to exposure to base stations.

Discussion of the antenna policy in the council meeting. Two local parties (Midden Partij Nieuwkoop and Progressief Nieuwkoop) submit an amendment: masts should not be allowed to be sited in densely populated areas. The amendment is not passed. The antenna policy states that health reasons do not play a role in granting building permits for masts.

Municipality grants building permit to the mobile phone operator for the two UMTS-masts in Nieuwkoop. 

Hague)

The mobile phone operator starts construction work on the mast. Engaged citizens start an interim provision procedure in court (voorlopige voorzieningsprocedure) to halt the siting.

Engaged citizens ask for expressions of support (a.o. donating money for the legal costs) through social media and newsletters of the school.

One of them also uses his public rights to speak in a council meeting about the local concerns about siting.

May Several political parties keep on addressing the issue by asking questions about the siting and submitting another motion to discuss alternative locations for the UMTS-masts with the mobile phone operator. The motion is not adopted.

An engaged citizen asks for access to the documents stating that there is inadequate mobile phone connection in Nieuwkoop based on the freedom of information law (Wet openbaarheid van bestuur). The municipality does not have these records.

July The interim provision procedure in court is in favour of the engaged citizens. The mobile phone operator halts the construction works.

December The citizens' appeal against the building permit with the local court is disallowed. The construction work of the mast is legal and can continue.

The same engaged citizens appeal against this court decision at the Council of State (Raad van State).

$2011 \quad$ The engaged citizens loose the appeal in higher court.

August There are no legal options anymore, but one of the engaged citizens suggests to do a socalled blood count study, where blood is taken from residents before the mast is sited, and again a few months later to detect any possible health effects from the exposure to

2012 the electromagnetic fields.

February The mast is sited

\section{EUVEREM}

NL

2010

March

2010

August

The municipality announces plans of mobile phone operator KPN/Ericsson to site a mast for mobile telephony in Euverem (part of the city of Gulpen-Wittem).

The municipality organises an information session in Euverem. During this evening, citizens express their objections against the location of the mast, in the main street of Euverem, close to a car park and playground. Even though all citizens want the mast because of lack of UMTS-reception in the village, they ask the municipality and mobile phone operator for alternative locations. The mobile phone operator is willing to look into it, and the alderman for spatial planning agrees to change the zoning place if necessary to allow siting in a different area.

The municipality grants a building permit for the construction of a UMTS-mast in Euverem, in a field next to a bungalow park, away from the main street of Euverem.

The mast is sited 


\section{APPENDIX 2:}

\section{Data collection}

Exploratory interviews

\begin{tabular}{|c|c|c|}
\hline MoNet (Mobile Network Operators the Netherlands) & 22-09-2009 & Baarn (NL) \\
\hline BIPT (Belgisch Instituut voor Postdiensten en Telecommunicatie) & $11-10-2010$ & Brussels (B) \\
\hline $\begin{array}{l}\text { Policy maker of the Environment, Nature and Energy Department } \\
\text { of the Flemish government (LNE) }\end{array}$ & 28-09-2010 & Brussels (B) \\
\hline Spokesperson GSM Operator Forum Belgium & 04-10-2010 & Brussels (B) \\
\hline
\end{tabular}

Interviews for case studies

\begin{tabular}{|c|c|c|c|c|c|}
\hline & Name & Date & $\begin{array}{l}\text { Duration of } \\
\text { interview }\end{array}$ & Location & $\begin{array}{l}\text { Information about } \\
\text { interviewee }\end{array}$ \\
\hline & \multicolumn{5}{|l|}{ Maastricht } \\
\hline M1 & Citizen 1 & 06-09-2011 & 40 min. & Maastricht & $\begin{array}{l}\text { Former chairman } \\
\text { buurtplatform } \\
\text { (neighbourhood association) }\end{array}$ \\
\hline M2 & Citizen 2 & 15-09-2011 & $1 \mathrm{~h} 10$ & Maastricht & $\begin{array}{l}\text { Active member of } \\
\text { buurtplatform } \\
\text { (neighbourhood association) }\end{array}$ \\
\hline M3 & Citizen 3 & 16-09-2011 & $1 \mathrm{~h} 00$ & Maastricht & $\begin{array}{l}\text { Chairman buurtplatform } \\
\text { (neighbourhood association) }\end{array}$ \\
\hline M4 & Citizen 4 & 24-10-2011 & $53 \mathrm{~min}$. & Maastricht & Resident of neighbourhood \\
\hline M5 & $\begin{array}{l}\text { City councilmember } \\
\text { (alderman) responsible } \\
\text { for antenna policy }\end{array}$ & 09-09-2011 & $26 \mathrm{~min}$. & Maastricht & \\
\hline M6 & $\begin{array}{l}\text { Staff member of } \\
\text { Antennebureau }\end{array}$ & 13-09-2011 & $\begin{array}{l}10 \text { min. } \\
\text { (telephone } \\
\text { call) }\end{array}$ & Maastricht & \\
\hline M7 & $\begin{array}{l}\text { Municipal official } \\
\text { working on antenna } \\
\text { policy }\end{array}$ & 21-09-2011 & 50 min. & Maastricht & \\
\hline
\end{tabular}




\begin{tabular}{|c|c|c|c|c|c|}
\hline & Name & Date & $\begin{array}{l}\text { Duration of } \\
\text { interview }\end{array}$ & Location & $\begin{array}{l}\text { Information about } \\
\text { interviewee }\end{array}$ \\
\hline M8 & $\begin{array}{l}\text { Municipal official } \\
\text { responsible for } \\
\text { relationships with the } \\
\text { neighbourhood in } \\
\text { question } \\
\text { (stadsdeelleider) }\end{array}$ & 04-10-2011 & $47 \mathrm{~min}$. & Maastricht & \\
\hline \multirow[t]{2}{*}{ M9 } & $\begin{array}{l}\text { Representatives of the } \\
\text { mobile phone operator }\end{array}$ & 21-10-2011 & $54 \mathrm{~min}$. & Maastricht & \\
\hline & Spijkenisse & & & & \\
\hline S1 & Citizen 1 & 01-11-2011 & $3 \mathrm{~h} 27$ & Spijkenisse & $\begin{array}{l}\text { Resident of neighbourhood } \\
\text { Founder of 'Spijkenisse tegen } \\
\text { Straling' (Spijkenisse against } \\
\text { Radiation) } \\
\text { Founder of International } \\
\text { EMF Alliance }\end{array}$ \\
\hline S2 & Citizen 2 & 26-11-2011 & $1 \mathrm{~h} 10$ & Spijkenisse & $\begin{array}{l}\text { Resident of neighbourhood } \\
\text { Co-founder of 'Spijkenisse } \\
\text { tegen Straling' (Spijkenisse } \\
\text { against Radiation) }\end{array}$ \\
\hline S3 & $\begin{array}{l}\text { Alderman (wethouder) } \\
\text { of spatial planning } \\
(2002-2006)\end{array}$ & 02-11-2011 & $57 \mathrm{~min}$. & Spijkenisse & $\begin{array}{l}\text { gave permission for the } \\
\text { siting of a mast }\end{array}$ \\
\hline S4 & $\begin{array}{l}\text { Alderman (wethouder) } \\
\text { of spatial planning } \\
(2006-2014)\end{array}$ & 02-11-2011 & 44 min. & Spijkenisse & $\begin{array}{l}\text { The contested mast siting } \\
\text { was one of the cases coming } \\
\text { from the previous } \\
\text { administration for the newly } \\
\text { appointed alderman in } 2006\end{array}$ \\
\hline S5 & $\begin{array}{l}\text { Alderman (wethouder) } \\
\text { of Sports, Culture, } \\
\text { Tourism, Education and } \\
\text { Welfare }\end{array}$ & $04-12-2011$ & $36 \mathrm{~min}$. & Spijkenisse & $\begin{array}{l}\text { Alderman at time of mast } \\
\text { siting controversy } \\
\text { Resident of neighbourhood }\end{array}$ \\
\hline S6 & $\begin{array}{l}\text { Representative mobile } \\
\text { phone operator }\end{array}$ & 03-11-2011 & 59 min. & Den Bosch & \\
\hline S7 & Councillor (raadslid) 1 & 04-12-2011 & $1 \mathrm{~h} 10$ & Spijkenisse & $\begin{array}{l}\text { Resident of neighbourhood } \\
\text { Opposed siting ( } P v d A)\end{array}$ \\
\hline S8 & Councillor (raadslid) 2 & 03-11-2011 & 1h04 & Spijkenisse & $\begin{array}{l}\text { Opposed siting (ONS } \\
\text { Spijkenisse) }\end{array}$ \\
\hline
\end{tabular}

\section{Nieuwkoop}

N1 Citizen $1 \quad$ 26-02-2011 1 h40 Nieuwkoop Resident of neighbourhood




\begin{tabular}{|c|c|c|c|c|c|}
\hline & Name & Date & $\begin{array}{l}\text { Duration of } \\
\text { interview }\end{array}$ & Location & $\begin{array}{l}\text { Information about } \\
\text { interviewee }\end{array}$ \\
\hline N2 & Citizen 2 & 02-03-2011 & $1 \mathrm{~h} 20$ & Nieuwkoop & Resident of neighbourhood \\
\hline N3 & Citizen 3 & 09-03-2011 & $1 \mathrm{~h} 15$ & Nieuwkoop & Resident of neighbourhood \\
\hline N4 & $\begin{array}{l}\text { Journalist of local } \\
\text { newspaper Witte } \\
\text { Weekblad }\end{array}$ & 03-03-2011 & $23 \mathrm{~min}$. & Nieuw-Vennep & $\begin{array}{l}\text { Wrote several pieces on the } \\
\text { mast siting controversy }\end{array}$ \\
\hline N5 & $\begin{array}{l}\text { Headmaster of primary } \\
\text { school }\end{array}$ & 08-03-2011 & $50 \mathrm{~min}$. & Nieuwkoop & \\
\hline N6 & $\begin{array}{l}\text { Municipal official of } \\
\text { Nieuwkoop working on } \\
\text { spatial planning }\end{array}$ & $21-02-2011$ & $53 \mathrm{~min}$. & Ter Aar & \\
\hline N7 & $\begin{array}{l}\text { Alderman (wethouder) } \\
\text { of spatial planning }\end{array}$ & 27-06-2011 & $59 \mathrm{~min}$. & Nieuwkoop & $\begin{array}{l}\text { Responsible for spatial } \\
\text { planning issues at time of } \\
\text { mast siting controversy }\end{array}$ \\
\hline N8 & City councillor (raadslid) & 09-03-2011 & 01h03 & $\begin{array}{l}\text { Alphen aan de } \\
\text { Rijn }\end{array}$ & $\begin{array}{l}\text { Opposed siting (Samen Beter } \\
\text { Nieuwkoop) }\end{array}$ \\
\hline N9 & $\begin{array}{l}\text { Staff member of } \\
\text { Antennebureau }\end{array}$ & $17-03-2011$ & $01 \mathrm{~h} 26$ & Amersfoort & $\begin{array}{l}\text { Presented at information } \\
\text { session about the siting of } \\
\text { the mast in Nieuwkoop }\end{array}$ \\
\hline N10 & $\begin{array}{l}2 \text { lawyers of mobile } \\
\text { phone operator }\end{array}$ & 04-03-2011 & $57 \mathrm{~min}$. & Amsterdam & \\
\hline N11 & $\begin{array}{l}\text { Representative of } \\
\text { mobile phone operator }\end{array}$ & $20-05-2011$ & $50 \mathrm{~min}$. & Den Bosch & $\begin{array}{l}\text { Was responsible for } \\
\text { particular siting in } \\
\text { Nieuwkoop }\end{array}$ \\
\hline
\end{tabular}

\section{Euverem}

\begin{tabular}{ll}
\hline E1 & Mayor of Gulpen- $\quad 27-02-2012 \quad 28 \mathrm{~min} . \quad$ Gulpen \\
& Wittem (Euverem is part \\
of Gulpen-Wittem) & \\
Informal talks with & \\
neighbours during & \\
information session &
\end{tabular}

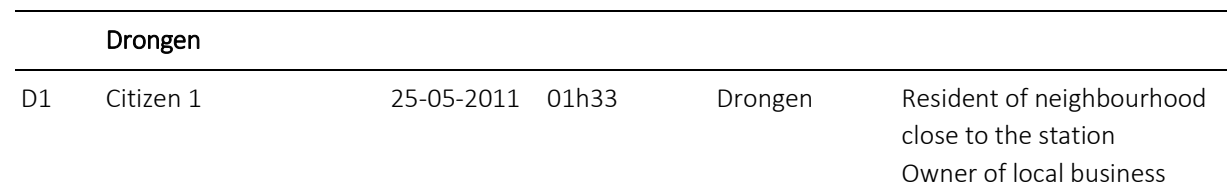




\begin{tabular}{|c|c|c|c|c|c|}
\hline & Name & Date & $\begin{array}{l}\text { Duration of } \\
\text { interview }\end{array}$ & Location & $\begin{array}{l}\text { Information about } \\
\text { interviewee }\end{array}$ \\
\hline D2 & Citizen 2 & 13-05-2011 & $2 \mathrm{~h}$ & Drongen & $\begin{array}{l}\text { Resident of neighbourhood } \\
\text { close to the station } \\
\text { Founder of Beperk de } \\
\text { Straling (Restrict the } \\
\text { Radiation) }\end{array}$ \\
\hline D3 & Citizen 3 & $11-05-2011$ & $01 \mathrm{~h} 29$ & Drongen & $\begin{array}{l}\text { Resident of neighbourhood } \\
\text { Keiskant } \\
\text { Former member of Beperk } \\
\text { de Straling }\end{array}$ \\
\hline D4 & $\begin{array}{l}\text { City councillor } \\
\text { (gemeenteraadslid) }\end{array}$ & $26-05-2011$ & $30 \mathrm{~min}$. & Drongen & $\begin{array}{l}\text { Resident of neighbourhood } \\
\text { close to the station } \\
\text { Opposed siting }\end{array}$ \\
\hline D5 & $\begin{array}{l}\text { Belgian Railways } \\
\text { communications } \\
\text { manager }\end{array}$ & $14-06-2011$ & $35 \mathrm{~min}$. & Brussels & $\begin{array}{l}\text { In charge of the mast close } \\
\text { to Drongen station that was } \\
\text { needed for the } \\
\text { communications network of } \\
\text { the Belgian Railroads }\end{array}$ \\
\hline D6 & $\begin{array}{l}\text { Alderman (schepen) of } \\
\text { spatial planning }\end{array}$ & 13-05-2011 & $53 \mathrm{~min}$. & Ghent & $\begin{array}{l}\text { Responsible for spatial } \\
\text { planning issues at time of } \\
\text { mast siting controversy }\end{array}$ \\
\hline D7 & Lawyer of citizens & $19-05-2011$ & 01h05 & Drongen & \\
\hline D8 & $\begin{array}{l}\text { Alderman (schepen) of } \\
\text { education }\end{array}$ & 05-07-2011 & $56 \mathrm{~min}$. & Ghent & $\begin{array}{l}\text { Personally involved in siting } \\
\text { controversies in Drongen } \\
\text { Called for banning masts } \\
\text { close to schools }\end{array}$ \\
\hline \multirow[t]{2}{*}{ D9 } & $\begin{array}{l}\text { Municipal official } \\
\text { responsible for } \\
\text { relationships with the } \\
\text { neighbourhood in } \\
\text { question (wijkregisseur) }\end{array}$ & 19-05-2011 & $39 \mathrm{~min}$. & Ghent & \\
\hline & Maarkedal & & & & \\
\hline MA1 & Citizen 1 & $15-04-2012$ & 01h18 & Maarkedal & $\begin{array}{l}\text { Resident of neighbourhood } \\
\text { Owner of youth centre }\end{array}$ \\
\hline MA2 & Citizen 2 & $15-04-2012$ & $51 \mathrm{~min}$. & Maarkedal & $\begin{array}{l}\text { Resident of neighbourhood } \\
\text { Owner of Bed and Breakfast }\end{array}$ \\
\hline MA3 & Citizen 3 & 04-04-2012 & $18 \mathrm{~min}$. & Maarkedal & Resident of neighbourhood \\
\hline MA4 & Citizen 4 & 04-05-2012 & $37 \mathrm{~min}$. & Maarkedal & Resident of neighbourhood \\
\hline MA5 & Mayor & 04-05-2012 & $38 \mathrm{~min}$. & Maarkedal & \\
\hline MA6 & Lawyer of citizens & 04-05-2012 & 01h05 & Maarkedal & \\
\hline
\end{tabular}




\begin{tabular}{|c|c|c|c|c|c|}
\hline & Name & Date & $\begin{array}{l}\text { Duration of } \\
\text { interview }\end{array}$ & Location & $\begin{array}{l}\text { Information about } \\
\text { interviewee }\end{array}$ \\
\hline MA7 & $\begin{array}{l}\text { Lawyer of mobile phone } \\
\text { operator }\end{array}$ & 01-05-2012 & $57 \mathrm{~min}$. & Antwerp & \\
\hline MA8 & $\begin{array}{l}\text { Lawyer of Flemish } \\
\text { government }\end{array}$ & $10-08-2012$ & $41 \mathrm{~min}$. & Ghent & $\begin{array}{l}\text { The Flemish government } \\
\text { became involved when } \\
\text { citizens appealed for } \\
\text { cassation of the building } \\
\text { permit of the mast with the } \\
\text { Council of State (Raad van } \\
\text { State). }\end{array}$ \\
\hline
\end{tabular}

Interviews Kennisplatform \& Klankbordgroep

\begin{tabular}{|c|c|c|c|c|c|}
\hline & Name & Date & $\begin{array}{l}\text { Duration of } \\
\text { interview }\end{array}$ & Location & Information about interviewee \\
\hline K1 & $\begin{array}{l}\text { Kennisplatform } \\
\text { staff }\end{array}$ & $24 / 04 / 2012$ & $01 h 42$ & Utrecht & $\begin{array}{l}\text { General secretary of the } \\
\text { Kennisplatform, employed at RIVM }\end{array}$ \\
\hline K2 & $\begin{array}{l}\text { Klankbordgroep } \\
\text { member }\end{array}$ & 07/05/2012 & $02 \mathrm{~h} 30$ & $\begin{array}{l}\text { Ede- } \\
\text { Wageningen }\end{array}$ & $\begin{array}{l}\text { Chairman of the Stichting } \\
\text { elektrohypersensitiviteit (EHS) } \\
\text { (Dutch ElektroHyperSensitivity } \\
\text { Foundation) with a seat in the } \\
\text { Klankbordgroep }\end{array}$ \\
\hline K3 & $\begin{array}{l}\text { Klankbordgroep } \\
\text { member }\end{array}$ & 07/05/2012 & $52 \mathrm{~min}$. & Telephone call & $\begin{array}{l}\text { Founder of StopUMTS with a seat in } \\
\text { the Klankbordgroep }\end{array}$ \\
\hline K4 & $\begin{array}{l}\text { Klankbordgroep } \\
\text { member }\end{array}$ & 08/05/2012 & $01 \mathrm{~h} 15$ & Delft & $\begin{array}{l}\text { Nederlands Instituut voor } \\
\text { Bouwbiologie en Ecologie (NIBE) } \\
\text { (The Dutch Institute for Building } \\
\text { Biology and Ecology) with a seat in } \\
\text { the Klankbordgroep }\end{array}$ \\
\hline K5 & Researcher & $14 / 05 / 2012$ & $01 \mathrm{~h} 06$ & Bilthoven & $\begin{array}{l}\text { Researcher at RIVM who is involved } \\
\text { in research into EMF and health }\end{array}$ \\
\hline K6 & $\begin{array}{l}\text { Kennisplatform } \\
\text { staff }\end{array}$ & $14 / 05 / 2012$ & $36 \mathrm{~min}$. & Bilthoven & $\begin{array}{l}\text { Chairman of the communication } \\
\text { forum of the Kennisplatform, } \\
\text { employed at RIVM }\end{array}$ \\
\hline K7 & $\begin{array}{l}\text { Kennisplatform } \\
\text { staff }\end{array}$ & $14 / 05 / 2012$ & $48 \mathrm{~min}$. & Utrecht & $\begin{array}{l}\text { Member of the communication } \\
\text { forum of the Kennisplatform, } \\
\text { employed at GGD }\end{array}$ \\
\hline K8 & $\begin{array}{l}\text { Klankbordgroep } \\
\text { member }\end{array}$ & $15 / 05 / 2012$ & 01h14 & Den Bosch & $\begin{array}{l}\text { MoNet (Mobile Network Operators } \\
\text { the Netherlands) with a seat in the } \\
\text { Klankbordgroep }\end{array}$ \\
\hline K9 & Advisory role & $16 / 05 / 2012$ & $01 \mathrm{~h} 15$ & The Hague & $\begin{array}{l}\text { Scientific Staff Member at } \\
\text { Gezondheidsraad }\end{array}$ \\
\hline K10 & Kennisplatform & 04/07/2012 & 01h14 & Bilthoven & Former member of the board of the \\
\hline
\end{tabular}




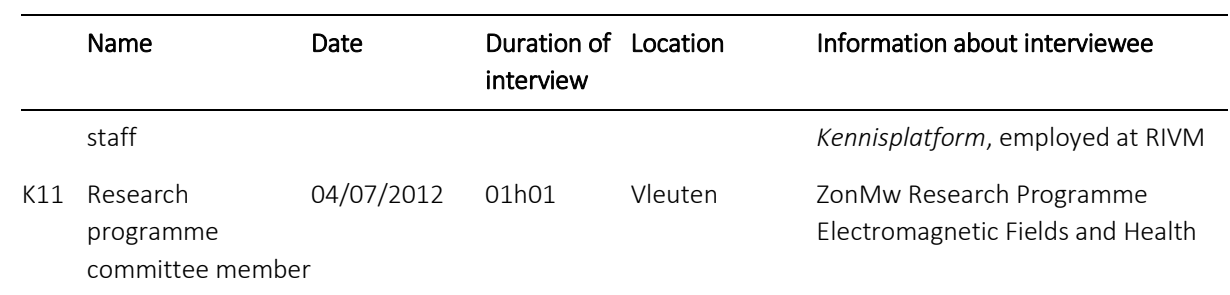




Activity

Euverem (NL)

Valkenswaard (NL) (with thanks to Bert de Graaff for sharing his notes with me)

Echt (NL)

\section{Courses}

Basiscursus Antennevraagstukken (Basic course Antenna

Questions) (Antennebureau)

Updatecursus Antennevraagstukken (Update course Antenna

Questions)

Zendantennes ... een hot item. Praktisch draaiboek (Base stations ... a hot item. Practical plan) (Department of Environment, Nature and Energy of Flanders)

\section{Conferences}

Low frequency electromagnetic field exposure and modulation of cellular functions, organised by the University of Wageningen and the Netherlands Organisation for Health Research and Development (ZonMw)

Modern health worries and idiopathic environmental intolerance in relation to symptoms. Research, assessment and treatment options, organised by the National Institute for Public Health and the Environment (RIVM) in Utrecht

\section{Meetings in relation to Kennisplatform EMV \& Gezondheid (Knoweldge Platform EMF \& Health)}

$5^{\text {th }}$ Klankbordgroep (Sounding Board) meeting

$6^{\text {th }}$ Klankbordgroep (Sounding Board) meeting

$7^{\text {th }}$ Klankbordgroep (Sounding Board) meeting

Bijeenkomst onderzoeker en maatschappij (Meeting research and society) - extra meeting with selected participants initiated by discussions in the Klankbordgroep

\section{Date Location}

23-03-2010 Euverem (Gulpen-Wittem)

(NL)

24-01-2011 Valkenswaard (NL)

14-08-2012 Echt-Susteren (NL)

07-10-2010 Amersfoort (NL)

17-03-2011 Amersfoort (NL)

09-06-2011 Hasselt (B)

16-09-2010 Wageningen (NL)

01-02-2011 Utrecht (NL)

03-02-2011 's-Hertogenbosch (NL)

20-10-2011 's-Hertogenbosch (NL)

15-03-2012 's-Hertogenbosch (NL)

06-09-2012 Amsterdam (NL) 


\section{APPENDIX 3: \\ Interview protocol case studies}

For the English translation, see page 218.

\section{Introduceer onderzoek, wat en waarom.}

\section{Algemeen}

- Kunt u vertellen hoe $\mathrm{u}$ in contact kwam met de thematiek van masten? Hoe bent u hierin betrokken geraakt? [experience and behaviour question]

- $\quad$ Kunt u kort zeggen wat $u$ vindt van het thema masten? Wat is uw mening hierover? [opinion and values question]

- Hoe belangrijk is het voor u? Wat zijn uw persoonlijke gevoelens bij het thema masten? Bent u er emotioneel bij betrokken? [feeling questions]

\section{Sociale beweging arena}

\section{Hoofdvragen:}

- Wat waren volgens u de problemen rondom het thema masten?

- Wat is uw mening over deze problemen?

- Hebt u deze problemen besproken met derden? Bent u ergens naartoe gegaan met uw mening over de problemen? Werd er naar u geluisterd?

\section{Deelvragen:}

Bredere context

- Wat is de aanloop geweest?

- Waren er al eerder discussies over andere kwesties?

Voortrekkers/leidende figuren/burgerbeweging/actievoerders

- Wie nam het voortouw? Waarom?

- Is er een groepje ontstaan rond een aantal voortrekkers?

- Wat is uw mening over deze groep mensen?

- Wat was uw relatie met hen? 
Zoektocht naar informatie

- Hebt u (meer) informatie gezocht over het onderwerp masten?

- Wat voor soort informatie hebt u gevonden?

- Waar hebt u de informatie over masten vandaan gehaald?

- Wat leert(de) de informatie u?

- Had u het gevoel er iets aan te hebben? [kwaliteit - betrouwbaarheid]

- [indien wetenschappelijke informatie]: Als ik dergelijke informatie lees, heb ik vaak moeite met het begrijpen van wat er staat. Is de informatie die u hebt gelezen duidelijk?

- Is uw mening over masten veranderd bij het vinden van nieuwe informatie?

Wetenschap en onzekerheden

Afhankelijk van in hoeverre de interviewee zelf dit onderwerp aanhaalt, leidt ik het onderwerp in aan de hand van een krantenartikel van die bepaalde casus waarin het er over gezondheidsrisico's wordt gesproken. Als het onderwerp al is besproken door de interviewee, dan haak ik daarop in.

- Wat is uw mening over deze berichten over gezondheidsrisico's? [opinion question]

- Hebt u zelf ervaringen met dergelijke risico's of verhalen over risico's? [experience question]

- Kwamen dit soort zorgen aan bod in uw buurt? [knowledge question]

\section{Politieke arena}

\section{Hoofdvragen:}

- Wat was de rol van de gemeente en de gemeentelijke politiek toen er sprake was van het plaatsen van een mast?

- Wat is uw mening over de rol van de gemeente en de gemeentelijke politiek?

\section{Deelvragen:}

\section{Gemeente}

- Hoe werd de thematiek van masten door de gemeente behandeld (indien van toepassing)?

- Hoe is het contact met de gemeente verlopen?

- Wat was het standpunt van de gemeente?

- Wat is uw mening over dit standpunt? 
Lokale politici

- Was er ook interesse in het thema masten van (lokale) politici?

- Wat was het standpunt van deze politici/die politicus?

- Wat is uw mening over dit standpunt?

Nationale politiek

- Is er ook contact geweest met ministers of politieke partijen op nationaal/regionaal niveau?

\section{Media arena}

\section{Hoofdvragen:}

- Heeft de media bericht over de mast?

- Wat is uw mening over deze berichtgeving?

- $\quad$ Laat u zich door de media informeren?

- Heeft het volgens u de gang van zaken beïnvloed?

\section{Legale arena}

\section{Hoofdvragen:}

- Is er op enig moment sprake geweest om een advocaat of jurist te raadplegen?

- Wat is uw mening over de rol van advocaten en juridische instanties in deze thematiek?

\section{Afsluiting}

- Is er nog iets dat u kwijt wil?

- $\quad$ Vond u het een prettig interview?

- Hebt u nog namen van mensen die ik echt moet interviewen? 


\section{English translation}

\section{Introduce research, what and why.}

\section{General}

- Can you tell me how you came into contact with the subject of masts? How did you become involved? [experience and behaviour question]

- Can you briefly say what you think about the issue of masts? What is your opinion? [opinion and values question]

- How important is it for you? What are your personal feelings with the issue? Are you emotionally involved? [feeling questions]

\section{Social movement arena}

Main questions:

- What were the problems of the issue of mast siting according to you?

- What is your opinion about these problems?

- $\quad$ Did you discuss these problems with others? Did you seek help or advice about your opinion? Were you listened to?

\section{Subquestions:}

Broader context

- What was the run-up?

- Were there previously discussions about other issues in the neighbourhood?

Pioneers/leading figures/civil movement/campaigners

- Who took the lead? Why?

- $\quad$ Did people join a group around these leaders?

- What is your opinion about this group of people?

- What was your relationship with them?

Search for information

- $\quad$ Did you search (more) information about the topic of masts?

- What kind of information did you find? 
- Where did you get the information about masts?

- What did you learn from this information?

- $\quad$ Did you have the feeling that it was useful? [quality - reliability]

- [in case of scientific information]: when I read scientific information, I often find it difficult to understand what it says. Was the information you read clear to you?

- Did your opinion about masts change when you found new information?

Science and uncertainties

Depending on whether the interviewee brings up this topic him/herself, I will introduce the issue by way of a newspaper article of that particular case in which health risks are mentioned. If the topic is already mentioned I will refer back to it.

- What is your opinion about these messages of health concerns? [opinion question]

- What are your experiences with these concerns? [experience question]

- Were these sort of concerns mentioned in your neighbourhood? [knowledge question]

\section{Political arena}

\section{Main questions:}

- What was the role of the municipality and local politics with the siting?

- What is your opinion about the role of the municipality concerning siting?

\section{Subquestions:}

Municipality

- How did the municipality deal with the issue of mast siting?

- How was the contact with the municipality?

- What was the municipality's viewpoint on the siting?

- What is your opinion about this viewpoint?

Local politics

- Was there also an interest from local politicians?

- What was their viewpoint?

- What is your opinion about this viewpoint? 
National politics

- Was there also contact with ministers or political parties on a national/regional level?

\section{Media arena}

\section{Main questions:}

- $\quad$ Did the media report about the mast?

- What is your opinion about this coverage?

- Were you informed by the media?

- Did it influence the course of events according to you?

\section{Legal arena}

Main questions:

- Do you know whether you or someone else considered consulting a lawyer?

- What is your opinion about the role of lawyers in this siting case?

\section{Conclusion}

- Is there something else you want to say?

- $\quad$ Did you like the interview?

- Do you have names of people that I could interview? 


\section{APPENDIX 4:}

\section{Atlas.ti Coding Scheme}

RQ: How to understand the societal dynamics and mechanisms [CODE: Dynamics], in particular the role of scientific knowledge and uncertainties therein [CODE: Dealing with science], that account for the emergence, sustainment or (possible) ending [CODE: Phasing] of local mast siting controversies [CODE: Networks]?

>> Why and how did wireless communication technology become a serious health concern that had/has to be dealt with primarily by scientific research? Or why and how did/does the risk framing dominate? [CODE: Why \& How]

>> How do actors in the public arena (the public, advisors, companies and policy bodies) and in local mast siting controversies use, construct, contest or ignore scientific knowledge regarding the RF EMF issue? [CODE: Dealing with science] [SUBCODE: Uncertainty]

\section{FRAMING}

How do actors define/see the problem?

- Health

Problem is framed as an issue of health risk

- Democracy

Problem is framed as spatial planning issue that involves democratic aspects

- $\quad$ Aesthetics

Problem is framed as landscape pollution

- Economics

Problem is framed as devaluation of property prices

- Location

Problem is framed as inadequate spatial planning issue

- Miscellaneous

- Why \& How

Why and how does risk framing dominate or push aside other framings? 


\section{DEALING WITH SCIENCE}

How do actors deal with science and uncertainty?

\section{DYNAMICS}

How do the actors act? What do they do?

- Resource mobilisation

Finding information, collecting money to pay for activities, establishing a citizen group, contacting media, etc.

- Expert mobilisation

Establishing contact with experts and professionals (scientists, Antennebureau, GGD, lawyers, etc.)

- Network mobilisation

Finding a support network of neighbours, friends, family, local politicians, journalists, etc.

\section{EMOTIONS}

What kind of emotions are expressed?

\section{PHASING (based on Benford and Snow, 2000)}

How do the actors act throughout the controversy?

- Diagnostic phase

Construction of sense of injustice

- $\quad$ Prognostic phase

Development of solutions, action plans and strategies

- Motivational phase

Creation of motivation to participate in engagement

\section{NETWORKS}

Different levels at which local controversies operate, the networks that are formed, multi-scale and multi-actor dynamics that are connected to the local issues

\section{OTHER}

Any other issues that cannot be categorised 


\section{BIBLIOGRAPHY}

Abels R (2006) Straling van masten. De angst steekt de kop op. Trouw, Available from: http://www.trouw.nl/tr/nl/4492/Nederland/article/detail/1507148/2006/07/20/Straling-vanmasten-De-angst-steekt-de-kop-op.dhtml, archived at http://www.webcitation.org/6Bm5XEUNP.

Agar J (2004) Constant Touch. A global history of the mobile phone. Cambridge, U.K.: Icon Books, Ltd. Allen BL (2003) Uneasy Alchemy. Cambridge, MA and London: The MIT Press.

ANP (1996) Radio Kootwijk verzet zich tegen megamasten. Trouw, 6th June.

Antennebureau (2002) Nationaal Antennebeleid. Vraagbak voor de uitvoering. Agentschap Telecom, Groningen, Available from: http://www.futura.cx/wp-content/uploads/2007/09/nabu_vraagbaak.pdf.

Antenneregister (2014) Antenneregister. Available from: http://www.antennebureau.nl/antenneregister (accessed 15 April 2014).

Arendt H (1963) On Revolution. New York: Viking Press.

Asveld L (2009) Trust and Criteria for Proof of Risk: The Case of Mobile Phone Technology in the Netherlands. In: Roeser S and Asveld L (eds), The Ethics of Technological Risk, London, UK: Earthscan, pp. 220-234.

Atkinson P and Hammersley M (2007) Ethnography. Principles in Practices. Third edition. New York: Routledge.

Baliatsas C, Van Kamp I, Lebret E, et al. (2012) Idiopathic environmental intolerance attributed to electromagnetic fields (IEI-EMF): A systematic review of identifying criteria. BMC Public Health, 12(1), 643.

Barnett J, Timotijevic L, Shepherd R, et al. (2007) Public responses to precautionary information from the Department of Health (UK) about possible health risks from mobile phones. Health Policy, 82(2), 240250.

Beck U (1992) Risk society. Towards a new modernity. London: Sage Publications.

Belgische Regering (2005) Koninklijk Besluit houdende de normering van zendmasten voor elektromagnetische golven tussen $10 \mathrm{MHz}$ en $10 \mathrm{GHz}, 10$ augustus 2005. Belgisch Staatsblad 175; nr. 291, 41189-93.

Benford R. and Snow DA (2000) Framing Processes and Social Movements: An Overview and Assessment. Annual Review of Sociology, 26, 611-39.

Beperk de Straling (2008) Wereldgezondheidsorganisatie (WGO). Available from: http://web.archive.org/web/20081006160013/http://www.beperkdestraling.org/Algemeen/ WGO.aspx (accessed 24 September 2013).

Bijker WE, Bal R and Hendriks R (2009) The paradox of scientific authority. Cambridge, MA: The MIT Press.

Blankesteijn M, Munnichs $G$ and van Drooge L (2014a) Contested science. Public controversies about science and policy. The Hague: Rathenau Instituut, Available from: http://www.rathenau.nl/uploads/tx_tferathenau/Contested_Science_Rathenau_Instituut.pdf.

Blankesteijn M, Munnichs G and van Drooge L (2014b) Wetenschap als strijdtoneel. Publieke controversen rond wetenschap en beleid. Den Haag: Rathenau Instituut, Available from: http://www.rathenau.nl/uploads/tx_tferathenau/Wetenschap_als_strijdtoneel_Publieke_controvers en_rond_wetenschap_en_beleid.pdf.

Boerema E (2001) Speech van Ed Boerema, gehouden bij de opening van het Nationaal Antennebureau te Groningen, op maandag 5 november 2001. Available from:

http://web.archive.org/web/20030529074352/http://www.antennebureau.nl/ SpeechEBoeremaopening.pdf.

Bogers RP, Bolte JFB, Houtveen JH, et al. (2013) Design of an ecological momentary assessment study of exposure to radiofrequency electromagnetic fields and non-specific physical symptoms. BMJ Open, 3(8), e002933.

Boholm $\AA$ (2004) Editorial: what are the new perspectives on siting controversy? Journal of Risk Research, $7(2), 99-100$. 
Boholm $\AA$ and Lofstedt RE (eds) (2013) Facility Siting: Risk, Power and Identity in Land Use Planning. London: Earthscan.

Bolte JF., Pruppers MJM, Pennders RMJ, et al. (2005) Vooronderzoek naar bezorgdheid over bassisstations voor mobiele telefonie. Report, Rijksinstituut voor Volksgezondheid en Milieu, Available from: http://www.rivm.nl/bibliotheek/rapporten/300010003.pdf.

Borraz O (2008) Risk and the changing nature of the state, presented at the First ISA FORUM - Session 04A Theorizing Risk and Uncertainty I, General Theorizing and Developments. Barcelona, Spain, Available from: http://www.cso.edu/upload/pdf_actualites/BORRAZ-com_092008.pdf

Borraz O (2011) From risk to the government of uncertainty: the case of mobile telephony. Journal of Risk Research, 14(8), 969-982.

Böschen S, Kastenhofer K, Rust I, et al. (2010) Scientific Nonknowledge and Its Political Dynamics: The Cases of Agri-Biotechnology and Mobile Phoning. Science, Technology and Human Values, 35(6), 783-811.

Bradbury JA (1989) The Policy Implications of Differing Concepts of Risks. Science, Technology and Human Values, 14(4), 380-399.

Bröer C (2006) Beleid vormt overlast. Hoe beleidsdiscoursen de beleving van geluid bepalen (Dissertatie). Universiteit van Amsterdam, Available from: http://home.medewerker.uva.nl/c.broer/bestanden/schijn.pdf (accessed 16 May 2014).

Bröer C, Duyvendak JW and Stuiver M (2010) Democratie en risico. Gezondheidsrisico's, beleid en protesten tegen mobiele telefoniezendmasten. Report, NWO, Available from: http://dare.uva.nl/document/170724.

Brown P, McCormick S, Mayer B, et al. (2006) 'A Lab of Our Own' Environmental Causation of Breast Cancer and Challenges to the Dominant Epidemiological Paradigm. Science, Technology \& Human Values, 31(5), 499-536.

Brusselse Hoofdstedelijke Gewest (2007) Ordonnantie betreffende de bescherming van het leefmilieu tegen de eventuele schadelijke effecten en hinder van niet-ioniserende stralingen. Belgisch Staatsblad 87, 13693-6.

Bucchi M and Neresini F (2008) Science and Public Participation. Third Edition. In: Hackett EJ, Amsterdamska O, Lynch M, et al. (eds), The Handbook of Science and Technology Studies, Cambridge \& London: The MIT Press, pp. 449-472.

Burgerministerie voor Stralingsbescherming (2012) Is er in Nederland al een ministerie dat de burgers beschermt tegen de schadelijke gevolgen van straling? Available from:

http://www.burgerministerievoorstralingsbescherming.nl/waarom-bmsb.html (accessed 3 December 2013).

Burgess A (2002) Comparing national responses to perceived health risks from mobile phone masts. Health, Risk and Society, 4(2), 175-188.

Burgess A (2004) Cellular phones, public fears, and a culture of precaution. Cambridge, UK: Cambridge University Press

Burgess A (2010) Media risk campaigning in the UK: from mobile phones to 'Baby P'. Journal of Risk Research, 13(1), 59-72.

Burningham K, Barnett J and Thrush D (2006) The limitations of the NIMBY concept for understanding public engagement with renewable energy technologies: a literature review. School of Environment and Development, University of Manchester, Manchester, Available from:

http://www.sed.manchester.ac.uk/research/beyond_nimbyism/.

Buurtplatform Vroendaal (n.d.) (G)een 40 meter hoge zendmast in onze mooie, groene wijk! [shortened version of notice of objection]. Available from: http://www.vroendaal.nl/portal/docs/UMTSwijkbrief.pdf (no longer active).

Callon M and Rabeharisoa V (2008) The Growing Engagement of Emergent Concerned Groups in Political and Economic Life: Lessons from the French Association of Neuromuscular Disease Patients. Science, Technology and Human Values, 33(2), 230-261.

Callon M, Lascoumes P and Barthe J (2009) Acting in an uncertain world. An essay on technical democracy. Cambridge, MA: The MIT Press. 
Campbell BL (1985) Uncertainty as Symbolic Action in Disputes among Experts. Social Studies of Science, 15(3), 429-453.

Carpenter D and Sage C (2007) Bio-Initiative Report. A Rationale for a Biologically-based Public Exposure Standard for Electromagnetic Fields (ELF and RF). Report, Available from:

http://www.bioinitiative.org/report/docs/report.pdf>.

Cayley D (2006) How to think about science with Brian Wynne. Ideas, Canadian Broadcasting Company, Available from: http://www.cbc.ca/ideas/episodes/2009/01/02/how-to-think-about-science-part-1--24-listen/ (accessed 21 January 2014).

Citizens Keiskant (Drongen) (2006) Bouwen van een telecommunicatiestation - Bespreking bezwaren. Available from: http://test.beperkdestraling.org/Bibliotheek/berichten/documenten/(document\%20\%2020061011)\%20Keiskantmastbespreking.doc (no longer available) (accessed 2 June 2010).

Clarke RH and Valentin J (2009) The History of ICRP and the Evolution of its Policies. Ann. ICRP, 39(1), 75110.

Collins HM (1985) Changing order. Replication and induction in scientific practice. London: Sage.

Collins HM and Pinch T (1982) Frames of Meaning: The Social Construction of Extraordinary Science. London: Routledge \& Kegan Paul.

Collins J (2010) Mobile phone masts, social rationalities and risk: negotiating lay perspectives on technological hazards. Journal of Risk Research, 13(5), 621-637.

Cousin M and Siegrist M (2010) The public's knowledge of mobile communication and its influence on base station siting preferences. Health, Risk and Society, 12(3), 231-250.

Cousin M, Dohle S and Siegrist M (2011) The impact of specific information provision on base station siting preferences. Journal of Risk Research, 14(6), 703-715.

D1 (2007) Collectief bezwaarschrift tegen telecommunicatiestation 'Keiskant'.

De Bruijn JA (2011) Framing. Over de macht van taal in de politiek. Amsterdam/Antwerpen: Atlas.

De Graaff MB (Bert) and Bröer C (2012) 'We are the canary in a coal mine': Establishing a disease category and a new health risk. Health, Risk \& Society, 14(2), 129-147.

De Marchi B, Pellizzoni L and Crivellari P (2009) Electromagnetic fields (mobile phones). In: Risk Bridge. Building robust, integrative inter-disciplinary governance of models for emerging and existing risks. Final report. Report, TNO Built Environment and Geosciences, Available from: http://www.riskbridge.eu/index.php?option=com_docman\&task=cat_view\&gid=26\&ltemid=6.

Departement Leefmilieu, Natuur en Energie (n.d.) Vragen over plaatsing. Available from: http://www.Ine.be/themas/milieu-en-gezondheid/zendantennes/vragen-over-plaatsing (accessed 30 December 2013).

De Rodij J (2006) UMTS-verzet onder gemeenten groeit. Weekblad Computable.

Devine-Wright P (2005) Beyond NIMBY-ism: towards an integrated framework for understanding public perceptions of wind energy. Wind Energy, 8, 125-139.

Devine-Wright P (2010) Renewable Energy and the Public: From NIMBY to Participation. Routledge.

Dohle S, Keller C and Siegrist M (2010) Conjoint Measurement of Base Station Siting Preferences. Human and Ecological Risk Assessment, 16(4), 825-836.

Dohle S, Keller C and Siegrist M (2012) Fear and anger: antecedents and consequences of emotional responses to mobile communication. Journal of Risk Research, 15(4), 435-446.

Douglas M and Wildavsky A (1982) Risk and culture. Berkeley, California: University of California Press.

Drake F (2006) Mobile phone masts: protesting the scientific evidence. Public Understanding of Science, 15(4), 387-410.

Duchêne A, Lakey J and Repacholi M (1991) IRPA Guidelines on Protection against Non-lonizing Radiation. The Collected Publications of the IRPA Non-lonizing Radiation Committee. Elsmford, NY, USA: Pergamon Press.

Earle TC and Siegrist M (2008) On the relationship between trust and fairness in environmental risk management. Risk Analysis, 28(5), 1395-413. 
Eerst onderzoek, dan masten (Berkel en Rodenrijs) (2005) Algemeen Dagblad Rotterdam, Rotterdam, 11th July, Available from:

http://www.ad.nl/ad/nl/1038/Rotterdam/article/detail/2412679/2005/10/30/Eerst-onderzoek-danmasten.dhtml, archived at http://www.webcitation.org/6Pc7ntTox (accessed 16 May 2014).

Eger H, Hagen KU, Lucas B, et al. (2004) Einfluß der räumlichen Nähe von Mobilfunksendeanlagen auf die Krebsinzidenz. Umwelt-Medizin-Gesellschaft, 4, 326-332.

Epstein S (1996) Impure Science: AIDS, Activism and the Politics of Knowledge. Berkeley, USA: University of California Press.

European Commission (n.d.) The Interphone Project: International case-control studies of cancer in relation to mobile phone use. Available from: http://ec.europa.eu/research/environment/pdf/env_health_projects/electromagnetic_fields/e-interphone.pdf.

European Commission (2007) Electromagnetic Fields. Special Eurobarometer 272a/Wave 66.2. - TNS Opinion \& Social. Brussels: European Commission, Available from: http://ec.europa.eu/public_opinion/archives/ebs/ebs_272a_en.pdf (accessed 3 February 2014).

European Commission (2010) Electromagnetic Fields. Special Eurobarometer 347, Wave 77.3. - TNS Opinion \& Social. Brussels, Available from: http://ec.europa.eu/public_opinion/archives/ebs/ebs_347_en.pdf (accessed 3 February 2014).

European Parliament (2008) Resolution of 4 September 2008 on the mid-term review of the European Environment and Health Action Plan 2004-2010. Brussels, Available from:

http://www.europarl.europa.eu/sides/getDoc.do?type=TA\&language=EN\&reference=P6-TA-20080410 (accessed 25 June 2014).

Felt U and Wynne (2007) Taking European Knowledge society seriously. Report of the expert group on science and governance. Report, European Commission, Available from: http://www.bmbf.de/pub/EuropeanKnowledge(6).pdf.

Fischer F (2005) Are scientists irrational? Risk assessment in practical reason. In: Leach M, Scoones I, and Wynne B (eds), Science and citizens: globalization and the challenge of engagement, New York, U.S.A.: Zed Books, Ltd.

Frickel S, Gibbon S, Howard J, et al. (2010) Undone Science: Charting Social Movement and Civil Society Challenges to Research Agenda Setting. Science, Technology and Human Values, 35(4), 444-473.

Funtowicz SO and Ravetz JR (1990) Uncertainty and quality in science for policy. Dordrecht: The Netherlands: Kluwer Academic Publishers.

Futrell R (2003) Framing Processes, Cognitive Liberation, and NIMBY Protest in the U.S. Chemical Weapons Disposal Conflict. Sociological Inquiry, 73(3), 359-86.

Geen UMTS totdat risico's duidelijk zijn (2005) Utrechts Nieuwsblad, 29th January, Available from: http://www.stopumts.nl/doc.php/Berichten\%20Nederland/251/redir, archived at http://www.webcitation.org/6Pc7v0IFL.

Gemeente Haarlemmermeer (2005) Verslag van de vergadering van de raadssessie gemeente Haarlemmermeer op donderdag 20 januari 2005. Available from: http://web.archive.org/web/20050203201717/http://www.haarlemmermeer.nl/gvscriptvk/ (accessed 16 May 2014).

Gemeente Spijkenisse (2006) Spijkenisse werkt niet mee aan nieuwe UMTS mast. Available from: http://www.spijkenisse.nl/live/content_item.jsp?selected=23349 (not available anymore).

Gezondheidsraad (1926) Verslagen en Mededelingen van de Volksgezondheid. De gevaren, verbonden aan het gebruik van röntgen- en daarmede gelijk te stellen stralen, en middelen ter voorkoming van die gevaren. Den Haag: Gezondheidsraad.

Gezondheidsraad (1975) Advies inzake de gevaren van microgolfstraling en de daaruit afgeleide aanvaardbare stralingsniveaus (Hazards of microwave radiation and radiation levels derived there-from). Den Haag: Ministerie van Volksgezondheid en Milieuhygiëne.

Gezondheidsraad (1978) Aanvaardbare niveaus voor elektromagnetische straling in het golflengtegebied tussen 100 nm en $1 \mathrm{~mm}$ (micrometerstraling). Publicatie nr 1978/06. Report. 
Gezondheidsraad (1997) Radiofrequente electromagnetische velden (300 Hz-300 GHz)/Radiofrequency electromagnetic fields $(300 \mathrm{~Hz}-300 \mathrm{GHz}$ ). Den Haag: Gezondheidsraad, Available from: http://www.gezondheidsraad.nl/nl/adviezen/radiofrequente-elektromagnetische-velden-300-hz300-ghz.

Gezondheidsraad (1999) Public health impact of large airports [Grote luchthavens en gezondheid]. Den Haag: Gezondheidsraad: committee on the health impacts of large airports, Available from: http://www.gezondheidsraad.nl/sites/default/files/9914E.PDF (accessed 24 June 2014).

Gezondheidsraad (2003) Gezondheidseffecten van blootstelling aan radiofrequente elektromagnetische velden. Aanbevelingen voor onderzoek. Den Haag: Gezondheidsraad, Available from: http://www.gezondheidsraad.nl/sites/default/files/0303n.pdf (accessed 2 May 2014).

Gezondheidsraad (2004) TNO study on the effects of GSM and UMTS signals on well-being and cognition. Review and recommendations for further research. Den Haag: Gezondheidsraad, Available from: http://www.gezondheidsraad.nl/sites/default/files/GSMenUMTSengels.pdf.

Gezondheidsraad (2005) Electromagnetische Velden: Jaarbericht 2005 / Electromagnetic Fields: Annual Update 2005. Den Haag: Gezondheidsraad, Available from: http://www.gezondheidsraad.nl/sites/default/files/0514NE.pdf

Gezondheidsraad (2008) Biolnitiative report. Den Haag: Gezondheidsraad, Available from: http://www.gezondheidsraad.nl/en/publications/bioinitiative-report-0.

Gezondheidsraad (2010) Invitational Conference 'Is health a state or an ability? Towards a dynamic concept of health'. Report of the meeting December 10-11, 2009. Den Haag: Gezondheidsraad, Available from: http://www.gezondheidsraad.nl/nl/adviezen/wat-gezondheid-verslag-van-een-internationaleconferentie (accessed 27 June 2014).

Gezondheidsraad: Commissie elektromagnetische velden (2000) GSM-basisstations. Den Haag: Gezondheidsraad, Available from: http://www.gezondheidsraad.nl/sites/default/files/0016N.PDF.

GGD Hollands Noorden (2007) Gezondheidseffecten van GSM en UMTS basisstations (presentation). Available from: http://archiefandijk.nl/download/961145/cd/presentatie+ggd+umts+nov+2007.ppt.

GGD Limburg Noord (2012) GSM- en UMTS-basisstations (presentation). Available from: http://www.groenesporenwolf.nl/mast/Presentatie\%20Echt\%20140812.pdf, archived at http://www.webcitation.org/6PggclS2h.

GGD Regio Nijmegen (2012) Gezondheidseffecten van GSM/UMTS basisstations (presentation). Available from:

http://www.beuningen.nl/dsresource?type=pdf\&objectid=default:9345\&versionid=\&subobjectname $=$.

Gibson CM (2006) Citizens at the center. A new approach to civic engagement. The Case Foundation, Available from: http://casefoundation.org/sites/default/files/citizens-at-the-center.pdf.

Goffman E (1974) Frame Analysis: An Essay on the Organization of Experience. New York: Harper Colophon.

Goldhaber MK, Polen MR and Hiatt RA (1988) The risk of miscarriage and birth defects among women who use visual display terminals during pregnancy. American Journal of Industrial Medicine, 13(6), 695706.

Golinski J (2008) Making Natural Knowledge: Constructivism and the History of Science. Chicago \& London: University of Chicago Press.

Grove-White R, Macnaghten P and Wynne B (2000) Wising Up. The public and new technologies. Lancaster, UK: The Centre for the Study of Environmental Change Institute for Environment, Philosophy and Public Policy, Lancaster University, Available from: http://www.csec.lancs.ac.uk/docs/wising_upmacnaghten.pdf.

Haarlemmermeer.nl (1999a) College Haarlemmermeer stelt beleid GSM-installaties vast (Persbericht), Available from: from http://web.archive.org/web/19981205194118/ http://www.haarlemmermeer.nl/core.html (accessed 12 December 2013). 
Haarlemmermeer.nl (1999b) Uitspraak rechtbank Haarlem: Bouwvergunning nodig voor GSM-

zendinstallaties (Persbericht), Available from:

http://web.archive.org/web/19981205194118/http://www.haarlemmermeer.nl/core.html (accessed

20 December 2013).

Hannigan JA (1995) Environmental Sociology. A Social Constructionist perspective. London: Routledge.

Hardell L, Carlberg M and Mild KH (2006) Case-control study of the association between the use of cellular and cordless telephones and malignant brain tumors diagnosed during 2000-2003. Environmental Research, 100(2), 232-41.

Hardell L, Carlberg M, Söderqvist F, et al. (2007) Long-term use of cellular phones and brain tumours: Increased risk associated with use for $>10$ years. Occupational and Environmental Medicine, 64(9), 626-32.

Harremoës P, Gee D, MacGarvin M, et al. (2001) Late Lessons from early warnings: the precautionary principle 1896-2000. Report, European Environment Agency, Available from: http://reports.eea.eu.int/environmental_issue_report_2001_22/en/Issue_Report_No_22.pdf.

Heeel lang geleden... (2009) geen supermast op de kafhoek, Available from: http://geensupermastopdekafhoek.blogspot.nl/, archived at http://www.webcitation.org/6PGuqzDyP (accessed 2 May 2014).

Hermans MA, Fox T and van Asselt MBA (2011) Risk Governance. In: Roeser S, Hillerbrand R, Sandin P, et al. (eds), Handbook of Risk Theory. Epistemology, Decision Theory, Ethics, and Social Implications of Risk, Dordrecht, Heidelberg, London, New York: Springer.

Hermans MA and van Asselt MBA (2012) Inzichten over maatschappelijke controverses rondom masten voor mobiele telefonie. Magazine Nationale veiligheid en Crisisbeheersing, 10(5), 29-31.

Hermans MA and van Asselt MBA (2013) Engagement bezorgde burgers bij plaatsen zendmasten voor mobiele telefonie. Magazine Nationale veiligheid en Crisisbeheersing, 11(6), 48-49.

Hermans MA, van Asselt MBA and Passchier WF (2014) Zorgen over zendmasten: hoe een maatschappelijk debat verengd wordt tot de definiëring van gezondheidsrisico's. Bestuurskunde, 23(2), 12-20.

Hess DJ (1997) Science Studies. An advanced introduction. New York and London: New York University Press.

Hess DJ (2001) Ethnography and the Development of Science and Technology Studies. In: Atkinson P, Coffey A, Delamont S, et al. (eds), Handbook of Ethnography, London: SAGE Publications Ltd, pp. 234-245.

Hess DJ and Coley JS (2014) Wireless smart meters and public acceptance: The environment, limited choices, and precautionary politics. Public Understanding of Science, 23(6), 688-702.

Het Grondwettelijke Hof (2009) Arrest in zake de beroepen tot vernietiging van de ordonnantie van het Brusselse Hoofdstedelijke Gewest van 1 maart 2007 betreffende de bescherming van het leefmilieu tegen de eventuele schadelijke effecten en hinder van niet-ioniserende stralingen, ingesteld door de $n v$ $<<$ Belgacom Mobile > en anderen, en door de Ministerraad. Arrest 2/2009. [Rolnummers 4277 en 4278], 1-39.

Hilgartner S (2000) Science on Stage: Expert Advice as Public Drama. Stanford, CA, USA: Stanford University Press.

Hoge Gezondheidsraad (2009) Advies van de Hoge Gezondheidsraad nr. 8519. Advies betreffende de normering van zendmasten. Brussel: Hoge Gezondheidsraad.

Hoge Gezondheidsraad: Onderafdeling III/4 Stralingen (2002) De GSM? Veilig mobiel telefoneren? Gebundelde adviezen 2002. Brussel: Hoge Gezondheidsraad, Available from:

http://www.milieugezondheid.be/dossiers/gsm/HGR\%202002\%20De\%20GSM,\%20Veilig\%20mobiel\% 20telefoneren.pdf.

Hood C, Rothstein H and Baldwin R (2001) The government of risk: Understanding risk regulation regimes. Oxford: Oxford University Press.

Huijben M (2008) Umts-mast vlakbij huizen Vliegende Vennen. BN DeStem, 28th November, Available from: http://www.bndestem.nl/regio/oosterhout/umts-mast-vlakbij-huizen-vliegende-vennen-1.420369.

Hutter H-P, Moshammer H, Wallner P, et al. (2004) Public perception of risk concerning cell towers and mobile phones. Sozial- und Praventivmedizin, 49(1), 62-6. 
Infoplease (2007) Cell phone subscribers in the U.S., 1985-2010. Available from:

http://www.infoplease.com/ipa/A0933563.html (accessed 10 December 2013).

Ingezonden brief (2009) Hier geen mast, Available from: http://www.hiergeenmast.nl/de_golfbreker.html, not available anymore.

International Agency for Research on Cancer (IARC) (n.d.) The INTERPHONE Study. Funding. Available from: http://INTERPHONE.iarc.fr/INTERPHONE_funding.php (accessed 12 March 2013).

International Commission on Non-Ionising Radiation Protection (1998) ICNIRP Guidelines for limiting exposure to time-varying electric, magnetic and electromagnetic fields (up to $300 \mathrm{GHz}$ ). Health Physics, $74(4), 494-522$.

International Commission on Non-Ionizing Radiation Protection (ICNIRP) (n.d.) Aim and Roots. Available from: http://icnirp.org/aim.htm (accessed 12 March 2013).

International Commission on Radiological Protection (1928) International Recommendations for X-ray and Radium Protection. Report, Available from: http://www.icrp.org/publications.asp.

International Risk Governance Council (2007) An Introduction to the IRGC Risk Governance Framework. Geneva: IRGC, Available from: http://irgc.org/wpcontent/uploads/2012/04/An_introduction_to_the_IRGC_Risk_Governance_Framework.pdf.

International Risk Governance Council (2005) Risk Governance: Towards an Integrative Approach (IRGC White Paper No1). Geneva: IRGC, Available from: http://irgc.org/wpcontent/uploads/2012/04/IRGC_WP_No_1_Risk_Governance_reprinted_version_3.pdf.

Irwin A (1995) Citizen Science. A study of people, expertise and sustainable development. London: Routledge.

Irwin A and Wynne B (1996) Misunderstanding science. The public reconstruction of science and technology. Cambridge: Cambridge University Press.

Jasanoff S (1990) The fifth branch: Science advisers as policy makers. Cambridge, USA: Harvard University Press.

Jasanoff S (1999) The Songlines of Risk. Environmental Values, 8, 135-152.

Jasanoff S (2005) Designs on Nature. Science and Democracy in Europe and the United States. Princeton: Princeton University Press.

Jasanoff S and Wynne B (1998) Science and decisionmaking. In: Rayner S and Malone EL (eds), Human choice and climate change, pp. 1-87.

Kasperson RE, Renn O, Slovic P, et al. (1988) The Social Amplification of Risk: A Conceptual Framework. Risk Analysis, 8(2), 177-187.

Kennisplatform Elektromagnetische Velden (n.d.) The Knowledge Platform. www.kennisplatform.nl, Available from: http://www.kennisplatform.nl/English/knowlegdeplatform.aspx (accessed 2 April 2014).

Kennisplatform Elektromagnetische Velden en Gezondheid (2008a) Kennisbericht. Het Bio-Initiative rapport: een pleidooi voor lagere blootstellingslimieten. Available from:

http://www.kennisplatform.nl/Files/Kennisberichten/kennisbericht\%202008-001\%20bioInitiative.pdf (accessed 16 May 2014).

Kennisplatform Elektromagnetische Velden en Gezondheid (2008b) Vastgesteld verslag Klankbordgroep EMV. Kennisplatform Elektromagnetische Velden en Gezondheid. Verslag, eerste bijeenkomst 16 april 2008, 's Hertogenbosch. Bilthoven: Kennisplatform Elektromagnetische Velden en Gezondheid, Available from:

http://www.kennisplatform.nl/Files/Documents/verslag\%20eerste\%20bijeenkomst\%20klankbordgro ep\%20emv\%2016\%20april\%202008.pdf.

Kennisplatform Elektromagnetische Velden en Gezondheid (2008c) Verslag oprichtingsfase 2007-2008. Bilthoven: Kennisplatform Elektromagnetische Velden en Gezondheid, Available from: http://www.kennisplatform.nl/Files/jaarverslag/Verslag\%20oprichtingsfase\%20Kennisplatform\%20E MV\%20\%202007\%20-\%202008.pdf. 
Kennisplatform Elektromagnetische Velden en Gezondheid (2009a) Kennisplatform Elektromagnetische Velden en Gezondheid. Verslag, tweede bijeenkomst 20 november 2008, 's Hertogenbosch. Bilthoven: Kennisplatform Elektromagnetische Velden en Gezondheid, Available from:

http://www.kennisplatform.nl/Files/Documents/verslag\%20eerste\%20bijeenkomst\%20klankbordgro ep\%20emv\%2016\%20april\%202008.pdf.

Kennisplatform Elektromagnetische Velden en Gezondheid (2009b) Vastgesteld verslag Klankbordgroep EMV. Kennisplatform Elektromagnetische Velden en Gezondheid. Verslag, derde bijeenkomst 27 mei 2009, 's Hertogenbosch. Bilthoven: Kennisplatform Elektromagnetische Velden en Gezondheid, Available from:

http://www.kennisplatform.nl/Files/Documents/definitieve\%20verslag\%203e\%20klankbordgroep.pdf

Kennisplatform Elektromagnetische Velden en Gezondheid (2013) Kennisplatform Elektromagnetische Velden en Gezondheid. Verslag, tiende bijeenkomst 26 september 2013, 's Hertogenbosch. Bilthoven: Kennisplatform Elektromagnetische Velden en Gezondheid, Available from: http://www.kennisplatform.nl/Files/Klankbordgroep/KP-EMV_klankbordverslag\%2010_web.pdf.

Kennisplatform Elektromagnetische Velden en Gezondheid (n.d.) Klankbordgroepbijeenkomsten. www.kennisplatform.nl, Available from:

http://www.kennisplatform.nl/organisatie/Klankbordgroep/Klankbordgroep.aspx, archived at http://www.webcitation.org/6QDrg1Qwz.

Kheifets L, Swanson J, Kandel S, et al. (2010) Risk Governance for Mobile Phones, Power Lines, and Other EMF Technologies. Risk Analysis, 30(10), 1481-94.

Klinke A and Renn O (2002) A new approach to risk evaluation and management: risk-based, precautionbased, and discourse-based strategies. Risk Analysis, 22(6), 1071-1094.

Köhler W (1990) Langdurig werken met beeldscherm kan kans ziekten iets verhogen. NRC Handelsblad, 30th June.

Köhler W (1999) Stralend op de daken. Gsm-antennes of flats zaaien onrust. NRC Handelsblad, 20th February.

Lammerse A (1999) De angst voor de GSM-mast rukt op. De Volkskrant, 30th June.

Lash S and Wynne B (1992) Introduction. In: Beck U (ed.), Risk Society. Towards a New Modernity, London: Sage Publications, pp. 1-10.

Lauwerier F (2009) 'Waarom steunt de gemeente ons niet?'. Uitbaters Kafhoek zetten strijd tegen bouw gsm-mast voort. De Standaard, 18th February.

Law A and McNeish W (2007) Contesting the New Irrational Model. A Case Study of Mobile Phone Mast Protest. Sociology, 42(3), 439-456.

Leach M (2005) MMR mobilisation: citizens and science in a British vaccine controversy. Brighton: Institute of Development Studies, Available from: http://www.ids.ac.uk/files/Wp247.pdf.

Leach M, Scoones I and Wynne B (2005) Science and citizens: globalization and the challenge of engagement. New York, U.S.A.: Zed Books, Itd.

Leighninger M (2006) The next form of democracy. How expert rule is giving way to shared governance... and why politics will never be the same. Nashville: Vanderbilt University Press.

Lezaun J and Soneryd L (2007) Consulting citizens: technologies of elicitation and the mobility of publics. Public Understanding of Science, 16(3), 279-297.

Ligtenberg L (1993) Draagbare telefoon zorgt voor paniek in VS. NRC Handelsblad, February 2.

Lindell B (1996) A History of Radiation Protection. Radiat Prot Dosimetry, 68(1-2), 83-95.

Löfstedt RE (2005) Risk Management in Post-Trust Societies. Hampshire and New York, USA: Palgrave Macmillan.

Luloff AE, Albrecht SL and Bourke L (1998) NIMBY and the hazardous and toxic waste siting dilemma: The need for concept clarification. Society \& Natural Resources, 11(1), 81-89.

M1 (2011) Bezwaarschrift Plaatsing mast mobiele communicatie Oude Molenweg (Notice of objection siting mast mobile communication Oude Molenweg). 
Martin B and Richards E (1995) Scientific Knowledge, Controversy and Public Decision Making. In: Jasanoff S, Markle GE, Petersen JC, et al. (eds), The Handbook of Science and Technology Studies, Thousand Oaks, London, New Dehli: Sage Publications.

Merton RK (1973) The Sociology of Science: Theoretical and Empirical Investigations. University of Chicago Press.

Mesman J (2002) Ervaren pioniers. Omgaan met twijfel in de intensive care voor pasgeborenen (Dissertatie). Maastricht: Maastricht University.

Michael M (1992) Lay Discourses of Science: Science-in-General, Science-in-Particular, and Self. Science, Technology and Human Values, 17(3), 313-333.

Millstone E (2007) Can food safety policy-making be both scientifically and democratically legitimated? If so, how? Journal of Agricultural and Environmental Ethics, 20(5), 483-508.

Millstone E, Van Zwanenberg P, Marris C, et al. (2004) Science in Trade Disputes Related to Potential Risks: Comparative Case Studies. Seville: Joint Research Centre, Institute for Prospective Technological Studies (JRC-IPTS), Available from: http://ftp.jrc.es/EURdoc/eur21301en.pdf.

Millstone E, van Zwanenberg P, Levidow L, et al. (2008) Risk-assessment Policies: Differences across Jurisdictions. ESTO Report. Seville: Joint Research Centre, Institute for Prospective Technological Studies, Available from: http://ftp.jrc.es/EURdoc/JRC37719.pdf.

Ministerie van Economische Zaken (1998) Wet van 19 oktober 1998, houdende regels inzake de telecommunicatie (Telecommunicatiewet). Den Haag: Ministerie van Economische Zaken, Available from: http://wetten.overheid.nl/BWBR0009950/Opschrift/geldigheidsdatum_19-02-2013.

Ministerie van Economische Zaken, Ministerie van Volkshuisvesting Ruimtelijke Ordening en Milieubeheer \& Vereniging van Nederlandse Gemeenten, et al. (2005) Evaluatie antenneconvenant in het kader van het Nationaal Antennebeleid betreffende vergunningvrije antenne-installaties voor mobiele telecommunicatie. 'De tweede evaluatie'. Den Haag: Ministerie van Economische Zaken, Ministerie van Volkshuisvesting Ruimtelijke Ordening en Milieubeheer \& Vereniging Nederlandse Gemeenten, Available from: http://www.antennebureau.nl/binaries/content/assets/antennebureau/Wet-enregelgeving/Tweede_evaluatie_Antenneconvenant.pdf.

Ministerie van Volkshuisvesting Ruimtelijke Ordening en Milieubeheer (2006) Geen enkel effect UMTSstraling op gezondheid (Persbericht). Den Haag: Ministerie van Volkshuisvesting Ruimtelijke Ordening en Milieubeheer, Available from:

http://www.kennisplatformveiligmobielnetwerk.info/Persbericht_Van_Geel_UMTS_Juni_2006.pdf, archived at http://www.webcitation.org/6U28FlgMo.

Ministerie van Binnenlandse Zaken en Koninkrijksrelaties (2013) Vaststelling van de begrotingsstaten van het ministerie van Binnenlandse Zaken en Koninkrijksrelaties (VII) en van de begrotingsstaten van Wonen en Rijksdienst (XVIII) voor het jaar 2013. Brief aan de Voorzitter van de Tweede Kamer der Staten-Generaal. Den Haag: 9 juli 2013. Tweede Kamer, vergaderjaar 2012-2013, 33400-VII nr. 79. SDU Uitgevers, Available from:

https://www.eerstekamer.nl/behandeling/20130709/brief_regering_kabinetsstandpunt/document3/ $\mathrm{f}=/$ vjbin2t6fize.pdf (accessed 25 June 2014).

Ministerie van Volksgezondheid, Welzijn en Sport (2000) GSM-problematiek (correspondence). Available from: http://www.stopumts.nl/pdf/minvws_bawa_12dec08.pdf (accessed 12 December 2013).

MoNet - Mobiele Netwerkoperators Nederland (1999a) Gedragscode over GSM antenne-installaties. Available from: http://web.archive.org/web/20001007001527/http://www.monet-info.nl/ (accessed 21 February 2013).

MoNet - Mobiele Netwerkoperators Nederland (1999b) Speech voor conferentie Vereniging Nederlandse Gemeenten, 4de kwartaal 1999. Available from: http://web.archive.org/web/20001007001527/http://www.monet-info.nl/ (accessed 21 February 2013).

MoNet - Mobiele Netwerkoperators Nederland (2000) Homepage MoNet - Mobiele Netwerkoperators Nederland. Available from: http://web.archive.org/web/20001007001527/http://www.monetinfo.nl/ (accessed 21 February 2013). 
Moore A and Stilgoe J (2009) Experts and Anecdotes. The role of 'anecdotal evidence' in public scientific controversies. Science, Technology \& Human Values, 34(5), 654-677.

Mouffe C (2000) The democratic paradox. London: Verso.

Mouffe C (2005) Some reflections on an agonistic approach to the public. In: Latour B and Weibel P (eds), Making things public. Atmospheres of democracy, Karlsruhe: ZKM/Center for art and media.

Mourik R (2004) Did water kill the cows? The distribution and democratisation of risk, responsibility and liability in a Dutch agricultural controversy on water pollution and cattle sickness (Dissertation). Maastricht: Pallas Publications.

Murphy M (2006) Sick building syndrome and the problem of uncertainty. Hampshire and New York, USA: Palgrave Macmillan.

N1 (2004) Pleitnota en motivering beroepschrift voorlopige voorzieningsprocedure UMTS mast Nieuwkoop. Available from:

http://www.stopumts.nl/doc.php/Juridische\%20Informatie/4972/pleitnota_en_motivering_beroepsc hrift_voorlopige_voorzieningsprocedure_umts_mast_nieuwkoop._(upd), archived at http://www.webcitation.org/6NGDGFtsO.

n.a. (1994) 'Zendmasten gevaar voor de gezondheid'; Hoogleraar: straling kan kanker veroorzaken. Algemeen Dagblad, 18th March.

n.a. (1999a) Libertel moet een gsm-mast slopen na klachten buurt. de Volkskrant, 25th June.

n.a. (1999b) Plek voor GSM-masten moeilijk te vinden. Algemeen Dagblad, 24th February.

n.a. (2005a) Strijd tegen straling. Algemeen Dagblad, 29th October.

n.a. (2005b) Umts-studie brengt risico's niet in kaart. Reformatorisch Dagblad, 30th May, Available from: http://www.stopumts.nl/doc.php/Berichten\%20Nederland/392/\%26\%238222\%3Bumts-

studie_brengt_risico\%26\%238217\%3Bs_niet_in_kaart\%26\%238221\%3B_reformatorisch_dagblad.

n.a. (2006a) Van Geel opgelucht na umts-studie. Reformatorisch Dagblad, 6th July.

n.a. (2006b) Verzet GGD'en tegen procedure zendmast. Reformatorisch Dagblad, 8th June, Available from: http://www.refdag.nl/nieuws/binnenland/verzet_ggd_en_tegen_procedure_zendmast_1_171128.

n.a (2009) Ingezonden brief Hier geen mast. Available from:

http://www.hiergeenmast.nl/de_golfbreker.html (not available anymore).

Nelkin D (1979) Controversy: Politics of technical decisions. Beverly Hills, CA: Sage.

Nicholson J (2001) Sick Cell. Representations of Cellular Telephone Use in North America. Media Culture Journal, 4(3), Available from: http://journal.media-culture.org.au/0106/cell.php (accessed 24 June 2014).

Nielsen JB, Elstein A, Gyrd-Hansen D, et al. (2010) Effects of Alternative Styles of Risk Information on EMF Risk Perception. Bioelectromagnetics, 31(7), 504-512.

Nieuwenhuis W (1998) Radarstraling van Hawks blijft onrust wekken, NRC Handelsblad, 12th August.

Noorderhaven $\mathrm{N}$ and Timmers A (2009) Naar een nieuwe rolverdeling in de openbare ruimte: Bewonersparticipatie in Hellevoetsluis. Bestuurswetenschappen, 63(6), 35-53.

Nowotny H, Scott P and Gibbons M (2001) Re-Thinking Science: Knowledge and the Public in an Age of Uncertainty. Cambridge, UK: Polity Press in association with Blackwell Publishers.

Onrust in wijken over UMTS-zenders. Wachten op Zürich (2005) Tubantia, 21st August, Available from: http://www.stopumts.nl/doc.php/Berichten\%20Nederland/537/onrust_in_wijken_over_umtszenders_wachten_op_z\%FCrich_tubantia (accessed 12 May 2014).

Oreskes N (2004) Science and Public Policy: What's proof got to do with it? Environmental Science \& Policy, 7, 369-383.

Ottinger G (2013a) Changing Knowledge, Local Knowledge, and Knowledge Gaps. STS Insights into Procedural Justice. Science, Technology \& Human Values, 38(2), 250-270.

Ottinger G (2013b) Refining Expertise. How Responsible Engineers Subvert Environmental Justice Challenges. New York and London: New York University Press.

Owens S and Cowell R (2002) Land and Limits: Interpreting Sustainability in the Planning Process. London: Routledge. 
Parlement en Politiek (2013) Natuur- en milieuorganisaties. Available from: http://www.parlement.com/id/vh8Inhrq7yb3/natuur_en_milieuorganisaties.

Passchier WF (1999) Verspraak onder hoogspanning [Wireless tensions] (Oratie), Maastricht: Universiteit Maastricht, Available from: http://home.planet.nl/ wfpas/sci20.htm\#um_2.

Patton MQ (2002) Qualitative Research \& Evaluation Methods. 3rd ed. Thousand Oaks: Sage.

Pepermans Y and Loots I (2011) Wie wint zaait, zal storm oogsten? De sociale aanvaardbaarheid van onshore windenergie. Wilrijk: Universiteit Antwerpen - Instituut voor Milieu en Duurzame Ontwikkeling.

Petts J (2004) Barriers to participation and deliberation in risk decisions: evidence from waste management. Journal of Risk Research, 7(2), 115-133.

Petts J, Horlick-Jones T and Murdock G (2001) Social amplification of risk: The media and the public. Suffolk: HSE Books, Available from: http://www.hse.gov.uk/research/crr_pdf/2001/crr01329.pdf.

Pickering A (1992) Science as Practice and Culture. Chicago: University of Chicago Press.

Pickering AR (1984) Constructing quarks: A sociological history of particle physics. Edinburgh: Edinburgh University Press.

Pidgeon NF, Kasperson RE and Slovic P (2003) The Social Amplification of Risk. Cambridge: Cambridge University Press.

Pielke RAJ (2007) The Honest Broker. Making Sense of Science in Policy and Politics. Cambridge, UK: Cambridge University Press.

Plough A and Krimsky S (1987) The emergence of risk communications studies: social and political context. Science Technology and Human Values, 12(3-4), 4-10.

Polder M (2005) Met stralingsmeter bij de antennes. De Botlek, 25th October.

Power M (2004) The Risk Management of Everything: Rethinking the Politics of Uncertainty. London: DEMOS, Available from: http://www.demos.co.uk/files/riskmanagementofeverything.pdf?1240939425 (accessed 15 April 2014).

Raad voor het Openbaar Bestuur (2012) Cahier. Loslaten in vertrouwen. Beschouwingen van adviesraden over een nieuwe verhouding tussen overheid, markt én samenleving. Den Haag: Raad voor Openbaar Bestuur, Available from: http://www.robrfv.nl/rob/publicaties_rob/publicatie_rob/184/Loslaten+in+vertrouwen (accessed 25 June 2014).

Regel SJ, Negovetic S, Röösli M, et al. (2006) UMTS Base Station-like Exposure, Well-Being, and Cognitive Performance. Environmental Health Perspectives, 114(8), 1270-1275.

Reijnders L (1994) Straling ongevaarlijk is loze kreet. Algemeen Dagblad, 4th August.

Renn O (2008) Risk Governance. Coping with Uncertainty in a Complex World. London: Earthscan.

Rieks (2009) Rieks // 08-08-2009 om 22:19 [Online reactions to television programme 'De Golfoorlog': over stralen en kwalen' broadcasted by Canvas]. Available from:

http://actua.canvas.be/panorama/panorama-98-de-golfoorlog/, not available anymore.

Ritsema A (1996) Radio Kootwijk vreest straling van zendmasten, NRC Handelsblad, 4th December.

Rosanvallon P (2008) Counter-Democracy. Politics in an age of distrust. Cambridge, U.K.: Cambridge University Press.

Rothstein H, Huber M and Gaskell G (2006) A theory of risk colonisation : the spiralling regulatory logics of societal and institutional risk. Economy and society, 35(1), 91-112.

Rothstein H, Borraz O and Huber M (2013) Risk and the limits of governance: Exploring varied patterns of risk-based governance across Europe. Regulation \& Governance, 7(2), 215-235.

Ruddat M, Sautter A, Renn O, et al. (2010) Communication about a communication technology. Journal of Risk Research, 13(3), 261-278.

Salomon D and Borraz O (2007) Regulating the risks of mobile phone base stations: a comparative study in 5 European countries. In: Repacholi M, van Deventer E, and Ravazzani P (eds), Base stations and wireless networks: exposures and health consequences: Proceedings international workshop on base stations and wireless networks: Exposures and health consequences, World Health Organisation, pp. 113-26, Available from: http://whqlibdoc.who.int/publications/2007/9789241595612_eng.pdf.

Sarewitz D (2004) How science makes environmental controversies worse. Environmental Science \& Policy, 7, 385-403. 
Schütz H and Wiedemann PM (2005) How to deal with dissent among experts. Risk evaluation of EMF in a scientific dialogue. Journal of Risk Research, 8(6), 531-545.

Seale C (2004) Researching Society and Culture. London: Sage.

Shapin S and Schaffer S (1985) Leviathan and the Air-Pump: Hobbes, Boyle, and the Experimental Life. Princeton, New Jersey: Princeton University Press.

Short JJF and Rosa EA (2004) Some principles for siting controversy decisions: lessons from the US experience with high level nuclear waste. Journal of Risk Research, 7(2), 135-152.

Siegrist M, Earle TC, Gutscher H, et al. (2005) Perception of mobile phone and base station risks. Risk Analysis, 25(5), 1253-1264.

Sismondo S (2012) An introduction to science and technology studies. Second Edition. Chichester, United Kingdom: Wiley-Blackwell.

Slob M and Staman J (2012) Beleid en het bewijsbeest. Een verkenning van verwachtingen en praktijken rond evidence based policy. Den Haag: Rathenau Instituut. Available from: http://www.rathenau.nl/uploads/tx_tferathenau/Beleid_en_het_bewijsbeest-Rathenau.pdf.

Slovic P (1987) Perception of risk. Science, 236(4799), 280-285.

Slovic P (2000) The perception of risk. Risk society and policy series, London: Earthscan Publications.

Slovic P, Fischhoff B and Lichtenstein S (1982) Why Study Risk Perception. Risk Analysis, 2(2), 83-93.

Sociaal en Cultureel Planbureau (2012) Een beroep op de burger. Minder verzorgingsstaat, meer eigen verantwoordelijkheid? Sociaal en Cultureel Rapport 2012. Den Haag: Sociaal en Cultureel Planbureau, Available from:

http://www.scp.nl/Publicaties/Alle_publicaties/Publicaties_2012/Een_beroep_op_de_burger (accessed 25 June 2014).

Soneryd $L$ (2007) Deliberations on the unknown the unsensed and the unsayable? Public protests and the development of third-generation mobile phones in Sweden. Science, Technology \& Human Values, 32(3), 287-314.

Spector M and Kitsuse J (1987) Constructing Social Problems. New York: Aldine De Gruyter.

Staatssecretaris van Verkeer en Waterstaat (2000) Nationaal Antennebeleid. Brief van de Staatssecretaris van Verkeer en Waterstaat aan de Voorzitter van de Tweede Kamer der Staten-Generaal; 12 december 2000. Tweede Kamer der Staten-Generaal; vergaderjaar 2000-2001, 27 561, nr. 1. Sdu Uitgevers, Den Haag.

Staatssecretaris van Verkeer en Waterstaat (2001) Speech van de staatssecretaris van Verkeer en Waterstaat, drs. J.M. de Vries, gehouden bij de opening van het Nationaal Antennebureau te Groningen, op maandag 5 november 2001. Available from:

http://web.archive.org/web/20030529103652/http://www.antennebureau.nl/SpeechMdeVriesopeni ng.pdf (accessed 5 February 2014).

Staatssecretaris van Verkeer en Waterstaat, Minister van Volkshuisvesting, Ruimtelijke Ordening en Milieubeheer, Vereniging van Nederlandse Gemeenten, et al. (2002) Convenant in het kader van het nationaal antennebeleid inzake vergunningvrije antenne-installaties voor mobiele telecommunicatie. Den Haag.

Starr C (1969) Social benefit versus technological risk. Science, 165(899), 1232-1238.

Steneck NH (1984) The Microwave Debate. Cambridge, MA: The MIT Press.

Stichting Milieuziektes (n.d.) Homepage. www.milieuziektes.nl, Available from:

http://www.milieuziektes.nl/, archived at http://www.webcitation.org/6QZy7vMTT (accessed 24 June 2014).

Stilgoe J (2005) Controlling mobile phone health risks in the UK. A fragile discourse of compliance. Science and Public Policy, 32(1), 55-64.

Stilgoe J (2007) The co-production of public uncertainty: UK scientific advice on mobile phone health risks. Public Understanding of Science, 16(1), 45-61.

Stilgoe J, Owen R and Macnaghten P (2013) Developing a framework for responsible innovation. Research Policy, 42(9), 1568-1580.

Stirling A (1998) Risk at a turning point? Journal of Risk Research, 1(2), 97-109. 
Stirling A (2001) On science and precaution in the management of technological risk. Volume II. Case studies. Report, European Commission, Joint Research Centre, Available from:

http://www.jrc.es/home/publications/publications.html.

StopUMTS (n.d.) Belangenverstrengeling overheid, TNO en providers? www.stopumts.nl, Available from: http://www.stopumts.nl/showpic.php?picid=46, archived at http://www.webcitation.org/6AcWaF1ul.

StopUMTS (2004a) Homepage. Available from: http://web.archive.org/web/20040603214457/http://www.StopUMTS.nl/ (accessed 24 September 2013).

StopUMTS (2004b) Kunnen we de overheid dan niet vertrouwen als het over onze gezondheid gaat? Available from:

http://web.archive.org/web/20060219074147/http://www.StopUMTS.nl/doc.php/Veel\%20gestelde \%20vragen/51 (accessed 24 September 2013).

StopUMTS (2004c) Wie is de initiatiefnemer van StopUMTS.nl? Available from: http://web.archive.org/web/20040804042020/http://www.StopUMTS.nl/ (accessed 24 September 2013).

StopUMTS (2005) Welkom bij StopUMTS.nl. Available from: http://web.archive.org/web/20050829092920/http://www.StopUMTS.nl/ (accessed 24 September 2013).

StopUMTS (2006a) Reactie van StopUMTS op het Zwitserse Onderzoek, Available from: http://www.stopumts.nl/pdf/persbericht_zwitserland.pdf (accessed 16 January 2014).

StopUMTS (2006b) Straling: de feiten, Available from: http://www.stopumts.nl/pdf/folderwetenschap.pdf, archived at http://www.webcitation.org/6053iwM7X.

Stralingsrisico's (2013) Waarom een nieuw gespreksplatform? Available from: http://web.archive.org/web/20070824211908/http://www.stralingsrisicos.nl/index.php?option=com _content\&task=view\&id=1\&Itemid=2.

Sturgis P and Allum N (2004) Science in Society: Re-Evaluating the Deficit Model of Public Attitudes. Public Understanding of Science, 13(1), 55-74.

Swa D (2009) @ON7WP [Online reactions to Radio 1 Interview with Guy Vandenbosch]. Available from: http://www.radio1.be/programmas/peeters-pichal/algemene-stralingsbe\%C3\%AFnvloeding?page=5, archived at http://www.webcitation.org/6DphFfjwn.

Team StopUMTS (2010) Commentaar op 'Tweede informatieavond Vroendaal' on www.vroendaal.nl, Available from:

http://www.vroendaal.nl/portal/index.php?option=com_content\&view=article\&id=203:tweedeinformatieavond-umts-zendmast\&catid=92:ingekomen-post\&ltemid=96, archived at http://www.webcitation.org/6PWCQXYgL.

Tesh SN (2000) Uncertain Hazards. Environmental activists and Scientific Proof. Ithaca and London: Cornell University Press.

Tesh SN and Williams BA (1996) Identity Politics, Disinterested Politics, and Environmental Justice. Polity, 28(3), 285-305.

Thalmann AT and Wiedemann PM (2006) Beliefs and Emotionality in Risk Appraisals. Journal of Risk Research, 9(5), 453-466.

The Council of the European Union (1999) Council Recommendation of 12 July 1999 on the limitation of exposure of the general public to electromagnetic fields ( $0 \mathrm{~Hz}$ to $300 \mathrm{GHz}$ ). Official Journal of the European Communities, L199, 59-70.

The INTERPHONE Study Group (2010) Brain tumour risk in relation to mobile telephone use: results of the INTERPHONE international case-control study. International Journal of Epidemiology, 39(3), 675694.

Timotijevic L and Barnett J (2006) Managing the possible health risks of mobile telecommunications: Public understandings of precautionary action and advice. Health, Risk and Society, 8(2), 143-164. 
Tonkens E (2010) De kwaliteit van burgerparticipatie in de stad: de casus bewonersbudgetten. Bestuurskunde, 19, 34-43.

Tulloch J and Lupton D (2001) Risk, the mass media and personal biography: Revisiting Beck's 'knowledge, media and information society. European Journal of Cultural Studies, 4(1), 5-27.

Tweede Kamer (1981) Vragen van de leden Van den Broek, Lansink en Weijers (allen C.D.A.) over stralingslekkage van magnetronovens; 27 maart 1981. Tweede Kamer der Staten-Generaal; vergaderjaar 1980-1981, nr. 1093. Sdu Uitgevers, Den Haag.

Tweede Kamer (1988a) Vragen van de leden Braams en Nijhuis (beiden V.V.D.) over elektromagnetische straling rond zendparken; 16 maart 1988. Tweede Kamer der Staten-Generaal; vergaderjaar 19871988, nr. 463. Sdu Uitgevers, Den Haag.

Tweede Kamer (1988b) Vragen van de leden Verspaget (P.v.d.A.) en Vriens-Auerbach (C.D.A.) over elektromagnetische straling van radio- en t.v.-zenders; 25 februari 1988. Tweede Kamer der StatenGeneraal; vergaderjaar 1987-1988, nr. 431 (Herdruk). Sdu Uitgevers, Den Haag.

Tweede Kamer (1996) Vragen van het lid Esselink (CDA) over het verband tussen gezondheidsproblemen en de elektromagnetische straling van de korte-golfzender; 3 april 1996. Tweede Kamer der StatenGeneraal; vergaderjaar 1995-1996, nr. 1141. Sdu Uitgevers, Den Haag.

Tweede Kamer (1997) Vaststelling van de begroting van de uitgaven en de ontvangsten van het Ministerie van Verkeer en Waterstaat (XII) voor het jaar 1997. Verslag van een schriftelijk overleg; 29 augustus 1997. Tweede Kamer der Staten-Generaal; vergaderjaar 1996-1997, 25000 XII, nr. 53. Sdu Uitgevers, Den Haag.

Tweede Kamer (1998) Handelingen Tweede Kamer. Het wetsvoorstel Regels inzake de telecommunicatie (Telecommunicatiewet), Telecommunicatiewet (25533), 26 maart 1998. Tweede Kamer der StatenGeneraal; vergaderjaar 1997-1998, vergadernummer 66- 4911. Sdu Uitgevers, Den Haag.

Tweede Kamer (2000) Nationaal Antennebeleid, 8 december 2000. Ministerie van Verkeer en Waterstaat, Directoraat-Generaal Telecommunicatie en Post. Tweede Kamer der Staten-Generaal; vergaderjaar 2000-2001, 27 561, nr. 2. Sdu Uitgevers, Den Haag.

Tweede Kamer (2001a) Nationaal Antennebeleid. Motie van het lid Wagenaar c.S., voorgesteld in het notaoverleg van 14 mei 2001. Tweede Kamer der Staten-Generaal, vergaderjaar 2000-2001, 27 561, nr. 10. Sdu Uitgevers, Den Haag.

Tweede Kamer (2001b) Nationaal Antennebeleid. Verslag van een notaoverleg; 16 mei 2001. Tweede Kamer der Staten-Generaal; vergaderjaar 2000-2001, 27 561, p. 6. Sdu Uitgevers, Den Haag.

Tweede Kamer (2004a) Nationaal Antennebeleid. Brief van de staatssecretaris van Volkshuisvesting, Ruimtelijke Ordening en Milieubeheer; 21 juni 2004. Tweede Kamer der Staten-Generaal, vergaderjaar 20032004, 27 561, nr. 18. Sdu Uitgevers, Den Haag.

Tweede Kamer (2004b) Vragen van het lid Van Dam (PvdA) aan de minister van Economische Zaken over de mogelijke schadelijkheid voor de gezondheid van UMTS-straling en de inspraakprocedure bij plaatsing UMTS-antennes; 31 maart 2004. Tweede Kamer der Staten-Generaal; vergaderjaar 2003-2004, Aanhangsel. Sdu Uitgevers, Den Haag.

Tweede Kamer (2005) Nationaal Antennebeleid. Brief van de Minister van Economische Zaken en de Staatssecretaris van Volkshuisvesting, Ruimtelijke Ordening en Milieubeheer aan de Voorzitter van de Tweede Kamer der Staten-Generaal, 16 november 2005. Tweede Kamer der Staten-Generaal; vergaderjaar 2005-2006, 27 561, nr. 24. Sdu Uitgevers, Den Haag.

Tweede Kamer (2006a) Nationaal Antennebeleid. Brief van de Minister van Economische Zaken; 16 januari 2006. Tweede Kamer der Staten-Generaal, vergaderjaar 2005-2006, 27 561, nr. 25. Sdu Uitgevers, Den Haag.

Tweede Kamer (2006b) Nationaal Antennebeleid. Brief van de staatssecretaris van Volkshuisvesting, Ruimtelijke Ordening en Milieubeheer; 6 juni 2006. Tweede Kamer der Staten-Generaal, vergaderjaar 20052006, 27 561, nr. 28. Sdu Uitgevers.

Tweede Kamer (2006c) Nationaal Antennebeleid. Verslag van een algemeen overleg; 9 oktober 2006. Tweede Kamer der Staten-Generaal; vergaderjaar 2006-2007, 27 561, nr. 29. Sdu Uitgevers, Den Haag. 
Tweede Kamer (2006d) Vragen van het lid Van Dam (PvdA) aan de staatssecretaris van Volkshuisvesting, Ruimtelijke Ordening en Milieubeheer over de berichtgeving naar aanleiding van het Zwitserse UMTSonderzoek; 13 juni 2006. Tweede Kamer der Staten-Generaal; vergaderjaar 2005-2006, Aanhangsel 1837. Sdu Uitgevers

US NRC (National Research Council) (1983) Risk Assessment in the Federal Government: Managing the Process. Committee on the Institutional Means for Assessment of Risks to Public Health, National Research Council, Washington D.C.: US National Academies Press.

van Asselt MBA (2000) Perspectives on Uncertainty and Risk. The PRIMA Approach to Decision Support (Dissertation). Dordrecht, The Netherlands: Kluwer Academic Publishers.

van Asselt MBA (2005) The complex significance of uncertainty in a risk era: logics, manners and strategies in use. International Journal of Risk Assessment and Management, 5(2/3/4), 125-158.

van Asselt MBA and Renn O (2011) Risk Governance. Journal of Risk Research, 14(4), 431-449.

van Asselt MBA and Vos E (2008) Wrestling with uncertain risks: EU regulation of GMOs and the uncertainty paradox. Journal of Risk Research, 11(1), 281 - 300.

van Asselt MBA, Passchier W and Krayer von Krauss M (2009) Uncertainty assessment. An analysis of regulatory science on wireless communication technology, RF EMF and cancer risks. Maastricht: Maastricht University.

van Asselt MBA, Versluis E and Vos E (2013) Balancing between Trade and Risk: Integrating Legal and Social Science Perspectives. London and New York: Routledge.

van der Hoeven P (2012) Het succes van een kwaliteitskrant. De ontstaansgeschiedenis van NRC Handelsblad. Amsterdam: Promotheus.

van der Sluijs JP (2012) Uncertainty and Dissent in Climate Risk Assessment: A Post-Normal Perspective. Nature and Culture, 7(2), 174-195.

van Dijk H, van Rongen E, Eggermont G, et al. (2011) The role of scientific advisory bodies in precautionbased risk governance illustrated with the issue of uncertain health effects of electromagnetic fields. Journal of Risk Research, 14(4), 451-456.

Van Dinther M (1996) Dorpelingen vrezen komst nieuwe zender, De Volkskrant, 16th November.

van Dongen D, Claassen L, Smid T, et al. (2013) People's responses to risks of electromagnetic fields and trust in government policy: the role of perceived risk, benefits and control. Journal of Risk Research, 16(8), 945-957.

van Leeuwen G, Lagendijk J, van Leersum B, et al. (1999) APM Thermal \& RF Modelling of Cellular Phones (THERMIC). Work Package 2: Demonstration and validation of the models. The Hague: TNO Physics and Electronics Laboratory.

van Oirschot J (2006) Ogen gericht op Zwitsers onderzoek naar UMTS-straling, De Stentor, 12th January, Available from:

http://www.stopumts.nl/doc.php/Berichten\%20Nederland/886/ogen_gericht_op_zwitsers_onderzoe k_naar_umts-straling_de_stentor.

van Rongen E (1994) Straling zendmasten geen gevaar voor de gezondheid. Algemeen Dagblad, 5th April. van Uffelen X (2003) TNO: mast voor UMTS schaadt gezondheid. de Volkskrant, 10th January.

VARA (2004) Nationaal Antennebureau: 'UMTS-antennes uit als straling schadelijk is'. Nieuws uit Zembla, Available from: http://redir.vara.nl/tv/zembla/20041202/nieuws.html (not available anymore).

Vasterman P, Scholten O and Ruigrok N (2008) A Model for Evaluating Risk Reporting. The case of UMTS and Fine Particles. European Journal of Communication, 23(3), 319-341.

Vecchia P, Matthes R, Ziegelberger G, et al. (2009) Exposure to high frequency electromagnetic fields, biological effects and health consequences (100 kHz-300 GHz). Oberschleissheim: International Commission on Non-lonizing Radiation Protection, Available from:

http://www.icnirp.org/documents/RFReview.pdf.

Veen M, Gremmen B, te Molder H, et al. (2011) Emergent technologies against the background of everyday life: Discursive psychology as a technology assessment tool. Public Understanding of Science, 20(6), 810-825. 
Venturini T (2010) Diving in magma: how to explore controversies with actor-network theory. Public Understanding of Science, 19(3), 258-273.

Verhoeven I (2009) Burgers tegen beleid. Een analyse van dynamiek in politieke betrokkenheid (Dissertatie). Amsterdam: Aksant.

Vlaamse Regering (2011) Besluit van de Vlaamse Regering van 19 november 2010 tot wijziging van het besluit van de Vlaamse Regering van 1 juni 1995 houdende algemene en sectorale bepalingen inzake milieuhygiëne wat betreft de normering van vast en tijdelijk opgestelde zendantennes voor elektromagnetische golven tussen $10 \mathrm{MHz}$ en $10 \mathrm{GHz}$. Belgisch Staatsblad 2011; 181(13): 1241-9. Available from: http://www.ejustice.just.fgov.be/cgi/api2.pl?|g=nl\&pd=2011-01-13\&numac=2010035951.

Vlaamse Regering (2012) Besluit van de Vlaamse Regering van 16 december 2011 tot wijziging van diverse bepalingen van het besluit van de Vlaamse Regering van 1 juni 1995 houdende algemene en sectorale bepalingen inzake milieuhygiëne en het besluit van de Vlaamse Regering van 19 november 2010 wat betreft de normering van vast en tijdelijk opgestelde zendantennes voor elektromagnetische golven tussen $10 \mathrm{MHz}$ en $10 \mathrm{GHz}$. Belgisch Staatsblad 2012; 182(14): 1688-96.

Vlek C and Stallen PJ (1980) Rational and personal aspects of risk. Acta Psychologica, 45(1-3), 273-300.

VNG (2005) Groeiend verzet tegen plaatsing van antennes. Vereniging van Nederlandse Gemeenten, VNG Magazine, (Week 45).

VNG (2006a) Geen strengere normen UMTS-masten. Vereniging van Nederlandse Gemeenten, VNG Magazine, Available from:

http://www.stopumts.nl/doc.php/Berichten\%20Nederland/1356/geen_strengere_normen_umtsmasten_www.vng.nl, archived at http://www.webcitation.org/6PcAxNx1U.

VNG (2006b) Kamer achter Van Geel. Vereniging van Nederlandse Gemeenten, VNG Magazine, Available from:

http://www.stopumts.nl/doc.php/Berichten\%20Nederland/1359/vng_magazine_over_umts_kamer_ achter_van_geel, archived at http://www.webcitation.org/6Pc9fkcJX.

Von Gleich A (1999) Vorsorgeprinzip. In: Bröchler S, Simonis G, and Sundermann K (eds), Handbuch Technikfolgenabschätzung, Berlin: Editions Sigma, pp. 287-93.

Walker WE, Harremoes P, Rotmans J, et al. (2003) Defining uncertainty: A conceptual basis for uncertainty management in model-based decision-support. Integrated Assessment, 4(1), 5-17.

Walls J, O'Riordan T, Horlick-Jones T, et al. (2005) The meta-governance of risk and new technologies: GM crops and mobile telephones. Journal of Risk Research, 8(7-8), 635-661.

Weg met UMTS (2009a) Homepage. Available from:

http://web.archive.org/web/20090214163315/http://wegmetumts.org/Index.htm (accessed 24 September 2013).

Weg met UMTS (2009b) UMTS = een sluipmoordenaar. Available from:

http://web.archive.org/web/20090214223006/http://wegmetumts.org/actiebeweging.htm (accessed 24 September 2013).

Weingart P (1999) Scientific expertise and political accountability: paradoxes of science in politics. Science and Public Policy, 26(3), 151-161.

Welsh I and Wynne B (2013) Science, Scientism and Imaginaries of Publics in the UK: Passive Objects, Incipient Threats. Science as Culture, 22(4), 540-566.

WHO (1993) Electromagnetic fields (300 Hz - 300 Ghz). Environmental Health Criteria 137, Geneva: United Nations Environment Program, International Radiation Protection Association, World Health Organization, Available from: http://www.inchem.org/documents/ehc/ehc/ehc137.htm.

Wiedemann PM and Schütz H (2005) The precautionary principle and risk perception: experimental studies in the EMF area. Environmental Health Perspectives, 113, 402-405.

Wiedemann PM, Thalmann AT, Grutsch MA, et al. (2006) The impacts of precautionary measures and the disclosure of scientific uncertainty on EMF risk perception and trust. Journal of Risk Research, 9(4), 361-372.

Wilsdon J and Willis R (2004) See-through Science. Why public engagement needs to move upstream. Report, London: DEMOS, Available from: http://www.demos.co.uk/files/Seethroughsciencefinal.pdf. 
Wilsdon J, Wynne B and Stilgoe J (2005) The Public Value of Science. Or how to ensure that science really matters. Report, London: DEMOS, Available from:

http://www.demos.co.uk/files/publicvalueofscience.pdf.

Wittenberg D (1999) Schadelijke zendmasten. NRC Handelsblad, 8th April.

Wolsink M (2000) Wind Power and the NIMBY-myth: institutional capacity and the limited significance of public support. Renewable Energy, 21, 49-64.

WRR (2010) Uncertain Safety: Allocating responsibilities for safety (English version). Amsterdam, The Netherlands: Amsterdam University Press, Available from:

http://www.wrr.nl/fileadmin/en/publicaties/PDF-Rapporten/Uncertain_safety.pdf.

WRR (2012) Vertrouwen in burgers [confidence in citizens]. Amsterdam: Wetenschappelijke Raad voor het regeringsbeleid (The Netherlands Scientific Council for Government Policy), Available from: http://www.wrr.nl/fileadmin/en/publicaties/PDF-samenvattingen/Confidence_in_Citizens.pdf.

Wyatt S and Henwood F (2006) The Best Bones in the Graveyard: Risky Technologies and Risks in Knowledge. In: Timmermann C and Anderson J (eds), Devices and Designs: Medical Innovation in Historical Perspective, Houndmills: Palgrave Macmillan, pp. 231-248.

Wynne B (1989) Frameworks of Rationality in Risk Assessment: towards the testing of naïve sociology. In: Brown J (ed.), Environmental Threats: analysis, perception, management, London: Pinter, pp. 85-103.

Wynne B (1992) Public understanding of science research: new horizons or hall of mirrors? Public Understanding of Science, 1(1), 37-43.

Wynne B (1996) May the Sheep Safely Graze? A Reflexive View on Expert-Lay Knowledge Divide. Risk, Environment and Modernity: Towards a New Ecology, London: Sage.

Wynne B (2006) Public Engagement as a Means of Restoring Public Trust in Science - Hitting the Notes, but Missing the Music? Community Genetics, 9, 211-220.

Wynne B (2008) Elephants in the rooms where public encounter 'science'?: A response to Darrin Durant, 'Accounting for expertise: Wynne and the autonomy of the lay public'. Public Understanding of Science, $17,21-33$.

Wynne B (2010) When doubt becomes a weapon. Nature, 466(7305), 441-442.

Yin RK (1994) Case Study Research: Designs and Methods. Thousand Oaks, California: Sage Publications.

Zienswijze ontwerpontheffing/ontwerpbouwvergunning (2011) Available from: http://www.vroendaal.nl/portal/docs/ZIENSWIJZE_DEFINITIEF.pdf, archived at http://www.webcitation.org/6PW37I2cP (accessed 5 December 2014).

Zwamborn A, Vossen S, van Leersum B, et al. (2003) Effects of Global Communication system radiofrequency fields on Well Being and Cognitive Functions of human beings with and without subjective complaints. Report, TNO Physics and Electronics Laboratory. 



\section{NEDERLANDSE SAMENVATTING}

Aan de plaatsing van infrastructuren voor oude en nieuwe technologieën komt nooit een einde: hoe meer mensen, hoe meer infrastructuur voor afvalbeheer, energieproductie (windenergie, elektriciteit, kernenergie, enz.), industriële activiteiten en communicatietechnologieën (radio, draadloze communicatie, etc.) nodig is. Het komt regelmatig voor dat burgers die geconfronteerd worden met de bouw van een infrastructuur in hun buurt het niet eens zijn met deze beleidsbeslissing en hiertegen ageren. Vaak vinden politici, beleidsmakers en sociale wetenschappers deze reacties moeilijk te begrijpen, vooral als het gaat om technologieën die populair zijn (bijvoorbeeld, masten voor mobiele telefonie) of als 'goed' bestempeld zijn (bijvoorbeeld, windmolens om groene energie te genereren). Inplantingscontroverses over landschapsverandering of ongewenste infrastructuur worden daarom over het algemeen opgevat als ontwrichtend, onaangenaam, uitdagend en een blokkade voor (technologische en economische) vooruitgang. Begrippen als Not In My Backyard (NIMBY) (letterlijk: niet in mijn achtertuin) hebben bijgedragen aan het imago van burgers die protesteren tegen beleidsbeslissingen vanwege irrationele en emotionele zorgen. Vooral wanneer bezorgdheid over mogelijke gezondheidsrisico's een rol speelt, waarvoor er geen duidelijk wetenschappelijk bewijs is, worden de zorgen van burgers weggezet als 'risicopercepties' die ver verwijderd zijn van de wetenschappelijke interpretaties van de zogenaamde échte risico's.

In dit proefschrift stel ik deze typering in vraag aan de hand van casusonderzoek naar de maatschappelijke dynamiek van een bepaald type van controverse: de plaatsing van zendmasten voor mobiele telefonie in Nederland en Vlaanderen (België). In deze dynamiek staan verschillende actoren centraal: de GSM-operatoren die hun masten willen plaatsen, de collectieven van burgers die zich engageren om de plaatsing te voorkomen, netwerken van georganiseerde groeperingen die burgers ondersteunen in hun engagement, gemeenten die te maken krijgen met tegenstrijdige belangen van burgers, nationale beleidsmakers en GSM-operatoren, en wetenschappers die hun kennis beschikbaar maken voor beleidsmakers en andere partijen. Ik vraag me af hoe we de maatschappelijke dynamiek en de mechanismen die verantwoordelijk zijn voor het ontstaan, de voortzetting en de (mogelijke) beëindiging van mastencontroverses kunnen begrijpen? Ik ben vooral geïnteresseerd in de rol van wetenschappelijke kennis en onzekerheden: hoe verschillende actoren in de controverse (burgers, beleidsorganen, wetenschappers) gebruik maken van en voortbouwen op de wetenschappelijke kennis betreffende draadloze communicatietechnologie, en/of deze betwisten of negeren? Ik start mijn onderzoek vanuit de observatie dat gezondheidsrisico's een dominant thema zijn in discussies over deze technologie, en vooral in discussies over het plaatsen van masten. Ik vraag me daarom af waarom, en hoe, draadloze communicatietechnologie is kunnen uitgroeien tot een significant 'gezondheidsri- 
sico'? Ik verken de dynamiek tussen betrokken burgers, verschillende niveaus van besluitvorming, de wetenschappelijke kennis over de gezondheidsrisico's van radiofrequente elektromagnetische velden (RF EMV) en pogingen tot overleg en participatie.

Uit mijn onderzoek komt naar voren dat de opkomst, ondersteuning en beëindiging van controverses over masten opgevat dient te worden als een dynamische wisselwerking tussen burgerbetrokkenheid bij het plaatsen van masten en governance benaderingen van dit engagement. De interactie tussen verschillende niveaus van beleid (gemeentelijk en nationaal niveau) leidde tot een dominante focus op en verankering van gezondheidsrisico's van EMV. Verwijzen naar gezondheidsrisico's werd 1) een gepolitiseerd argument gebruikt door burgers ('de staat moet haar burgers beschermen tegen schade'), 2) een verklarende factor voor de controverses gebruikt door de nationale overheid ('burgerbetrokkenheid ontstaat vanwege de angst voor straling'), en 3) de drijvende kracht van een bepaald beleidskoers (een risicogebaseerde aanpak).

Ik baseer deze bevindingen op een kwalitatieve analyse van 1) verschillende casussen van mastencontroverses in Nederland en Vlaanderen, 2) beleidsprocessen rond mobiele telefonie en mastencontroverses en 3) het ontstaan en bestaan van (kennis)netwerken rond mobiele telefonie. Ik selecteerde 4 Nederlandse en 2 Vlaamse casussen en gebruikten diverse bronnen zoals media-archieven, relevante beleids- en juridische documenten, websites van burgers of groeperingen, interviews met betrokken burgers en lokale actoren (in totaal 46 interviews) en observaties van bijeenkomsten. Ik analyseerde internationale, nationale, regionale en lokale besluitvormingsprocessen (Kamerstukken, persberichten en wetgeving) en mediaberichten rondom het plaatsen van masten door desktop onderzoek van online bronnen en het bijwonen van bijeenkomsten georganiseerd door beleidsactoren. Om de vorming van netwerken, zowel geïnitieerd door burgers (bottom-up) als door beleidsmakers (top-down), te onderzoeken zocht ik online naar websites van lokale, nationale en internationale groeperingen die ageren tegen masten, sprak ik met deze (belangen)groeperingen (die ik grassroots support teams noem) en andere betrokkenen bij een belangrijk Nederlands kennisnetwerk, het Kennisplatform EMV \& Gezondheid (in totaal 11 interviews). Het Kennisplatform is een overheidsinitiatief waarin kennisinstituten (zoals het RIVM), industrie, belangenverenigingen, grassroots support teams en wetenschappers met elkaar in gesprek gaan over EMV en gezondheid. Daarnaast woonde ik bijeenkomsten bij van dit Kennisplatform.

Mijn analyse van de bestaande sociaalwetenschappelijke literatuur over controverses rond masten en publieke zorgen over draadloze communicatietechnologie in hoofdstuk 2 wijst erop dat het huidige academische debat zich vooral richt op de risicopercepties van zogenaamde 'leken', d.w.z. zij die geen wetenschappelijke experts zijn. Dergelijke studies concluderen dat mensen weinig kennis hebben over de werkelijke gezondheidsrisico's van RF EMV en dat er dus behoefte is aan betere risicocommuni- 
catie. Ondanks de mogelijke meerwaarde van goede (risico)communicatie, bekritiseer ik deze studies omdat ze zich vooral op het individu en diens perceptie richten, terwijl burgers in mastencontroverses zich vereniging in groeperingen met een heel andere dynamiek tot gevolg. Daarnaast gaan deze studies ervan uit dat burgers tegen masten zijn omdat ze schrik hebben voor mogelijke gezondheidsrisico's. De studies zijn er dan op gericht om de mate van 'angst' te meten en manieren te zoeken om mensen van het tegendeel te overtuigen. Ik beweer dat deze onderzoekmethode leidt tot nauwe interpretaties van een complex sociaal probleem dat wortels heeft in wetenschap, maar niet noodzakelijkerwijs alleen een kwestie van wetenschap (en het zogenaamd gebrek hieraan) is.

In hoofdstuk 3 bespreek ik burgerengagement of burgerbetrokkenheid bij het plaatsen van masten. Ik typeer de burgers die betrokken zijn bij de plaatsing van een mast als groepen van geëngageerde burgers die het niet eens zijn met een beslissing die hun omgeving aangaat. Ze zijn vaak hoger opgeleid, meer dan gemiddeld geïnteresseerd in de politieke besluitvorming die hun omgeving aangaat en goed ingebed in lokale netwerken (bijvoorbeeld als lokale ondernemer of lid van een buurtplatform). Deze groepen van burgers lijken op wat in de literatuur naar sociale bewegingen bekend staat als 'grassroots' groeperingen: ze zijn verbonden met een buurt, informeel, open, tijdelijk en flexibel. De burgers proberen de mast tegen te houden via de officiele administratieve kanalen van bezwaarschriften en zienswijzen die bij de gemeenten kunnen worden ingediend. Ik noem deze vorm van burgerbetrokkenheid daarom agonistisch: burgers stellen het beleidsproces in vraag, maar doen dit binnen de grenzen van het politieke systeem.

In hun zoektocht naar informatie over masten komen geëngageerde burgers via het internet in contact met tal van websites van groeperingen of individuen die burgers willen bijstaan in hun lokaal engagement tegen masten. Het contact met deze support teams beïnvloedt de lokale burgergroeperingen die zich aan het vormen zijn op verschillende manieren: de websites erkennen het belang van het burgerengagement, ze bieden burgers informatie aan over mogelijke gezondheidsrisico's, ze stellen bepaalde sociale acties voor (bijvoorbeeld contact met de media, bezwaarschriften schrijven, juridische acties ondernemen) en ze schetsen een beeld van een misleidende industrie en overheid. Dergelijke overkoepelende groeperingen die burgers ondersteunen in hun engagement staan in de literatuur rond sociale bewegingen bekend als grassroots support groups. Een belangrijk verschil in mijn casussen is dat deze ondersteunende groeperingen zeer klein zijn (tussen 1 en 5 medewerkers/vrijwilligers) maar via het Internet een enorme grote groep mensen bereiken, daarom spreek ik over teams. Dit is een belangrijke nieuwe ontwikkeling binnen het sociale bewegingen en burgerparticipatie onderzoek.

Er zijn uiteenlopende redenen waarom burgers zich engageren tegen een mast: horizonvervuiling, beschadiging van de omringende natuur, ondeugdelijk besluitvormingsproces door een gebrek aan informatie en inspraak over de geplande locaties, 
mogelijke waardedaling van omliggende huizen en gezondheidsrisico's door straling van masten. In iedere onderzochte casus is het vooral een gebrek aan informatie en inspraak vanuit de lokale overheid dat kwaad bloed zet. Ondanks deze verscheidenheid beschouwen burgers het argument van mogelijke gezondheidsrisico's als erg overtuigend in hun betoog. Het garandeert sympathie omdat men op de bres gaat staan voor de gezondheid van de medemens. Met andere woorden: het gezondheidsargument creëert een collectief belang. Daarnaast past het ook in andere nietwetenschappelijke vormen van kennis waarmee mensen in contact komen, zoals persoonlijke en collectieve ervaringen met ziektes die toegewijd worden aan EMV. Kortom, burgers gebruiken de taal van 'risico's' als een politiek instrument om hun engagement te versterken. Ze beschouwen het als een argument dat niet genegeerd kan worden door de industrie, overheid en wetenschappers.

Toch ziet de overheid burgerengagement - of 'publiek verzet tegen masten' zoals telecom operatoren het vaak beschrijven - vooral als een probleem van gebrek aan kennis over gezondheidsrisico's. In hoofdstuk 4 beschrijf ik hoe deze visie sinds het begin van de jaren 2000 enerzijds resulteerde in het opzetten van onderzoeksprogramma's naar mogelijke gezondheidsrisico's van masten en anderzijds in betere risicocommunicatie naar burgers. Deze risico-gebaseerde benadering bood een verklaring voor de controverses, namelijk het publiek had een verkeerd beeld van de risico's en het bood oplossingen, namelijk investeren in meer onderzoek en beter uitleggen dat er weinig risico's zijn. De communicatiestrategie van de rijksoverheid bestond uit het opzetten van een informatiepunt, het Antennebureau, dat als belangrijke taak had om informatieavonden te verzorgen in buurten waar een mast gepland stond. De communicatieactiviteiten van het Antennebureau berustten op twee aannames: 1) maar een beperkt deel van de Nederlandse bevolking had informatie over masten en EMV nodig, in het bijzonder burgers die geconfronteerd werden met het plaatsen van een mast en burgers die direct vragen stelden aan gemeenteambtenaren, GGD'en en mobiele operatoren en 2) dat beperkte publiek ontbrak het aan duidelijke wetenschappelijk informatie over gezondheidsrisico's. De tweede aanname staat bekend als het 'deficit model of public understanding of science' en wordt al jaren bekritiseerd door sociale wetenschappers, maar blijft desondanks een hardnekkig geloof bij veel beleidsmakers en communicatiespecialisten.

Hoofdstuk 5 gaat dieper in op de risico-gebaseerde beleidsaanpak van de rijksoverheid. Door deze aanpak veranderde het probleem van masten van een politieke kwestie met veel onzekerheden in een enge wetenschappelijke vraag die beantwoord diende te worden door experts. Deze benadering was geworteld in 1) de ontkenning van de legitimiteit van inspraak van burgers bij het plaatsen van masten; 2) de aanname dat mastencontroverses het gevolg waren van ongegronde vrees voor gezondheidsrisico's van de antennes; en 3) de aanname dat mastencontroverses konden worden opgelost door te investeren in wetenschappelijke kennis over de gezondheidsrisico's en risicocommunicatie. 'Gezondheidseffecten van EMV' werd op deze 
manier hét centrale thema in nationale discussies over masten. Wetenschap werd ingezet als een rechter die als enige kon beslissen over de legitimiteit van de verdere uitrol van mobiele telefonie. Wetenschappers konden deze zekerheid echter niet bieden en hun studies (en soms zijzelf) kwamen hevig ter discussie te staan omwille van de onzekerheden in de wetenschappelijke kennis over EMV en gezondheidseffecten en vermeende belangenverstrengeling.

De overheid probeerde deze situatie op te lossen door meer geld vrij te maken voor onderzoek en door het Kennisplatform EMV \& Gezondheid op te richten om de wetenschappelijke expertise op het gebied van EMV en gezondheid te bundelen. Daarnaast werd er ook een Klankbordgroep opgericht binnen het Kennisplatform, waarin wetenschappers, beleidsmakers, professionals, industrie en maatschappelijke organisaties (met name de grassroots support teams) samen kwamen om mobiele telefonie te bespreken. Ondanks de insteek van het platform om 'de stem van de maatschappij' te horen, waren het vooral maatschappelijke actoren die zich ernstig zorgen maakten over gezondheidsrisico's die de discussies domineerden. De uitnodiging van deze actoren als vertegenwoordigers van 'de maatschappij' leidde tot een verdere vernauwing van de maatschappelijke discussie rond masten tot een gezondheidsvraag. Samen met de initiële reacties van de rijksoverheid (meer onderzoek en meer risicocommunicatie) leidde het platform er ook toe dat de risicoframing van masten ('maken ze je ziek of niet?') versterkt werd, en dat de zorgen van burgers op lokaal niveau niet eens meer aan bod kwamen. Deze wanverhouding tussen de lokale en nationale niveaus droeg bij tot de opkomst en het voortbestaan van mastencontroverses.

In hoofdstuk 6, ten slotte, plaats ik mijn onderzoek in een breder academisch en politiek debat over hoe de maatschappij moet omgaan met (nieuwe) technologieën. Mijn analyse laat een aantal belangrijke dynamieken zien die verklaren waarom controverses over nieuwe technologieën en/of plaatsingsconflicten ontstaan:

Het gebrek aan betrokkenheid van omwonenden bij beslissingen over het plaatsen van technologieën, bijvoorbeeld door inspraak bij de locatiekeuze

Het gebrek aan erkenning van de sociale dynamiek van lokale buurten die bepalend is voor de manier waarop op de plaatsing van een technologie wordt gereageerd, zoals het belang van een lokale cultuur en de ervaringen met eerdere conflicten over ruimtelijke ordening

Het opdringen van een nationaal beleid zonder de zorgen en belangen van lokale overheden in acht te nemen, en zonder lokale overheden een duidelijke rol te geven in de besluitvorming 
Het bestaan van een sterk netwerk van contra-expertise dat erg toegankelijk is via het Internet, bestaande uit actieve burgers, grassroots support teams en belangenverenigingen die onzekerheden politiseren en onderliggende waarden en belangen van wetenschappelijke kennis belichten

Het exclusief framen van publieke zaken in wetenschappelijke termen door beleidsmakers - zelfs wanneer het maatschappelijke debat divers is, er conflicterende belangen zijn en belangrijke democratische thema's aan bod komen

De uitvoering van een risico-gebaseerd beleidsproces dat zorgen over gezondheidsrisico's en voorzorgsmaatregelen eenvoudigweg verwerpt door wetenschappelijke studies en wetenschappelijke raden te gebruiken als scheidsrechters die bepalen wat een aanvaardbaar en onaanvaardbaar risico is 


\section{VALORISATIE ADDENDUM}

\section{Maatschappelijke relevantie}

De wetenschappelijke inzichten uit dit proefschrift zijn van waarde in het maatschappelijke debat over de omgang met mogelijke risico's en onzekerheden van nieuwe technologieën en innovaties. Ondanks het feit dat we leven in een kennissamenleving waarin innovatie essentieel is, is het anderzijds ook zo dat innovaties onzekerheid creëren over mogelijke risico's. Deze risico's zijn niet altijd op een eenvoudige manier te berekenen met de huidige technische en wetenschappelijke middelen. De laatste jaren is er heel wat onrust geweest over innovaties, denk aan genetisch gemanipuleerd voedsel, nanotechnologie of schaliegas. Het vertrouwen in de betrouwbaarheid, competentie en doelgerichtheid van wetenschappers en beleidsmakers is de afgelopen jaren danig geschaad. De governance van innovaties is daarom een enorme uitdaging voor onze democratie.

Dit proefschrift is van maatschappelijk belang omdat het een grondige reflectie is op hoe onze genetwerkte maatschappij met een modern risico-vraagstuk omgaat. Dit boek biedt inzichten voor beleidsmakers, wetenschappers en stakeholders in het debat over mobiele telefonie en meer algemeen over innovaties. Een belangrijk inzicht gaat over het benutten van wetenschappelijke kennis om een complex sociaal probleem op te lossen dat wel wortels heeft in wetenschap, maar niet noodzakelijkerwijs alleen een kwestie van wetenschap (en het gebrek aan kennis) is. Bovendien is dit boek interessant voor een ieder die gefascineerd is door de rol van wetenschap en technologie in onze kennissamenleving. Hieronder verduidelijk ik 1) hoe mijn onderzoek maatschappelijke relevant is en 2 ) wat ik ondernomen heb om deze relevantie publiekelijk te maken.

1) Het onderzoek in dit proefschrift is maatschappelijk relevant omdat het bijdraagt aan het beantwoorden van een belangrijke vraag waar de maatschappij regelmatig mee geconfronteerd wordt: hoe moeten we omgaan met mogelijke risico's van technologische en wetenschappelijke innovaties? Dat deze vraag hoog op de wetenschappelijke agenda staat bleek toen Marjolein van Asselt, Tessa Fox en ik in 2011 een KNAW-prijs wonnen voor het inzenden van deze vraag ter gelegenheid van het vervolledigen van de KNAW-wetenschapsagenda. Mijn onderzoek stimuleert het denken over en beantwoorden van deze vraag door te beargumenteren dat bij het omgaan met moderne risicovraagstukken een rationele benadering waarin een technische en/of natuurwetenschappelijke vraag centraal komt te staan geen recht doet aan de maatschappelijke complexiteit van deze fenomenen. Waarmee ik niet wil zeggen dat natuurwetenschappen geen belangrijke rol kunnen spelen bij het beantwoorden van dergelijke beleidsvragen. Het probleem is dat wetenschappers meestal geen duidelijk 
antwoord kunnen geven aangezien er veel onzekerheden zijn. Zijn er gezondheidsrisico's bij het plaatsen van masten voor omwonenden? Kan je kanker krijgen van mobiel telefoneren? Er is geen bewijs voor schadelijkheid, maar het tegendeel kan ook niet bewezen worden. Toch wordt er nog steeds verwacht dat wetenschap altijd alle antwoorden heeft. Dit leidt tot situaties waarin wetenschap een te belangrijke rol krijgt toebedeeld als scheidsrechter die over de toekomst van een technologische ontwikkeling beslist. Ik pleit ervoor dat onzekere en omstreden risicovraagstukken niet als puur technische kwesties behandeld dienen te worden, maar als politieke vraagstukken waarin onzekerheid erkend wordt.

Dit is een belangrijke boodschap voor beleidsmakers. Als zij beslissingen willen nemen die zowel wetenschappelijk als democratisch verantwoord zijn zullen ze 'het probleem' van onzekerheden niet kunnen verschuiven naar wetenschappers. Dit is niet enkel kwalijk voor beleidsmakers, maar ook voor wetenschappers. Omgaan met onzekerheden eist een democratisch proces waarin alle mogelijke perspectieven op het probleem geformuleerd én meegenomen worden. Ondanks het feit dat dit proces complex, moeilijk en soms zelfs onaangenaam is, en het tevens nog in de kinderschoenen staat, lijkt het de uitgelezen manier om maatschappelijke polarisatie te voorkomen. Daarnaast laat dit proefschrift zien dat burgers graag betrokken willen worden bij lokale beleidsbeslissingen. Het gebrek aan inspraak bij het plaatsen van masten was in al mijn casussen een belangrijke reden om te starten met burgerengagement. Het is niet omdat burgers als consumenten een nieuwe technologie omarmen, dat ze de plaatsing ervan als geëngageerde bewoners van een wijk onproblematisch vinden. Dit is een 'positieve' bevinding die - wanneer serieus genomen door beleidsmakers - zou kunnen leiden tot minder plaatsingsconflicten.

(2) Hoe heb ik ervoor gezorgd dat de relevantie van mijn onderzoek bekend werd? Onderzoek doen naar een hedendaags en controversieel onderwerp betekent dat je zelf - bewust of onbewust - een actor wordt in de discussie. Door het interviewen van mensen en door mijn aanwezigheid bij bepaalde bijeenkomsten beïnvloedde ik de discussie. Zelfs als ik niets zei, of enkel interviewde zonder mijn eigen mening te verkondigen, deden mijn aanwezigheid of mijn vragen mensen nadenken over hun eigen rol. Sommige burgers werden bijvoorbeeld versterkt in hun geloof dat ze iets belangrijks aan het doen waren, puur omdat een wetenschapper (helemaal uit Maastricht) kwam om hun visie te horen. Als etnograaf heb je dus altijd enigszins invloed op het thema dat je onderzoekt.

Daarnaast heb ik mij ook actiever ingezet om mijn onderzoeksresultaten publiekelijk te maken. Ik richtte me vooral op het publiek van beleidsmakers en professionals, door mee te werken aan een project van het Rathenau Instituut over betrouwbare wetenschap (Blankesteijn et al., 2014). Op basis van casusonderzoek naar publieke controverses rond wetenschap en beleid (waaronder mijn casus over mobiele telefonie) deed het Rathenau Instituut aanbevelingen aan beleidsmakers en wetenschap- 
pers voor de omgang met zulke controverses. Ik schreef ook twee artikelen voor het Magazine Nationale Veiligheid en Crisisbeheersing (Hermans and van Asselt, 2012, 2014), een tweemaandelijkse uitgave van de Nationaal Coördinator Terrorismebestrijding en Veiligheid van het ministerie van Veiligheid en Justitie gericht op bestuurders en professionals. Daarnaast publiceerde ik een artikel in het Nederlandstalig wetenschappelijk tijdschrift Bestuurskunde (Hermans et al., 2014). In 2011 kregen Marjolein van Asselt, Tessa Fox en ik de KNAW-prijs voor het inzenden van de $50^{\text {ste }}$ vraag van de KNAW-wetenschapsagenda. Hiermee belichtten we het belang van onderzoek naar risicovraagstukken en het interdisciplinaire veld van risico governance.

Daarnaast heb ik ook geïntervenieerd in een mastencontroverse in de buurt. In 2012 kwam ik in contact met een groep burgers die ontevreden waren over hoe hun gemeente omging met de toekomstige plannen om een school vlak naast een mast voor mobiele telefonie te bouwen. Bezorgde ouders hadden aangeklopt bij deze groep burgers, bekend als de Stichting de Groene Sporenwolf die al enkele jaren opkwam voor de belangen van hun omgeving. De stichting wilde graag mijn visie horen. Tijdens een gesprek met de stichting gaf ik mijn inzichten over lokale mastcontroverses om een nuchtere bijdrage te kunnen leveren. Tijdens dit gesprek kwamen verschillende bevindingen naar boven: dat een gang naar de rechter om de mast weg te krijgen op basis van gezondheidsrisico's vrijwel kansloos was, dat wetenschap onmogelijk kan bewijzen dat iets $100 \%$ veilig is, hoe onderzoek naar EMV en gezondheidseffecten werkt en wat de wetenschappelijke criteria zijn waarop een studie wordt beoordeeld. Vervolgens ging ik in op wat de stichting kon betekenen voor de ouders die ongerust waren. Ik vertelde dat het belangrijk was om de ongerustheid van mensen serieus te nemen, om te communiceren over onzekerheden en om mensen op hun eigen verantwoordelijkheid en keuzemogelijkheid te wijzen (bijvoorbeeld beperken van persoonlijk gebruik van mobieltje of Wi-Fi). Op basis van dit gesprek veranderde de stichting van strategie: ze wilden niet langer een inhoudelijke discussie voeren over de schadelijkheid van de mast, omdat die enkel tot polarisatie zou leiden, maar verlegde de koers naar meer aandacht voor voorzorgsmaatregelen in de school (zoals beleid rond mobieltjes en Wi-Fi) en betere informatievoorziening over de risico's en onzekerheden. Ze publiceerden hierover in de lokale kranten. Op hun verzoek had ik een paar weken later ook een gesprek met de directeur van de basisschool waarin ik inging op het belang van goede risicocommunicatie.

Mijn onderzoek heeft tot dusver al voor enige verdieping gezorgd in een erg moeizame discussie. Ik hoop dat ik dit in de toekomst nog verder kan doen. 



\section{CURRICULUM VITAE}

Marijke Hermans (Bree, 1982) studied a BA in Business Communication at Xios Hogeschool in Hasselt, Belgium and a BA in Arts \& Culture at Maastricht University, the Netherlands. She spent a semester as an Erasmus student at Sciences Po in Lille, France. She earned a Master of Philosophy degree in the Cultures of Arts, Science and Technology program at Maastricht University in 2008. She was an intern junior researcher during her master studies at SPRU (Science and Policy Research Unit) at Sussex University, Brighton. Through the work of Prof. Erik Millstone, her interest grew in the analysis of contemporary questions on the interface of science and policy. After her studies, she worked as a junior researcher on the role of uncertainties in scientific evaluations. In September 2009, she started her PhD research on the societal dynamics of the controversies around the siting of mobile phone masts. As part of her PhD work, she taught courses and was enrolled in the graduate training program of the Netherlands Graduate School of Science, Technology and Modern Culture (WTMC). Together with Marjolein van Asselt and Tessa Fox, she was awarded 'De vijftigste vraag van de Nederlandse wetenschapsagenda' (50th question of the Dutch science agenda) by the Royal Dutch Academy of Sciences (KNAW). She has now taken up a postdoc position at the Faculty of Arts and Social Sciences at Maastricht University, focusing on risk governance of uncertain and contested policy issues. 
This book offers a contribution to answering one of the most pressing questions of our knowledge society: how do we deal with possible risks and uncertainties from new technologies? Engaging with risks traces the governance of one such complex, controversial and multi-actor risk question: concerns about health risks from the siting of mobile phone masts in the Netherlands and Flanders (Belgium). Based on multi-method social scientific research, the book moves beyond the portrayal of citizen engagement in siting conflicts as disruptive, hostile and frustrating and offers an analysis of siting controversies as healthy signs of democracy. This book is relevant to researchers, policy makers, scientists and anyone interested in the dynamic relationship between citizens, science and policy in decision making about risks.

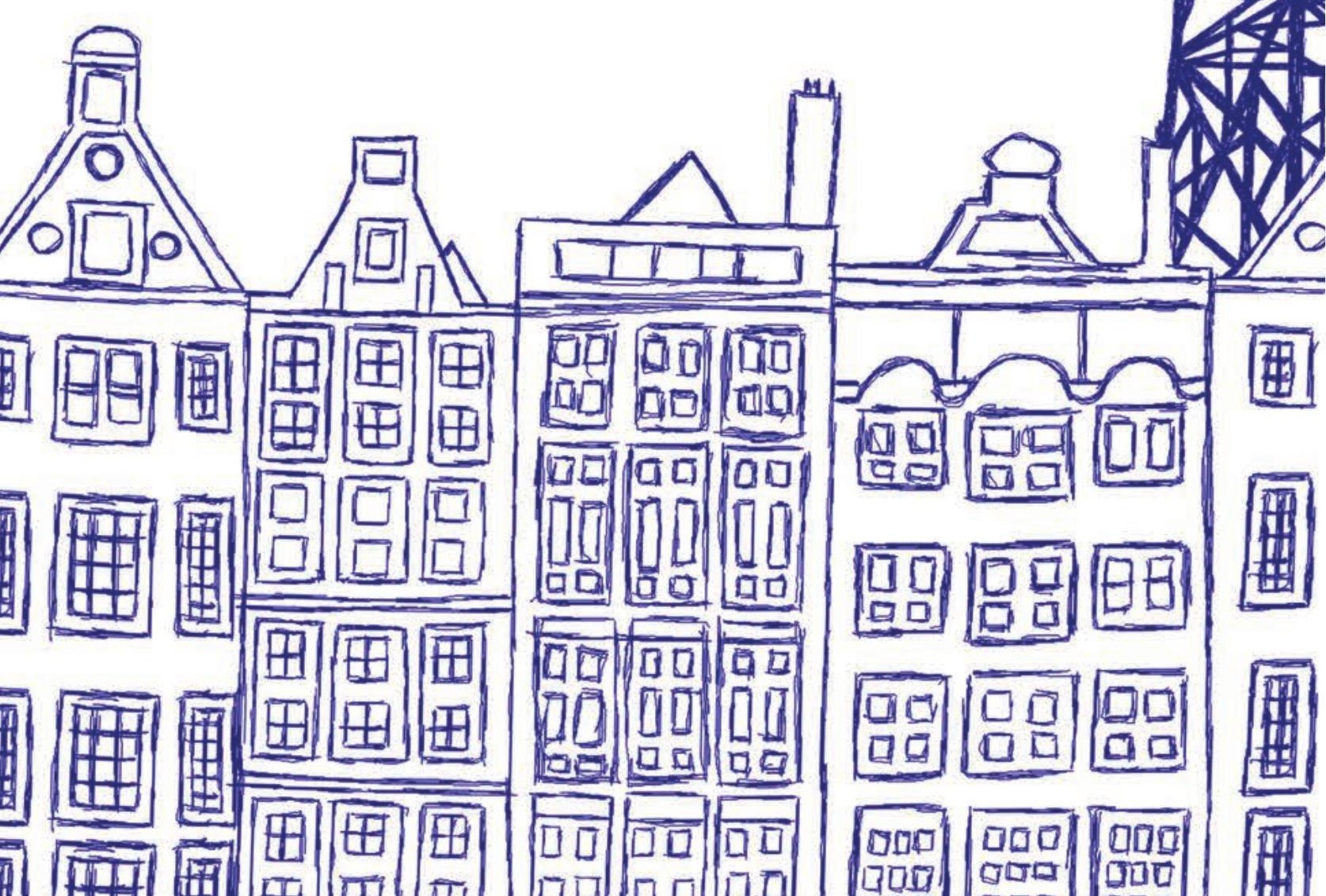

